SZEGEDI TUDOMÁNYEGYETEM

Természettudományi és Informatikai Kar

Földtudományok Doktori Iskola

Természeti Földrajzi és Geoinformatikai Tanszék

\title{
HULLÁMTÉRI AKKUMULÁCIÓ ÉS AZ AZT BEFOLYÁSOLÓ TÉNYEZŐK VIZSGÁLATA AZ ALSÓ-TISZÁN
}

Doktori (PhD) értekezés

NAGY JUDIT

Témavezető:

Dr. Kiss Tímea

Egyetemi docens 


\section{Tartalomjegyzék}

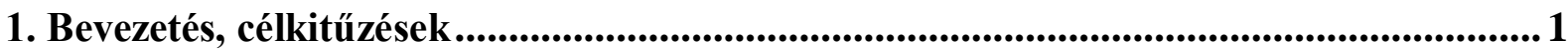

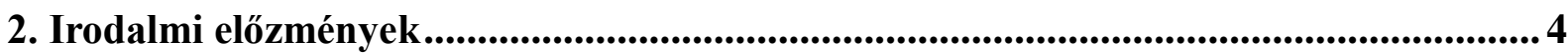

2.1. A hullámtér általános feltöltődése...............................................................4

2.1.1. A hullámterek feltöltödésének mértéke ...................................................................................... 4

2.1.2. Az árterek feltöltődését befolyásoló tényezök ........................................................................ 12

2.1.3. A hullámtéri feltöltődés vizsgálatának lehetséges módszerei .................................... 19

2.2. A feltöltődés kitüntetett helyei: a folyóhátak és az övzátonyok ...........................23

2.2.1. A folyóhátak épülése és a fejlödésüket befolyásoló tényezök .................................... 24

2.2.2. Az övzátonyok kialakulása és a fejlödésüket befolyásoló tényezök .............................. 27

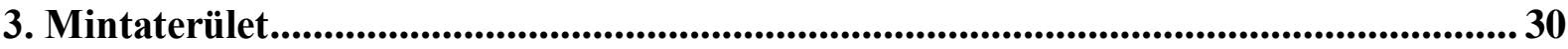

3.1. A Tisza általános hidrológiai jellemzői ...................................................... 30

3.1.1. A Tisza magyarországi szakaszának általános hidrológiai és morfológiai jellemzői 30

3.1.2. Az Alsó-Tisza és árterének morfológiai és hidrológiai jellemzői.............................. 33

3.2. Az ármentesítési és szabályozási munkálatok és következményei .......................... 36

3.2.1. A 19-21. századi meder- és ártér-szabályozási munkálatok a Tisza magyarországi

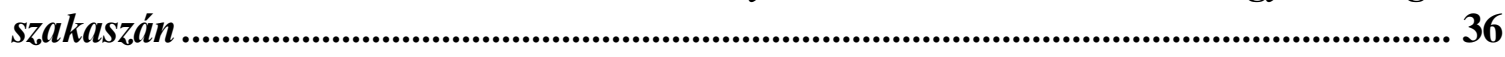

3.2.2. Ármentesítési és mederszabályozási munkálatok és azok következményei az Alsó-

Tisza mentén............................................................................................................... 38

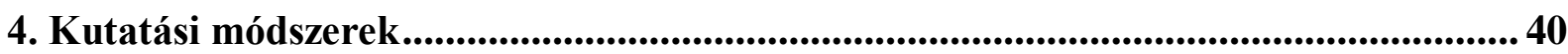

4.1. A hullámtér-feltöltődés mértékének meghatározása ...................................... 40

4.2. A folyóhátak vizsgálata ............................................................................ 42

4.3. Az övzátonyok vizsgálata ............................................................................. 44

4.4. A hullámtér feltöltődését, a folyóhátak és az övzátonyok fejlődését befolyásoló tényezők ..................................................................................................................................... 45

4.4.1. A hullámtér és a kanyarulatok paramétereinek meghatározása.............................. 45

4.4.2. Felszínboritás és növényzeti érdesség hosszú távú változása .................................. 47

4.4.3. Az invazív gyalogakác hatása a növényzeti érdességre............................................. 47

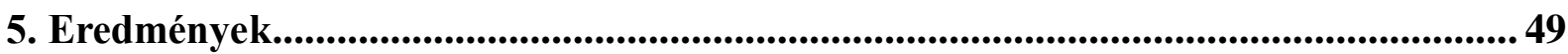

5.1. A hullámtér feltöltődésének jellemzői és a folyamatot befolyásoló tényezők ........ 49

5.1.1. A felhalmozódott hordalék mennyisége és térbeli jellemzöi ........................................ 49

5.1.2. A feltöltödést befolyásoló tényezök vizsgálata ................................................................ 53

5.1.3. A hullámtér vízvezetö-képességének csökkenése ................................................... 67

5.2. A vertikális feltöltődés kiemelt helye: a folyóhátak fejlődése ............................69

5.2.1. A kanyarulatok csoportjai fejlettségük alapján.......................................................... 69

5.2.2. A folyóhátak általános alaktani jellemözi és fejlödésük üteme ................................ 71

5.2.3. A folyóhátak magasságát befolyásoló tényezök ........................................................ 73

5.2.4. A folyóhátak szélességét befolyásoló tényezők .............................................................. 76

5.2.5. A folyóhátak épülésének ütemét befolyásoló tényezök ................................................ 79 
5.2.6. A folyóhátak fejlödését befolyásoló tényezők összevetése ........................................... 80

5.2.7. A folyóhátak és az árvizek magassága közötti kapcsolat ........................................... 81

5.2.8. A folyóhátak szemcseösszetételi vizsgálata ................................................................. 82

5.3. Horizontális feltöltődés kiemelt helye a kanyarulatok belső ívén: az övzátonyok fejlödése ........................................................................................................................ 86

5.3.1. Az övzátony-sorok formálódásának alapvetö jellemzői ............................................ 87

5.3.2. Kanyarulatvándorlási típusok az Alsó-Tisza mentén................................................ 94

5.3.3. A partelmozdulás üteme az Alsó-Tiszán .............................................................................. 95

5.3.4. Övzátony-sorok típusai az, Alsó-Tiszán................................................................96

5.3.5. Az egyes övzátonyok magasságának és szélességének jellemzői ................................ 99

5.3.6. Az övzátonyok méretét befolyásoló tényezök .................................................................. 102

5.3.7. Az övzátony-sorokkal szemben formálódó folyóhátak morfológiai tulajdonságai.... 105

5.3.8. Az övzátonyok és árvizek magassága közötti kapcsolat ............................................. 108

6. Összefoglalás ................................................................................................... 110

6.1. A hullámtéri feltöltődés általános jellemzői és a folyamatot befolyásoló tényezők vizsgálatának eredményei ................................................................................. 110

6.2. A folyóhátak vizsgálatának eredményei ..................................................... 113

6.3. Az övzátonyok vizsgálatának eredményei ........................................................ 115

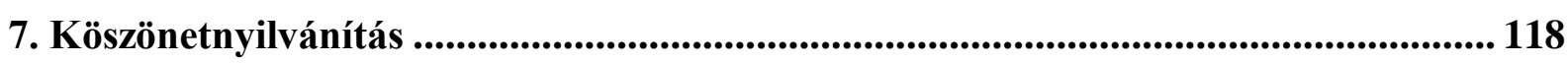

8. Irodalomjegyzék......................................................................................................... 119

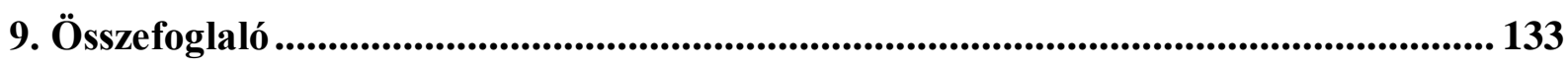

10. Summary ............................................................................................................................ 139

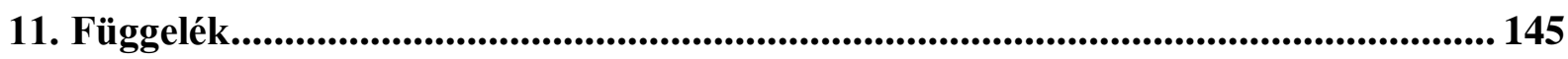




\section{Bevezetés, célkitüzések}

A 19. századi ármentesítési és mederszabályozási munkálatok jelentősen megbontották a folyók természetes egyensúlyi állapotát. A Tisza vízrendszerében az árvízvédelmi töltések kiépítése következtében a korábban $5-10 \mathrm{~km}$ széles ártérre kiöntő árvizek az 1-4 km szélességüre lecsökkentett hullámtéren vonulhatnak le (Török 2000). A folyó által szállított lebegtetett hordalékmennyiség azonban nem csökkent (Jakucs 1982), sőt, a kanyarulatátvágások következtében megnőtt esés megnövelte a folyó munkavégző képességét, amely időlegesen és lokálisan jelentősen megnövekedett hordalékmennyiséget eredményezett. Ez a nagy mennyiségü hordalék az árvizek alkalmával, a jóval szükebb hullámtéri területen kezdett felhalmozódni, ami a szabályozási munkálatok egy addig nem várt következménye volt (Károlyi 1960). Az eredetileg 0,02-0,05 cm/év ütemü természetes ártér-feltöltődés (Félegyházi 2008) átlagosan 0,5-1 cm/évre gyorsult (Nagy et al. 2001, Sándor és Kiss 2006a, 2007). A hordalék intenzív felhalmozódása árvízvédelmi szempontból jelentős problémát okozhat, hiszen az árvizek levezetésére rendelkezésre álló hullámtéri térfogat csökkenését eredményezi (Jakucs 1982, Nagy et al. 2001, Vágás 2001). A megnövekedett árvízi kockázathoz hozzájárul az egyre szélsőségesebbé váló vízjárás is. A 20. század vége óta számos rekord árvíz vonult végig a Tiszán, 1998 és 2006 között a folyó egy-egy szakaszán legalább egyszer megdőlt az addigi legnagyobb vízállás. Például, az 1970-es árvíz szintje (Szeged: $960 \mathrm{~cm}$ ) 2000-ben Szolnokon $81 \mathrm{~cm}-\mathrm{rel}$, 2006-ban Mindszentnél pedig $102 \mathrm{~cm}-\mathrm{rel}$ dőlt meg. Ugyanakkor az elmúlt évtizedben gyakorlatilag alig lépett ki a Tisza a medréből.

$\mathrm{Az}$ árvízi kockázat növekedése persze nem csak az intenzívebb hullámtéri feltöltődés eredménye, szerepe lehet benne például a klímaváltozás okozta szélsőséges csapadékeloszlásnak (Szlávik 2000), a felszínborítás megváltozásának (Jakucs 1982, Konecsny 2000, Lóki et al. 2004), és a meder szükülésének is (Fiala és Kiss 2005, 2006, Kiss et al. 2018a). Azonban a hullámtér vízvezetö-képességének csökkenése nagyban hozzájárulhat ahhoz, hogy a vízgyüjtőről érkező, és a hullámtéren és a mederben levonuló árvíz egyre magasabban tetőzik a vízhozamok növekedése nélkül (Kiss et al. 2019a), miközben egyre tartósabbá is válik a romló vízvezetés miatt.

A hullámtér feltöltődése számos vízgyüjtő-szinten ható tényező (pl. a vízgyüjtő domborzata, alakja, geológiai felépítése, felszínborítása, valamint a lefolyási viszonyai), illetve lokálisan, a hullámtér adott szakaszán ható tényezők (pl. hullámtér-szélesség, kanyarulatok alaktani jellemzői, felszínborítás) együttes eredménye (Chorley et al. 1985, Nanson és Croke 1992). Az intenzív hordalék-felhalmozódás akadályozza az árvizek hatékony levonulását, így ennek megfelelő biztosítása szempontjából nélkülözhetetlen a hordalék akkumulációját befolyásoló tényezők pontos ismerete és vizsgálata.

A hullámtéri feltöltődés kitüntetett helyei a part mentén húzódó folyóhátak és övzátonyok (Wolman és Leopold 1957). Míg a folyóhátakon a vertikális feltöltődés dominál, addig az övzátonyok horizontálisan és vertikálisan is töltődhetnek. Ezek átmeneti formákat képeznek a meder és a hullámtér között, és intenzív feltöltődésük révén jelentősen befolyásolhatják a hullámtérre kilépő víz áramlási viszonyait (Happ et al. 1940, Brierley et al. 1997, Nagy et al. 2001), ennél fogva pedig jelentős hatással vannak a hullámtér vízszállítóképességére (Zwoliński 1992, Kozák és Rátky 1999). A folyóhátak és övzátonyok hosszú távú fejlődése, a formálódásukat befolyásoló tényezők, illetve az, hogy milyen mértékben tükrözik a vízrendszerben bekövetkezett változásokat csak kevésbé kutatott (Brierley et al. 1997, Strick et al. 2018, Kiss et al. 2018ab, Kiss et al. 2019b).

A hazai szakirodalom meglehetősen részletesen foglalkozott a magyarországi folyók mentén zajló hosszú- és rövidtávú hullámtéri feltöltődés vizsgálatával. A legelső hazai kutatások a feltöltődés hosszú távú változását vizsgálták. Ezek még elsősorban becslésen alapultak (Károlyi 1960, Jakucs 1982), majd a technológia fejlödésével megjelentek a pontosabb mérések is. Fúrásszelvények segítségével pollenanalitikai (Oroszi 2009, Kiss et al. 2011), nehézfém (Nagy et al. 2001, Sándor és Kiss 2006a, Braun et al. 2010), radioaktív 
anyagok (Nagy et al. 2001, Dezső et al. 2009), illetve szintjelző talajrétegek (Balogh et al. 2005) segítségével határozták meg a feltöltődés mértékét. A számítógépes technika fejlődésével megjelentek a számítógépes modellek (Koncsos és Kozma 2007), illetve a digitális domborzatmodell (DDM) alapján történő kutatások (Gábris et al. 2002, Vass et al. 2009a, Kiss et al. 2011), amely utóbbiak az aktív hullámtéri felszín és a mentett ártéri területek magasságkülönbsége alapján határozták meg az ármentesítések óta felhalmozódott hordalék mennyiségét. Az 1998-2006-os árvizek pedig arra sarkallták a kutatókat, hogy egyegy árvízi esemény után lerakódó hordalék vastagságát is mérjék (Kiss és Fejes 2000, Kiss et al. 2002, Gönczy és Molnár 2004, Sándor és Kiss 2006a, Vass 2007, Vass et al. 2009b), amelyek segítségével a felhalmozódás térbeli mintázata vált vizsgálhatóvá.

Ezek a kutatások azonban többnyire pontszerü méréseken alapultak, illetve csak egyegy rövidebb szakaszon vizsgálták a feltöltődést, és ezeket az eredményeket általánosították hosszabb folyószakaszokra. Ráadásul leginkább a hordalék felhalmozódásának térbeli mintázatával foglalkoztak, és csupán néhány kutatás érintette a felhalmozódást befolyásoló tényezők vizsgálatát (Borsy 1972, Kozák és Rátky 1999, Nagy et al. 2001, Gábris et al. 2002, Kiss et al. 2002, Rátky és Farkas 2003, Sándor és Kiss 2007, Kiss et al. 2011).

Kutatásom alapvető célja az árvízvédelmi töltések megépítése óta felhalmozódott hordalék mennyiségének meghatározása a teljes Alsó-Tisza mentén, azaz a feltöltődés mértékének megadása nem pontszerü mérési adatokon alapulva. Mivel a feltöltődés mértékét nagyobb területen értékelem, célom annak vizsgálata is, hogy a hordalék-felhalmozódást az adott folyószakaszon milyen tényezök befolyásolják. Mivel a feltöltődés kitüntetett helyei a folyóhátak és az övzátonyok (Sándor 2011), ezért ezen formák fejlődését kiemelten vizsgálom. Mivel a hullámtéri feltöltődés meglehetősen összetett folyamat, így a dolgozatom megírása során a következő föbb célokat tüztem ki.

\section{A hullámtér egészén felhalmozódott hordalék mennyiségének és az azt befolyásoló tényezőknek a vizsgálata}

Célul tüztem ki a hullámtéren felhalmozódott hordalék vastagságának és térfogatának a teljes Alsó-Tisza mentén (Csongrád és a szerb-magyar országhatár között) történő vizsgálatát nagy felbontású LiDAR felmérés alapján készített digitális domborzatmodell (DDM) segítségével. A hullámtér egészének feltöltődése kapcsán a következő kutatási kérdéseket tettem fel:

- Mi jellemzi a hullámtér $90 \mathrm{~km}$ hosszú szakaszán a feltöltődés vastagságát és térfogatát?

- Az ármentesítési munkálatok óta felhalmozódott hordalék mennyivel csökkentette az árvizek levezetésére szolgáló hullámtéri térfogatot, és mely szakaszokon a legjelentősebb a hullámtér vízvezető-képességének csökkenése?

A hordalék felhalmozódását befolyásoló tényezők között vannak olyanok (pl. hullámtérszélesség), amelyek a hullámtér teljes szélességében, míg vannak, amelyek (pl. kanyarulati paraméterek) csak a part menti szükebb sávban fejtik ki hatásukat. A teljes hullámtéren zajló feltöltődést befolyásoló tényezők vizsgálata kapcsán a következő kérdésekre keresem a választ:

- A változó szélességü Alsó-Tisza mentén milyen jellegü a kapcsolat a hullámtérszélesség és a felhalmozódott hordalék vastagsága, illetve térfogata között?

- A beömlő mellékfolyók (Hármas-Körös és Maros) milyen hatással vannak a feltöltődésre, illetve a torkolatuktól alvízi irányban milyen távolságig érvényesül a hatásuk?

A kutatás során kiemelten kezeltem a hullámtéri növényzet hatását, mivel jelentős hatást gyakorolhat a hullámtér feltöltődésére, ugyanis az ármentesítési munkálatok óta a hullámtér felszínborítása jelentős változásokon ment keresztül, ráadásul a 20. század második felében eröteljes terjedésnek indultak a nem őshonos, invazív növényfajok, amelyek közül 
legnagyobb problémát a mintaterületen a gyalogakác (Amorpha fruticosa) okozza. A növényzet hatásának vizsgálata során a következő célokat tüztem ki:

- Az 1700-as évek óta hogyan változott az Alsó-Tisza hullámterén a felszínborítás, és ezzel együtt hogyan változott a felszín növényzeti érdessége?

- Az invazív gyalogakác milyen mértékben terjedt el az egyes felszínborítási kategóriákban, és jelenléte milyen mértékben növeli a hullámtéri növényzet sürüségét?

- A hullámtéri növényzet milyen hatással van a hordalék felhalmozódására?

\section{A hordalék felhalmozódását a part menti sávban befolyásoló tényezők vizsgálata}

A kanyarulatok külső ívén fejlődő folyóhátak és a belső íven épülő övzátonyok a meder közvetlen közelében kialakuló legjellegzetesebb formák, amelyek a hullámtéri feltöltődés kitüntetett helyei, így a feltöltődést befolyásoló bármely tényező megváltozása tükröződhet a formák méretein és alaktani tulajdonságain. Célul tüztem ki ezen formák azonosítását, és az épülésüket befolyásoló tényezők vizsgálatát. A folyóhátak vizsgálata során a következő kérdésekre keresem a választ:

- A folyóhátak magasságát, szélességét és épülésük ütemét mely főbb tényezők határozzák meg?

- A folyóhátak épülésének ideje milyen kapcsolatban áll a formák méretével?

Az övzátonyok vizsgálata során nem csak a legfiatalabb, aktívan épülő formákat, de az egyes övzátony-sorokat alkotó idősebb tagokat is célom megvizsgálni, hiszen ezek a horizontális feltöltődés időbeli változásaira utalhatnak. A dolgozatom ezen szakaszában a követező kérdések merültek fel:

- A kanyarulatok vándorlási típusa mennyiben befolyásolja az övzátonyok morfológiai jellemzőit?

- A partelmozdulás üteme hogyan befolyásolta az egyes övzátonyformák magassági és szélességi viszonyait?

- Az övzátony-sorokat alkotó tagok magasságának meder irányában történő változása és szélességük alapján milyen övzátony-fejlödési típusok különíthetők el? Ezek milyen folyamatokra utalnak?

- Az övzátony-sorokat alkotó tagok magasságát és szélességét milyen elsődleges tényezők befolyásolják?

Dolgozatom eredményei választ adhatnak egyrészt arra, hogy az Alsó-Tisza hullámterén melyek azok a területek, ahol fokozott hordalék-lerakódás figyelhető meg, másrészt ezt az intenzív hordalék-felhalmozódást milyen tényezők okozzák, ezáltal azonosíthatók azok a kitüntetett helyek, amelyek akadályt képeznek az árvizek levonulásának. Ezen eredmények hasznosíthatók az árvízi előrejelzésben, illetve felhasználhatók a Vásárhelyi Terv Továbbfejlesztése céljainak hatékonyabb megvalósításában is. A Terv kiemelt célja ugyanis a hullámtéren az áramlási és vízszállítási feltételek javítása, amelynek egyik feltétele a táj-és földhasználat megváltoztatása. Ezen kívül a Terv célja az árvízi tározók és a nagyvízi meder vízszállító képességének javításával a tetőző vízállások 1 m-rel való csökkentése, amihez az általam végezett kutatások jó alapul szolgálhatnak. 


\section{Irodalmi előzmények}

A fejezetben először áttekintem a hullámterek feltöltődésével kapcsolatos legfontosabb hazai és nemzetközi kutatásokat. Et követően bemutatom, hogy a hordalék felhalmozódását milyen helyi, azaz a hullámtér szintjén ható tényezők befolyásolják, és ezzel kapcsolatban milyen fontosabb eredmények születtek. Fontosnak tartom a hosszú- és rövidtávú feltöltődés mérési módszerinek bemutatását is, kiemelve azok előnyeit és hátrányait. Végül kiemelten foglalkozom a folyóhátak és övzátonyok épülésének és a formálódásukat befolyásoló tényezők bemutatásával. Ezek a formák ugyanis a vertikális és horizontális hordalékfelhalmozódás kiemelt színterei, így a formálódásukat befolyásoló bármely tényező megváltozására érzékenyen reagálnak.

\subsection{A hullámtér általános feltöltődése}

\subsubsection{A hullámterek feltöltődésének mértéke}

Hazánkban a hullámtér feltöltődésének kérdése és problémája a 19. századi folyószabályozások és árvíz-mentesítési munkálatokat követően merült fel. Az árvízvédelmi töltések kiépítése következtében a Tisza által szállított hordalékmennyiség a jóval kisebb területü hullámtéren rakódott le, és indult intenzív felhalmozódásnak (Jakucs 1982). Az ármentesítések tervezése és kivitelezése során a hullámtéri feltöltődést, mint következményt nem vették figyelembe, és annak vízjárásra gyakorolt hatásától eltekintettek. Félegyházi (1929) különböző időpontokban készült felvételek alapján számszerüsítette a meder egyes paramétereiben - kisvízi és középvízi mélység és szélesség - a szabályozások óta bekövetkezett változásokat, de az ártéri hordalék-lerakódásra még nem fordított figyelmet.

Károlyi (1960) az elsők között volt, aki tényleges méréseket végzett a Tisza hullámterén, és eredményire alapozva becsülte meg a teljes magyarországi Tisza szakaszon az ármentesítések óta felhalmozódott üledék vastagságát, amit 0,3-0,5 méterre becsült. Ennél vastagabb lerakódást például a Tisza szolnoki szelvényében (1-1,5 m) és Tiszakécskén $(1 \mathrm{~m})$, a Felső-Tiszavidéken a Tuzsér környéki szakaszon $(1 \mathrm{~m})$ és Tiszabercel környékén (1-1,6 m) határozott meg. A lokális eltérések okaként a szükebb hullámteret, valamint a felsőbb szakaszokon a gyorsabb kanyarulatképződés során fellépő intenzívebb medererózió által termelt nagyobb hordalékmennyiséget adta meg. Borsy (1972) a Felső-Tiszán és mellékfolyóin az 1970-ben végig vonult rekordárvizet követően végzett méréseket a Szamos mentén a Szatmári-síkon. Megállapította, hogy a mederhez közel halmozódik fel a hordalék nagy része $(20-80 \mathrm{~cm})$, amelynek oka a hirtelen vízsebesség-csökkenés, míg a folyótól távolabb, a gátak tövében legfeljebb $3 \mathrm{~mm}$ volt az üledék vastagsága. Mérései alapján becslést tett a szabályozások óta felhalmozódott hordalékvastagságra is, amely eredményei szerint 50 és $250 \mathrm{~cm}$ között van (ami, ha 1900-tól számítjuk 0,7-3,5 cm/év ütemnek felel meg). Megállapítása szerint a gátak magasítása a mérései idején még nem volt sürgős, hiszen a Szamos medre évente $1 \mathrm{~cm}$-rel bevágódik, ami részben kiegyenlíti a hullámtér feltöltődését. Borsy (1972) véleményével szemben Jakucs (1982) azonban már felhívta a figyelmet a hullámtér feltöltődésének fontosságára, hiszen véleménye szerint a folyamat jelentősen hozzájárulhat az 1900-as évek óta tapasztalható egyre gyakoribb és magasabb árvizek kialakulásához. Felhívta továbbá arra is a figyelmet, hogy a szabályozásokat követően a folyók hordalékmennyisége közel változatlan maradt, amely a szük hullámtereken rakódik le. Becslései szerint negyedidőszaki hordalékmennyiséget feltételezve a folyók hullámtéri felszíne évente átlagosan $11 \mathrm{~cm}$-rel magasodna, azonban a szabályozások eredményeként felgyorsult lefolyás miatt 20\%-kal kevesebb hordalék halmozódik fel a hullámtéren, mint az ármentesítések előtt, de megállapításai szerint a hullámtér feltöltődése még így is túl gyors. Ez pedig a hullámtéri keresztmetszet csökkenéséhez, azaz fokozott árvízveszélyhez vezet. 
A hullámterek feltöltődése az 1998 és 2006 között levonult rekordárvizek kapcsán került a hazai kutatások középpontjába. Ezek a kutatások elsősorban a Tiszára koncentráltak, azonban hasonló kutatások születtek a Duna, a Körösök és a Maros kapcsán is.

Koncsos és Kozma (2007) a teljes magyarországi Tisza szakaszon számítógépes modell segítségével számolták ki a megelőző 50 éves időszakra a hullámtér feltöltődésének ütemét. Eredményeik szerint a Tisza teljes hosszán a hordalék felhalmozódásának átlagos sebessége 0,77 cm/év, amely megfelel a Borsy (1972) által mért eredmények alsó határának $(0,7 \mathrm{~cm} / \mathrm{év})$. Továbbá kiemelték, hogy a Közép-Tisza hullámtere $(1,34 \mathrm{~cm} / \mathrm{e} v)$, azon belül is a Kisköre környéki Tisza-szakasz $(1,91 \mathrm{~cm} / \mathrm{év})$ töltődik fel a legintenzívebben.

A Felső-Tiszán hosszútávú feltöltődést végzett Gábris et al. (2002) a folyó Tiszadob és Tiszaszederkény közötti szakaszán. A mentett ártéri területek és a hullámtér magasságkülönbsége alapján 0,1-0,5 cm/év ütemü (12-60 cm vastag) feltöltődést feltételeztek a szabályozások óta, amelynek eredményeként a hullámtéren az átfolyási keresztmetszet 516\%-kal csökkent. Vass et al. (2009a) szintén a mentett ártér és a hullámtér közötti magasságkülönbség alapján határozta meg a feltöltődés mértékét Tarpa és Jánd között a Tisza jobb partján található négy hullámtéri öblözetben. Eredményeik szerint a szabályozások óta 20-110 cm vastagságú hordalék halmozódott fel. Dezső et al. (2009) ugyanezen a szakaszon, Gulács térségében végzett mérései szerint 1965 és 1986 között több mint $70 \mathrm{~cm}$-t töltődött a Tisza hullámtere, ami 2,3 cm/év felhalmozódásnak felel meg. Szabó et al. (2008) ugyancsak Gulács térségében a szabályozások óta tartó feltöltődést ütemét átlagosan $0,8-1 \mathrm{~cm} /$ évben határozták meg. Tehát Dezső et al. (2009) mérése jóval gyorsabb ütemü feltöltődést jelez, mint amelyet Vass et al. (2009a) és Szabó et al. (2008) kimutatott. Ennek oka lehet egyrészt, hogy nem ugyanolyan hosszú időszakot vizsgáltak, előbbi szerzők csupán 20 éves, míg utóbbiak közel 100 éves időszakot vizsgáltak, így ez alapján feltételezhető, hogy a Tisza hullámterének felöltődése egyre gyorsabb ütemü. Másrészt, míg Vass et al. (2009a) csupán széles hullámtéri szakaszokat vizsgált, addig a Dezső et al. (2004) és Szabó et al. (2008) által elemzett hullámtér szük szakaszokat is magába foglal.

Rövidtávú, azaz egy-egy árvízi esemény utáni hordalék-felhalmozódást vizsgált Gönczy és Molnár (2004) Telekháza és Tiszaújlak között az 1998 és 2001 évi árvizeket követően. Méréseik szerint a két árvíz során átlagosan 21,9 cm (19,2-135 cm) vastagságban halmozódott fel a hordalék. Vass (2007) a Beregi-síkon vizsgálta a feltöltődés mértékét és mintázatát a 2001. évi árvizet követően, de nem csak a hullámtéren, de a tarpai gátszakadást követően a mentett ártéri területeken lerakódott hordalék vastagságát és minőségét is elemezte. A Tisza hullámterén 1-15 cm-es, míg a mentett ártéri területen, ahol a gát átszakadt 1-2 mm-es üledékvastagságot mért.

A Közép-Tiszán végzett kutatások többsége Szolnok környékére koncentrált. A Tisza szolnoki szelvényében a hosszútávú feltöltődést elsőként Károlyi (1960) vizsgálta, aki 1-1,5 m-re becsülte a szabályozások óta felhalmozódott hordalékmennyiséget. Nagy et al. (2001) és Schweitzer (2001a) kiemelték, hogy az árvízszintek 21. sz. elején tapasztalt emelkedéséért elsősorban a hullámtéren végbemenő változások - annak feltöltődése és növényzettel való benőttsége - okolhatók, nem pedig a Felső-Tisza vízgyüjtőjében végbemenő területhasználatváltozások és erdőirtások. Az általuk vizsgált folyóháton (a szerzők ezt övzátonynak vagy parti gátnak nevezik) a feltöltődést fúrásminták alapján 2,5 m-re becsülték, és megállapították, hogy egy-egy árvíz alkalmával 10-45 cm hordalék rakódik le a folyóhát felszínén (Nagy et al. 2001, Schweitzer et al. 2002). Ezt a formát Braun et al. (2003) is elemezte, aki radioaktív izotópok segítségével kimutatta, hogy 1916 óta évente átlagosan 2-3 cm-rel emelkedik. Szlávik (2001) szintén Szolnok térségében vizsgálta a hullámtér feltöltődését. Eredményei szerint az 1950-es évektől 120 cm-rel emelkedtek a folyóhátak. Balogh et al. (2005) Szolnok és Vezseny közötti szakaszon mérték a szabályzások óta felhalmozódott hordalék vastagságát, a szabályozások előtt keletkezett paleotalaj marker rétegként felhasználva. Megállapították, hogy a feltöltődés Szolnoknál 0-2 m, míg Vezseny térségében 0,4-0,75 m közötti. Sándor és Kiss (2006a) Szolnok és Nagykörü térségében létesített kutatóárkokban vizsgálták a hosszú 
távú feltöltődést az üledék nehézfémtartalom vizsgálata alapján. Megállapították, hogy a Szolnok térségében $108 \mathrm{~cm}(0,8 \mathrm{~cm} /$ év) a feltöltődés, míg Nagykörü térségében ennél némileg kevesebb, 58-60 cm $\left(0,4 \mathrm{~cm} / \mathrm{é}^{2}\right)$. A feltöltődés gyorsuló ütemére is felhívták a figyelmet, hiszen 2000 és 2005 között az egyik szolnoki szelvényükben $68 \mathrm{~cm}$ vastag hordaléklerakódást mértek, amely 13,6 cm/év ütemnek felel meg. Ezt a gyorsuló ütemet bizonyítják Sándor és Kiss (2006b) további mérései, miszerint Szolnok térségében a feltöltődés üteme 1965-70 előtt 0,3-0,8 cm/év volt, azután pedig 1-1,5 cm/évre növekedett, tehát a feltöltődés sebessége megduplázódott. Tanulmányukban egy folyóhátat is vizsgáltak, amely 1890 óta átlagosan 0,6 cm/év (0,1-4 cm/év) ütemben épült, viszont az 1976 és 2000 közötti időszakban inkább az erózió jellemezte a formát $\left(-0,8 \mathrm{~cm} / \mathrm{e}^{\mathrm{v}}\right)$, amelyet a sodorvonal parthoz való közelebb kerülésével magyaráztak. A feltöltődés általános sebességének hirtelen növekedését Sándor és Kiss $(2007,2008)$ a felszín érdességének növekedésével magyarázták, hiszen az 1960-as évektől az invazív fajok (pl. gyalogakác) gyors terjedésnek indultak, illetve az intenzívebbé vált az erdőmüvelés is, amely a tuskógátak megjelenését eredményezte a hullámtéren.

Rövidtávú feltöltődést Oroszi et al. (2006a) végzett a 2005. évi árvizet követően a Közép-Tisza egy szolnoki kanyarulatában. Eredményeik szerint a legintenzívebb hordalékfelhalmozódás a part menti szükebb sávban volt jellemzö, hiszen az övzátony felszínén $19 \mathrm{~cm}$ volt a friss üledék vastagsága. A kanyarulat egészét tekintve a legtöbb hordalék $(>10 \mathrm{~cm})$ a kanyarulat alvíz felöli csúcsán, a külső íven rakódott le, ahol az intenzív akkumulációval jellemezhető zóna ki is szélesedett. Méréseik szerint a parttól távolodva az üledék vastagsága exponenciálisan csökkent, a medertől 15-20 m-re már $1 \mathrm{~cm}$-nél vékonyabb volt. A szerzők kiemelték, hogy a növényzetnek meghatározó szerepe lehet a feltöltődés mintázatának módosításában, ugyanis sürü aljnövényzetü fiatal erdőkben az intenzív partépülés zónája keskenyebb volt, mint a ritkább aljnövényzettel rendelkező idősebb erdőállományokban. Ugyanezen a helyen végzett méréseket a következő, 2006. évi árvizet követően Sándor és Kiss (2007). Eredményeik szerint a part menti sávban átlagosan 0,8-1 cm hordalék halmozódott fel, míg a legintenzívebben az övzátonyok és a folyóhátak töltődtek, felszínükön több mint $5 \mathrm{~cm}$ volt az üledékvastagság. A medertől legtávolabb eső területeken, az árvízvédelmi töltések tövében viszont csökkent a hordalék mennyisége $(<0,5 \mathrm{~cm})$ és szemcsemérete is.

Az Alsó-Tisza menti hosszútávú feltöltődéssel kapcsolatban is közölt adatokat Szlávik (2001). Eredményei szerint a hullámtér Kisköre és Szeged között átlagosan $5 \mathrm{~cm} /$ év ütemmel iszapolódott fel az 1976 és 1983 közötti időszakban. Megállapította, hogy a teljes hordalékmennyiség 1/4-1/5 része a part menti 30-50 m-es sávban halmozódik fel. és kiemelte, hogy a folyóhátak a legintenzívebben feltöltődő formák, amelyek felszínén 60-80 cm vastag hordalék is felhalmozódhat. Sándor és Kiss (2006b) az Alsó-Tisza mentén is kimutatták a hullámtér feliszapolódásának hosszútávon bekövetkező gyorsulását. A Mártélyi-holtág egykori övzátonyának felszínéről és egy belső hullámtéri területről vett üledékminták alapján a magas ólomtartalmú rétegek alapján határozták meg a hordalék felhalmozódásának sebességét. Eredményeik szerint az egykori, a szabályozások óta nem aktív övzátony felszínén 1960-75 elött a feltöltődés sebessége 0,4-0,7 cm/év volt, azt követően pedig 1,2-1,5 $\mathrm{cm} /$ évre gyorsult. Ugyanezt tapasztalták a belső hullámtéri területen is, ahol a feltöltődés sebessége 0,2-0,3 cm/évröl 0,4 cm/évre növekedett.

Keller és Marsovszki (1992) egy rövid (6-7 éves) periódust vizsgálva megállapították, hogy a part menti folyóhátak töltődnek a legintenzívebben, amelynek átlagos mértéke $30 \mathrm{~cm}$. az Alsó Tiszával kapcsolatban is közölt adatokat a hosszútávú feltöltődésre vonatkozóan. Kiss és Fejes (2000) Mindszent térségében végzett méréseket az 1998-as őszi és 1999-es tavaszi árvizet követően. Ezek az árvizek átlagosan $1 \mathrm{~cm}$ üledék-lerakódást eredményeztek a mintaterületen, de eredményeik szerint is a kanyarulat külső ívén, a part menti szük $(10-75 \mathrm{~m})$ sávban volt a legnagyobb az felhalmozódás mértéke, amely mindenhol meghaladta az $50 \mathrm{~cm}$ t. A kanyarulat belső oldalán, az övzátony-sorok esetében jól kivehetők voltak az egyes 
áradások nyomai, mivel az először lerakódó homokszemcséket később iszapos-agyagos réteg fedte be, majd a tavaszi árvizet követően ez megismétlődött. Ugyanitt végzett méréseket Kiss et al. (2002) az előbbi eredményeket kiegészítve a 2000-ben levonult árhullám idején lerakódott üledék vastagságával. A feltöltődés mértékének meghatározása mellett értékelték az üledék-felhalmozódás mintázatát is, illetve azt, hogy egy-egy árvizes időszak eltelte után a partokról mennyi anyag kerül vissza a mederbe. Eredményeik azt mutatják, hogy a legtöbb üledék a folyóhátakon és övzátonyokon rakódott le $(10-70 \mathrm{~cm})$, míg a legkevesebb az árvízvédelmi töltések tövében $(0,1-1,5 \mathrm{~cm})$. Megállapították, hogy az árvizek levonulása után tömegmozgásos folyamatok indulnak meg a part mentén, és kisvizes időszakokban a meder felé történő hordalékmozgás akár $40-50 \mathrm{~cm} /$ nap is lehet. Szintén Mindszent térségében végzett hordalékvastagság-méréseket Végh (2016) a 2013. évi árvizet követően. Vizsgálatai során kimutatta a hullámtéri feltöltődés mintázatának megváltozását. Eredményei szerint a legintenzívebb $(>10 \mathrm{~cm})$ hordalék-felhalmozódással jellemezhető sáv szélessége lecsökkent, egyre inkább a parthoz simult, amelyet a part menti növényzet sürübbé válásával magyarázott.

A Maros hullámterének feltöltődését szintén vizsgálták hosszú- és rövidtávon is. Oroszi és Kiss (2004) három Makó környéki hullámtéri öblözetben vizsgálták a holtágak feltöltődését. Eredményeik szerint a Vetyeháti öblözetben $255 \mathrm{~cm}$ vastag hordalék halmozódott fel (1,8 cm/év), a zugolyi holtágban $170 \mathrm{~cm}(1,3 \mathrm{~cm} / \mathrm{év})$, míg Csordajárás területén $245 \mathrm{~cm}$ volt az üledék vastagsága, ami $2,45 \mathrm{~cm} / \mathrm{é}^{2}$ ütemnek felel meg a szabályozások óta. Pollenanalitikai vizsgálatok segítségével kimutatták a feltöltődés gyorsuló ütemét, miszerint a parlagfü 1960-as évekbeli megjelenése óta a hordalék felhalmozódása 3,2 cm/évre gyorsult. Később Kiss et al. (2011) a Maros teljes magyarországi szakaszán vizsgálták a feltöltődés ütemét DDM segítségével határozva meg a hullámtéri és a mentett ártéri területek magasságkülönbségét. Eredményeik szerint a szabályozások óta átlagosan 1,2 $\mathrm{cm} / \mathrm{é}_{\mathrm{v}}$ a hordalék felhalmozódásának üteme a Maros teljes hullámterén. A folyó hazai szakaszát öt egységre osztották a lejtésviszonyok, a mederrendezés előtti természetes geomorfológiai formakincs és az aktív hordalék-felhalmozódási folyamatok alapján. A legkisebb mértékü feltöltődést az alacsonyabb fekvésü ártéri egységben mérték, itt a felhalmozódás átlagos üteme $0,4 \pm 0,2 \mathrm{~cm} /$ évnek adódott, míg a leggyorsabb feltöltődést a Tisza torkolatához legközelebb eső egységben mutatták ki $(2 \pm 0,5 \mathrm{~cm} / \mathrm{e} v)$. A feltöltődés eredményeképpen az árvizek levezetésére szolgáló hullámtéri keresztmetszet 19-35\%-kal csökkent.

Rövidtávú feltöltődést Oroszi et al. (2006ab) és Oroszi (2008) vizsgálta a 2005. és 2006. évi árvizeket követően. A Vetyeháti Holt-Maros öblözetében a 2005. évi árvíz után a hordalék a legnagyobb vastagságban $(15-18 \mathrm{~cm})$ egy ívesebb kanyarulat belső ívén rakódott le, illetve ettől a ponttól folyásirányban lefelé, ahol a sodorvonal a folyóparthoz szorul, és így intenzívebb folyóhát-épülés zajlik (Oroszi et al. 2006ab). A vizsgálatokat a 2006-os árvizet követően kiterjesztették Apátfalva térségére is, ahol a parttól 80-190 m-es sávban figyeltek meg intenzív akkumulációt, ahol átlagosan $22 \mathrm{~mm} \mathrm{~cm}$ vastag hordalék rakódott le (Oroszi 2008). A legnagyobb vastagságban $(11 \mathrm{~cm})$ közvetlenül a part mentén halmozódott fel, de ennél vastagabb üledékréteget $(9-11,5 \mathrm{~cm})$ is megfigyeltek a parthoz közeli kubikgödrökben. A 2006-os árvíz a vetyeháti öblözetben jóval szélesebb (250-350 m) sávban, és átlagosan 23,8 $\mathrm{cm}$-es vastagságban halmozott fel hordalékot. A legnagyobb üledékvastagságot $(22-26 \mathrm{~cm})$ a kanyarulatok belső ívén, annak alsó harmadában mérte Oroszi (2008). Az aktív medertől távolabb vastagabb hordalék-felhalmozódást a holtágakban mért $(30-34 \mathrm{~mm})$, illetve megfigyelte, hogy a holtágak partjaitól távolodva is jellemző volt az üledék vastagságának exponenciális csökkenése, így a levágott kanyarulatoknak kiemelt hordalékszállító ésakkumuláló szerepe lehet.

Az eddigi kutatások alapján a Tisza és a Maros hullámterének feltöltődését összehasonlítva elmondható, hogy a Maros hullámtere jóval gyorsabb ütemben töltődik. Kiss et al. (2011) ezt a két folyó eltérő hidromorfológiai tulajdonságaival magyarázta, hiszen a 
Maros jóval több lebegtetett hordalékot szállít, nagyobb az esése, lassabb a kanyarulatvándorlás üteme, és a hullámtér is szükebb.

A Bodrog mentén Vass et al. (2009b) a Bodrogzugban található övzátonyok és sarlólaposok feltöltődési ütemét vizsgálta üledékcsapdák segítségével. A területen végigvonult magas árhullám ellenére jelentősebb eredményeket nem kaptak, ugyanis a part menti sávban a sürű növényzet felfogta a hordalék nagy részét, így az a hullámtér távolabbi területeire nem tudott eljutni.

A Körösök menti feltöltődés mértékéröl Schweitzer (2001ab) és Babák (2006) közölt adatokat. Schweitzer (2001) vizsgálatai szerint Békésszentandrás térségében a szabályozások óta 160-180 cm vastag hordalék rakódott le, illetve szelvényminták alapján árvizenként 5-13 cm vastag felhalmozódás történt. Babák (2006) a Hármas-Körös Kunszentmárton és Öcsöd közötti szakaszán végzett vizsgálatok alapján megállapította, hogy a szabályozások óta 150$180 \mathrm{~cm}$ üledék halmozódott fel, azaz a Hármas-Körös hullámtere évente 1,2 cm-rel emelkedik.

A Duna hullámterének szabályozások óta tartó feliszapolódásával csupán néhány kutatás foglalkozott. Tamás és Kalocsa (2003) a Rezéti-Holt-Duna feltöltődésének sebességét vizsgálták, ami egy, a mai hullámtéren belül lévő holtág, amelynek medre nem volt kotorva, így a feltöltődés természetes folyamata jól vizsgálható. Méréseik szerint a holtág mederszélessége a szabályozások óta $80-90 \%$-kal csökkent. A szerzők megállapították, hogy a Duna főmedréből érkező lebegtetett hordalékmennyiség 90\%-a a mellékágban rakódik le, és becsléseik szerint ilyen intenzív hordalék-felhalmozódás mellett a holtág egésze 2030-2050-re teljesen fel fog töltődni.

A világ más tájain is hasonlóan kiemelt probléma a hullámterek intenzív feltöltődése, kifejezetten azokon a területeken, ahol a folyók jelentős antropogén beavatkozásokon estek át (1. táblázat). A hordalék felhalmozódásának mennyisége és sebessége azonban folyónként, és éghajlati területenként meglehetősen változó. Míg Európában igen gyakoriak az egy-egy árvízi esemény után végzett mérések, addig az amerikai kontinensen és Ausztráliában végzett hosszútávú feltöltődést célzó kutatások nagy része az 1700-as és 1800-as évek során megjelent európai telepesek tevékenysége következtében meginduló intenzívebb hullámtéri feltöltődéssel foglalkozott. Az új települések megjelenésével megindult a földmüvelés és legeltetés, amely maga után vonta jelentős erdőterületek kiirtását, így az intenzívebb talajerózió a hullámterek feltöltődésének gyorsulását eredményezte (Eyles 1977, Beach 1994, Wasson et al. 1998, Knox 2006).

1. táblázat. Hosszú-és rövidtávú hullámtéri feltöltödéssel kapcsolatos föbb nemzetközi kutatások

\begin{tabular}{|c|c|c|c|c|c|c|}
\hline & Szerző & Folyó & $\begin{array}{l}\text { Feltöltödés } \\
\text { ideje }\end{array}$ & $\begin{array}{l}\text { Alkalmazott } \\
\text { módszer }\end{array}$ & $\begin{array}{c}\text { Feltöltődés vastagsága/ } \\
\text { üteme }\end{array}$ & $\begin{array}{c}\text { Feltöltődést } \\
\text { befolyásoló } \\
\text { tényező }\end{array}$ \\
\hline & $\begin{array}{l}\text { Gretener és } \\
\text { Strömquist } \\
(1987)\end{array}$ & $\begin{array}{l}\text { Fyrisån, } \\
\text { Svédország }\end{array}$ & $\begin{array}{l}\text { 1986. évi } \\
\text { árvíz }\end{array}$ & $\begin{array}{l}\text { hordalék- } \\
\text { csapdák }\end{array}$ & $\begin{array}{l}\text { hullámtéren: } 5,3 \mathrm{t} \\
\text { hordalék }(0,03 \mathrm{~mm} / \mathrm{e} \mathrm{v}) \\
\text { folyóháton: } 119,5 \mathrm{~g} / \mathrm{m}^{2} \\
\text { folyóhát mögött: } 56 \mathrm{~g} / \mathrm{m}^{2} \\
\text { elhagyott mederben: } 98 \\
\mathrm{~g} / \mathrm{m}^{2}\end{array}$ & $\begin{array}{l}\text { hullámtér- } \\
\text { morfológia }\end{array}$ \\
\hline$E$ & $\begin{array}{l}\text { Lambert és } \\
\text { Walling } \\
(1987)\end{array}$ & $\begin{array}{l}\text { Culm folyó, } \\
\text { Devon, UK }\end{array}$ & $\begin{array}{l}\text { 1982. és } \\
\text { 1984. évi } \\
\text { árvizek }\end{array}$ & $\begin{array}{l}\text { hordalék- } \\
\text { csapdák }\end{array}$ & $\begin{array}{l}\text { hullámtéren: átl. 0,49 } \\
\text { mm/év }\end{array}$ & $\begin{array}{l}\text { hullámtér- } \\
\text { morfológia, } \\
\text { elöntés hossza, } \\
\text { vízáramlás } \\
\text { sebessége }\end{array}$ \\
\hline
\end{tabular}




\begin{tabular}{|c|c|c|c|c|c|}
\hline $\begin{array}{l}\text { Walling és } \\
\text { He (1994) }\end{array}$ & $\begin{array}{l}\text { Exe, Culm, } \\
\text { Stour, Avon } \\
\text { és Severn } \\
\text { folyók, UK }\end{array}$ & $\begin{array}{l}\text { utóbbi } \\
100 \text { év }\end{array}$ & $\begin{array}{l}{ }^{137} \mathrm{Cs}-\quad \text { és } \\
{ }^{210} \mathrm{~Pb}- \\
\text { koncentráció }\end{array}$ & $\begin{array}{l}\text { Exe: } 0,42-0,45 \mathrm{~g} / \mathrm{cm}^{2} / \mathrm{év}^{2} \\
\text { Culm: } 0,22-0,35 \mathrm{~g} / \mathrm{cm}^{2} / \mathrm{e} v \\
\text { Stour: } 0,04 \mathrm{~g} / \mathrm{cm}^{2} / \mathrm{év}^{2} \\
\text { Avon: } 0,17-0,19 \mathrm{~g} / \mathrm{cm}^{2} / \mathrm{e} v \\
\text { Severn: } 0,86-0,95 \\
\mathrm{~g} / \mathrm{cm}^{2} / \mathrm{év}\end{array}$ & $\begin{array}{l}\text { hullámtér- } \\
\text { morfológia, } \\
\text { medertől való } \\
\text { távolság }\end{array}$ \\
\hline $\begin{array}{l}\text { Asselman } \\
\text { és } \\
\text { Middlekoop } \\
\text { (1995) }\end{array}$ & $\begin{array}{l}\text { Maas és } \\
\text { Waal folyó, } \\
\text { Hollandia }\end{array}$ & $\begin{array}{l}\text { 1993. évi } \\
\text { árvíz }\end{array}$ & $\begin{array}{l}\text { hordalék- } \\
\text { csapdák }\end{array}$ & $\begin{array}{l}\text { hullámtéren: átl.0,57-1 } \\
\mathrm{kg} / \mathrm{m}^{2}(0,47-0,82 \mathrm{~mm}) \\
\text { folyóháton: }>4 \mathrm{~kg} / \mathrm{m}^{2} \\
(>33 \mathrm{~mm}) \\
\text { alacsonyabban fekvö } \\
\text { hullámtéri területen: } 1,6 \\
\mathrm{~km} / \mathrm{m}^{2}(13 \mathrm{~mm})\end{array}$ & $\begin{array}{l}\text { hullámtér- } \\
\text { morfológia, } \\
\text { medertől való } \\
\text { távolság, } \\
\text { elöntés hossza }\end{array}$ \\
\hline $\begin{array}{l}\text { Walling et } \\
\text { al. (1997) }\end{array}$ & $\begin{array}{l}\text { Ouse, } \\
\text { Yorkshire, } \\
\text { UK }\end{array}$ & $\begin{array}{l}\text { 1995. évi } \\
\text { árvíz }\end{array}$ & $\begin{array}{l}\text { hordalék- } \\
\text { csapdák }\end{array}$ & $\begin{array}{l}\text { mederhez közel a parton: } \\
>2 \mathrm{~cm} \\
\text { medertől legtávolabbi } \\
\text { területeken: néhány mm }\end{array}$ & $\begin{array}{l}\text { medertől való } \\
\text { távolság, } \\
\text { hullámtér- } \\
\text { morfológia }\end{array}$ \\
\hline $\begin{array}{l}\text { Wyżga } \\
\text { (1999) }\end{array}$ & $\begin{array}{l}\text { Skawa, } \\
\text { Lengyelor- } \\
\text { szág }\end{array}$ & $\begin{array}{l}\text { 1997. évi } \\
\text { árvíz }\end{array}$ & $\begin{array}{l}\text { terepi mérés és } \\
\text { mintagyüjtés } \\
\text { árvizet } \\
\text { követően }\end{array}$ & $\begin{array}{l}\text { folyóháton: max. } 30 \mathrm{~cm} \\
\text { folyóhát mögött: } 15-20 \\
\mathrm{~cm} \\
\text { hullámtér távolabbi } \\
\text { területein: } 0,5-5 \mathrm{~cm}\end{array}$ & $\begin{array}{l}\text { vízáramlás } \\
\text { sebessége, } \\
\text { hullámtér- } \\
\text { morfológia, } \\
\text { part menti } \\
\text { növényzet }\end{array}$ \\
\hline $\begin{array}{l}\text { Álvarez- } \\
\text { Iglesias et } \\
\text { al. (2007) }\end{array}$ & $\begin{array}{l}\text { Ría de Vigo, } \\
\text { Spanyolor- } \\
\text { szág }\end{array}$ & 1963 óta & $\begin{array}{l}{ }^{137} \mathrm{Cs}-\text { és }{ }^{210} \mathrm{~Pb}- \\
\text { koncentráció }\end{array}$ & $\begin{array}{l}\text { alsó homokos rétegek: } \\
3,1 \pm 0,5 \mathrm{~mm} / \mathrm{e} v \\
\text { felső iszapos rétegek: } \\
6,2 \pm 1,2 \mathrm{~mm} / \mathrm{e} v\end{array}$ & $\begin{array}{l}\text { antropogén } \\
\text { hatások: } \\
\text { erdőirtás, } \\
\text { területhasználat- } \\
\text { változás }\end{array}$ \\
\hline $\begin{array}{l}\text { Geerling et } \\
\text { al. (2008) }\end{array}$ & $\begin{array}{l}\text { Waal, } \\
\text { Hollandia }\end{array}$ & 1988 óta & $\begin{array}{l}\text { légifelvételek, } \\
\text { 2D hidraulikai } \\
\text { modell }\end{array}$ & $\begin{array}{l}\text { hullámtéren: átl. } 3,7 \\
\mathrm{~cm} / \text { év } \\
\text { folyóháton: } 15 \mathrm{~cm} / \mathrm{e} v \\
\text { övzátonyon: } 1,23 \mathrm{~cm} / \mathrm{é} \\
\text { hullámtér távolabbi } \\
\text { területein: } 0,013 \mathrm{~cm} / \mathrm{év}\end{array}$ & $\begin{array}{l}\text { antropogén } \\
\text { beavatkozás: } \\
\text { hullámtér } \\
\text { kotrása; } \\
\text { növényzet } \\
\text { megjelenése és } \\
\text { sürúbbé válása } \\
\end{array}$ \\
\hline $\begin{array}{l}\text { Provansal } \\
\text { et al. } \\
(2010)\end{array}$ & $\begin{array}{l}\text { Rhône, } \\
\text { Franciaor- } \\
\text { szág }\end{array}$ & 1950 óta & $\begin{array}{l}{ }^{137} \text { Cs- } \\
{ }^{214} \mathrm{Am}- \\
\text { koncentráció } \\
\text { dendrokronoló- } \\
\text { gia, } \\
\text { szemcseössze- } \\
\text { tétel vizsgálat, } \\
\text { archív } \\
\text { felmérések és } \\
\text { térképek }\end{array}$ & $\begin{array}{l}\text { átlagosan: } 14 \mathrm{~cm} / \mathrm{év} \\
\text { 1950-1972: } 4 \mathrm{~cm} / \mathrm{év} \\
\text { 1972-1993: } 6,5 \mathrm{~cm} / \mathrm{év} \\
\text { 1993-2003: } 23 \mathrm{~cm} / \mathrm{e} v\end{array}$ & $\begin{array}{l}\text { folyó alaktani } \\
\text { tulajdonságai, } \\
\text { szállított } \\
\text { hordalék } \\
\text { mennyisége és } \\
\text { szemcseösszetét } \\
\text { ele, lokális } \\
\text { antropogén } \\
\text { hatások }\end{array}$ \\
\hline $\begin{array}{l}\text { Wallinga } \\
\text { et al. } \\
(2010)\end{array}$ & $\begin{array}{l}\text { Waal, } \\
\text { Hollandia }\end{array}$ & $\begin{array}{l}18 . \\
\text { század } \\
\text { óta }\end{array}$ & OSL & $\begin{array}{l}\text { part menti sávban: } 5-11 \\
\text { mm/év } \\
\text { hullámtér távolabbi } \\
\text { területein: } 2-5 \mathrm{~mm} / \text { év }\end{array}$ & \\
\hline $\begin{array}{l}\text { Hooke } \\
(2016)\end{array}$ & $\begin{array}{l}\text { Guadalentín } \\
\text {-medence, } \\
\text { Spanyolor- } \\
\text { szág }\end{array}$ & $\begin{array}{l}\text { 2012. évi } \\
\text { árvíz }\end{array}$ & $\begin{array}{l}\text { geomorfológiai } \\
\text { térképezés, } \\
\text { RTK GPS, } \\
\text { HEC-RAS } \\
\text { modell }\end{array}$ & hullámtéren: $1-57 \mathrm{~cm}$ & \\
\hline $\begin{array}{l}\text { Sedláček et } \\
\text { al. (2016) }\end{array}$ & $\begin{array}{l}\text { Morva, } \\
\text { Csehország }\end{array}$ & $\begin{array}{l}\text { 1900-as } \\
\text { évek eleje } \\
\text { óta }\end{array}$ & $\begin{array}{l}{ }^{137} \text { Cs- } \\
\text { koncentráció, } \\
\text { mágneses } \\
\text { szuszceptibilit } \\
\text { ás }\end{array}$ & $\begin{array}{l}\text { hullámtéren: } 0,45-0,88 \\
\text { cm/év } \\
\text { holtágakban: } 2,27-4,4 \\
\mathrm{~cm} / \text { év } \\
\text { mederhez közeli } \\
\text { holtágakban: } 6-8 \mathrm{~cm} / \mathrm{e} v\end{array}$ & $\begin{array}{l}\text { folyószabályozá } \\
\text { sok }\end{array}$ \\
\hline
\end{tabular}




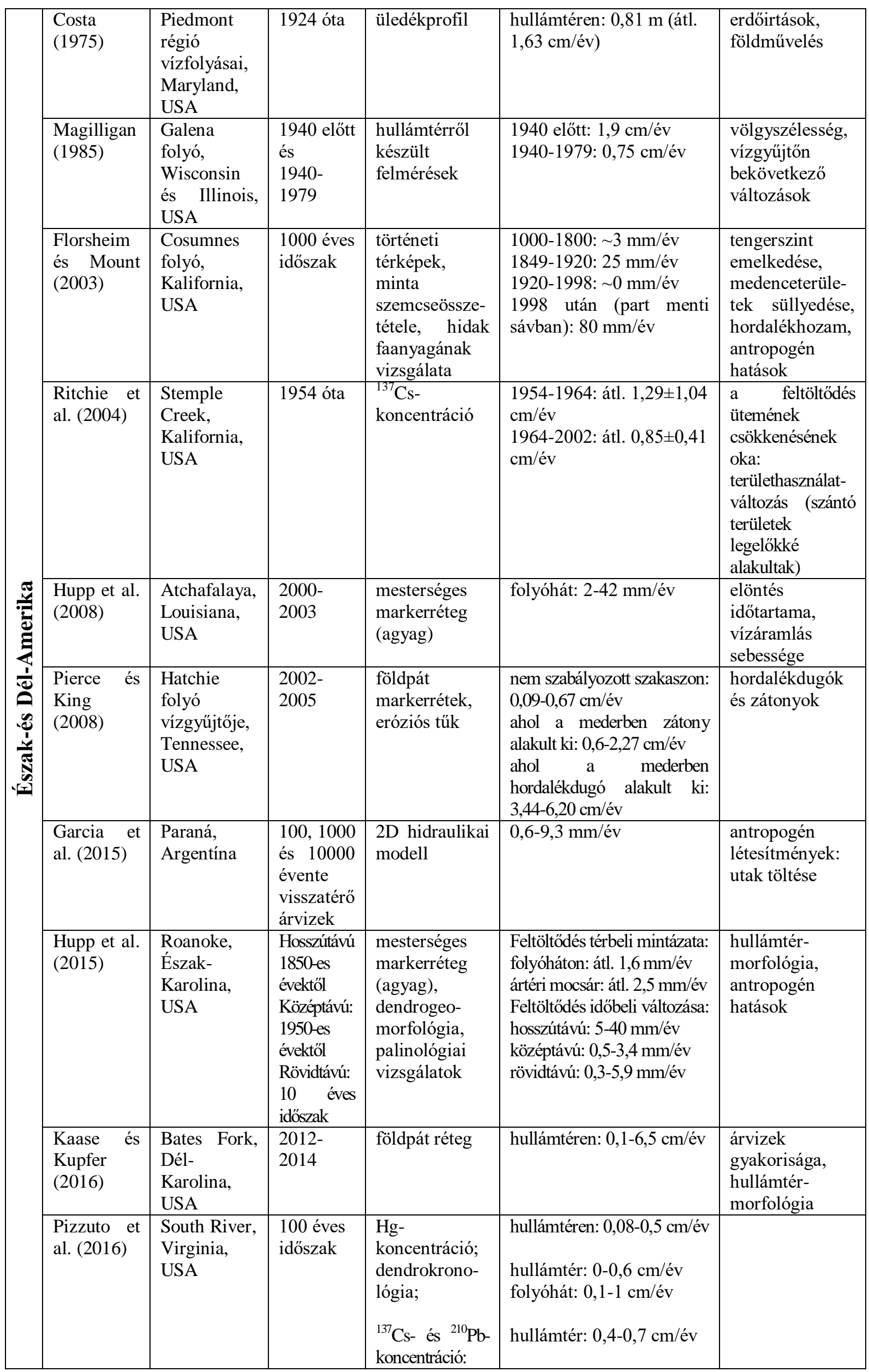




\begin{tabular}{|c|c|c|c|c|c|c|}
\hline \multirow{3}{*}{ 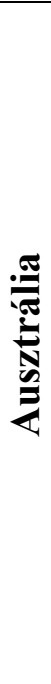 } & $\begin{array}{l}\text { Rustomji } \\
\text { és Pietsch } \\
(2007)\end{array}$ & $\begin{array}{l}\text { Lake } \\
\text { Burragorang } \\
\text { vízgyűjtője }\end{array}$ & 1820 óta & $\begin{array}{l}\text { üledékprofil, } \\
\text { OSL, } \\
\text { hidraulikai } \\
\text { modell }\end{array}$ & $0,1 \pm 0,2-16,4 \pm 30 \mathrm{~mm} / \mathrm{e} v$ & $\begin{array}{l}\text { területhasználat- } \\
\text { változás }\end{array}$ \\
\hline & $\begin{array}{l}\text { Gell et al. } \\
(2009)\end{array}$ & $\begin{array}{l}\text { Murray- } \\
\text { Darling- } \\
\text { medence }\end{array}$ & $\begin{array}{l}\text { 1800-as } \\
\text { évek vége } \\
\text { óta }\end{array}$ & $\begin{array}{l}\text { pollenanalízis, } \\
\text { OSL, }{ }^{137} \mathrm{Cs} \text { - és } \\
{ }^{210} \mathrm{~Pb}- \\
\text { koncentráció, } \\
{ }^{14} \mathrm{C}\end{array}$ & 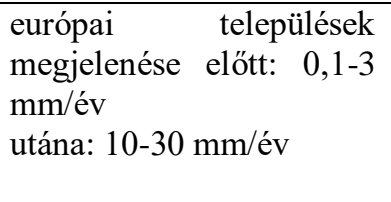 & $\begin{array}{l}\text { területhasználat- } \\
\text { változás, } \\
\text { folyószabályo- } \\
\text { zások }\end{array}$ \\
\hline & $\begin{array}{l}\text { Hughes et } \\
\text { al. }(2010)\end{array}$ & $\begin{array}{l}\text { Theresa } \\
\text { Creek, } \\
\text { Queensland }\end{array}$ & 1850-től & $\begin{array}{l}\text { OSL, } \\
{ }^{137} \mathrm{Cs}- \\
\text { koncentráció }\end{array}$ & $\begin{array}{l}\text { hullámtér: } \\
\text { 1850-es évek előtt: } \leq 0,9 \\
\text { mm/év } \\
1850 \text { körül: } 1,8 \pm 0,5-4 \pm 1,2 \\
\text { mm/év } \\
1850 \text { után: } 0,7 \pm 0,2-1,4 \pm 0,1 \\
\text { mm/év } \\
1954 \text { után: } 2,1 \pm 0,1 \mathrm{~mm} / \text { év }\end{array}$ & $\begin{array}{l}\text { földmüvelés, } \\
\text { legeltetés } \\
\text { megjelenése }\end{array}$ \\
\hline \multirow{4}{*}{$\cdot \frac{\pi}{\frac{\pi}{5}}$} & $\mathrm{Xu}(2003)$ & $\begin{array}{l}\text { Sárga folyó, } \\
\text { Kína }\end{array}$ & $\begin{array}{l}\text { utóbbi } \\
2300 \text { év }\end{array}$ & $\begin{array}{l}\text { történeti } \\
\text { térképek, }{ }^{14} \mathrm{C}, \\
\text { ártérröl } \\
\text { készült } \\
\text { keresztmetszet } \\
\text { ek }\end{array}$ & $\begin{array}{l}\text { i.e. } 300-i . s z .500: 0,2-0,4 \\
\mathrm{~cm} / \mathrm{e} v \\
\text { 1000-1850: } 2 \mathrm{~cm} / \mathrm{e} v \\
\text { 1850-1980: } 2-8 \mathrm{~cm} / \mathrm{é}^{-}\end{array}$ & $\begin{array}{l}\text { klímaváltozás és } \\
\text { antropogén } \\
\text { hatások okozta } \\
\text { felszínborítás- és } \\
\text { területhasználat- } \\
\text { változás }\end{array}$ \\
\hline & $\begin{array}{l}\text { Mizugaki } \\
\text { et al. } \\
(2006)\end{array}$ & $\begin{array}{l}\text { Kushiro } \\
\text { Mire, Japán }\end{array}$ & $\begin{array}{l}20,40 \text { és } \\
100 \text { éves } \\
\text { időszak }\end{array}$ & $\begin{array}{l}\text { dendrokrono- } \\
\text { lógia, }{ }^{137} \mathrm{Cs} \text { - és } \\
{ }^{210} \mathrm{~Pb}- \\
\text { koncentráció }\end{array}$ & $\begin{array}{l}1963 \text { óta: átl. } 1,3 \mathrm{~cm} / \mathrm{é} \\
\text { 1939-1975: } 0,14 \mathrm{~cm} / \mathrm{év} \\
\text { 1975-1981: 8,9 cm/év } \\
\text { 1981-2000: } 2 \mathrm{~cm} / \mathrm{e} v\end{array}$ & $\begin{array}{l}\text { folyószabályo- } \\
\text { zások, } \\
\text { területhasználat- } \\
\text { változás }\end{array}$ \\
\hline & $\begin{array}{l}\text { Tang et al. } \\
(2014)\end{array}$ & $\begin{array}{l}\text { Yangtze, } \\
\text { Kína }\end{array}$ & 2008 óta & $\begin{array}{l}\text { szemcseössze- } \\
\text { tétel, } \\
\text { nehézfém- } \\
\text { tartalom }\end{array}$ & $0,5-10 \mathrm{~cm} / \mathrm{év}$ & $\begin{array}{l}\text { topográfiai } \\
\text { viszonyok }\end{array}$ \\
\hline & $\begin{array}{l}\text { Ishii és } \\
\text { Hori } \\
(2016)\end{array}$ & $\begin{array}{l}\text { Ishikari } \\
\text { folyó, } \\
\text { Hokkaido, } \\
\text { Japán }\end{array}$ & n.a. & ${ }^{14} \mathrm{C},{ }^{137} \mathrm{Cs}$ & $\begin{array}{l}\text { holtágak feltöltődése } \\
\text { közvetlenül a holtág } \\
\text { kialakulása után: } \\
45-90 \mathrm{~mm} / \mathrm{é}^{-} \\
\text {miután megszünt a } \\
\text { fömederrel a kapcsolat: } \\
\text { 3,9-22 mm/év }\end{array}$ & \\
\hline 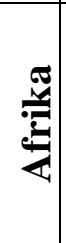 & $\begin{array}{l}\text { Omengo et } \\
\text { al. (2016) }\end{array}$ & $\begin{array}{l}\text { Tana folyó, } \\
\text { Kenya }\end{array}$ & $\begin{array}{l}\text { utóbbi } \\
100 \text { év, } \\
2012 \text { és } \\
2013 \text {. évi } \\
\text { árvíz }\end{array}$ & $\begin{array}{l}\text { mintavétel, } \\
{ }^{137} \mathrm{Cs} \text { - és }{ }^{210} \mathrm{~Pb} \text { - } \\
\text { koncentráció }\end{array}$ & $\begin{array}{l}\text { utóbbi } 100 \text { év: } 1,01 \pm 0,5- \\
1,2 \pm 0,4 \mathrm{~g} / \mathrm{cm}^{2} / \text { év } \\
\text { árvíz után: 2-15 mm } \\
\left(0,88 \pm 0,4 \mathrm{~g} / \mathrm{cm}^{2} / \mathrm{év}\right)\end{array}$ & $\begin{array}{l}\text { medertől való } \\
\text { távolság, } \\
\text { topográfiai } \\
\text { viszonyok, } \\
\text { elöntés } \\
\text { magassága }\end{array}$ \\
\hline
\end{tabular}

A fejezetben bemutatott kutatások jól mutatják, hogy a folyók hullámterén jellemző hosszú távú feltöltődés mértékére nem minden esetben következtethetünk az egy-egy árvízi esemény során lerakódott üledék vastagságából. Ennek oka egyrészt, hogy (1) a lerakódott üledék idővel tömörödik (Vass 2007, Hupp et al. 2008), (2) nem minden évben fordul elö árvíz és ezek során más-más mennyiségü hordalék rakódik le, és nem is biztos, hogy ugyanakkora területen, (3) az árvíz levonulása után az anyag egy része tömegmozgásos folyamatok révén visszajuthat a mederbe (Kiss et al. 2002). Ezen kívül (4) az akkumulációt számos tényező befolyásolja. A bemutatott kutatások mind kimutatták, hogy az ártereken/hullámtereken a feltöltődés mintázatát alapvetően befolyásolja a medertől való távolság, a legvastagabb hordalék a mederhez közel, elsősorban a folyóhátak és az övzátonyok felszínén rakódik le, míg a folyótól távolodva a hordalék vastagsága és szemcsemérete fokozatosan csökken. Ezen kívül jelentős hatása van az antropogén beavatkozásoknak (folyószabályozások, gátépítések, területhasználat megváltozása), amelyek alapvetően módosítják a hullámtéren zajló folyamatokat, és drasztikus változást idéznek elö a feltöltődés sebességében. 


\subsubsection{Az árterek feltöltődését befolyásoló tényezők}

A hullámterek feltöltődése komplex folyamat, amely számos, a vízgyüjtö szintjén és lokálisan, a hullámtér adott szakaszán ható tényező együttes eredményeként megy végbe. A vízgyüjtő szintjén ható tényezők, például a vízgyüjtő terület domborzata, alakja, lejtése, felszínborítása, és a lefolyási viszonyok a folyómederbe jutó hordalék mennyiségét és minőségét szabályozzák (Chorley et al. 1985, Nanson és Croke 1992). Az ártér egy adott szakaszán érvényesülő tényezők hatása lokálisabb, hiszen az ártérre/hullámtérre kilépő víz- és hordalék mennyiségét, illetve a felszínen lerakódó hordalék térbeli mintázatát szabályozzák (Walling és He 1998). Azonban a feltöltődést befolyásoló természetes tényezők szerepét felülírhatják az antropogén hatások, amelyek hazánkban elsősorban a 19-21. század során szabályozott síkvidéki vízfolyások mentén érvényesülnek (Kvassay 1902, Károlyi 1960, Biedenharn et al. 2000, Kesel 2003). Dolgozatomban a helyi szinten ható tényezöket vizsgálom, így a következőkben ezek szerepét mutatom be részletesen.

\section{A) Árvizek hidrológiai sajátosságainak hatása az árterek feltöltödésére}

Az ártéren akkumulálódó hordalék vastagsága függ az áradó folyó által szállított lebegetett hordalékmennyiségtől, amely évszakonként eltérő lehet, hiszen például a tél végi hóolvadások idején a növényzettel még nem borított felszínröl nagyobb mennyiségü hordalék tud a mederbe erodálódni (Knighton 1998). Továbbá az árvizek áradó és apadó ágában is eltérő mennyiségű hordalék szállítódhat (Bogárdi 1955). Sándor (2011) vizsgálatai szerint a Tiszán a legtöbb lebegtetett hordalék a tavaszi és kora nyári árvizekkor, és az árhullámok áradó ágaiban szállítódik.

$\mathrm{Az}$ ártér topográfiai viszonyai és a növényzet sürüsége jelentősen módosíthatja az áramlási viszonyokat, a vízáramlás sebességét és az elöntés időtartamát is, amelyek meghatározzák, hogy mennyi hordalék halmozódik fel az ártéren. A mélyedésekben (pl. sarlólaposok, kubikgödrök, holtágak) a víz megrekedhet, így ezeken a területeken a hordalék felhalmozódására több idő áll rendelkezésre (Asselman és Midllekoop 1995). A felszín mélyedése és a fokok ezzel szemben felgyorsíthatják a vízáramlást (van den Berg és van Gelder 1993). A ritkább erdők, irtások és nyiladékok a vízáramlás felgyorsulását eredményezik, míg igen sürü erdőkben és invazív fajokkal erösen szennyezett területeken a vízáramlás sebessége 0 m/s-ra is lecsökkenhet (Nepf és Vivoni 2000, Sándor and Kiss 2007, Sándor 2011).

A hordalék a hullámtér egy adott pontjára történő szállítása attól függ, hogy milyen hidrológiai kapcsolat áll fenn az adott hullámtéri felszín és a folyó között (Kaase és Kupfer 2016). Ezt a kapcsolatot az árvizek nagysága, gyakorisága és hossza, valamint az árhullám útjában lévő, érdességet növelö objektumok térbelisége határozza meg (Magilligan 1992, Asselman és Middlekoop 1995, Asselman és Middlekoop 1998, Walling és He 1998, Kroes és Hupp 2010, Opperman et al. 2010, Tang et al. 2014).

Az árvíz az ártérre kilépve szétáramlik, és mivel az ártéren a vízoszlop magassága kisebb, mint a mederben, a víz elveszti a hordalék továbbszállításához szükséges energiája egy részét, ami a hordalék akkumulációját okozza (Happ et al. 1940, Brierley et al. 1997). Walling és He (1998) szerint az egységnyi területen lerakódó hordalék mennyisége arányos a felette elhelyezkedő vízoszlopban lévő összes hordalékmennyiséggel, amely pedig arányos a vízmélységgel. Az ártér magasan fekvő területei (pl. folyóhátak) csak a legmagasabb árvizek alkalmával tudnak épülni (Asselman és Middlekoop 1998). A nagy magnitúdójú árvizek során átlagosan közel 3-4-szer több hordalék halmozódhat fel, mint közepes és alacsony árhullámok alkalmával (Kaase és Kupfer 2016).

Steiger és Gurnell (2003) magas árvizek esetén a hordalék akkumulációjának két fó mintázatát írják le. Korlátozott körülmények között (pl. magasabb folyóhát megakadályozza, hogy a víz az ártér távolabbi területeire is eljusson) az árér és a meder között gyenge marad a kapcsolat, így a legtöbb hordalék a magasabb part menti sávban halmozódik fel. A másik 
esetben, amikor az árvíz akadálytalanul szét tud áramlani, az ártér távolabbi területein is előfordulnak vastagabb hordalékrétegek. Ezzel szemben alacsony árhullámok esetén az ártér és a meder között gyenge a kapcsolat, így legfeljebb a mederhez közeli területek töltődnek fel, míg más szerzők szerint (Asselman és Middlekoop 1998, Kaase és Kupfer 2016) az alacsonyabb és a lassan levonuló árhullámok is fontos szerepet töltenek be az alacsonyabb ártéri szinteken az agyag és az iszap szemcsék lerakódásában.

Asselman és Middlekoop (1998) szerint a legtöbb hordalék közepes vízhozamú árvizekkor rakódik le az ártéren, mivel a vízhozam növekedésével a vízáramlás elér egy olyan kritikus sebességet, amely megakadályozza a finom lebegtetett hordalékszemcsék felhalmozódását. A szerzők szerint ezért az árterek feltöltődésében sokkal fontosabb szerepet játszanak a közepes magnitúdójú árvizek, mint az extrém magas áradások. Durvább szemcseméretü hordalék (pl. homok) azonban a nagyobb sebességü áramlások esetén is felhalmozódhat. Sándor (2011) mérései szerint az ártér azon részein, ahol a vízáramlás sebessége nagyobb volt (pl. nyiladékokban, földutak mentén, vízvezető sávokban, tiszta sorközü ültetett erdőkben és a töltések lábánál) a hullámtér belsőbb területein nagyobb vastagságban is megfigyelhető volt a durva hordalékszemcsék akkumulációja. Nagy vízsebesség esetén azonban a víz akár hordalékot is elszállíthat az ártérről (elsősorban a part menti sávból), ami így csökkenti a felhalmozódás átlagos ütemét (Borsy 1972), és ez a hatás fokozódhat, ha a sodorvonal közel helyezkedik el a külső ívhez (Uddin és Rahman 2012).

Az elöntés magassága és az árhullám vízhozama mellett fontos tényező az elöntés gyakorisága is (Ross et al. 2004). Walling és He (1998) angliai folyók mentén végzett méréseik alapján megállapították, hogy a gyakrabban elöntés alá kerülő folyók árterén közel kétszer olyan gyors a hordalék felhalmozódása. Az árvizek gyakoriságát azonban csökkenthetik az antropogén beavatkozások. Magilligan (1985) a Wisconsin és Illinois államokban található Galena folyó mentén végzett kutatásai alapján megállapította, hogy az 1930-as években végzett szabályozások hatására a vízjárás mérséklődött, így az 1940-es évektől csökkent az árvizek gyakorisága, amely miatt az ártér feltöltődésének üteme a felére csökkent. Hasonló jelenséget figyelt meg Knox (1987) a Mississippi mentén.

\section{B) A medertől való távolság és ártérszélesség hatása a feltöltődésre}

Az ártéren lerakódó hordalék mennyiségét és szemcseösszetételét alapvetően befolyásolja a medertől mért távolság. A hullámtér hosszú-vagy rövidtávú feltöltődésével foglalkozó kutatások szinte kivétel nélkül kiemelték e tényezőnek a szerepét (Borsy 1972, Walling és He 1994, Asselman és Middlekoop 1995, Walling et al. 1997, Gönczy és Molnár 2004, Oroszi és Kiss 2004, Oroszi et al. 2006a, Sándor és Kiss 2007, Vass 2007, Omengo et al. 2016). A legdurvább szemcseösszetételü és legvastagabb hordalék a part menti sávban halmozódik fel, míg a finomabb szemcséjü (iszap és agyag) lebegtetett hordalék az ártér távolabbi területeire is eljut, de jóval kisebb vastagságban (Asselman és Middlekoop 1995, Sándor 2011). A hordalék hirtelen part menti felhalmozódásának oka a meder és a hullámtéri területek közötti vízsebesség-különbség (James 1985, Pizzuto 1987). Mivel a mederben gyorsabb a vízáramlás, mint a jóval sekélyebb és nagyobb érdességü hullámtéri területeken, a hullámtérre kilépő víz áramlási sebessége hirtelen lecsökken, ezáltal a víz hordalékszállító képessége is, amely a durvább szemcsék mederhez közeli nagy vastagságú felhalmozódását eredményezi.

A durvább hordalék felhalmozódásának medertől való távolsága folyónként igen eltérö, a legtöbb kutató 10-60 m szélességben mérte a legnagyobb üledékvastagságot (Marriott 1992, Ten Brinke et al. 1998, Szlávik 2001, Kiss et al. 2002), de egyesek ennél jóval szélesebb (190$350 \mathrm{~m}$ ) sávot határoztak meg (Oroszi et al. 2006ab, Oroszi 2008), amit utóbbiak a folyó nagyobb esésével magyaráztak. Azonban jelentős különbség lehet a kanyarulatok külső és belső oldala között, mivel a kanyarulatok belső ívén jóval távolabbra eljut a durvább lebegtetett hordalék, amelyet az övzátonyok kialakulásáért is felelős másodlagos helikoidális áramlásokkal magyaráztak (Kesel et al. 1974, Ten Brinke et al. 1998, Steiger és Gurnell 2003). 
A hordalék vastagsága exponenciálisan csökken a medertől mért távolsággal, a hullámtér távolabbi területein és az árvízvédelmi töltések lábánál csupán hártyavékony, minden esetben 1 cm-nél vékonyabb felhalmozódást mértek (Pizzuto 1987, Walling et al. 1997, Ten Brinke et al. 1998, Kiss et al. 2002, Vass 2007, Sándor és Kiss 2007, Geerling et al. 2008, Sándor 2011).

$\mathrm{Az}$ árterek feltöltődésére kiemelt hatással van az ártérszélesség is. Több szerző is megemlíti, hogy szűk ártéren kisebb térfogatú, de vastagabb, míg a széles ártéri szakaszokon nagyobb térfogatú, de vékonyabb hordalékréteg rakódik le (Magilligan 1985, Faulkner 1998, Ten Brinke 1998, Wyżga 1999, Gábris et al. 2002). Lecce (1997) az ártér szélességét a folyó munkavégző képességével együtt vizsgálta, hiszen véleménye szerint e két tényező egymással szoros összefüggésben van. Megállapította, hogy a szük ártéri szakaszokon megnő a vízáramlás sebessége, ezáltal erodáló képessége, így nagy mennyiségű hordalék nem tud felhalmozódni. Ugyanakkor a széles áréri szakaszokon azonban az árvíz oldalirányban szét tud terjedni, továbbá a víz sebessége is lecsökken, ami elősegíti az akkumulációt. Eredményei szerint az ártérszélesség 57\%-ban határozza meg az ártéren akkumulálódó hordalék mennyiségét és mintázatát, míg Magilligan (1985) 52\%-ban határozta meg az ártérszélesség szerepét.

\section{C) Az ártér-morfológia hatása a feltöltödésre}

A kutatások nagy része a medertől való távolság mellett az ártér-morfológiát emelik ki, mint az árterek feltöltődését leginkább befolyásoló tényezőt (Gretener és Strömquist 1987, Lambert és Walling 1987, Asselman és Middlekoop 1995, Kiss és Fejes 2000, Kiss et al. 2002, Oroszi és Kiss 2004, Hupp et al. 2015, Kaase és Kupfer 2016).

A legintenzívebben feltöltődő területek a kanyarulatok külső ívén fejlődő folyóhátak, és a belső íven kialakuló övzátonyok, amely a mederhez való közelségükből adódik (Nanson és Croke 1992). A medertől távolabb fekvő mélyebb ártéri felszínek (pl. kubikgödrök, elhagyott medrek) is intenzív hordalék-lerakódással jellemezhetők, de ezeken a területeken rendszerint csupán finom szemcséjü lebegtetett hordalék (iszap és agyag) halmozódik fel (Félegyházi 2008). Mivel a kisebb árvizek alkalmával a mélyebb fekvésü területek kerülnek először elöntés alá, így hosszabb idő áll rendelkezésre a hordalék lerakódására (Tamás és Kalocsa 2003), ezért ezek az ártérrészek sokkal gyorsabb ütemben töltődnek, mint az ártér más területei (Félegyházi 2008, Ishii és Hori 2016). Az ártér medertől távolabbi területein zajló feltöltődés kitüntetett helyei a holtágak (Oroszi és Kiss 2004, Hudson et al. 2008, Oroszi 2008, Ishii és Hori 2016), amelyek feliszapolódásának üteme azonban változó. Angliai folyók mentén például 3-71 mm/év (Lewis és Lewin 1983), az ausztrál Hunter folyó mentén 45-140 mm/év (Erskine et al. 1992), míg Franciaországban 0-26 mm/év ütemmel töltődnek a folyók menti holtágak (Cittero és Piégay 2009). Gagliano és Howard (1984) szerint az egykori medrek 100-1500 év alatt feltöltődnek, míg Toonen et al. (2012) elméleti modellje szerint ehhez néhány évszázad szükséges. Ezt azonban jelentősen módosíthatják az antropogén beavatkozások (Kroes és Hupp 2010), hiszen például a Maros mentén a 19. század közepén levágott kanyarulatok az árvízvédelmi töltések kiépítését követő 40-50 éven belül teljesen feltöltődtek (Oroszi és Kiss 2004).

A holtágak mellett intenzív feltöltődéssel jellemezhetők a sarlólaposok (Lewin és Ashworth 2014), a kubikgödrök (Hudson et al. 2008, Oroszi 2008), illetve a csatornák (Taylor és Owens 2009) is. A holtágak és a csatornák ezen kívül kiemelt hordalék-szállító ésakkumuláló szerepet töltenek be, hiszen lehetővé teszik, hogy az ártér távolabbi területein is nagyobb vastagságú hordalék akkumulálódjon (Oroszi 2008, Kaase és Kupfer 2016).

A mélyebb ártéri részek intenzívebb feltöltődése miatt az ártéren a magasságkülönbségek idővel kiegyenlítődnek, hiszen míg a mélyebb formákat a kisebb árvizek is elöntik, addig a magasabb formák (pl. folyóhátak) csak magasabb árvizek alkalmával tudnak fejlődni (Hupp et al. 2010) 


\section{D) Meder-és kanyarulatmorfológia hatása az árterek feltöltödésére}

A különböző kutatások arra engednek következtetni, hogy a meder (szélessége, sodorvonal helyzete) és az egyes kanyarulatok (fejlettség, görbületi sugár) tulajdonságai elsősorban a part menti sávban határozzák meg a felhalmozódott hordalék mennyiségét és mintázatát. Ez pedig elsősorban az övzátonyok és a folyóhátak fejlődését foglalja magába, hiszen a mederhez legközelebb ezek a formák helyezkednek el (Nanson és Croke 1992). A kanyarulatok és a meder tulajdonságainak feltöltődésre gyakorolt hatása azonban csak kevésbé kutatott.

A kanyarulatok kora meghatározza a hordalék felhalmozódására rendelkezésre álló időt, így a part menti hordalék-felhalmozódás vastagságát és ütemét is (Cazanacli és Smith 1998, Kiss et al. 2018a). A kanyarulatok fejlődési típusa (Daniel 1971, Strick et al. 2018) elsősorban a belső íven befolyásolja a hordalék felhalmozódását, így az övzátonyok épülésére van hatással. A különböző fejlödési típusba tartozó kanyarulatok eltérő mozgása hatással van a kialakuló övzátonyok morfológiai tulajdonságaira (Strick et al. 2018)

A kanyarulatok fejlettségével szoros kapcsolatban áll a kanyarulatok görbületi sugara $\left(\mathrm{R}_{\mathrm{c}}\right)$, amely alapvetően meghatározza a hordalék szétoszlását az ártéren (Hudson és Heitmuller 2003). A kanyarulatok mentén a legnagyobb felhalmozódást azok belső oldalán figyelték meg (Ten Brinke et al. 1998, Steiger et al. 2001, Steiger és Gurnell 2003), és jellemzően a kanyarulatok alsó harmadában, közvetlenül a kanyarulat csúcspontjától folyásirányban lefelé (Bathurst et al. 2002, Fiala 2002). Bathurst et al. (2002) ezt azzal magyarázza, hogy a kanyarulat felvízi részén az ártérre kilépő víznek túl nagy a sebessége ahhoz, hogy a hordalékát lerakja. Fiala (2002) nagyobb hordalék-felhalmozódást nemcsak a belső oldalon, hanem a kanyarulatok külső ívén is megfigyelt, amelyet Sándor (2011) mérései is megerösítenek. Ennek magyarázata, hogy minél kisebb görbületi sugárral rendelkezik egy kanyarulat, árvíz idején a víz annál nagyobb erővel jut ki az ártérre, így a hordalékot jóval szélesebb sávban képes lerakni, mint egy nagyobb görbületi sugárral rendelkező kanyarulat esetében (Fiala 2002).

A mederben kialakuló formák (pl. homokpadok) is hatással lehetnek a hullámtér feltöltődésére. Pierce és King (2008) például hegyvidéki vízfolyásokban vizsgálta a mederben kialakuló hordalékdugók és homokzátonyok ártér-felöltődésre gyakorolt hatását. A durvaszemü hordalékból és uszadékból álló hordalékdugók eltorlaszolva a medret igen intenzív, akár 40szer, míg a meder közepén kialakuló homokpadok csupán 3-5-ször gyorsabb ütemü feltöltődést eredményeznek az ártéren.

Egy-egy árvíz levonulását követően a mély mederszakaszok oldalán csuszamlásos folyamatok indulhatnak meg, amely révén anyag kerülhet vissza a mederbe (Kiss et al. 2002, Brooks 2005). Ennek üteme például az Alsó-Tisza mentén kisvizes időszakokban 40-50 cm/nap is lehet (Kiss et al. 2002). Emellett áradások alkalmával a nagy sebességü víz hordalékot ragadhat el az ártér felszínéröl (Borsy 1972), illetve intenzívebb eróziót okozhat az is, ha a sodorvonal közel helyezkedik el a külső ívhez (Uddin és Rahman 2012). Mindezek pedig végérvényben a felhalmozódott hordalék vastagságának, illetve a felhalmozódás átlagos ütemének csökkenését eredményezik.

\section{E) Az ártér növényboritottsága és a területhasználat hatása az árterek feltöltödésére}

A növényzet feltöltődésre gyakorolt hatása az ártéri felszín érdességének és az ártérre kiöntő víz áramlási viszonyainak és sebességének módosításán keresztül valósul meg (Corenblit et al. 2007, Osterkamp és Hupp 2010, Takuya et al. 2014, Devi és Kumar 2016). A sürü hullámtéri növényzet jelentősen lelassítja az áramló vizet, amely az intenzívebb hordalék akkumulációval (Sharpe és James 2007, Kim et al. 2015) párosulva csökkenti a hullámtér vízszállító-képességét (Chow 1959, Osterkamp és Hupp 2010). Ez pedig végeredményben a vízállások növekedéséhez, így fokozottabb árvízveszélyhez vezethet (Wang et al. 2015). 
A növényzet áramlási viszonyokra, ezáltal a feltöltődésre gyakorolt hatása összetett, hiszen ez függ a növényzet sürüségétől és magasságától, valamint alaktani és szerkezeti tulajdonságaitól (Chow 1959, Wang et al. 2015, Vargas-Luna et al. 2015). Minél sürübb a növényzet a hullámtéren, az áramló víz annál nagyobb akadályba ütközik, így nagyon sürü növényzet esetén a vízsebesség akár $0 \mathrm{~m} / \mathrm{s}$-ra is lecsökkenhet (Nepf és Vivoni 2000, Sándor és Kiss 2007), ami fokozza a hordalék felhalmozódását. A növényzet sürüségét nem csak a tövek száma határozza meg, hanem a levélzet is (Ree és Crow 1977, Järvelä 2004, Antonarakis et al. 2010), amely sürüsége fajonként (Antonarakis et al. 2010), illetve évszakonként is változhat (Burkham 1976, Coon 1998). A növényzet típusa (lágyszárú vagy fásszárú) is hatással van a felszín érdességére (Freeman et al. 2000), hiszen a lágyszárú növényzet árvízkor a vízáramlásnak megfelelő irányban meghajolhat, emiatt csökken a vízáramlás növényzettel szembeni ellenállása (Galema 2009). A növényzet okozta vízsebesség-csökkenés a növényzet magasságáig terjed, így fontos az is, hogy a hullámteret milyen magas vízoszlop borítja (Rátky és Farkas 2003). Ha az elöntés magassága meghaladja a növényzet magasságát, a növényzet felett a vízáramlás sebessége normalizálódik, hiszen nincs, ami lelassítaná (Galema 2009).

A növényzet kiemelt hatással lehet a hordalék felhalmozódására, bár ez még kevésbé kutatott. Steiger et al. (2001) a franciaországi Garonne folyón végeztek kutatásokat. Az általuk vizsgált 50 évben a feltöltődés üteme az ötszörösére gyorsult, amelyben jelentős szerepe lehet part menti növényzet sürübbé válásának. Ugyanitt végzett kutatásokat Steiger és Gurnell (2003), akik az akkumulálódott hordalék mennyiségét vizsgálták különböző felszínborítási kategóriákban. Eredményeik szerint a természetközeli sürübb ártéri erdőkben közel négyszer annyi hordalék akkumulálódott, mint a ritkább ültetett nyárerdőkben. Borsy (1972) a FelsőTisza mentén végzett kutatásai alapján meghatározta, hogy a sürübb növényzet (sürü bokrok, fák közelebb voltak egymáshoz) kedvezett a hordalék lerakódásának. Ezen akadályok mögött az árvizet követően 10-30 m hosszú formák jöttek létre. Sándor és Kiss $(2007,2008)$ pedig a Közép- és Alsó-Tisza hullámterén végzett kutatásaik alapján kimutatták, hogy a part menti növényzet sürübbé válása a hordalék-felhalmozódás ütemének megduplázódását eredményezte az 1960-as évek óta, amelyért elsősorban az invazív növényfajokat (pl. gyalogakác) tették felelőssé.

A klímaváltozáshoz kapcsolódóan napjainkban az ártéri ökoszisztémákban jelentős problémát okoznak a nem őshonos, inváziós fajok, amelyek gyors terjedésük miatt korlátozzák az öshonos fajok szaporodását és megújulását, ezáltal csökkentve a hullámtéri növényzet fajösszetételét (Didham et al. 2005), és jelentős mértékben növelve a növényzet sürüségét is (Delai et al. 2018). A folyók hullámtere optimális feltételeket biztosít az invazív fajok terjedéséhez, hiszen ezek a fajok egyrészt előnyben részesítik az időszakos elöntéseket, mivel magjaik a vízben tudnak a leghatékonyabban nagy távolságokra eljutni, megfertőzve további területeket (Pyšek and Prach 1994), jól türik a friss üledékkel való eltemetődést (Schnitzler et al. 2007) és a szélsőséges hidrológiai helyzeteket, kedvelik a sok napfényt (Dumitraşcu et al. 2014), és az emberi beavatkozások (pl. fajok behurcolása, erdőirtás) is elősegítik terjedésüket (Planty-Tabacchi et al. 1996). A hullámtéren belül elsősorban a felhagyott réteken és legelőkön, illetve parlaggá váló szántóföldeken tudnak a leggyorsabban elterjedni (Pyšek and Prach 1993, Szigetvári és Tóth 2012, Mihály and Botta-Dukát 2004). Planty-Tabacchi et al. (1996) kiemelte, hogy az invazív fajok az idősebb erdőállományokban is megtalálhatók, viszont legkönnyebben és legnagyobb mértékben a fiatal állományok fertőződnek meg. Délnyugat-Franciaországban és az USA-ban végzett kutatásaik alapján a hullámtéri erdőállományok 24-39\%-ban voltak invazív fajokkal fertőzöttek.

Az ártéri erdök különösen jó terepet kínálnak az invazív fajok terjedésének, hiszen az egyre magasabb és hosszabb árhullámok olyan zavaró hatásokat jelentenek, amelyeket az őshonos fajok már nem feltétlenül képesek elviselni (Catford and Jansson 2014, Garssen et al. 2015). Például a magyarországi Alsó-Tiszán az árterek 4-6 m-es vízoszloppal lehetnek borítva 1-3 hónapig, ami a gondozatlan erdőkben elősegítette például az invazív gyalogakác (Amorpha 
fruticosa), süntök (Echinocystis lobata) és parti szölö (Vitis vulpina) terjedését, amelyek napjainkra sok helyen összefüggő, áthatolhatatlan bozótost alkotnak (Delai et al. 2018).

A hullámterek vízvezetö-képességének, tehát az árvizek akadálytalan levonulásának biztosítása a hatékony árvízvédelem egyik legfontosabb feladata (Kozák és Rátky 1999, Samuels et al. 2002, Rátky és Farkas 2003). Egy jó vízszállító-képességgel rendelkező hullámtér közel hatszor annyi vizet képes szállítani, mint egy ugyanolyan széles, de rossz vízvezető-képességű hullámtér, miközben egy megfelelő a vízvezető képességü hullámtér akár 150\%-kal több vízhozamot képes szállítani árvizek alkalmával, mint a fömeder (Kozák és Rátky 1999). Azonban Kozák és Rátky (1999) számítási alapján a Tisza hullámtere jelenleg az árvízi vízhozamok legfeljebb 25\%-át vezeti le 1-5 m magas vízborítást és 200-1000 m széles hullámteret feltételezve. Megállapították azt is, hogy a nem megfelelően kezelt hullámtér egy nagyobb, $3000 \mathrm{~m}^{3} / \mathrm{s}$-os vízhozamot körülbelül 1,8 m-rel magasabb vízállás mellett képes csak elvezetni, mint egy sima felszínü hullámtér. Sándor (2011) vizsgálatai szerint a 2006. évi árvíz akkumulációja miatt a hullámtér vízvezető képessége az árvíz után 0,14-0,46\%-kal csökkent, de szükületekben és az inflexiós sávokban ennél jóval nagyobb, 1-1,5\%-os csökkenés is előfordult. Rátky és Farkas (2003) szerint a teljes nagyvízi meder vízszállítása javítható lenne a hullámtér vízszállításának javításával, amelynek megoldását a hullámtéri növényzet ritkításában látják. Számításaik alapján a Kisköre és Zenta közötti 280 km hosszú Tisza szakaszon az érdesség $\pm 30 \%$-os módosítása körülbelül 1,5 m-es szintkülönbséget eredményezne a vízállásokban. Rátky és Rátky (2009) szerint $30 \mathrm{~km}$ hosszú szakaszon a növényzeti érdességet a felére csökkentve 20-30 cm-rel alacsonyabban vonulnának le az árvizek. Kiemelték továbbá, hogy a növényzet foltszerü és rövidebb szakaszokon való kiirtása nem célszerü, mert ez az alsóbb szakaszokon a víz visszaduzzadását eredményezheti (Kiss et al. 2019c).

A hullámtér vízvezetö-képességének megváltozását a növényzet, tehát a felszín érdessége alapvetően befolyásolja (Rátky és Farkas 2003, Rátky és Rátky 2009). Az árterek érdességének megváltozását a felszínborítás/területhasználat megváltozása okozza, amely végbemehet természetes szukcessziós folyamatok révén is (Corenblit et al. 2007), de a legdrasztikusabb változásokat az antropogén hatásra történő területhasználat-változás okozza. Kozák és Rátky (1999) a hullámtér vízvezető képességének romlásáért a nyári gátak rendszerét és a nem megfelelő erdőgazdálkodást okolja. Az árterek beépítése, üdülők és turisztikai létesítmények kialakítása (Török 2000), az ártéren fennakadó uszadékfák (Gurnell és Gregory 1995), illetve az özönnövények megjelenése (Planty-Tabacchi et al. 1996) is növelik a felszín érdességét.

A vízgyüjtő növényzete és mezőgazdasági müvelése is befolyásolja az árterek vízvezető képességét, hiszen a folyókba bemosódó hordalék az ártereken rakódik le. Ez igen látványosan jelent meg az amerikai kontinensen és Ausztráliában, ahol az európai telepesek érkezése után indult meg az intenzív ártérfeltöltődés a vízgyüjtőn az erdők kiirtását követően (Costa 1975, Eyles 1977, Beach 1994, Wasson et al. 1998, Florsheim és Mount 2003, Ritchie et al. 2004, Knox 2006, Gell et al. 2009, Hughes et al. 2010, Hupp et al. 2015). A telepesek megérkezését követően több méter vastag üledékréteg fedte be a korábbi ártéri felszíneket (Lecce 1997), amelynek pontos vastagságát Magilligan (1992) $3 \mathrm{~m}$-ben határozta meg. A felhalmozódás üteme éghajlati területenként és vízfolyásonként meglehetősen eltérő, de általánosságban elmondható, hogy sok helyen a 2-4-szeresére növekedett (Florsheim és Mount 2003, Hughes et al 2010), de van ahol tízszeres növekedést is megfigyeltek (Gell et al. 2009).

\section{F) Antropogén beavatkozások hatása az árterek feltöltödésére}

A különböző antropogén hatások, úgymint a kanyarulatok átvágása, árvízvédelmi töltések kiépítése, illetve a mederben elhelyezett különböző létesítmények (duzzasztók, partbiztosítások és sarkantyúk) jelentős változásokat idéznek elő az árterek fejlődésében (Kesel 2003).

A kanyarulatok mesterséges átvágása a munkálatok elvégzését követően intenzív ártérfeltöltődést okoz (Biedenharn et al. 2000). A megnövekedett esés miatt nő a folyó munkavégző-képessége, ezáltal a szállított hordalék mennyisége is, amely a hullámtéren 
lerakódva annak gyors feltöltődését eredményezi (Károlyi 1960, Biedenharn et al. 2000, Tiron et al. 2009). Ezt a folyamatot felgyorsította a hazai mederszabályozási gyakorlat, amely során csupán vezérárkokat ástak, és azt (leginkább) a folyó erodálta megfelelő méretü mederré. A folyamat következtében nagyon nagy mértékben megnőtt a folyók hordalékhozama, amire bár konkrét mérési adatok nincsenek, de ekkor vált csupán $1 \mathrm{~m}$ méllyé a Maros-Tisza torkolatnál a Tisza, és gázlók sokasága jött létre (Iványi 1948), illetve néhány évtizeden belül csaknem teljesen feltöltődtek a Maros levágott medrei (Oroszi és Kiss 2004).

A feltöltődés üteme idővel azonban lelassulhat, amelynek Wyżga (2001) három okát különböztette meg: (1) A kanyarulat-átvágások hatására felgyorsult vízsebesség megkönnyíti a lebegtetett hordalékszemcsék szállítását, így megakadályozza azok felhalmozódását. (2) A meder bevágódásának fokozódásával nő a meder és az ártér közötti relatív magasságkülönbség, így adott vízállás csak egyre nagyobb vízhozamok mellett érhető el, ezáltal csökken az elöntések gyakorisága (Steiger et al. 2001, Steiger és Gurnell 2003). Végül (3) a durvább szemcséjü lebegtetett hordalék a mederben a vízoszlop felső része felé fokozatosan csökken. A bevágódás következtében mélyül a meder, így ezek a szemcsék már nagyrészt a mederben szállítódnak, míg az ártérre már csak a legapróbb hordalékszemcsék jutnak ki.

Az árvízvédelmi töltések a síkvidéki vízfolyások árterét jelentősen leszükítették. Ennek következtében a töltések kiépítését követően megnőtt a hullámtérre kiöntő árvizek magassága (Kvassay 1902, Rakonczai és Kozák 2009), illetve a lebegtetett hordalékmennyiség ezen a jóval szükebb hullámtéren halmozódott fel (Károlyi 1960, Asselman és Middlekoop 1995, Nagy et al. 2001, Schweitzer 2001, Hudson et al. 2008). Mindez a feltöltődés intenzívebbé válását (Károlyi 1960, Jakucs 1982, Nagy et al. 2001, Sándor és Kiss 2006ab, 2007), végérvényben pedig a hullámterek vízvezető-képességének romlását eredményezte (Kozák és Rátky 1999, Nagy et al. 2001, Vágás 2001, Samuels et al. 2002, Rátky és Farkas 2003, Osterkamp és Hupp 2010). Az ártéri felszín és az aktív meder közötti magasságkülönbség növekedése tehát nem csak a meder bevágódásával, hanem az ártér feltöltődésével is kapcsolatba hozható. Mivel a feltöltődés elörehaladtával már csak a magasabb árvizek képesek felhalmozni hordalékukat, így a feltöltődés üteme lelassul (Ten Brinke et al. 1998, Steiger et al. 2001). Az árvízvédelmi töltésekhez hasonlóan az ártéren lévő utak és vasútvonalak töltése is növeli az elöntések magasságát, így fokozva a feltöltődést (Garcia et al. 2015).

A völgyzárógátak a folyók alvízi szakaszán a feltöltődés mértékének csökkenését eredményezik (Renshaw et al. 2014). Marren et al. (2014) ennek két okát különböztette meg: A duzzasztók egyrészt csökkentik az alsóbb szakaszokon az elöntések gyakoriságát, hosszát és magasságát, így a hordaléknak rövidebb idő áll rendelkezésre a felhalmozódásra (Williams és Wolman 1984, Magilligan és Nislow 2005). Másrészt csökken az alsó szakaszokra jutó hordalékmennyiség is, hiszen a duzzasztótérben halmozódik fel az a lebegtetett hordalékmennyiség, amely ellenkező esetben az ártéren akkumulálódna (például a Nílus hordalékhozamának 98\%-a csapdázódik a Nasser-tóban; Gupta 2007).

A mederben létesített partbiztosítások és sarkantyúk a part eróziójának mérséklését és a hajózási útvonal biztosítását szolgálják (Ihrig 1973). Henning és Hentschel (2013) szerint a hordalék-felhalmozódás mintázatát és ütemét bizonyos mértékig a sarkantyúk típusa és a hozzájuk kapcsolódó vízáramlások is befolyásolják. Ten Brinke et al. (1998) szerint pedig ezek a partvédő müvek csökkentik az ártérre kijutó hordalék mennyiségét, azáltal hogy szétoszlatják az áramlások energiáját. A kanyarulatok külső ívén épített partbiztosítások elsősorban a hordalék horizontális akkumulációját, azaz az övzátonyok épülését befolyásolja. A partok kőrakatokkal való stabilizálása a külső ív eróziójának lassulását/megállását eredményezi. Ez egyrészt csökkenti a mederben a külső ív eróziójából származó hordalékmennyiséget, amely hatására az ártereken is kevesebb anyag tud felhalmozódni (Kesel 2003). Másrészt módosítja a belső íven épülö övzátonyok fejlödését is. Kiss et al. (2018a, 2019b) az Alsó-Tiszán végzett vizsgálataik alapján kimutatták, hogy az 1930-as évek óta kiépített partbiztosítások hatására az aktívan épülő övzátonyok száma a felére (47-röl 20-ra), összhosszuk pedig a tizedére $(52,3 \mathrm{~km}$ ről 4,7 km-re) csökkent, illetve a meder bevágódása miatt megindult azok eróziója is. 
Az árterek feltöltődését befolyásoló tényezők eddigi vizsgálatai alapján elmondható, hogy az árterek feltöltődését, a hordalék felhalmozódásának mértékét, ütemét és mintázatát számos tényező befolyásolja, amelyek rendszerint nem külön-külön befolyásolják a feltöltődést. Hatásuk egyszerre is érvényesülhet, így egymás hatását felerösíthetik, vagy éppen ki is olthatják. A hazai kutatások azonban ezen tényezőknek csupán kis hányadával foglakoztak részletesen, a vizsgálatok többsége elsősorban az ártér/hullámtér topográfiai viszonyainak, a medertől való távolság és az árvizek hidrológiai viszonyainak, és a növényzet feltöltődésre gyakorolt hatását vizsgálták, és nem foglakoztak például a meder és a kanyarulatok jellemzőinek részletesebb vizsgálatával. Emellett a kutatások pontszerüek voltak és csak ritkán tüzték ki célul a teljes hullámtéren tapasztalható hordalék-felhalmozódás vizsgálatát, és nem foglalkoztak a folyóhátak és övzátonyok fejlődését befolyásoló tényezőkkel, holott e két forma a vertikális és az oldalirányú felhalmozódás kitüntetett helyei.

\subsubsection{A hullámtéri feltöltődés vizsgálatának lehetséges módszerei}

$\mathrm{Az}$ árterek feltöltődésének mértéke és üteme különböző módszerekkel vizsgálható. A hosszútávú mérések a hordalék felhalmozódásnak néhány tíz évestől (Álvarez-Iglesias et al. 2007, Geerling et al. 2008, Provansal et al. 2010) egészen a több száz éves (Florsheim és Mount 2003, Wallinga et al. 2010, Hupp et al. 2015) változását is vizsgálják. Ezzel szemben a rövidtávú mérések néhány éves időszak (Hupp et al. 2008, Pierce és King 2008, Kaase és Kupfer 2016), illetve egy-egy árvízi esemény eredményeként felhalmozódó hordalék mennyiségét és mintázatát vizsgálják (Asselman és Midlekoop 1985, Oroszi 2006ab, Sándor és Kiss 2007).

\section{A) A hosszú távú ártérfeltöltödés mérésének módszerei}

A hosszú távú feltöltődést elsősorban elsősorban az ártéren felhalmozódott üledék szedimentológiai vizsgálatán alapul (Florsheim és Mount 2003, Xu 2003, Provansal et al. 2010). A fúrásszelvényekböl vett minták alapján a kutatók az üledékek fizikai és kémiai jellemzőit, illetve korát vizsgálják. Az üledékprofil elemzésével nem csak az akkumulálódott hordalék vastagsága határozható meg, de a felhalmozódás ütemében bekövetkező változások is nyomon követhetők (Provansal et al. 2010). Erős antropogén hatásokkal befolyásolt vízfolyások mentén az emberi hatásra felgyorsuló ártérfeltöltődés mértékének meghatározására alkalmasak a paleotalajok, amelyek az antropogén hatások elött keletkeztek az adott területen (Knox 1987, Lecce 1997, Balogh et al. 2005). Ezek a talajrétegek színükben, illetve textúrájukban is eltérnek a folyóvízi üledékektől, jellemzően sötétebb színűek, kötöttebb szerkezetűek, és magas a szervesanyag-tartalmuk, míg a fluviális üledékek világosabbak, lazább szerkezetüek és jellemző rájuk a rétegzettség (Lecce 1997). Ezért a paleotalaj korának, illetve az azt befedő folyóvízi hordalék vastagságának ismeretében megállapítható az ártérfeltöltődés mértéke és üteme.

Nagyon gyakori módszer a hosszabb távon lerakódott hordalék mennyiségének és az akkumuláció ütemének meghatározásában az ártéri üledékekben előforduló nehézfémek és radioaktív anyagok koncentrációjának vizsgálata, amely hazánkban is gyakran alkalmazott módszer (Nagy et al. 2001, Sándor és Kiss 2006ab, Dezső et al. 2009). Lényege, hogy bizonyos nehézfémeknek (pl. ólom, réz, cink, króm, arzén) és radioaktív anyagoknak ismert a folyóvízi rendszerekbe és a légkörbe jutásának időpontja/időszaka, így markerrétegként felhalmozódtak a hullámtéri üledékekben (Pizzuto et al. 2016). Mivel ezek a szennyezőanyagok az üledékek szemcséihez erősen kötődnek, így jól alkalmazhatóak a hosszútávon felhalmozódott hordalék mennyiségének és az akkumuláció ütemének meghatározására (Walling és He 1999, Matisoff 2014). A hullámtéri üledékekben felhalmozódott nehézfémek jellemzően lokális szennyezések során jutnak be a folyóvízi rendszerekbe, rendszerint a bányászat során létrehozott meddőhányók anyagából (Marron 1992, Hudson-Edwards et al. 1999, Bain és Brush 2005), illetve ipari tevékenység eredményeként (Hindel et al. 1996, Dawson 1997, Martin 2000, 
Kaushik et al. 2001). Ezért ezen ipari tevékenységek történetének (pl. mikor volt a termelés csúcsa), vagy nagyobb ipari balesetek idejének ismerete alapján pontosan megadható az ártérfeltöltődés mértéke. Ciszewski és Grygar (2016) kiemelték, hogy az ártéri üledékekben felhalmozódott nehézfémek mennyisége térben igen változatos lehet, amely pedig hatással van a mérés pontosságára és eredményére. Egyrészt (1) az áradások során a szállított hordalék (amelyekhez a szennyezőanyagok kötődnek) szemcseméret szerint osztályozódnak, illetve a vízgyüjtő más területeiről érkezett szennyezőanyagokkal keveredhetnek. Továbbá (2) az aktív folyóvízi rendszerekben a szennyezőanyagok jóval könnyebben mobilizálódnak (pl. parterózió következtében), mint a talajokban felhalmozódott anyagok. Végül (3) a mesterséges létesítmények és kanyarulat-átvágások is hatással vannak a nehézfémek felhalmozódására, ugyanis a tározóterekben, a sarkantyúk mögött és a nehézfémmel való szennyeződés időszaka elött levágott kanyarulatok medrében jóval több és nehezebben mobilizálódó nehézfém akkumulálódhat. A leggyakrabban vizsgált radioaktív anyagok a ${ }^{137} \mathrm{Cs}$ és ${ }^{210} \mathrm{~Pb}$, amelyek elsősorban az atombomba-kísérletek időszakában jutottak a légkörbe 1955 után, de koncentrálódásuk csúcsa 1963-ra tehető (He és Walling 1996), továbbá nagyobb mennyiségü radioaktív anyag került a légkörbe az 1986-os csernobili atomreaktor-balesetet követően (Walling és He 1999, Matisoff 2014). A ${ }^{210} \mathrm{~Pb} 100-150$ éves üledékek datálására alkalmas, míg a ${ }^{137} \mathrm{Cs}$ segítségével legfeljebb 40 évre visszamenőleg lehet vizsgálni az üledékek korát (Walling és He 1999, Walling et al. 2003). A ${ }^{137}$ Cs izotóp vizsgálatának azonban vannak korlátai, hiszen az egyenlítő környéki területeken és déli féltekén sokkal kevesebb ${ }^{137} \mathrm{Cs}$ halmozódott fel, mint az északi területeken (Garcia Agudo 1998). A természetesen előforduló ${ }^{210} \mathrm{~Pb}$-izotóp viszont alkalmasnak bizonyult e probléma kiküszöbölésére (Wallin és He 1999, Walling et al. 2003).

$\mathrm{Az}$ ártéri üledékek mágneses tulajdonságai is alkalmazhatók a feltöltődés mértékének meghatározására (Sándor és Kiss 2006b, Sándor 2011). Az üledékek mágneses érzékenysége (szuszceptibilitása) azt mutatja meg, hogy az üledékekben lévő anyagok mennyire mágnesezhetők, ha egy mágneses mezőbe kerülnek (Waythomas 1991). Egyes üledékek mágneses szuszceptibilitása függ az üledékekben jelen lévő ferromágneses ásványok koncentrációjától (Gomez et al. 1999), ezen anyagok méretétől és alakjától (Mullins 1977), az üledékek szemcseméretétől (Thompson és Morton 1979), illetve magának a mérésnek a módszerétől is (Mullins 1977). Ezen mágnesezhető anyagok természetes módon is bekerülhetnek az üledékekbe, például különböző kőzetek eróziója által (Waythomas 1991), azonban jelentős mennyiség származhat a különböző antropogén tevékenységekből, például közúti közlekedésből (Petrovský et al. 2000), és ipari szennyvízből (Chudaničová és Hutchinson 2016), de a legjelentősebb forrást a fosszilis energiahordozók elégetése jelenti (Heller et al. 1998). A fentieken kívül az üledék mágneses tulajdonságait meghatározza a talajlakók biológiai aktivitása is, így alapvetően más mágneses tulajdonságokkal rendelkeznek az eltemetett talajok, a gyorsan vagy éppen lassan lerakódó folyóvízi hordalékok (Sándor 2011).

$\mathrm{Az}$ ártéri üledékekben lévő pollenek vizsgálata is alkalmas a hossztávú feltöltődés meghatározására. Az üledékek pollenspektrumának elemzésével jól vizsgálható egy adott terület növénytársulásának megváltozása (Clark 1986). Az ártéri üledékek esetén a különbözö inváziós fajok pollenjei kronosztratigráfiai markerként használhatók, így segítségükkel meghatározható a megjelenésüket követő feltöltődés (Kenyon és Rutherfurd 1999, Oroszi és Kiss 2004, Gell et al. 2009, Kiss et al. 2011, Hupp et al. 2015). Az antropogén hatások eredményeként intenzívebbé váló hordalék-felhalmozódás is vizsgálható palynologiai módszerekkel, hiszen például a földművelés megindulása vagy erdőirtás után az eredeti növénytársulásokat felváltják a mezőgazdasági kultúrák (Mücher et al. 1990, Baker et al. 1993, Kenyon és Rutherfurd 1999). A pollenanalitikai vizsgálatok feltétele, hogy ismert legyen az egyes növényfajok megjelenésének pontos időszaka (Constantine et al. 2005). Az ártéri üledékekben lévő pollenek összetételét azonban számos dolog befolyásolhatja, amelyek a mérések pontatlanságához vezethetnek. Az árvizek a vízgyüjtő más területiröl a vizsgált helyszínre szállíthatnak olyan polleneket, amelyek idősebbek, mint az általunk vizsgálni kívánt 
pollenszemcsék (Pennington 1979). Az áradások rendszerint átdolgozzák, illetve erodálják az üledékeket, amely eredményeként a pollenek keveredhetnek, illetve károsodhatnak (Clark 1986, Constantine et al. 2005).

A radiokarbon kormeghatározással az üledékekben lévő szervesanyag-tartalom mérhető (Constantine et al. 2005), így ez a módszer az ártereken belül elsősorban a holtágak feltöltődésének vizsgálatára alkalmas (Félegyházi 2008, Ishii és Hori 2016), illetve az ártéri üledékek alatt elhelyezkedő paleotalajok korának meghatározása is elvégezhető vele (Knox 1987). A módszer hátránya, hogy fiatal (<200 éves) folyóvízi üledékek kormeghatározására kevésbé alkalmas (Rustomji és Pietsch 2007, Gell et al. 2009), illetve a mérések során számos tényező befolyásolhatja az üledékminta korát. Fontos, hogy idegen szén ne kerüljön a vizsgálandó mintába, amely azonban számos forrásból származhat, például a növények gyökérzetéböl, korhadt uszadékfákból, de a levegö széntartalma is téves kor megállapításához vezethet (Terasmae 1984). Amintába került 1\%-nyi fosszilis szennyezöanyag akár 80 évvel fiatalabb kort is eredményezhet (Svingor 2012).

Az optikailag stimulált lumineszcencia (OSL) módszerének segítségével az üledékekben található kvarc- és földpátszemcsék eltemetődésének ideje határozható meg, azaz, hogy az adott szemcsét mikor érte utoljára napsugárzás (Wallinga 2002, Hobo et al. 2010, Wallinga et al. 2010). Ezt a módszert egyre több kutatás alkalmazza az ártérfeltöltődés mértékének és ütemének számszerüsítésére (Rustomji és Pietsch 2007, Gell et al. 2009, Hughes et al. 2010, Wallinga et al. 2010, Sümeghy et al. 2013, Hernesz et al. 2015). A módszer nagy elönye a radiokarbon kormeghatározással szemben, hogy nagyon fiatal $(<200$ év) üledékek meghatározására is alkalmas (Rustomji és Pietsch 2007). Fiatal folyóvízi üledékek esetében azonban előfordulnak olyan tényezők, amelyek a minták korának túl- vagy alulbecslését eredményezhetik. A hordalékszemcsék vízben való szállítódása során előfordulhat, hogy a kvarc- és földpátszemcsék csak részlegesen nullázódnak (Wallinga 2002, Hughes et al. 2010), vagy az ártéren felhalmozódott hordalékszemcsék a lerakódásuk előtt nem ürülnek ki teljesen, így a szemcsékben maradhat lumineszcens jel, emiatt pedig a minta idősebbnek adódhat a valódi koránál (Hobo et al. 2010, Sümeghy 2014).

A dendro-geomorfológia szintén alkalmas módszer az árvizek és a feltöltődés meghatározására. Olyan vízfolyások mentén, ahol nincsenek rendszeres vízállás mérések, a fák évgyürüinek és sebeinek vizsgálata pontos és megbízható adatokkal szolgálhat egy adott árvíz magasságára és kialakulásának időpontjára vonatkozóan (Strunk 1997, Hupp és Bornette 2003, Lang 2008, Hupp et al. 2015). A hordalék-felhalmozódás mértéke és üteme az eltemetett fatörzsek alapján határozható meg. Amennyiben az árvíz és az eltemetődés során a fa elpusztul, de a legkülső évgyürüje megmarad (a hánccsal együtt), akkor meghatározható a fa elpusztulásának ideje, amely megadja a hordalék-lerakódás maximális korát (Lang 2008). Élő fa törzsének részleges eltemetődése során pedig a fák gyökerei is tükrözik a hordalék felhalmozódásának folyamatát (Provansal et al. 2010, Pizzuto et al. 2016), ugyanis az akkumulációt követően az új hordalékréteg legfelső szintjében ún. járnokgyökerek képződhetnek, amelyek kora megadja kialakulásuk idejét, így következtethetünk az akkumuláció ütemének változására (Strunk 1997, Kiss és Sipos 2009).

Egyes kutatások nem a felhalmozódott hordalék anyagát, hanem az általa létrehozott kiemelkedő formát vizsgálták különböző térképek és az ezekből készített digitális domborzatmodellek alapján, és így határozzák meg a feltöltődés mértékét. A módszer elsősorban árvízvédelmi töltésekkel leszükített vízfolyások mentén alkalmazható, hiszen az árvízvédelmi töltések kiépítése után felhalmozódó hordalék a hullámtéri felszín magasságnövekedését eredményezte, míg a mentett ártéri területek magassága - erőteljes bolygatás hiányában - változatlan marad. Tehát a leszükített hullámtéri és a mentett ártéri területek magasságkülönbsége alapján meghatározható a töltések kiépítése óta felhalmozódott hordalék vastagsága és térfogata. Egyes kutatók ezt a magasságkülönbséget saját mérések alapján, szintezés segítségével határozták meg (Gönczy és Molnár 2004, Vass 2007), míg mások digitális domborzatmodelleket alkalmaztak (Gábris 2002, Kiss et al. 2011). Utóbbi 
hátránya, hogy a digitális domborzatmodell nagy vertikális pontatlansága hibás eredményekhez vezethet, ugyanakkor nagy területen teszi lehetővé a feltöltődés mértékének meghatározását, szemben a pontszerü szedimentológiai módszerekkel, vagy a szelvények mentén történö térképezéssel.

A hidraulikai modellekkel a vízáramlás sajátosságai, azaz az ártérre szállított hordalék esetleges leülepedésének körülményei vizsgálhatók a különböző tényezők (pl. domborzat, növényzeti érdesség) beépítésével, amelyből következtetni lehet a hordalékszállítási folyamatokra és a feltöltődés sajátosságaira (Rustomji és Pietsch 2007, Garcia et al. 2015, Kiss et al. 2019b). A legegyszerübb modellek alapfelvetése, hogy az árterek feltöltődésének üteme arányosan változik a vízhozammal, tehát minél nagyobb az árteret elöntő árvíz vízhozama, annál nagyobb mennyiségű hordalék képes felhalmozódni (Geerling et al. 2008). Ezt a feltevést azonban Asselman és Middlekoop (1985) kutatásai cáfolják, miszerint a legtöbb hordalék közepes vízhozamú árvizek során képes lerakódni. Koncsos és Kozma (2007) egyszerüsített ülepedési modellt alkalmazott a Tisza menti hullámtér feltöltődésének modellezésére, amelynek alapja az a feltevés volt, hogy az árvizek tartóssága és a kiülepedő hordalék mennyisége között egyenes arányosság van.

Az árterek hosszú távú feltöltődésének meghatározásához alkalmazott különböző módszerek mindegyikénél előfordulnak olyan tényezők, amelyek a mérések pontatlanságához vezethetnek. Ennek kiküszöbölésére számos kutató a különböző módszereket egyszerre alkalmazza, így azok eredményei vagy kiegészítik egymást, vagy a módszerekből adódó pontatlanságokat lehet így kiküszöbölni (Rustomji és Pietsch 2007, Geerling et al. 2008, Gell et al. 2009, Hobo et al. 2010, Provansal et al. 2010, Hupp et al. 2015, Pizzuto et al. 2016).

\section{B) A rövid távú ártérfeltöltödés mérésének módszerei}

A hosszú távú mérések mellett számos példát találunk a feltöltődés rövid távú mérésére (Gretener és Strömquist 1987, Lambert és Walling 1987, Asselman és Middlekoop 1995, Walling et al. 1997, Wyżga 1999, Kiss és Fejes 2000, Kiss et al. 2002, Gönczy és Molnár 2004, Sándor és Kiss 2006a, Vass 2007, Hupp et al. 2008, Vass et al. 2009a). Az egy-egy árvízi esemény után felhalmozódó hordalék vastagságának, mennyiségének, illetve fizikai és kémiai tulajdonságainak vizsgálatával képet kaphatunk az ártereken zajló recens folyamatokról és azok változásáról.

Az árvizek során történő felhalmozódás mérése különböző módszerekkel történhet. Számos kutatás különféle természetes és mesterséges szintjelzö rétegeket használt a hordalék vastagságának és mennyiségének mérésére. A friss üledék színe és szerkezete alapján jól elkülönül az idősebb üledékektől (Kesel et al. 1974, Kiss és Fejes 2000, Steiger et al. 2003, Oroszi et al. 2006ab, Sándor és Kiss 2007). Az öszi időszakban felhalmozódott avartakaró felszínén a következő áradás során felhalmozódott hordalék vastagsága jól vizsgálható (Walling et al. 1997, Kiss és Fejes 2000, Kiss et al. 2002, Oroszi et al. 2006ab, Sándor és Kiss 2007, Vass 2007, Oroszi 2008). Erre a célra az ártéren lévő utak és betonfelszínek is alkalmasak, viszont ezek eloszlása az ártéren nem egyenletes (Kiss et al. 2002, Sándor és Kiss 2007, Vass 2007). A módszer előnye, hogy elökészületeket nem igényel és sok ponton mérhető a feltöltődés, viszont nem alkalmazható szántó- és gyepterületeken az avartakaró hiánya miatt (Pease et al. 2007), illetve az áradás a száraz leveleket elmoshatja (Steiger et al. 2003). Számos kutatás az ártér felszínére kijuttatott szintjelző anyagok segítségével vizsgálja az akkumulációt, amely lehet például szénpor vagy porított földpát (Pierce és King 2008, Schenk et al. 2013, Kaase és Kupfer 2016), míg Hupp et al. (2008, 2015) agyagréteget használtak. Véleményem szerint azonban ez csak akkor használható, ha a vizsgált vízfolyás az agyagnál nagyobb szemcseméretü hordalékot szállít, így kizárható a folyó által lerakott agyagréteg összetévesztése a mesterséges agyagszinttel.

Egyes kutatók az ártér felszínére kihelyezett hordalékcsapdákat alkalmaznak. A müfü segítségével például a természetes ártéri felszínt és annak érdességét célozták szimulálni (Lambert és Walling 1987, Asselman és Middlekoop 1995, 1998), míg mások különböző fából és műanyagból készült lemezeket (Gretener és Strömquist 1987, Gönczy és Molnár 2004), illetve 
tetőcserepeket (Steiger et al. 2001, Steiger és Gurnell 2003) alkalmaztak. Vass et al. (2009b) egy saját fejlesztésủ csapdával mérte a lebegtetett hordalék mennyiségét a felszíntől mért 10-40 cm-es magasságban. A különböző mesterséges szintjelző rétegek és üledékcsapdák hátránya, hogy az árvizek során olyannyira betemetődhetnek, hogy megtalálásuk nehézkes lehet, illetve az árvíz elmoshatja öket (Steiger et al. 2003, Pierce és King 2008).

A felszínbe szúrt akkumulációs tük is alkalmasak a felhalmozódott hordalék vastagságának mérésére (Steiger et al. 2003). A módszer lényege, hogy a vizsgált árvíz elött és annak levonulása után megmérjük a tük felszínből kiálló részének hosszát, és a kettő különbsége megadja az akkumuláció mértékét. Előnye, hogy nem csak a felhalmozódás, de az erózió mértéke is mérhető vele (Ghimire et al. 2013, Arnold és Toran 2018). Továbbá ez egy meglehetősen költséghatékony módszer, hiszen egyszerü szögvasakat kell a felszínbe szúrni, bár Pierce és King (2008) PVC csöveket alkalmazott erre a célra. Hátránya, hogy a tük által keltett turbulens áramlások módosíthatják az üledék vastagságát (Steiger et al. 2003).

A vízfolyások felvízi és egy alvízi szakasza között a lebegtetett hordalékhozamban bekövetkező csökkenés mérése alapján is lehet következtetni az ártérfeltöltődés mértékére, hiszen meghatározható az adott területen lerakódó anyag mennyisége (Walling et al. 1986, Lambert és Walling 1987, Walling és Bradley 1989). Ugyanakkor ez a módszer jelentős bizonytalanságokat hordozhat, részben a mérések nem megfelelö gyakorisága, részben a két mérési pont között lejátszódó, a lebegtetett hordalékhozamot befolyásoló egyéb tényezők (pl. parterózió) miatt (Sándor 2011).

Nagyobb térbeli léptékủ vizsgálatokra a távérzékelés (pl. Landsat 5 TM) is felhasználható az egy-egy áradás során felhalmozódó hordalék mérésére (Mertes 1994, Magilligan et al. 1998), hiszen a távérzékelt adatokkal mérhető az ártéren áramló vízben a lebegtetett hordalék koncentrációja, amely alapján következtetni lehet az üledék vastagságára (Magilligan et al. 1998). Az árvizet követően Ten Brinke et al. (1998) légifelvételek segítségével vizsgálták az ártéren lerakódott homokrétegek kiterjedését, amelyeket a környezetüknél világosabb, sárgás színe alapján azonosítottak. Ezen vizsgálatok legnagyobb hátránya a felbontásban rejlik, hiszen a felhalmozódott hordalék mintázata igen változatos lehet az ártéren. Más kutatók pedig földradar segítségével határozták meg a frissen felhalmozódott üledékek vastagságát (Ferguson és Brierley 1999, Bristow et al. 1999). Minden távérzékelést vagy georadart alkalmazó kutatás esetében szükség volt azonban az akkumuláció illetve a lebegtetett hordalék terepi vizsgálatára is, hiszen a felvételek interpretációit igazolni kellett.

\subsection{A feltöltődés kitüntetett helyei: a folyóhátak és az övzátonyok}

Az ártereken két fö hordalék-felhalmozódási folyamat jellemző: a vertikális és az oldalirányú (laterális) akkumuláció (Challinor 1946, Jahns 1947, Wolman és Leopold 1957, Nanson és Croke 1992). A vertikális hordalék-felhalmozódás a hullámterek domináns folyamata, amely során az ártérre kilépő víz a hullámtéren lerakja hordalékát és annak magasságát folyamatosan növeli (Coleman 1969). A vertikális felhalmozódás kitüntetett zónája a part menti sáv, illetve azon belül a folyóhátak területe (Wolman és Leopold 1957, Szlávik 2001, Sándor és Kiss 2006a). A laterális akkumuláció során az ártér az övzátonyok fejlődése, a mederszükülés és részben a holtágak feltöltődése révén gyarapszik (Wolman és Leopold 1957, Dietrich és Smith 1983, Nanson és Hickin 1983), így ebben a feltöltődési formában nincs szükség mederkitöltő szintet meghaladó vízállásokra, hiszen a folyamatok akár kis- és középvíznél is lejátszódhatnak. A két ártér-feltöltődési folyamat aránya helyről helyre változik. Például Wolman és Leopold (1957) és Leopold et al. (1964) szerint a vertikális feltöltődés során felhalmozódó hordalék csak csekély részét képezi a hullámtereket felépítő anyagnak, így a kanyarulatvándorlást és az ezzel együtt járó oldalirányú hordalék-felhalmozódást jelölték meg az árterek domináns folyamatának. A vertikális akkumuláció alárendelt szerepére az egy-egy árvíz során lerakódó kis átlagvastagságú üledékből következtetett, amelyet egyrészt azzal magyaráztak, hogy (1) a laterális erózió segít szabályozni az ártér magasságát, másrészt (2) a nagyobb vízhozamok rendszerint kisebb koncentrációjú 
lebegtetett hordalékot szállítanak, mint a kisebb vízhozamú árvizek. Végül (3) az ártéren áramló víz képes lehet elszállítani az ott felhalmozódott hordalék egy részét, amely végső soron csökkenti az ártér átlagmagasságát. Tanulmányaikban elsősorban olyan vízfolyásokat vizsgáltak, amelyek nem voltak szabályozva, így fejlődésük természetes körülmények között zajlott. Azonban a folyómedrek szabályozása, az árterek árvízvédelmi töltésekkel való mesterségesen leszükítése, és a területhasználat megváltozása a hordalék vertikális felhalmozódását felgyorsítják, így ez válik a domináns folyamattá (Lewin 1978, Magilligan 1992, Sándor és Kiss 2008, Oroszi 2009, Kiss et al. 2018a).

A két fajta felhalmozódás azonban ugyanazon helyen is előfordulhat (Magilligan 1992), például az egykori folyókanyarulatok övzátonyainak horizontális fejlödése a kanyarulatok természetes átszakadása vagy mesterséges levágását követően leáll, az ártér részévé válnak, így felszínükön megindul a hordalék vertikális felhalmozódása (Sándor és Kiss 2006b).

A következőkben a két hordalék-felhalmozódási folyamat kitüntetett helyeit, a folyóhátak (vertikális feltöltődés) és az övzátonyok (horizontális feltöltődés) fejlödésének folyamatát és az azokat befolyásoló legfontosabb tényezőket mutatom be részletesen. Bemutatásukat kiemelten fontosnak tartom, hiszen az épülésüket befolyásoló bármely tényező (pl. vízhozam, hordalékhozam, medermélyülés, értéri növényzet) megváltozására érzékenyen reagálnak, amely morfometriájukban is tükröződhet.

\subsubsection{A folyóhátak épülése és a fejlödésüket befolyásoló tényezök}

A vertikális akkumuláció kiemelt formái folyóhátak, amelyek elsősorban a kanyarulatok külső (konkáv) oldalán, illetve az egyenes szakaszok mentén épülnek (Wolman és Leopold 1957, Allen 1965). Itt fontosnak tartom tisztázni, hogy a hazai szakirodalomban ezeket a formákat eltérő megnevezéssel illetik, egyes kutatásokban övzátonyként (Nagy et al. 2001, Szlávik 2001, Schweitzer et al. 2002), máshol parti hátként említik (Gábris 2002, 2016). Azonban több geomorfológiai tankönyv (Balogh 1991, Lóczy és Veress 2005) is folyóhátnak nevezi, így dolgozatom során én is ezt a megnevezést alkalmazom.

A folyóhátak elsősorban a meanderező vízfolyások kanyarulatainak külső ívén fejlődnek (Nanson és Croke 1992), de bármilyen medermintázatú folyó esetén elöfordulhatnak (Smith 1996, Brierley et al. 1997, Adams et al. 2004). Ezek a mederrel párhuzamos, hosszan elnyúló pozitív formák (Allen 1965, Nanson és Croke 1992, Brierley et al. 1997) árvizek idején fejlődnek, amikor a medréből kilépő víz a part menti érdesség-növekedés miatt hirtelen sebességét veszti és hordalékát lerakja (Happ et al. 1940, Allen 1965, Coleman 1969, James 1985, Pizzuto 1987, Brierley et al. 1997). Magasságuk közvetlenül a meder szélén a legnagyobb, és az ártér belsőbb területei felé fokozatosan csökken (Allen 1965). Anyaguk függ a szállított hordalék minőségétől (Happ et al. 1940), azonban általánosságban jellemző, hogy anyaguk durvább, mint a teljes árteret felépítő üledék szemcsemérete, de finomabb, mint a mederben szállított fenékhordalék (Brierley et al. 1997). Az árvizek apadó ágában finomabb hordalék is felhalmozódhat a felszínükön, elsősorban a medertől távolabbi felükön (Allen 1965, Cazanacli és Smith 1998, Nagy et al. 2001, Sándor 2011), így szerkezetük gyakran rétegzett (Zwoliński 1992). Épülésük üteme függ az árvizek gyakoriságától (Coleman 1969), tartósságától (Szlávik 2001), illetve magasságától is, hiszen az egyes áradások során egyre magasabb formákat idővel csak a legmagasabb árvizek képesek csak elönteni (Asselman és Middlekoop 1998, Steiger és Gurnell 2003, Kiss et al. 2018b).

A folyóhátak fontos szerepet töltenek be az árvizek során a hullámtér távolabbi részei felé kijutó víz-és hordalékmennyiség szabályozásában (Happ et al. 1940, Brierley et al. 1997, Nagy et al. 2001), hiszen a víz áramlásának irányát befolyásolják (Brierley et al. 1997). Ha az ártérre kiáramló vizet nem akadályozza semmi (jellemzően a folyóhát), akkor a hullámtér távolabbi területein is előfordulhatnak vastagabb, durva lebegtetett hordalékból álló felhalmozódások (Steiger és Gurnell 2003, Ross et al. 2004, Hupp et al. 2008). Az egyre magasabbá váló folyóhátak miatt azonban csak egyre magasabb árvizek tudnak kiönteni az ártérre (Zwoliński 
1992), így ott csökken az elöntések gyakorisága, ami végérvényben csökkenti az ártér feltöltődésének átlagos ütemét (Walling és He 1998). Emellett csökken az ártér vízszállítóképessége is, így a mederre egyre nagyobb terhelés jut, hiszen a vízvezető-képesség romlásával a mederben szállítódik az áradások legnagyobb része (Kozák és Rátky 1999, Nagy et al. 2001).

A folyóhátak morfológiai tulajdonságai (magasságuk és szélességük) függnek az adott folyó hidrológiai tulajdonságaitól (Allen 1965), és nem csak folyóvízi rendszerek között, de ugyanazon vízrendszeren belül is meglehetősen változatos képet mutatnak (Allen 1965, Brierley et al. 1997, Adams et al. 2004). Például Fisk (1947) a Mississippi mentén 4,5-7,5 m magas és legfeljebb 2,5 km széles folyóhátakat vizsgált, Smith (1996) szintén a Mississippin, de annak egy másik szakaszán 3-4 m magas és 2-3 km széles formákat írt le. Ferguson és Brierley (1999) az ausztrál Tuross folyó mentén 3-4 m magas és 50-100 m széles folyóhátakat azonosítottak. A Duna osztrák szakaszán Klasz et al. (2014) legfeljebb 3,7 m magas és 90-300 m széles folyóhátakat mértek, míg Kiss et al. (2018b) a Maros hullámterén 1,1-1,8 m magas és 46-440 m széles formákat írtak le.

A folyóhátak fejlődését számos tényező befolyásolja (Brierley et al. 1997), de hazánkban csak Maros mentén van erre vonatkozó kutatás (Kiss et al. 2018b). Azonban véleményem szerint a folyóhátak formálódását befolyásoló tényezők szerepe kiemelten fontos, hiszen miközben ezek a tényezők módosítják a folyóhátak morfológiai tulajdonságait, ugyanakkor közvetve befolyásolják a folyóhátak víz- és hordalékmennyiség-szabályzó képességét is, és ezáltal pedig befolyásolják az árterek/hullámterek vízvezető-képességét.

Természetes körülmények között a folyóhátak épülését a kanyarulatvándorlás során, a külső íven fellépő erózió szabályozza (Hickin és Nanson 1975, Klasz et al. 2014). A folyóhátak morfológiáját (magasságát és szélességét) befolyásoló tényezők közül a legmeghatározóbb a formák épülésére rendelkezésre álló hely, azaz az ártér szélessége (Brierley et al. 1997, Thonon et al. 2007, Klasz et al. 2014). Ferguson és Brierley (1999) például az ausztrál Tuross folyó hegyvidéki szakaszán vizsgálták, hogy a völgytalp szélességének változása hogyan módosítja a folyóhátak alaktani tulajdonságait. Eredményeik szerint a szük $(200 \mathrm{~m})$ ártéren magas $(5 \mathrm{~m})$ és viszonylag széles (10-20 m) folyóhátak fejlődtek, míg a jóval szélesebb $(1 \mathrm{~km})$ ártéren a formák alacsonyabbak (3-4 m) és keskenyebbek (6-7 m) voltak. Síkvidéki folyók esetében az árterek szélességét azonban jelentősen lecsökkentik az árvízvédelmi töltések, amelyek, ha az aktív mederhez nagyon közel helyezkednek el, jelentősen módosíthatják a folyóháta k magasságát és szélességét is. Ettől függetlenül, a folyóhátak morfometriája hasonló módon alakul, mint a természetes ártereken, hiszen például Klasz et al. (2014) a Duna osztrák szakaszán végzett vizsgálatai szerint a szük hullámtéri szakaszokon $(<1300 \mathrm{~m})$ magasabb (átl. $2 \mathrm{~m})$, míg tág hullámtéren (>1300 m) alacsonyabb (átl. 1,2 m) folyóhátak alakultak ki.

A kanyarulatok kora is hatással lehet a folyóhátak fejlődésére, hiszen meghatározza a part mentén a hordalék-felhalmozódásra rendelkezésre álló időt, így a feltöltődés vastagságát és ütemét. Cazanacli és Smith (1998) kimutatta, hogy fiatalabb mederszakaszok mentén keskenyebb és meredekebb folyóhátak formálódtak, míg idősebb mederszakaszok mentén jóval szélesebb és lankásabb formák alakultak ki. A szerzők ezt a durvább hordalékszemcsék (pl. homok) időben és térben nem egyenletes akkumulációjával magyarázták. Adott mederszakasz kialakulását követően (pl. egy kanyarulat átszakadása vagy átvágása után) a part menti területek még közel vízszintesek, így ezeket az áradások könnyen elöntik. Az ártérre kilépő víz által szállított hordalék a meder menti szük sávban hirtelen lerakódik, ami kezdetben keskeny és meredek folyóhátak kialakulását eredményezi. Ahogy a hordalék felhalmozódása folytatódik az ártéren, a partok egyre magasabbá válnak, így az egyes áradások is nehezebben öntik el a folyóhátakat. A finom szemcséjü lebegtetett hordalék azonban könnyebben szállítódik a teljes ártéren, és a folyóhát medertől távolabbi felén felhalmozódva növelik a formák szélességét és csökkentik azok meredekségét. A folyamat eredményeként a feltöltődés előrehaladtával tehát a folyóhátak szélesebbé és lankásabbá válnak (Cazanacli és Smith 1998). Hazánkban hasonló folyóhát-fejlődést figyelt meg Kiss et al. (2018b) a Maros mentén a 19. századi szabályozásokat követően. 
A kanyarulatok fejlettségéhez szorosan kapcsolódik azok görbületi sugara. Hudson és Heitmuller (2003) fordított arányosságot írt le a kanyarulatok görbületi sugara és a folyóhátak szélessége között, amelyet azzal magyaráztak, hogy a kis görbületi sugár miatt a hordalék nagyobb távolságra is képes eljutni az ártéren, azaz a folyóhátak szélesebbek lesznek. Emellett kapcsolatot állítottak fel a folyó által szállított hordalék szemcsemérete és a folyóhátak szélessége között. Megfigyelték, hogy a szemcseméret csökkenésével csökken a folyóhátak szélessége is. Uddin és Rahman (2012) megfigyelték, hogy a sodorvonal külső ívhez való közelsége miatt a folyóhátak anyaga árvizekkor erodálódhat, amely az átlagmagasságukat és épülésük átlagos ütemét csökkenti.

A folyóhátak fejlődését és morfológiai tulajdonságait befolyásoló eddig bemutatott természetes tényezők hatását jelentős mértékben módosíthatják a különböző antropogén beavatkozások. Például a területhasználat megváltozása (pl. földmüvelés korábbi erdőterületeken, árterek beépítése) jelentősen hozzájárulhatnak a folyóhátak intenzívebb eróziójához, illetve azok hiányához, azonban nem mindegy, hogy a területhasználat-változás a vízgyüjtö-területen, avagy az ártér egy adott szakaszán megy végbe (Wolman és Leopold 1957). Wolman és Leopold (1957) tanulmányukban két, egymáshoz nagyon közel elhelyezkedő kisebb vízfolyást vizsgáltak. Az egyik egy erősen beépített és megmüvelt területen haladt át, így itt az erős antropogén hatások miatt hiányoztak a folyóhátak. A másik vízfolyás esetében a vízgyüjtő-területen változott meg a felszínborítás, ugyanis a vízgyüjtő területet erőteljesen beépítették, így nagyobb lett a felszíni lefolyás és a vízfolyás eróziós képessége. A gyakoribbá váló árvizek és a megnövekedett hordalékmennyiség nagyméretü folyóhátak fejlődését eredményezték a folyó alsóbb szakaszain.

A kanyarulatok külső ívén létesített partbiztositások is befolyásolhatják a folyóhátak fejlödését. Klasz et al. (2014) eredményei szerint a külső ív eróziójának megszünése miatt a partbiztosított szakaszokon fokozódott a hullámtér feltöltődése, amely magasabb folyóhátak kialakulásához vezetett.

Kiss et al. (2018b) a Maros hullámterén vizsgálták a kanyarulat-átvágások, árvízvédelmi töltések, partbiztositások, illetve a mederből történő kavicsbányászat folyóhátak fejlödésére és morfológiai tulajdonságaira gyakorolt hatását. Eredményeik szerint a kanyarulat-átvágások során létrejött új mederszakaszokon - Cazanacli és Smith (1998) eredményeihez hasonlóan keskenyebb és meredekebb folyóhátak fejlődtek. Az árvízvédelmi töltések mederhez való közelsége jelentősen korlátozhatja a folyóhátak szélességét, hiszen azokon a szakaszokon, ahol a hullámtér szük $(<300 \mathrm{~m})$, a folyóhátak elérhetik a töltések lábát. A meder külső ívén épített partbiztosítások hatására 24-36 \%-kal magasabb folyóhátak alakultak ki, mint a szabadon fejlődő kanyarulatok mentén. A kavicsbányászat megindulása miatt a Maros medre az 1950-es évek óta 24\%-kal szükült és 1,2 m-rel bevágódott, amely eredményeként új ártéri szintek alakultak ki, amelyeken újabb folyóhátak kialakulása indult meg, ez pedig a régi formák inaktívvá válását eredményezte. A fiatal folyóhátak nagy magassága miatt azok felszínét már csak a 10 évente visszatérö árvizek képesek elönteni.

A hazai szakirodalmat áttekintve látható, hogy a Maroson végzett kutatáson kívül nem készült olyan elemzés, amely kifejezetten a folyóhátak formálódásával és alaktani jellemzőivel foglakozna. A hullámtér feltöltődésével foglalkozó tanulmányok csak megemlítik a folyóhátakat, mint a hordalék felhalmozódásnak azon kitüntette helyeit, ahol egy-egy árvíz során a legnagyobb mennyiségü hordalék rakódik le (Keller és Marsovszki 1992, Nagy et al. 2001, Szlávik 2001, Kiss et al. 2002, Schweitzer et al. 2002, Balogh et al. 2005, Oroszi et al. 2006ab, Sándor és Kiss 2006ab, 2007). Ráadásul mindössze egy-egy formát vizsgáltak. Ugyanakkor a folyóhátak pontos feltérképezése lényeges eleme a teljes hullámtéri akkumuláció vizsgálatának, hiszen jelentős vízés hordalékmennyiség-szabályzó szerepük révén jelentős hatással vannak a hullámtéren zajló folyamatokra is. Így a folyóhátak méreteinek és fejlödési ütemük ismeretének birtokában a fömeder és a hullámtér vízszállító-képessége is hatékonyabban javítható lenne (Szlávik 2001). 


\subsubsection{Az övzátonyok kialakulása és a fejlödésüket befolyásoló tényezők}

Az övzátonyok a meanderező vízfolyások árterének legjellegzetesebb akkumulációs formái, és a horizontális hordalék-felhalmozódás kiemelt helyszínei (Wolman és Leopold 1957). Ezek a kanyarulatok belső (konvex) ívén formálódó és a parttal párhuzamos, kvázi szabályos gerincek a kanyarulatok görbülete miatt kialakuló másodlagos (helikoidális) áramlások eredményei (Wolman és Leopold 1957, Hooke 1975). A kanyarulat belső ívén a vízáramlás lelassul, amely a hordalék akkumulációját eredményezi (Dietrich és Smith 1983). Anyaguk fenékhordalékból épül fel, de a laterális akkumuláció által felhalmozódott hordalék durvább, mint ami a vertikális akkumuláció során rakódik le (Happ et al. 1940). A kanyarulatok oldalirányú vándorlása következtében újabb övzátony-formák alakulnak ki, amelyek övzátony-sorokat alkotnak (Hickin 1974, Nanson és Hickin 1983). A kanyarulatvándorlás következtében az övzátony-sorokat alkotó idősebb tagok oldalirányú fejlődése idővel megáll, hiszen távolabb kerültek medertől, így megindul rajtuk a vertikális akkumuláció. Árvizek idején így finomabb lebegtetett hordalékkal temetődhetnek be (Happ et al. 1940). Az övzátony-sorok elemzésével általános képet kaphatunk a kanyarulatvándorlás hosszú távú változásáról, azaz az egyes övzátony-tagok morfológiai tulajdonságai jól tükrözik, hogy adott kanyarulat fejlödésében milyen változások következtek be (Hickin 1974, Russel et al. 2018).

Az övzátonyok fejlődését alapvetően a kanyarulatok külső ívén zajló medererózió és a vele együtt járó oldalirányú kanyarulatvándorlás szabályozza (Hickin 1974), így az ezekben bekövetkezett bármilyen változás az övzátonyok formálódását is befolyásolja.

A kanyarulatvándorlás üteme elsősorban az övzátony-sorokat alkotó övzátony-tagok közötti távolságot határozza meg (Hickin és Nanson 1975, Strick et al. 2018). Ha a külső ív elmozdulása gyors ütemben zajlik, akkor a belső ív fejlődése is gyorsabb, így sok egymáshoz közel elhelyezkedő övzátony alakul ki (Hickin és Nanson 1975). Hickin és Nanson (1975) és Nanson és Hickin (1983) a kanyarulatvándorlás mértékét a kanyarulat görbületi sugara és a meder szélességének hányadosával jellemezték. Szerintük a kanyarulatvándorlás üteme akkor éri el a maximumát, amikor az arányszám értéke 3.0, ezen érték felett és alatt pedig hirtelen lelassul. A vándorlás üteme a kanyarulat fejlödésének kezdeti időszakában a nagy görbületi sugár miatt a leglassabb, és ehhez igazodnak az övzátonyok is. Mivel a kanyarulatok vándorlása elsősorban magas vízállások esetén a legintenzívebb (Nanson és Croke 1992, Konrad 2012), így az árvizek magassága és tartóssága is meghatározza a partok elmozdulásának mértékét. Azonban a kanyarulatvándorlás üteme nem egyértelmüen köthető az árvizek szintjéhez, hiszen Nanson és Hickin (1983) ugyanolyan magnitúdójú árvizek során eltérö ütemü kanyarulatvándorlást figyeltek meg, ráadásul eredményeik alapján a külső és a belső ív elmozdulása sem egy időben zajlik. Megfigyeléseik szerint egy gyorsan levonuló, nagy amplitúdójú árvíz a külső ív intenzív erózióját eredményezi, amely hatására a meder jelentősen kiszélesedik. Egy következő, hasonló magnitúdójú árvíz során elhanyagolható mennyiségü erózió lép fel a külső íven, mivel az előző árvíz során a kiszélesedett meder miatt a vízáramlás lelassul, így folytatódik, illetve felgyorsul a belső íven a hordalék akkumulációja (az övzátonyok épülése), amely nagyobb árvizek hiányában addig folytatódik, amíg a meder el nem ér egy egyensúlyi állapotú szélességet, tehát a meder ismét szükebbé válik. Egy újabb árvizet követően pedig a folyamat elölről kezdődik. Tehát a külső ív hátrálását mindig egy kicsit megkésve követi a belső ív épülése, majd a külső ív akkor kezd el újra intenzívebben hátrálni, amikor a belső ív „utoléri”.

A kanyarulatvándorlás típusa az övzátonyok morfológiai tulajdonágait határozhatja meg, de ezzel kapcsolatban csupán néhány kutatás született (Strick et al. 2018). Daniel (1971) a kanyarulatok fejlődésének három alapvető típusát írta le (1. ábra). Az első típus a megnyúló kanyarulatok csoportja, amelyek fejlődése során az inflexiós pontok helyzete nem változik, csupán a kanyarulat középvonal-hosszának növekedése figyelhető meg. Az inflexiós pontok mozdulatlanságának oka, hogy ezeken a pontokon a sürü part menti növényzet vagy a kötöttebb, agyagos mederanyag korlátozza a partok elmozdulását (Daniel 1971). A második típust az elforduló kanyarulatok képviselik, amelyekre jellemző, hogy a kanyarulat tengelyének iránya 
megváltozik, a középvonal hossza megnő, és az egyik inflexiós pont is áthelyeződik. Az elforduló kanyarulatok fejlödése akkor indul meg, amikor a kanyarulaton belül az erózió mértéke nem egyenletes, így a külső ív egyes szakaszai gyorsabb ütemben pusztulnak. Végül az áthelyeződö kanyarulatokra az jellemző, hogy a kanyarulat folyásirányban lefelé elmozdul, anélkül, hogy a középvonal hossza és a kanyarulat tengelyének iránya megváltozna (Daniel 1971). Strick et al. (2018) szerint az övzátonyok morfológiai tulajdonságaira elsősorban az elforduló kanyarulattípus van hatással. Ezek mentén magasabb és szélesebb övzátonyokat figyelt meg, mivel a típusba tartozó kanyarulatok rotációs mozgásuk miatt saját magukra fordulnak vissza, amely a kialakuló övzátonyok magasodását és szélesedését eredményezi.

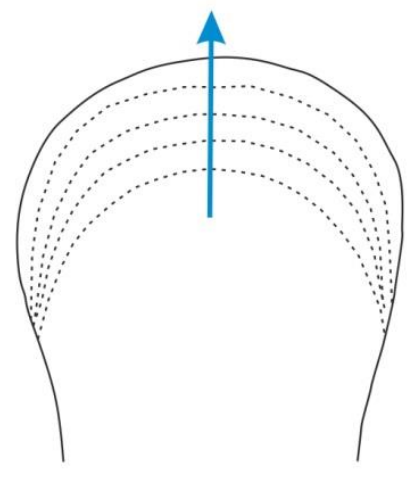

a) Megnyúlás

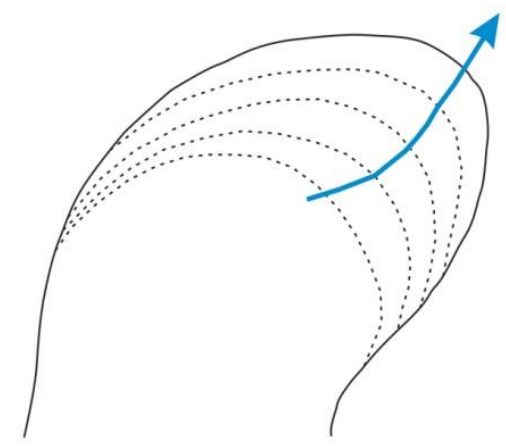

b) Elfordulás

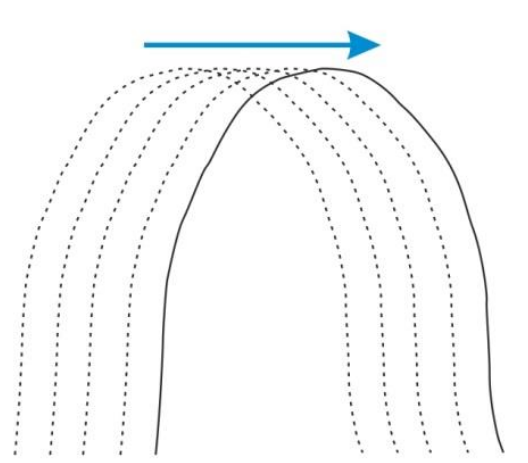

c) Áthelyeződés

1. ábra. Kanyarulatvándorlási típusok Daniel (1971) alapján.

A mederben szállított hordalék mennyisége a kanyarulatvándorlás ütemét, illetve az övzátonyok morfológiai tulajdonságait is befolyásolja. A hordalék származhat egyrészt a vízgyüjtőről (Colby 1963), de rövidebb szakaszokon a kanyarulat külső ívének eróziójából származó hordalék is felhalmozódhat (Happ et al. 1940, Nanson és Hickin 1983). Ha egy kanyarulat külső ívén az intenzív erózió miatt nagy mennyiségü hordalék jut a mederbe, akkor a folyásirányban lefelé elhelyezkedő kanyarulatok belső oldalán intenzívebb hordalékfelhalmozódás figyelhető meg. Ezáltal a kanyarulatok vándorlása is intenzívebbé válik, hiszen a belső ívnek rövidebb idő kell, hogy utolérje a külső ív elmozdulását (Nanson és Hickin 1983). Így a kanyarulatvándorlás üteme ugyanazon folyószakaszon belül kanyarulatonként is igen eltérö lehet.

A meder falát felépítő üledékek kötöttsége befolyásolja a meder erózióval szembeni ellenállását, így hatással van a kanyarulatvándorlás ütemére és irányára, ezáltal a kanyarulatvándorlás típusára is (Daniel 1971, Thorne 1991). A finomabb hordalékból álló üledéktestek, például ártéri mocsarak és paleo-medrek eltemetett üledékei lokálisan lassítják a kanyarulatvándorlás sebességét, mivel a finomabb szemcse-összetételü üledékeknek nagyobb a kötöttsége, így az jobban ellenáll az eróziónak, így csökken a kanyarulatvándorlás üteme, ezáltal a belső íven az övzátonyok fejlődése is (Fisk 1947, Sun et al. 1996, Hudson és Kesel 2000, Hooke 2004, Hernesz 2015). A kanyarulaton belül ezek a kötöttebb szakaszok a kanyarulat külső ívének nem egyenletes erózióját okozzák, így a kanyarulatvándorlás típusa megváltozhat, például egy addig megnyúló kanyarulat elfordulóvá alakul, hiszen a kanyarulat egyes részei a kötött mederanyag miatt lassabban vándorolnak (Daniel 1971).

A vándorlás ütemének lassulását okozhatja, ha a part magassága növekszik a meder bevágódása (Wyżga 2001) vagy az ártér intenzív feltöltődése miatt (Ten Brinke et al. 1998), mivel ugyanolyan ütemü mederelmozdulás fenntartásához a folyónak nagyobb mennyiségü hordalékot kellene egységnyi idő alatt erodálnia (Hickin és Nanson 1975). Thorne (1991) szerint azonban a folyó bevágódásának fokozódása az egyre magasabb külső íven a part stabilitásának csökkenését okozza, így az ott kialakuló és egyre gyakoribbá váló partomlások a kanyarulat vándorlásának gyorsulását eredményezhetik. 
Az aktuális mederszélességet, illetve annak változását tükrözheti az övzátonyok szélessége, hiszen például a meder szükülésével az övzátonyok is egyre keskenyebbé válnak (van de Lageweg et al. 2014, Strick et al. 2018).

A part menti növényzet jelentős hatással van a kanyarulatvándorlás ütemére (Johannesson és Parker 1985, Micheli és Kirchner 2002, Micheli et al. 2004), amely a meder külső ívének eróziójának módosításán keresztül valósul meg (Motta 2014). Ez egyrészt függ a növényzet típusától, hiszen például a lágyszárú növényzet növeli a part erózióval szembeni ellenállását, mivel a part anyagát a gyökérzet stabilizálja (Micheli és Kirchner 2002), ugyanakkor a nagyobb fák bedőlése a partok erózióját időlegesen felgyorsíthatja (Corenblit et al. 2007). A part erodálhatósága függ a növényzet sürüségétől is, például a part menti sürü erdő (Lopez és Garcia 2001), az elhalt fák miatt kialakuló tuskógátak (Daniels és Rhoads 2004), illetve az invazív növényfajok jelenléte (Sándor 2011, Delai et al. 2018) növelik a felszín érdességét, amely a vízáramlás lelassulását eredményezi. Ez az energiáját vesztett víztömeg pedig már nem képes a külső ív eróziójára, ami így az övzátonyok fejlödését is lassíthatja. A kanyarulatok belső ívén, az övzátonyok felszínén megtelepedő növényzet stabilizálja a formák anyagát, így meggátolja, hogy árvizek alkalmával az övzátonyok felszínéről hordalék szállítódjon el, továbbá fokozza a formák felszínén a hordalék felhalmozódását is, tehát elősegítheti az övzátonyok magasodását (Hickin 1984).

A kanyarulatok vándorlását, ezáltal az övzátonyok fejlődését befolyásoló eddig bemutatott természetes tényezők hatását jelentős mértékben felülírhatják az antropogén beavatkozások- a folyókanyarulatok átvágása és a külső íven épült partbiztosítások. A kanyarulatok átvágását követően a megnövekedett esés és munkavégző-képesség miatt intenzívebbé válik a külső ív eróziója (Biedenharn et al. 2000), az átvágott kanyarulat alatt megnő a vízsebesség, így a vízáramlás nagyobb erővel csapódik az alatta elhelyezkedő kanyarulatok külső ívének (Konsoer et al. 2016), amely elsősorban a kanyarulat alsó harmadában érvényesül (Fiala 2002, Sándor 2011). Ezzel párhuzamosan az intenzívebb parterózió miatt a szállított lebegtetett hordalék mennyisége is megnő (Zinger et al. 2011), így a belső ív épülése is intenzívebbé válik (Konsoer et al. 2016). A kanyarulatok átvágása a kanyarulatvándorlás típusát is módosíthatja (Hooke 2004, Zinger et al. 2013), ugyanis a kanyarulatok alsó harmadában jelentkező intenzívebb erózió miatt a kanyarulat mentén a külső ív pusztulása nem egyenletesen zajlik, így például egy addig megnyúló kanyarulat elfordulóvá válhat (Daniel 1971).

A kanyarulatok külső ívén épített partbiztositások elsősorban a hordalék oldalirányú felhalmozódását, azaz az övzátonyok épülését befolyásolják, részben azzal, hogy a külső íven az eróziót lelassítják/megállítják, így csökkentik a mederben a külső ív eróziójából származó hordalékmennyiséget (Kesel 2003). Másrészt a külső ív hátrálásának megállásával, illetve a lecsökkent hordalék-mennyiség miatt bár a belső ív épülése lelassul (Nanson és Hickin 1983), de az övzátony-épülés folytatódhat (Kiss et al. 2018a, 2019b). Kiss et al. (2019b) a 19. század óta az Alsó-Tiszát ért emberi beavatkozások (gátépítés, kanyarulat-átvágások, partbiztosítások kiépítése) hatását vizsgálták. Ezek a beavatkozások megváltoztatták a folyó medermintázatát (kanyarogva feltöltőből kanyarogva bevágódóvá vált), amely hatására az övzátonyok épülése is módosult. Az aktívan épülő övzátonyok száma a felére (47-ről 20-ra), összhosszuk pedig a tizedére (52,3 km-ről 4,7 km-re) csökkent, illetve a meder bevágódása miatt megindult azok eróziója is (Kiss et al. 2018a, 2019b).

A hazai és a nemzetközi szakirodalmat áttekintve megállapítható, hogy az övzátonyok kialakulásának mechanizmusát számos kutatás vizsgálta, és elsősorban a kanyarulatok vándorlása kapcsán kerültek megemlítésre (Hickin 1969, Hickin és Nanson 1975, Jackson 1976, Hooke és Harvey 1983, Hooke 2007). A formák alaktani tulajdonságait (pl. magasság és szélesség) befolyásoló tényezők hatását bár megemlítették, viszont azzal, hogy ezek együttesen milyen hatást gyakorolnak az övzátonyok tulajdonságaira alig vizsgálták (kivéve Strick et al. 2018). Emellett, az is ritkán feltett kutatási kérdés volt, hogy ezek a formák emberi hatásra hogyan módosulnak (kivéve Kiss et al. 2018a, Kiss et al. 2019b). 


\section{Mintaterület}

Az alábbi fejezetben először a Tisza teljes magyarországi szakaszát, majd a részletesen vizsgált Alsó-Tisza-vidéket mutatom be a Csongrád és a szerb országhatár közötti szakaszon, kiemelve ez utóbbi hidrogeográfiai és morfológiai jellemzőit. Szükségesnek tartom a 19. században meginduló folyószabályozások és ármentesítési munkálatokat megelőző természeti viszonyoknak, a munkálatok menetének és következményeinek bemutatását is, hiszen a beavatkozások jelentősen módosították a folyó hidrológiai és morfológiai tulajdonságait, amelyek hatással vannak a hullámtéren zajló - általam vizsgált - geomorfológiai folyamatokra is.

\subsection{A Tisza általános hidrológiai jellemzői}

\subsubsection{A Tisza magyarországi szakaszának általános hidrológiai és morfológiai jellemzői}

A Kárpát-medence keleti felének vizeit a Tisza gyüjti össze és vezeti Titelnél a Dunába (2. ábra). Emiatt igen nagy vízgyüjtő területtel rendelkezik (157 ezer km²; Pécsi 1969), amelynek 58\%-a hegy-és dombvidék, míg a maradék 42\% kis esésủ síkvidéki terület (Szlávik 2000). Hossza $964 \mathrm{~km}$ (Somogyi 2000), amelyböl Magyarország területére $587 \mathrm{~km}$ esik (Vágás és Bezdán 2015). A Tisza Ukrajna területén, a Máramarosi-havasokban ered, és két fö forráságának a Rahónál (Rahov) egyesülö Fekete- és Fehér-Tisza tekinthető (Lászlóffy 1982). A vízgyüjtőt északon, keleten és délen a Kárpátok vonulata, nyugaton pedig a Duna-Tisza közi homokhátság határolja (Szlávik 2000). Hazánk területének mintegy fele a Tisza vízgyüjtőjéhez tartozik, így az idők során társadalmi és gazdasági szempontból is kiemelkedő szerephez jutott és fontosságúvá vált (Lászlóffy 1982).
1. Rahó
6. Tiszaug
2. Tiszabecs
7. Csongrád
3. Vásárosnamény
4. Tokaj
8. Szeged
5. Szolnok
9. Titel

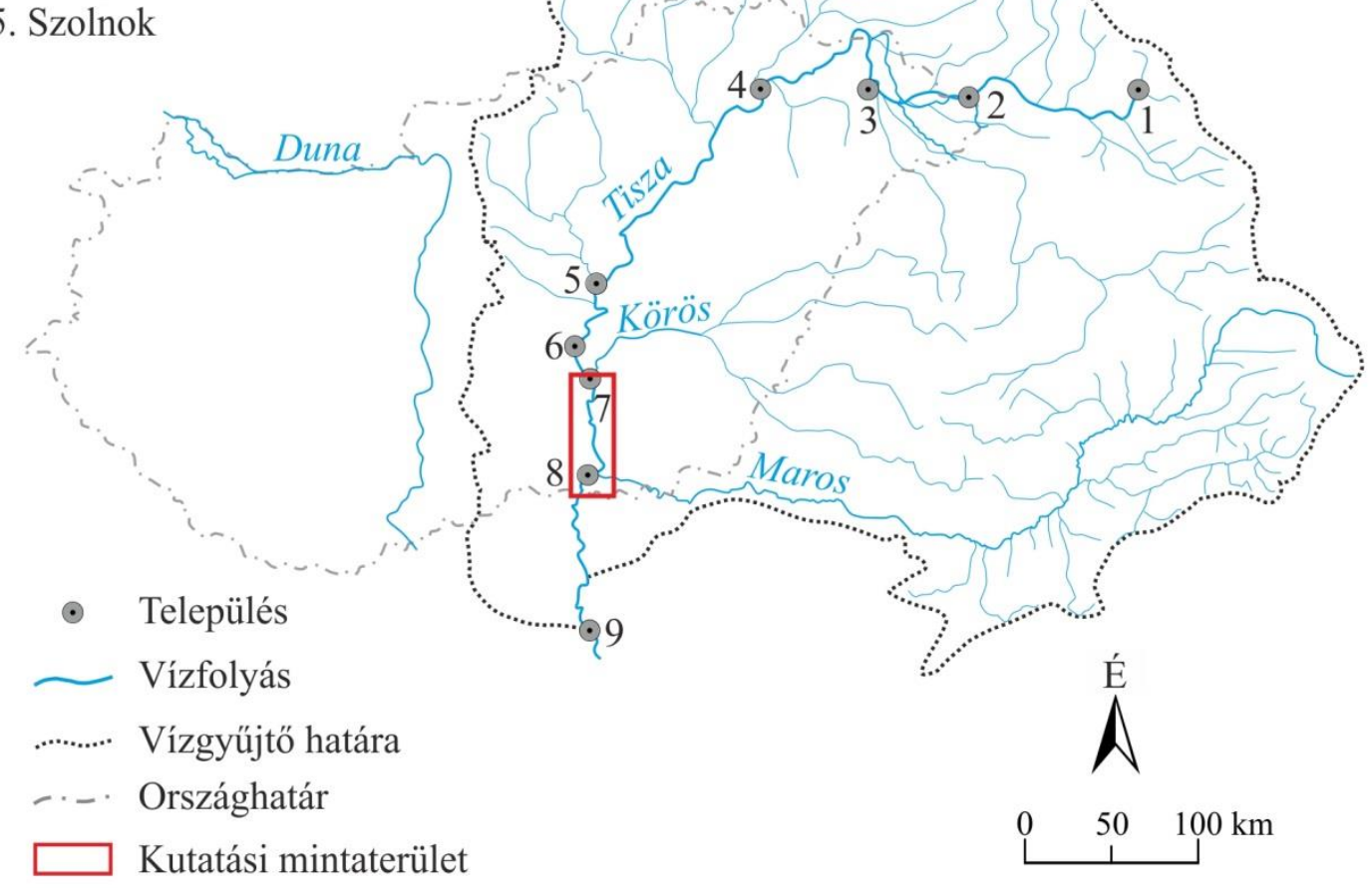

2. ábra. A Tisza vízgyüjtö területe és a vizsgált szakasz elhelyezkedése 
A Tisza vízjárása elsősorban a hegy-és dombvidéken hulló csapadéktól, illetve a tavaszi hóolvadás intenzitásától függ (Bogdánfy 1901, Pécsi 1969, Vágás 1982, Szlávik 2000, Andó 2002). A vízgyüjtő tulajdonságai alapján a folyóra a szélsőségesbe hajló vízjárás jellemző (Pécsi 1969). Ennek oka egyrészt az, hogy a Tisza és mellékfolyóinak forrásvidéke nagyrészt a Kárpátokhoz és az Erdélyi-középhegységhez tartozó 1000-2500 m tengerszint feletti magasságú hegyvidéki területekre esik, ahol az éves csapadékmennyiség meglehetősen sok (1000-1400 mm), amelynek éven belüli eloszlása azonban nem egyenletes (Ihrig 1973, Andó 2002). Másrészt a vízgyüjtőt alkotó kőzetek nagy része impermeábilis agyagos üledék vagy félig vízáteresztő márgás, palás homokkő, amelyek nagyobb felszíni lefolyást eredményeznek (Bogdánfy 1901, Lászlóffy 1982, Szlávik 2000). A nagyobb reliefü területeken a felszíni lefolyást nagyban befolyásolhatja a növénytakaró is, amely csökkenti a lefolyó víz és a folyóba bekerülő hordalék mennyiségét (Lászlóffy 1982). A nagyobb mennyiségű csapadék, a felszín nagy esése és a kőzetek kis vízáteresztő képessége együttesen hevesebb vízjárás kialakulását eredményezik a hegy-és dombvidéki területeken. Az itt eredő mellékfolyók gyors árhullámai ezért nagymértékben befolyásolhatják a Tisza árvizeinek magasságát, elsősorban a Felső-Tisza mentén (Pécsi 1969, Andó 2002).

A magyarországi Tisza-szakasz árvizes időszakai jellemzően kora tavaszra és kora nyárra esnek. Tavasszal a hegy-és dombvidéken meginduló hóolvadás és az ezzel egy időben lehulló csapadék miatt alakul ki az első árhullám, míg a kora nyári időszakban a nagy mennyiségű eső miatt jellemző az ún. zöldár (Bogdánfy 1901, Lászlóffy 1982, Vágás 1982). A kettő közül rendszerint a tavaszi jóval magasabb és tartósabb, ami elsősorban az egymásra torlódó hóolvadások okozta árhullámoknak köszönhető. Az árvizek során általánosan megfigyelt jelenség, hogy az árhullám áradó ágában a vízhozam a vízállás tetőzését megelőzően éri el maximumát, amelyet az árvízi hurokgörbék is jól mutatnak (Vágás és Bezdán 2015). Az áradó ágban a meder intenzív eróziója figyelhető meg, amikor is a meder mélysége 1-2 m-rel is növekedhet, majd az apadó ágban a meder feltöltődése jellemző (Károlyi 1960). A felszálló ágban jelentkező medermélyülés és szelvényterület-növekedés a folyó nagyobb munkavégző-képességével hozható kapcsolatba (Fiala et al. 2007).

Az árvizek levonulásának hossza eltérő a folyó felső és az alsóbb szakaszain. A FelsőTisza-vidéken az áradások 5-20 napig (Rakonczai és Kozák 2009), míg az Alsó-Tisza mentén 1-3 hónapig is eltarthatnak (Kiss 2014). Ennek oka, hogy a vízgyüjtő felső szakaszán, a viszonylag nagyobb esés miatt az áradások gyorsabban levonulnak. Azonban a középső és alsó szakaszokon egyrészt a jóval kisebb esés, másrészt a Körösök és a Maros egyidejü áradásai, és a Dunával együtt kifejtett visszaduzzasztó hatásuk miatt (amely akár Szolnokig is érvényesülhet) a víz nem tud olyan gyorsan levezetődni, így az áradások összetorlódhatnak és jóval hosszabb ideig tartó magas vízállások is kialakulhatnak (Bogdánfy 1901, Szlávik 2000). Ebből adódóan az egyes vízmércéken mért legmagasabb vízállások (LNV) éve eltér a folyó felső, középső és alsó szakaszán (2. táblázat), mindössze két olyan árvizes év volt (1888 és 1970) amikor a Tisza teljes magyarországi szakaszán megdőltek az addigi árvízi rekordok. A Tisza vízhozamai is eltérő értékeket mutatnak, az Alsó-Tiszán a folyó legnagyobb vízhozama $\left(4346 \mathrm{~m}^{3} / \mathrm{s}\right)$ közel 1,5-szerese a Felső-Tiszán mért maximális árvízi vízhozamnak $\left(3270 \mathrm{~m}^{3} / \mathrm{s}\right.$, Lászlóffy 1982).

Az őszi hónapokban is jelentkezhetnek árhullámok, de ez leginkább csak a Felső-Tiszavidéken jellemző, ahol ősszel jóval több csapadék esik, mint az alsóbb szakaszokon (Vágás 1982). Kivételesnek számított az 1998. évi őszi árvíz, amely a Felső-Tiszán rekordmagasságot ért el, ugyanis Tivadarnál $958 \mathrm{~cm}$-rel tetőzött, ami $46 \mathrm{~cm}$-rel volt magasabb, mint az 1970-es árvíz tetőző vízszintje (Vágás 2003). 
2. táblázat. A Felsö-, Közép-, és Alsó-Tiszán mért rekord (LNV) vízállások a 19. század vége óta (forrás: Lászlóffy 1982, Lóczy et al. 2009, Kiss 2014, http://www.hydroinfo.hu).

\begin{tabular}{|l|c|c|c|c|c|c|c|c|c|c|c|c|c|c|}
\hline Vízmérce & \multicolumn{10}{|c|}{ Éves legmagasabb vízállás $(\mathrm{cm})$} \\
\hline & 1876 & 1879 & 1881 & 1888 & 1895 & 1919 & 1932 & 1944 & 1970 & 1998 & 1999 & 2000 & 2001 & 2006 \\
\hline Vásárosnamény & 817 & - & 869 & 900 & - & - & - & - & 912 & 923 & - & - & 943 & - \\
\hline Szolnok & - & - & - & 818 & - & 884 & 894 & - & 909 & - & 974 & 1041 & - & - \\
\hline Szeged & 786 & 806 & 845 & 847 & 884 & 916 & 923 & 954 & 960 & - & - & - & & 1009 \\
\hline
\end{tabular}

A szélsőséges vízjárás másik véglete a száraz időszakokban fellépő vízhiány, amely kisvizek kialakulásához vezet, ami összefüggésben van az impermeábilis kőzetek jelenléte miatti vízkészlet-csökkenéssel. Kisvizes időszakok akkor alakulnak ki, ha a vízgyüjtő területek felől megszünik a felszíni vízutánpótlás. A Tiszán kisvizes időszakok késő nyáron és kora összel jellemzők. Ezen kívül a téli hónapokban is előfordulhatnak igen alacsony vízállások, főleg akkor, ha az elöző évi ősszel kevés csapadék esett, a tél pedig hideg (Lászlóffy 1982). Az eddig mért legkisebb vízállások (LKV) Vásárosnaménynál $-235 \mathrm{~cm}$ (2003-ban), Szolnoknál -279 cm (2003-ban) és Szegednél -250 cm (1946-ban) ${ }^{1}$. A közepes kisvízi vízhozamok alakulása szintén szakaszonként eltérő, Vásárosnaménynál $29 \mathrm{~m}^{3} / \mathrm{s}$, Szolnoknál $65 \mathrm{~m}^{3} / \mathrm{s}$, Szegednél pedig $160 \mathrm{~m}^{3} / \mathrm{s}$ (Lászlóffy 1982). A szélsőséges vízjárást jól bizonyítja, hogy Vásárosnaménynál az eddig mért legalacsonyabb és legmagasabb vízállások különbsége közel 8 méter is lehet, de a Tisza alsó szakaszán Csongrádnál a 13 m-t is meghaladja ${ }^{1}$.

A Magyarország területére eső Tisza szakasz eltérő természetföldrajzi tulajdonságokkal rendelkezik, így a folyó jellemzésének megkönnyítése végett három különálló egységre osztották, amely azonban nem illeszkedik a teljes Tisza felosztásához. A Felső-Tisza-vidék Tiszabecstől a Bodrog torkolatáig (Tokaj) tart, a Közép-Tisza-vidék Tokajtól Tiszaugig húzódik, míg az Alsó-Tisza-vidék a Tiszaug és a szerb határ közötti folyószakaszt és környezetét foglalja magába (Ihrig 1973).

A Felsö-Tisza esése a forrásvidékén jellemző 20-50 m/km-es érték Magyarországra érve fokozatosan csökken, de még mindig itt a legnagyobb a hazai szakaszon, hiszen Vásárosnaményig esése átlagosan $13 \mathrm{~cm} / \mathrm{km}$, ami Tokajig $8,8 \mathrm{~cm} / \mathrm{km}$-re csökken. Ez a hordalékszállítás és a medermintázat megváltozását is eredményezi, hiszen a határon túli szakaszon Tiszabecsig a szállított fenékhordalék nagyrészt durva kavics, medre pedig több ágra szakad, mivel a mederben lerakódó kavicsos-homokos hordalék nagy zátonyokat és szigeteket alkot (Ihrig 1973, Lászlóffy 1982, Kiss és Hajdu 2015). Az országhatártól a folyó egyágú, meanderező mederben folyik. Mivel az esés fokozatosan csökken, a hordalék szemcsemérete is megváltozik: Vásárosnaményig a fenékhordalék mérete az apró kavicstól a finom homok mérettartományába csökken (Ihrig 1973). A Felső-Tisza mentén a mellékfolyók közül csupán a Szamos rendelkezik nagyobb eséssel, mint a Tisza, mivel a Szamos egészen a vásárosnaményi torkolatig nagyesésű hordalékkúpján folyik, így a torkolatig szállít kavicsos hordalékot (Bogárdi 1971). A kavicsos fenékhordalék jelenléte ellenére a Felső-Tiszán is a lebegtetett hordalék van jelen a legnagyobb mennyiségben, hiszen ezen a szakaszon a Tisza már ezerszer annyi lebegtetett hordalékot szállít $\left(5,4\right.$ millió $\left.\mathrm{m}^{3} / \mathrm{év}\right)$, mint görgetettet $(3900$ $\mathrm{m}^{3}$ /év; Bogárdi 1971). A még viszonylag nagy esés és a felszínt alkotó laza üledékek lehetővé teszik a kanyarulatok gyors vándorlását azokon a szakaszokon, ahol nincs partbiztosítás (Károlyi 1960, Mike 1991). A meder átlagos szélessége $200 \mathrm{~m}$ körüli, azonban például Zemplénagárd térségében 420 m-re is szélesedhet (Lászlóffy 1982).

A Közép-Tisza mentén Tokajtól kezdve az esés egyre csökken, a Kisköre környéki szakaszon 3,5 cm/km, Szolnoktól pedig már csak1-2,5 cm/km (Lászlóffy 1982). A hordalék és a mederanyag csaknem teljes egészében a finom iszap és agyag szemcseméret tartományba esik, amely a kis esésű felszínt a kanyarulatképződéssel szemben ellenállóbbá teszi. Így - a

\footnotetext{
${ }^{1}$ http://www.hydroinfo.hu/Html/hidelo/hidelo_graf_tisza.html
} 
később bemutatásra kerülő szabályozási munkák mellett - ezért is találunk kevesebb számú, lassabban fejlődő, de nagyobb ívü kanyarulatokat (Lászlóffy 1982). A szabályozási munkálatok előtt a Tiszaújvárosnál a Tiszába torkolló Sajó jelentős mennyiségü durva hordalékot szállított a Tiszába és a torkolatban nagyméretü hordalékdugók létrejöttét eredményezte, így egy rövid szakaszon a Tisza medrének esése mindössze 1-1,5 cm/ $\mathrm{km}$ volt (Botár és Károlyi 1971, Vágás 1982). A középmeder szélessége itt is átlagosan 200 m, viszont vannak olyan szakaszok, ahol a 100 m-t sem éri el (Szolnoknál csupán 95 m), míg máshol a 300 m-i elérheti (Lászlóffy 1982).

\subsubsection{Az Alsó-Tisza és árterének morfológiai és hidrológiai jellemzői}

Kutatásomat az Alsó-Tisza Csongrád és szerb országhatár közötti 92 km hosszú szakaszát (257-165 fkm) kísérő hullámtéren végeztem (3. ábra). Természetföldrajzi szempontból az Alsó-Tiszavidék középtájhoz tartozik, és a folyó hullámtere mellett ide tartoznak a szabályozások előtti ártéri területek is. A tájat nyugatról a Kiskunsági-löszöshát és a Dorozsma-Majsai-homokhát, keletről pedig a Csongrádi-sík határolja (Marosi és Somogyi 1990).

Az Alsó-Tiszán a legjelentősebb áradások tavasszal jelentkeznek, amikor a felsőbb szakaszon meginduló hóolvadás következtében kialakuló árhullámok a Tisza alsó szakaszán rendszerint összetorlódnak, így kialakítva több hónapig eltartó áradásokat. A március-április környékén jelentkező áradások akár júniusig is eltarthatnak (Rakonczai és Kozák 2009). Az Alsó-Tisza vízjárását elsősorban a mellékfolyók, a Csongrádnál beömlö Hármas-Körös, illetve a Szegednél betorkolló Maros befolyásolják, de kiemelkedő hatása lehet a Duna visszaduzzasztásának is (Bogdánfy 1901, Rakonczai és Kozák 2009, Vágás és Bezdán 2015). A Hármas-Körös közepes vízhozama Kunszentmártonnál $105 \mathrm{~m}^{3} / \mathrm{s}$, míg árvízkor $1150 \mathrm{~m}^{3} / \mathrm{s}$ maximális vízhozammal növelheti a Tisza vízhozamát. Ha árvize egybeesik a Tiszáéval, duzzasztó hatása miatt Szegeden az árvíz hamarabb tetőzhet, mint Szolnokon. Ez történt például az 1895, 1919, 1924, 1932 és 2006. évi árvizek esetében (Lászlóffy 1982). A Maros közepes vízhozama Makónál $160 \mathrm{~m}^{3} / \mathrm{s}$, míg árvízkor a Tisza vízhozamát max. $1800 \mathrm{~m}^{3} / \mathrm{s}$ árvízi vízhozammal növeli, és tavaszi árvizei rendszerint összefutnak a Tiszáéval (Lászlóffy 1982). A 2006. évi árvíz bekövetkeztéig a szakemberek kételkedtek a Duna jelentős visszaduzzasztó hatásában (Rakonczai és Kozák 2009), de az árvíz megdöntött minden akkori rekordot, Szegednél $1009 \mathrm{~cm}-\mathrm{t}$, Mindszentnél 1062, Csongrádnál pedig $1033 \mathrm{~cm}$-t mértek, miközben vízhozama korántsem volt a legnagyobb (2006: $3780 \mathrm{~m}^{3} / \mathrm{s}$, míg 1932: $\left.4346 \mathrm{~m}^{3} / \mathrm{s}\right)$. Ekkor a Duna duzzasztó hatása egészen Szolnokig érződött (Vágás és Bezdán 2015).

A folyó átlagos kisvízi hozama Szegednél $160 \mathrm{~m}^{3} / \mathrm{s}$, közepes vízhozama $810 \mathrm{~m}^{3} / \mathrm{s}$, legnagyobb árvízi hozama pedig $4346 \mathrm{~m}^{3} / \mathrm{s}$ (Lászlóffy 1982, Kiss 2014). Az árvizek magassága a szabályzások óta 11-szer dőlt meg az Alsó-Tiszán (2. táblázat), és hosszuk is jelentősen változott (Sándor 2011, Kiss 2014). A 20. század elején a szabályozásokat követően a meder esésének növekedése miatt az árvizek levonulása felgyorsult, így évente 30 árvizes nap volt jellemzö. Az 1910 és 1940 közötti időszakban a meder szükülésnek indult, az árvizek szintje magasabbá vált, ami az árvizes napok hosszát megduplázta (61 nap/év). Az 1990-es évekig csökkent az árvizek hossza, és csupán néhány nagyobb árvíz vonult végig az Alsó-Tiszán (1970-ben és 1974-ben). A század legvégén és a 2000-es években az árvizek hossza 51 nap/év-re csökkent, illetve 2000-ben és 2006-ban is megdőlt az addig mért legnagyobb vízállás (Kiss et al. 2019a).

A kisvizek szintje is megváltozott, ugyanis a 20. század elején, a szabályozásokat követően a vízszint esésének növekedése következtében megnőtt munkavégző képesség a meder bevágódását eredményezte. Például az Alsó-Tisza középső szakaszán (Mindszentnél) 1890 és 1929 között a meder 2,4 m-rel mélyült, a kisvizek szintje pedig $131 \mathrm{~cm}$-t süllyedt (Kiss 2014). A század közepéig a kisvizek szintjében nem következett be jelentősebb változás. Az 1940 és 1990 közötti időszakban azonban számos LKV rekord is megdőlt (pl. 
Szegeden 1946-ban -250 cm-t mértek, Csongrádon 1950-ben pedig $-344 \mathrm{~cm}$ volt), emellett a kisvízi hozamok is nőttek, amely a meder bevágódását jelzi (Kiss et al. 2019a). Ennek intenzív folyamatát mutatja, hogy Mindszentnél a meder közepes mélysége 3,2 m-rel nőtt (Kiss 2014). Az 1976-ban üzembe helyezett törökbecsei duzzasztómü célja azonban az Alsó-Tisza kisvizeinek szabályozása, amelynek hatására a kisvizek szintje ma már nem igen csökken a vízmércék '0' pontja alá (Rakonczai és Kozák 2009). Az árvizek szintjének emelkedése és a kisvízszintek csökkenése a vízjárás egyre szélsőségesebbé válását eredményezte. Ennek mértéke az Alsó-Tisza mentén a legnagyobb, az LNV és LKV közötti különbség Csongrádnál 13,9 m, Mindszentnél 13,6 m, Algyőnél 13 m, Szegednél pedig 12,6 m¹.

A vízáramlás sebessége a mederben legfeljebb 1,1 m/s (Kiss 2014). Ehhez képest a hullámtéren az átlagos vízsebesség jóval kisebb (Sándor 2011). A mederrel párhuzamos erdei utak és tiszta sorközü ültetett erdőkben, illetve a gátak lábánál a vízáramlás felgyorsulhat (max. $0,6 \mathrm{~m} / \mathrm{s})$, míg közvetlenül a partélnél a vízáramlás sebessége akár $0,68 \mathrm{~m} / \mathrm{s}$ is lehet (Sándor 2011). Sándor (2011) a 2006. évi árvíz során végzett mérései alapján megállapította, hogy a vízáramlás sebessége nem a parttól való távolsággal mutat kapcsolatot, hanem azt a felszínborítás típusa határozza meg. Szántóterületek és igen sürü növényzettel rendelkező foltok határán például $0,46 \mathrm{~m} / \mathrm{s}$-ot mért, míg igen sürü gyalogakácosban $0 \mathrm{~m} / \mathrm{s}-\mathrm{ra}$ is lecsökkenhet a vízsebesség. Kiss et al. (2019c) modellezés segítségével kimutatták, hogy a gyalogakác kiirtásával a hullámtéren a vízáramlás sebessége közel háromszorosára lenne növelhető $(0,3 \mathrm{~m} / \mathrm{s}-\mathrm{ra})$.

Morfológiáját tekintve az Alsó-Tisza különbözik a Felső- és a Közép-Tiszától. A vízszint átlagos esése kicsi, mindössze 1-1,5 $\mathrm{cm} / \mathrm{km}$ (Kiss 2014), azonban a Maros torkolata alatt $5 \mathrm{~cm} / \mathrm{km}$-re nő (Lászlóffy 1982). Az esés a 20. század eleje óta azonban romló tendenciát mutat (Kiss et al. 2019a): míg 1900 és 1950 között az időszak 50\%ában nagyobb volt, mint $2 \mathrm{~cm} / \mathrm{km}$, a kisvizek esése pedig 1-1,5 cm/km volt, addig az 1980as évektől az esés jelentősen lecsökkent,

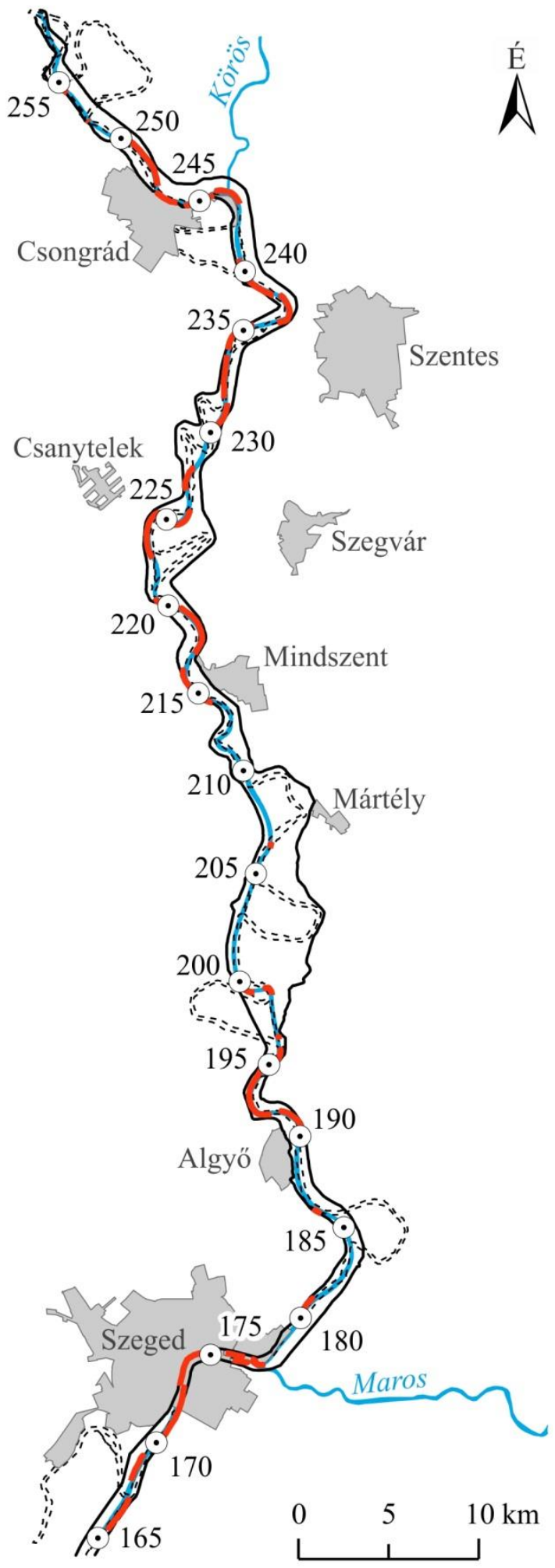

- Folyamkilométer

〜 Partbiztosítás

— Árvízvédelmi töltés

-...-. Tisza szabályozások előtti futása

- Tisza jelenlegi futása

3. ábra. A kutatás mintaterülete az Alsó-

Tisza Csongrád és szerb országhatár közötti hullámtere 
hiszen az időszak 50\%-ában már csak 1,4-1,5 cm/ $\mathrm{km}$ volt a vízszint esése, a kisvizeké pedig gyakorlatilag $0 \mathrm{~cm} / \mathrm{km}$-re csökkent a törökbecsei duzzasztómü hatása miatt (Kiss 2014).

Az Alsó-Tisza szakaszán a folyó nagy mennyiségü finomszemü (homokos és iszapos) hordalékot szállít, amelynek éves mennyisége Szegednél 12,3 millió $\mathrm{m}^{3}$, a görgetett hordalék mennyisége pedig elhanyagolható (19000 m³/év; Bogárdi 1971). A lebegtetve szállított hordalék koncentrációja átlagosan $370 \mathrm{~g} / \mathrm{m}^{3}$ (Kiss 2014). Árvízkor ez legfeljebb $2000 \mathrm{~g} / \mathrm{m}^{3}$ (Kiss 2014), amely azonban évszakonként, illetve az árvizek felszálló és leszálló ágában is igen eltérö. A folyó a legtöbb lebegtetett hordalékot a tavaszi és a kora nyári árvizekkor szállítja, hiszen a vízgyüjtő területről növénytakaró hiányában több anyag mosódhat a mederbe (Sándor 2011). Egy árvíz során a hordalék koncentrációja az áradó ágban, a tetőzés elött 1-2 nappal a legnagyobb, majd a tetőzést követően hirtelen lecsökken (Csépes et al. 2003). Nem csak a vízgyüjtőről, de parterózió révén is juthat anyag a mederbe. A szabályozásokat követően a folyó megnövekedett energiáját a vezérárkok kiszélesítésére fordította, illetve tovább folytatódott a kanyarulatok fejlödése is, és a fellépő intenzív parterózió a lebegtetett hordalékhozam megnövekedését eredményezte (Károlyi 1960). Az 1930-as évektől a partbiztosítások kiépítését követően a partelmozdulás sebessége lelassult, így lecsökkenhetett a parterózióból származó hordalék mennyisége is. A meder folyamatos mélyülése következtében a folyóparton csuszamlásos folyamatok indultak meg, illetve a kiépített partbiztosításokat a folyó folyamatosan megbontja (Kiss et al. 2019b), amely következtében ismét nagyobb mennyiségü anyag kerülhet a mederbe. A parterózióból származó hordaléktöbblet azonban nem csak időben, de térben is változhat, hiszen egy adott szakaszon, a hullámtéren felhalmozódik a felsőbb szakaszokon termelödött hordaléktöbblet, majd a hordalékától megszabadult víz intenzívebb parterózió révén újra hordaléktöbbletet termel, amelyet az alsóbb szakaszokon ismételten lerak (Sándor 2011). A Tisza által szállított hordalék mennyiségét a beömlő mellékfolyók is befolyásolhatják. A Hármas-Körös esése a Tiszáéhoz hasonló $(0,5-3,3 \mathrm{~cm} / \mathrm{km})$, így a torkolati szakaszon kevésbé hat a befogadójára. Ráadásul mindössze 0,4 millió $\mathrm{m}^{3} /$ év lebegtetett hordalékmennyiséggel járul hozzá a Tisza hordalékszállításához (Bogárdi 1971). Ez összefüggésbe hozható azzal, hogy a HármasKörösön két duzzasztó is található, az 1907-ben megnyitott Bökényi-duzzasztó (5,5fkm), illetve az az 1942-ben üzembe helyezett Békésszentandrási-duzzasztó (48,0fkm; Dóka 1997). A Maros esése fokozatosan csökken a torkolat felé, hiszen míg a hordalékkúpi szakaszán (Makó és Apátfalva között) az ártéresés $30 \mathrm{~cm} / \mathrm{km}$, a hordalékkúp elöterében $5 \mathrm{~cm} / \mathrm{km}$, míg a torkolatnál mindössze $2 \mathrm{~cm} / \mathrm{km}$ (Kiss 2014). A folyó nagy mennyiségü lebegtetett hordalékot (4,3 millió $\mathrm{m}^{3} / \mathrm{e} v$ ) és durvább szemcséjü homokot is szállít a Tiszába (Bogárdi 1971), jelentősen megváltoztatva a Tisza hordalékháztartását. A Maros vízrendszerét erős antropogén hatások érték a 20. század során (duzzasztók, mederből történő kavicsbányászat), amely miatt az árvizek hossza jelentősen lerövidült (6-21 nap/év), illetve az utóbbi évtizedekben el is tüntek (Kiss 2014), ami hat a Tisza vízjárására is.

Az Alsó-Tisza mentén a meder anyaga kötött, finom iszap és agyag alkotja, ami megakadályozza a kanyarulatok intenzív vándorlását, így a szabályozási munkálatok előtt kevés, de nagyméretủ íves kanyarulat jellemezte a folyót (Lászlóffy 1982). A meder jelenlegi átlagos szélessége a vizsgált szakaszon $160 \mathrm{~m}$, azonban Mindszentnél a legszükebb, mindössze $90 \mathrm{~m}$. A Tisza átlagos mélysége napjainkban $14 \mathrm{~m}$, de árvizek alkalmával a 19-22 m-t is elérheti (Lászlóffy 1982, Kiss et al. 2019a).

Az Alsó-Tisza menti hullámtér jelenleg 1-4 km szélességben követi a folyót, amelynek nagy részét ártéri erdők és telepített nyárerdők borítják (Sándor és Kiss 2006b). Az 1950-es évektől intenzív erdőtelepítés zajlott, amely a réteken és a legelőkön vált általános gyakorlattá (Oroszi 2009). Emellett intenzív terjedésnek indultak a különböző özönnövények is. Mindezek eredményeképpen a hullámtér növényzeti érdessége a négyszeresére növekedett a szabályozások előtt állapotokhoz képest (néhány pontszerü adat alapján), ráadásul az ártéri és ültetett erdők 74\%-a gyalogakáccal fertőzött (Sándor 2011). 
Az Alsó-Tisza aktív ártérén kívül húzódik az egykor elöntött ártéri területek sávja. Mivel ez a terület volt a viszonyítási felszín a feltöltődés vizsgálatakor, ezért fontosnak tartom rövid bemutatását, hiszen a mentett oldal tulajdonságai befolyásolhatják a mért adatokat. A mentett oldali ártér alacsony fekvésü terület $(77,91 \mathrm{mBf})$, de morfológiáját tekintve nem egységes. Az Alsó-Tisza mentén három ártéri szint különíthető el (Hernesz 2015). A mai medret 2,5-7 km szélességben követi az az ártéri szint (A-szint), amelyet a szabályozások előtt elöntöttek az árvizek. Ennek folytonosságát a térszínből kiemelkedő magasabb ártéri szigetek szakítják meg. Ez a szint viszonylag markáns peremmel különül el a magasabb ártéri szintektöl. Az A-szint fölé 3-5 méterrel magasodik egy köztes (B) ártéri szint, amely a mintaterületen csupán Csongrád, Hódmezővásárhely és Szeged környékén maradt fenn mozaikos formában. A legidősebb, és egyben legmagasabb ártéri szint (C-szint) Hódmezővásárhelytől északra a folyó bal oldalán keskeny sávban maradt fenn (Hernesz 2015). A XIX. század közepén meginduló folyószabályozási és ármentesítési munkálatok elött a Tisza menti területek meglehetősen más képet mutattak, mint manapság. Az év nagy részében vízborítás alatt álltak nemcsak a folyó menti, hanem a távolabbi területek is. A Csongrád és Szeged közötti, 8-10 km széles A-szintet a folyó rendszeresen elárasztotta. Jóval vizenyősebb lehetett a mélyebb fekvésü, Szeged, Hódmezővásárhely és Makó közötti területen lévő Tisza-Maros szög, amely a két folyó közös ártere volt, és az év szinte teljes egészében elöntés alatt állt (Ihrig 1973).

\subsection{Az ármentesítési és szabályozási munkálatok és következményei}

\subsubsection{A 19-21. századi meder- és ártér-szabályozási munkálatok a Tisza magyarországi szakaszán}

Az átfogó folyószabályozások elött az Alföld ártéri területei az év egy részében vagy teljes egészében vízborítás alatt álltak, amely szinte lehetetlenné tette az infrastruktúra fejlödését, illetve a kor követelményeit kielégítő mezőgazdaság tevékenység térnyerését az aktív ártéren. Az egykori ártér kiterjedését az I. Katonai Felmérés (1763-1787) térképei jól mutatják, de fenntartásokkal kell kezelni, hiszen az elöntött területek kiterjedése függött az adott időszak csapadék- és árvízi viszonyaitól (Ihrig 1973). Az ártéri területek kiterjedéséről a Lányi Sámuel vezette térképezés ad pontosabb információt, amely szerint megközelítőleg 20 ezer km² volt az elöntött területek kiterjedése a Tisza vízrendszere mentén, amelyböl közel $5000 \mathrm{~km}^{2}$-nyi az év teljes egészében vízborítás alatt állt (Botár és Károlyi 1971, Dunka et al. 1996).

A XIX. században meginduló Tisza-szabályozás előtt is jelentős emberi beavatkozások történtek a folyók és árterületeik életébe. A lokális munkák az árvizek elleni védekezést célozták (pl. árvízelvezető-árkok létesítése, töltések építése), de ezek rendszerint kudarcba fulladtak, illetve csupán csak egy-egy rövidebb szakaszt érintettek (Ihrig 1973), míg nemkívánt következményeik nagyobb területre is hathattak (Dunka et al. 1996). Az 1800-as évek közepéig a legnagyobb mértékü emberi beavatkozást a vízimalmok jelentették, amelyek hátráltatták a szabályozások megkezdését (Botár és Károlyi 1971). Míg a kisebb mellékfolyókat a vízimalmok müködtetéséhez elgátolták és malomcsatornákat alakítottak ki, addig magán a Tiszán (elgátolás nélkül) kb. 10000 vízimalom müködött (Ihrig 1973). Száraz időszakokban rendszeres volt, hogy a vízhiányos idöszak késleltetése végett a malomgátakat megmagasították, hogy minél több vizet lehessen tárolni, így a malmok tovább tudtak müködni. A létrehozott malomgátak azonban a medrek feliszapolódását, az árterek elmocsarasodását okozták (Lászlóffy 1982), így a szabályozások kezdete elött nélkülözhetetlen volt ezek felszámolása (Ihrig 1973).

A Tisza szabályozásának gondolata már a XVII. században is felmerült, azonban tényleges, az egész vízrendszert érintő átfogó beavatkozásra csak az 1800-as évek közepén került sor, amikor a gazdasági és társadalmi érdekek miatt egyre sürgetőbbé vált a szabályozás gyakorlati megvalósítása. A török kor utáni gazdasági stabilizálódás eredményeként megindult a népesség növekedése, amely magával vonta a mezőgazdasági müvelés alá vont területek növekedésének 
igényét, a városok bővülését, az ipari fejlődést, illetve a közlekedési infrastruktúra kibővülését, ami a nyugati piacok elérhetősége miatt tovább növelte a magyar mezőgazdasági termékek iránti igényt (Vágás 1982). Emellett az egyre inkább pusztítóbb árvizek korlátozták a városok fejlődését. A magyarországi Felső-Tisza szabályozása az 1750-es és 1770-es árvizek után került napirendre, de a megoldás szükségességét gyorsították az 1815-16-os és az 1830-as pusztító árvizek is (Vágás 1982). Széchenyi István 1845-ös Tisza menti útja során felismerte, hogy nem csak a magyarországi Felső-Tisza szabályozása sürgető, hanem a Közép- és Alsó-Tiszáé is (Botár és Károlyi 1971). A szabályozás szükségessége nem csupán a Tisza mentén fogalmazódott meg, hanem a mellékfolyók mentén is, amelyeknek nagy szerepe volt/van a Tisza árvízszintjeinek befolyásolásában. A Tisza-völgy, mint egységes fogalom Széchenyi Istvántól ered, aki a megvalósítás sikerét abban látta, ha nem csak a Tisza mentén létesülnek árvízvédelmi töltések és kanyarulat-átvágások, hanem annak mellékfolyói mentén is (Botár és Károlyi 1971).

A szabályozási tervek elkészítésére Széchenyi István Vásárhelyi Pált kérte fel. A Tisza szabályozásának két fớ célja volt. Egyrészt az árvízvédelmi töltések kiépítésével az egykori ártéri területek ármentessé tétele, másrészt a folyómeder rendezésével az árvizek levonulásának gyorsítása (Botár és Károlyi 1971, Ihrig 1973, Vágás 1982). Vásárhelyi figyelembe vette azt a tényt, hogy a Tisza alsó szakaszán nagyon kicsi az esés és a kanyarulatok lassan fejlődnek, valamint hogy a Körös és a Maros visszaduzzasztó hatása miatt jóval szélesebb töltéstávolság kialakítása szükséges. Javaslata az volt, hogy a töltések kialakítását a folyó felső szakaszán, míg a kanyarulatok átvágását az alsó szakaszon kezdjék el (Vágás 1982). A munkálatok 1846. augusztus 7.-én kezdődtek Tiszadobnál, azonban az 1848-49-es forradalom és szabadságharc egy időre megakasztotta a munkálatokat (Vágás 1982). Vásárhelyi Pál halálát követően, az 1850-es években újra meginduló munkálatok kezdtek egyre jobban eltérni az egyébként müszakilag jó tervektől (a helyzetet tovább bonyolították Paleocapa elképzelései), mind a töltések kialakítása, mind pedig a kanyarulatok átvágása kapcsán. Míg a folyószabályozás az állam feladata lett, addig az árvízvédelmi töltések kialakítása a társulatok felelőssége volt, amelyre az állam egyre kevesebb támogatást adott (Dégen 1969). Így a kivitelezők a lehető legolcsóbb megoldásokkal igyekeztek megvalósítani a kiépítést. Ez pedig gyakran a Vásárhelyi által készített tervek bizonyos kikötéseinek egyre gyakoribb elhanyagolásával járt. A kanyarulatok átvágása (mivel állami feladat volt) nem a töltések kialakításával összhangban valósult meg, ahogy azt Vásárhelyi javasolta. Az Alsó-Tisza mentén figyelmen kívül hagyták azt a tervet, miszerint a kötöttebb mederanyag és a lassabb kanyarulatvándorlás miatt szélesebb vezérárkok kialakítása szükséges. Ennek eredménye pedig az lett, hogy a Csongrádtól délre fekvő területeken az átvágások majdnem teljes egésze sikertelen lett (Dégen 1969). További gondot jelentett, hogy a felső szakaszokon a könnyebben kifejlődő átvágások miatt a meder esése megnövekedett és az árvizek is gyorsabban kezdtek el levonulni, azonban az alsó szakaszok kisebb esése és kanyargósabb volta miatt a víz jobban feltorlódott, így egyre inkább növelve a töltésszakadások és pusztító árvizek kialakulásának veszélyét (Lászlóffy 1969). Ennek eredményeként következett be 1879. március 12.-én a szegedi árvízi katasztrófa. Az árvíz legnagyobb tanulságai a folyószabályozás és az árvízvédelem rendszertelen, szervezetlen és nem összehangolt munkája, valamint a laza állami ellenőrzés voltak. A szegedi árvíz után megteremtődött a szabályozás törvényi háttere (Botár és Károlyi 1971), 1886-ban pedig árvízjelző szolgálatot hoztak létre, valamint a Tisza fejlődésének nyomon követésére megalapították a Vízrajzi Osztályt (Lászlóffy 1969).

A Tisza XIX. századi szabályozása összességében az egyik legjelentősebb munkálatnak számított európai viszonylatban. A Tiszaújlak és Titel közötti szakaszon összesen 112 kanyarulatot vágtak át, így az eredetileg 1214 km hosszú szakasz hossza 37\%-kal (761 km-re) csökkent (Botár és Károlyi 1971). Összesen $2940 \mathrm{~km}$ hosszú töltésrendszer épült, amely eredményeként $16500 \mathrm{~km}^{2}$-nyi terület vált ármentessé (Dunka et al. 1996, Somogyi 2000). Mivel kezdetét vette az árvízvédelmi töltések folyamatos, tervszerü kiépítése és megerösítése és, az árvízszintek ugrásszerủen megemelkedtek: a munkálatok megkezdése előtt a legmagasabb vízállások 600-640 cm körül mozogtak, míg 1879-ben Szegeden már $806 \mathrm{~cm}-\mathrm{t}$ mértek. Emiatt a töltések folyamatos karbantartást igényelnek és méretezésük folyamatos módosítása szükséges 
(Lászlóffy 1969). Az átlagos esés 3,8 cm/km-ről 5,9 cm/km-re növekedett (Lóczy et al. 2009), amely megnövelte a mederben a víz munkavégző képességét. Ez egyrészt a meder bevágódásához vezetett, ami a kisvízszintek több mint 2 méteres csökkenését okozta (Pécsi 1969, Botár és Károlyi 1971), másrészt a folyó medermintázatának megváltozását eredményezte, amely kanyarogva feltöltődőből kanyarogva bevágódóvá vált (Somogyi 2000).

A Tisza nagyvízi mederrendezését követően megkezdődött a folyó kisvízi szabályozása, amelyet a meder XIX. századi szabályozását követő változásai és a hajózás igényei tettek fontossá (Iványi 1948). A hajózás szempontjából fontos medermélységet rőzsesarkantyúk kiépítésével biztosították, amelyek mederszükítő hatására a meder kimélyült. A kanyarulatok túlzott továbbfejlődését (amely számos helyen a kiépült árvízvédelmi töltéseket veszélyeztette) pedig partbiztosítások kiépítésével állították meg (Iványi 1948). A Tisza árvizeinek megemelkedése és a kisvizek csökkenése a vízjárási szélsőségeket növelte, és ennek, illetve a kisvizes időszakok negatív hatásainak csökkentését célozzák a duzzasztók. A folyón összesen három épült: 1954-ben Tiszalökön, 1973-ban Kiskörén, 1977-ben pedig Törökbecsén helyezték üzembe a duzzasztómüveket (Rakonczai és Kozák 2009).

A Tisza szabályozásának 20-21. századi lépése a Vásárhelyi Terv Továbbfejlesztése, amelynek kiemelt célja a nagyvízi meder vízszállító képességének javítása, illetve az árvízszintek 1 m-rel való csökkentése, amelynek megvalósítására összesen 6 árvízi vésztározó kiépítése valósult meg. A Nemzeti Vízstratégia (Kvassay Jenő Terv) 2014 és 2020 között további 3 vésztározó kiépítését célozza a Tisza magyarországi szakasza mentén, továbbá kiemelt célként határozza meg a nagyvízi mederkezelés megvalósítását 2020-ig, amely a meglévő töltések fejlesztését, illetve a hullámtér vízvezető-képességének javítását foglalja magába.

\subsubsection{Armentesítési és mederszabályozási munkálatok és azok következményei az Alsó- Tisza mentén}

Az Alsó-Tisza mentén 1855 és 1889 között összesen 10 kanyarulatot vágtak át (Pálfai 2001), amely a folyószakasz eredeti 105 km-es hosszát 19 km-rel rövidítette le (Ihrig 1973). Az Alsó-Tisza mentén a töltéseket az 1880-as évek elején építették, azonban azóta többször is megmagasították őket (a legutolsó töltésmagasítás 2019-ben valósult meg Szentes-Mindszent térségében). A kezdetben 4,5 m magas és 19,5 m talpszélességü tiszai töltések mára $7 \mathrm{~m}$ magasak és $62 \mathrm{~m}$ szélesek (Schweitzer 2001b). Az árvízvédelmi töltések kiépítésével az egykor 6-8 km széles hullámtér átlagosan 1 km-re szükült, de például Szegednél csupán 400 m széles (Amissah et al. 2017). Az 1930-as években intenzív mérnöki beavatkozások kezdődtek (Iványi 1948), a legtöbb sarkantyút és partbiztosítást kiépítették az 1960-as évekig (Kiss et al. 2008), de néhány már az 1800-as évek végén megépült, illetve a 20 . század végén is történtek beavatkozások (illetve 2019-ben néhány szakaszon megkezdték a megsemmisülő partbiztosítások újjáépítését). Ennek hatására mára az Alsó-Tisza hosszának 51\%-a partbiztosított (3. ábra). A törökbecsei duzzasztót 1976-ban helyezték üzembe, amelynek célja az Alsó-Tisza kisvizeinek szabályozása és az öntözővíz kivétel megkönnyítése (Rakonczai és Kozák 2009).

A XIX. században végrehajtott kanyarulat-átvágásokat követően a mederesés növekedésének következtében megnőtt a folyó munkavégzö képessége, amely a meder bevágódását és szükülését eredményezte (Károlyi 1960, Ihrig 1973). Az Alsó-Tisza medrének szélessége 1842 óta 16\%-kal csökkent (Fiala és Kiss 2006). Az árvizek növekedéséhez hozzájárult a meder folyamatos szükülése, azonban ebben az esés romlása (Kiss 2014), a kanyarulatok élesebbé válása (Kiss 2014), illetve a hullámtéren zajló kedvezőtlen folyamatok, azaz a növényzet sürübbé válása (Delai et al. 2018) és az intenzív hullámtéri feltöltődés (Sándor 2011) is szerepet játszanak. Mindezek eredményeként 1876 és 2006 között Csongrádnál $440 \mathrm{~cm}$ rel, Szegednél pedig 349 cm-rel emelkedtek a tetőző vízállások (Lóczy et al. 2009).

A meder morfológiájának megváltozása következtében a kisvizek 2-3 m-rel csökkentek (Lászlóffy 1982, Somogyi 2000, Rakonczai és Kozák 2009). A törökbecsei duzzasztó megépítése elött az LKV Csongrádnál $-344 \mathrm{~cm}$, Mindszentnél $-293 \mathrm{~cm}$, Szegednél pedig $-250 \mathrm{~cm}$ volt. Az 
1976-ban üzembe helyezett törökbecsei duzzasztómü hatására azonban a kisvizek szintje ma már nem igen csökken a vízmércék '0' pontja alá (Rakonczai és Kozák 2009).

A kanyarulatok átvágását követően a folyó igyekezett újra egyensúlyi állapotba kerülni, és a megnövekedett munkavégző képességét a kanyarulatok továbbfejlesztésére fordította. Emellett az új, kiegyenesített szakaszokon is megindult a kanyarulatok fejlődése (Kiss et al. 2008, Lóczy et al. 2009). Ezt jelzik, hogy például az Alsó-Tisza mindszenti szakaszán 1842 és 1999 között a folyó hossza 1,4\%-kal nőtt (Kiss et al. 2008). A XIX. századi szabályozási munkák után a kanyarulatok továbbfejlődése felgyorsult, ami azonban veszélyeztette a töltéseket, amely elsősorban a jobb parti hullámtéren okozott gondot, ugyanis itt az árvízvédelmi töltés nagyon közel fut a folyóhoz, egyes helyeken csupán $50 \mathrm{~m}$ a gát és a meder távolsága.

A partbiztosítások kiépítésének hatására módosult a meder geometriája, hiszen a külső ív elmozdulása jelentősen lelassult, helyenként meg is állt, míg a belső íven folytatódott az övzátonyok épülése, amely a meder szélességének $12 \%$-os csökkenését eredményezte az 1930-as évek óta (Fiala és Kiss 2005, Kiss et al. 2008, Sipos et al. 2007). A meder szükülésével a sodorvonal egyre közelebb került a partbiztosított oldalhoz, a mederszükülés fokozódásával később pedig a belső ívhez is. Fiala és Kiss (2005) számításai alapján a sodorvonal külső ívtől való átlagos távolsága 1890 -ben $27,5 \mathrm{~m}$ volt, a belső ívhez pedig $100 \mathrm{~m}$ közel helyezkedett el. Ez a távolság 2001-ig 17,2 m-re csökkent a külső íven, a sodorvonal belső ívtől való távolsága pedig már csak 53,5 m volt. Másrészt csökkent a meder szelvényterülete is, amely alapvető szerepet tölt be az árvizek levezetésében, ugyanis a szelvényterületben bekövetkező bármilyen változás hatással van a tetőző vízállások magasságára és a vízhozamokra is (Kiss et al. 2008). Az 1890 és 2001 közötti időszakban, az Alsó-Tisza egyes szelvényeiben 6,2-19,3\%-kal csökkentek a mederkitöltő vízálláshoz tartozó vízhozamok (Fiala és Kiss 2005, Kiss et al. 2008). A meder bevágódása és a sodorvonal parthoz való közelebb kerülése miatt csuszamlásos folyamatok indultak meg nem csak a kanyarulatok külső ívén, de a belső oldalon is. Emiatt módosult az övzátonyok fejlődése is, hiszen az aktívan épülő övzátonyok száma a felére (47-ről 20-ra), összhosszuk pedig a tizedére (52,3 km-röl 4,7 km-re) csökkent (Kiss et al. 2018a, 2019b). Jelenleg az Alsó-Tisza hosszának 65\%-át érinti a parterózió. A folyó a partbiztosított szakaszokat is elkezdte megbontani, amelynek hatására a kőrakatok 58\%-a bizonyos fokig károsodott (Kiss et al 2019b).

A kanyarulat-átvágások következtében megnőtt munkavégző-képesség a lebegtetett és fenékhordalék hozamának növekedését is eredményezte. Ez a megnőtt hordalékmennyiség a töltések kiépítése után a leszükített hullámtéren indult intenzív felhalmozódásnak (Lóczy et al. 2009), amely azonban az ármentesítési munkálatok egy addig nem várt következménye volt (Károlyi 1960). Az eredetileg 0,02-0,05 cm/év ütemü természetes ártér-feltöltődés (Félegyházi 2008) átlagosan 0,5-1,5 cm/évre gyorsult (Sándor és Kiss 2006, 2007). A 20. század során a hullámtér-feltöltődés ütemének gyorsulásához hozzájárult egyrészt a felszínborítás megváltozása, ugyanis a rétek és legelők helyén általánossá vált az erdők telepítése (Oroszi 2009). Másrészt intenzív terjedésnek indultak az invazív növényfajok is, amelyek a parlagon hagyott szántókon, illetve az ültetett erdőkben tudnak a legkönnyebben elszaporodni. Utóbbiak esetén az ültetést követő 4-5 évben felhagyják az erdők gondozását, és a gyér lombkorona, valamint a bolygatott talaj nagyban elösegíti például az invazív gyalogakác terjedését (Kiss et al. 2019c). A hullámtéren egyre sürübbé váló növényzet a vízáramlás lelassulását eredményezi, amely akár $0 \mathrm{~m} / \mathrm{s}-\mathrm{ra}$ is lecsökkenhet (Sándor 2011), ennek hatására pedig fokozódhat a hordalék felhalmozódása a hullámtéren. A hordalék felhalmozódása miatt romlik a hullámtér vízszállító képessége, hiszen a feltöltődés csökkenti az árvizek levezetésére szolgáló hullámtéri térfogatot (Jakucs 1982, Nagy et al. 2001). A vízszállító képesség csökkenésének mértéke árvizenként igen eltérő: az 1998-99. és a 2000. évi árvizet követően 0,89 és $0,09 \%$-os csökkenést mértek Mindszent térségében, ami nagyságrendi különbséget jelez (Kiss et al. 2002). 


\section{Kutatási módszerek}

\subsection{A hullámtér-feltöltődés mértékének meghatározása}

A 19. századi árvízvédelmi töltések kiépítése óta zajló feltöltődést a jelenlegi aktív hullámtér és a gátak mögötti mentett ártéri területek abszolút magasságkülönbsége alapján határoztam meg, Gábris et al (2002) és Kiss et al. (2011) módszertanát követve. A kiindulási koncepció az, hogy a mentett ártéri területek magassága megfelel a gátépítés előtti felszínnek, amely jó viszonyítási alapot jelent a hullámtéri területek feltöltődésének meghatározásában. Az aktív hullámtéri területekről rendelkezésemre állt egy nagy felbontású $(0,5 \mathrm{~m}$ x $0,5 \mathrm{~m}$; vertikális pontosság: $\pm 10 \mathrm{~cm}), 2014$-ben készült LiDAR felvételezés alapján készült domborzatmodell. A töltések mögötti területek esetében az 1979-1985 között készült topográfiai térképezés alapján létrehozott, $5 \mathrm{~m} \times 5 \mathrm{~m}$-es felbontású digitális domborzatmodellt használtam fel (vertikális pontossága $\pm 45 \mathrm{~cm}$ ). Mindkét domborzatmodellt az Alsó-Tisza-vidéki Vízügyi Igazgatóság biztosította számomra.

Az alapvető célom az volt, hogy elöre meghatározott területegységekben számszerüsítsem a magasságkülönbségeket a folyó jobb és bal partján egyaránt. A Maroson végzett hasonló kutatás alapján (Kiss et al. 2011) a területegységeket elválasztó határvonalakat először egymással párhuzamosan szerettem volna felvenni, azonban a Tisza jóval kanyargósabb volta miatt ez a megoldás nem bizonyult megfelelőnek. Azért, hogy közel egyenlő nagyságú területek legyenek összehasonlíthatók, a közöttük lévő határvonalakat a hullámtér középvonalára közel merőlegesen szerkesztettem, egymástól 1-1 km-re. Ezzel a módszerrel összesen 86 területegységet határoltam le (4. ábra), amelyek mindegyike négy részből áll (5. ábra): jobb parti mentett ártér (a) és hullámtér (b), valamint bal parti hullámtér (c) és mentett ártér (d). A területegységeket Global Mapper 17 programmal vágtam ki, míg azokon belül a magassági adatok kiértékelését ArcGIS 10.1 ZonalStatistics eszközével számítottam ki.

A mentett oldali területeken, ahol lehetőség volt rá igyekeztem közel $1 \mathrm{~km}^{2}$ területü polygonokat kialakítani (5. ábra). Azonban ennél nagyobb egységeket nem tartottam célszerünek felvenni az eredeti ártéri felszín antropogén módosultsága miatt, hiszen a mentett oldalon előfordulnak olyan természetes, de legföképpen mesterséges objektumok, amelyek a magassági adatok alul- vagy felülbecslését eredményezhetik. Az átlagmagasság túlbecslését okozhatják a másodlagos árvízvédelmi töltések, nyári gátak, kiemelt utak és hidak, míg a mesterséges csatornák, bányagödrök és a nyílt vízfelszínek (pl. mesterséges tavak, holtágak) pedig az adatok alulbecslését eredményezhetik. Azért, hogy létrehozott területegységek magassága a lehető legpontosabb legyen, a fentebb említett objektumokat kimetszettem a területegységeket lefedő polygonokból. A vízfelszíneket azért tartottam célszerünek kivenni a számításokból, mert - habár ezek is részt vehetnek a hullámtéri akkumulációban -magassági adataik a domborzatmodelleken a számolás során torzított adatokhoz vezethetnek.

A mentett ártér és a hullámtér közötti magasságkülönbség meghatározása nem volt közvetlenül lehetséges az olyan esetekben, amikor a mentett ártéri területnek nagyobb volt a tengerszint feletti magassága. Ennek két esete fordult elő a mintaterületen: (1) csak az egyik oldali mentett ártér volt magasabb, vagy pedig (2) mindkét mentett oldal magasabb volt, mint a hullámtér, de az egyik magasabb szint szigetszerüen emelkedett ki. A mintaterület fejlödéstörténetéből adódóan (Hernesz 2015) a mentett ártéri felszíneket (A-szint) magasabb ártéri szintek határolják, amelyekre helyenként a gátakat építették (T39-53), illetve nyugat felől a Pilis-Alpári-homokhát szegélyezi, ami helyenként a hullámtérig nyúlik (T1-11). Olyan eset, hogy mindkét hullámtéren kívüli terület magasabb legyen, mint a hullámtér, csak két sáv (T4243) esetében fordult elö, de itt a nyugati mentett oldalon az ártéri szint fölé 3-5 m-rel emelkedő ártéri sziget emelkedett (Hernesz 2015). A fentebb említett természetes magaslatok mellett előfordult olyan helyzet is (pl. Szegednél: T76-78), ahol a település beépítettsége és a felszín antropogén megmagasítása miatt a mentett ártér magassága nem volt meghatározható semelyik oldalon sem. 


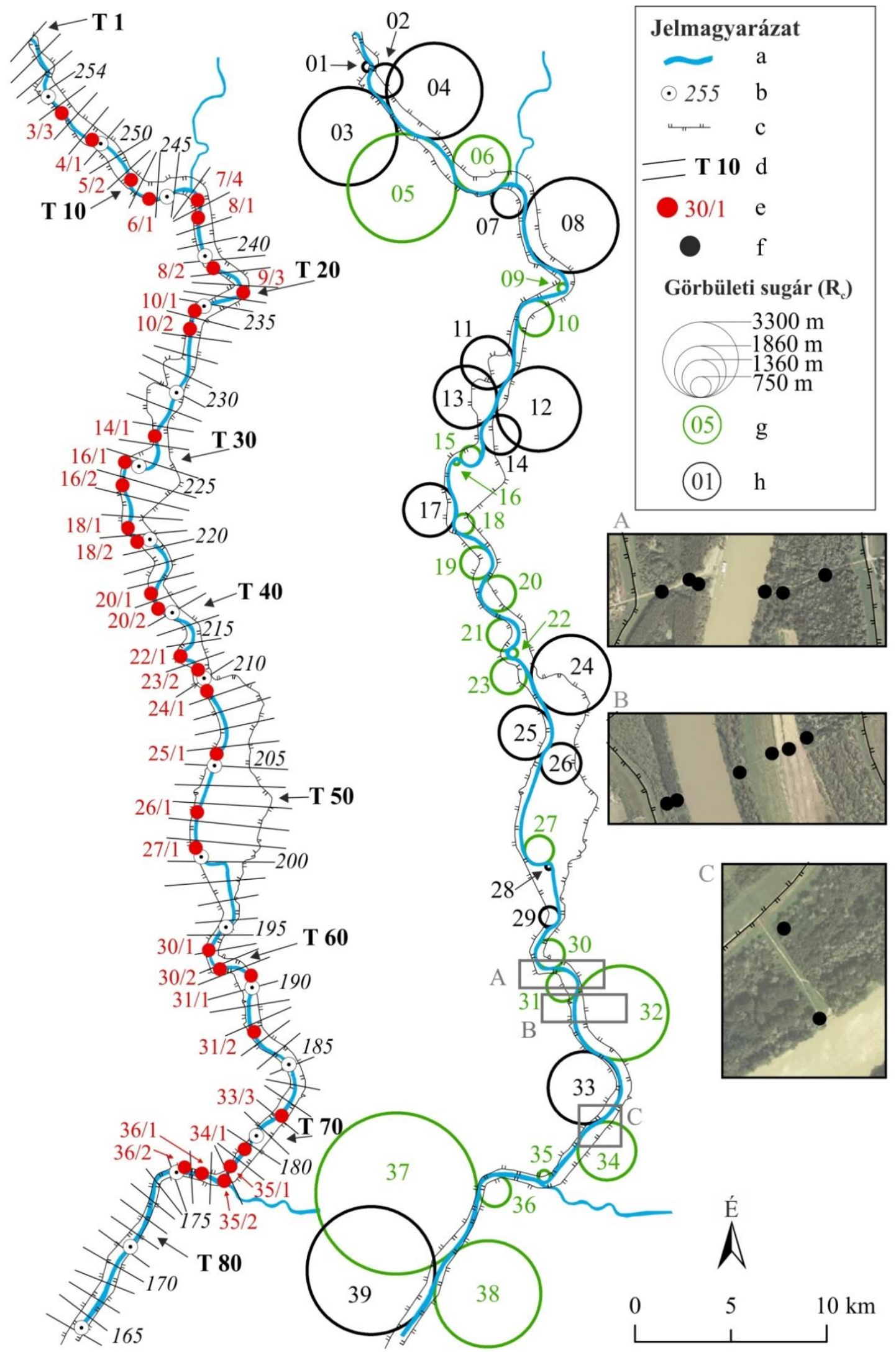

4. ábra. A hullámtér-feltöltödés méréséhez alkalmazott területegységek (T1-86), az üledékminta-vételi pontok (piros pöttyök, a számok arra utalnak, hogy melyik kanyarulat folyóhátjáról származik a minta), a mintaterületen vizsgált kanyarok és azok görbületi sugara $\left(R_{c}\right)$, illetve a növényzetröl készül fényképek térbeli elhelyezkedése $(A-C)(a$ : Tisza, $b$ : folyamkilométer, c: árvízvédelmi töltés, d: hullámtéri területegység, e: üledékminta-vételi pontok, $f$ : hullámtéri növényzetröl készült fényképek helye, g: szabályozások elött is létezö kanyarulatok, h: a kiegyenesitett szakaszokon fejlödésnek indult kanyarulatok) 
A 86 területegység közül 34 esetében jelentett gondot a mentett ártér magasságának meghatározása. A probléma kiküszöbölése céljából a következő megoldásokat alkalmaztam. Azon szelvények esetében, ahol

(1) csak az egyik oldali mentett ártér magasabb, ott a szemközti oldali mentett ártér magasságát vettem figyelembe.

(2) mindkét oldal magasabb volt, és egyik oldalon a fentebb említett ártéri sziget akadályozta az elemzést, ott a sziget mögötti egykori ártéri felszín magasságát vettem figyelembe mindkét mentett oldal esetében.

(3) a sürün beépített és erősen módosított felszínek esetében egyáltalán nem volt meghatározható a mentett oldal magassága, illetve egy területegységben a jobb oldali hullámtér gyakorlatilag 0 m-es szélessége miatt csupán a bal oldali hullámtér magassága volt meghatározható. Ezeket a területegységeket így kihagytam a mérésekböl, ami a későbbiekben hátrányt jelenthet, hiszen ezek az egységek elsősorban a Maros torkolata alatt találhatók, így a Maros feltöltődésre gyakorolt hatása ezekben nem volt vizsgálható a mentett területek magasságához viszonyítva.

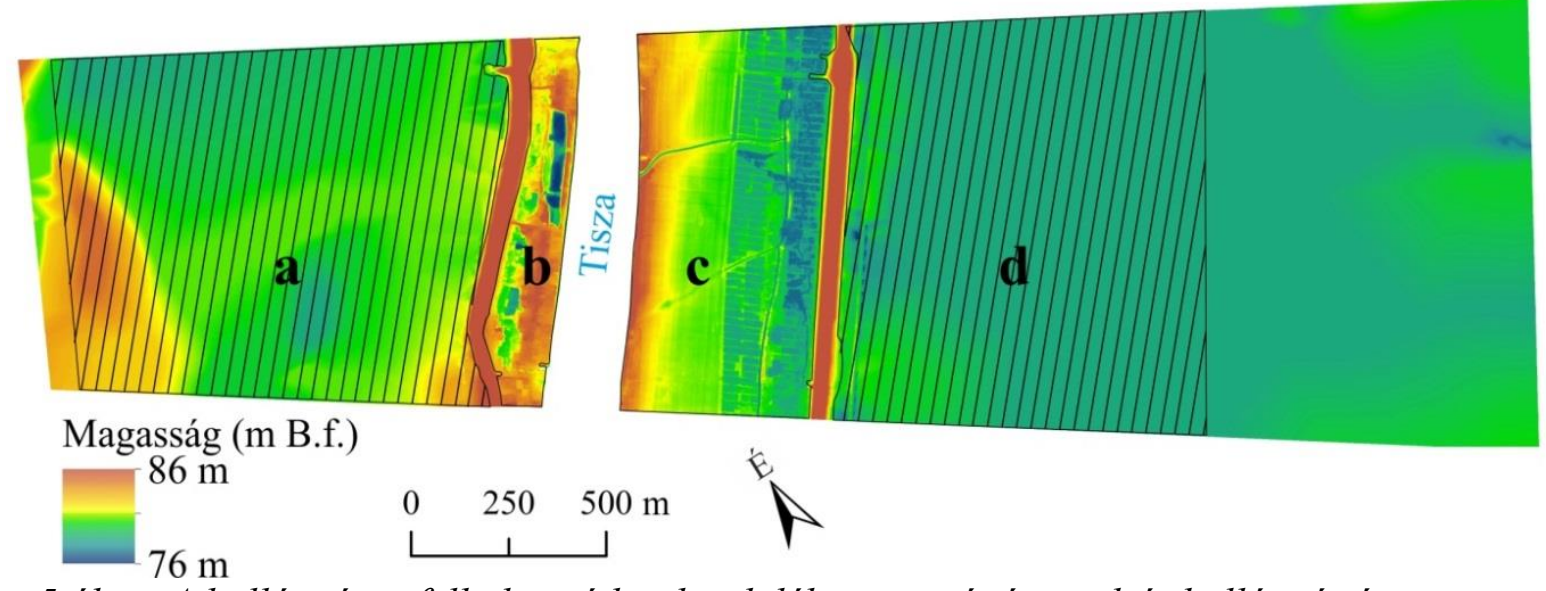

5.ábra. A hullámtéren felhalmozódott hordalék vastagságát az aktív hullámtér és a mentett ártéri területek magasságkülönbsége adja meg (a: jobb oldali mentett ártér, b: jobb oldali hullámtér, c: bal oldali hullámtér, d: bal oldali mentett ártér)

A hullámtér és a mentett ártéri területek közötti magasságkülönbség alapján kapott hordalékvastagság adatokat felhasználtam a hullámtér vízszállító-képességének csökkenésének kiszámításához. A vízszállító-képesség csökkenését a hullámtér és a felhalmozódott hordalék térfogata különbségeként határoztam meg. A hullámtér tárfogatát a LiDAR felmérés alapján azonosított töltésmagasság és a hullámtér területének szorzata adta meg, míg a felhalmozódott hordalék térfogatát úgy számítottam ki, hogy minden területegységen belül a hordalék vastagságát megszoroztam az adott területegységben a hullámteret lefedő polygon területével.

\subsection{A folyóhátak vizsgálata}

A folyóhátak méreteit (magasság és szélesség) a 2014-es LiDAR felvétel alapján elkészült DDM-en vizsgáltam. A folyóhátak korábbi méreteire vonatkozóan nincsenek megbízható magassági adatok.

A folyóhátak legnagyobb relatív magasságát a mentett ártéri területek átlagmagasságához viszonyítva határoztam meg. Attól függően, hogy a folyóhát hol alakult ki a kanyarulat mentén, a kanyarulatok felső-, középső- és alsó-harmadában megkerestem a forma legmagasabb pontját, és ennek a relatív magasságát számoltam ki (6. ábra). Nagyméretü kanyarulatok mentén, vagy hosszú folyóhátak esetén több harmadban is lemértem a formák magasságát. Ugyanezen 
pontokban megmértem a folyóhátak szélességét is a felszínröl készített keresztmetszet alapján. A folyóhát peremét a partél és azon pont között határoztam meg, ahol a folyóhát az ártérbe simul, azaz ahol a felszín lejtése $\leq 1^{\circ}$ (7. ábra).

A folyóhátak magassága és szélessége mellett kiszámítottam a hordalék

lerakódásának ütemét is. Ennek meghatározása bonyolultabb feladat, ugyanis egyrészt a Tisza számos szakaszon jelentősen leszükült, másrészt pedig egyes kanyarulatok fejlődése tovább folytatódott, miközben futásuk kis mértékben megváltozott, ami módosíthatta a hordalék part menti lerakódását is.

A folyóhátak kialakulásának kezdete $(K)$ alapján 3 csoportot lehet megkülönböztetni: (1) Vannak olyan formák, amelyek kialakulása a 19. századi kanyarulat-átvágások során kialakított vezérárok mentén indult meg, így ezek fejlődésének kezdete az adott kanyarulat átvágásának évére tehető. (2) Előfordulnak szükülő mederszakaszok mentén fejlödő folyóhátak. Ebben az esetben a korábbi aktív akkumulációs part menti sáv a medertől kissé távolabb került, és a mindenkori partél menti terület vált aktívvá. Ilyen esetben a folyóhát korát az adott partszakasz ártéri felszínként való ábrázolásának ideje alapján adtam meg. Ehhez a

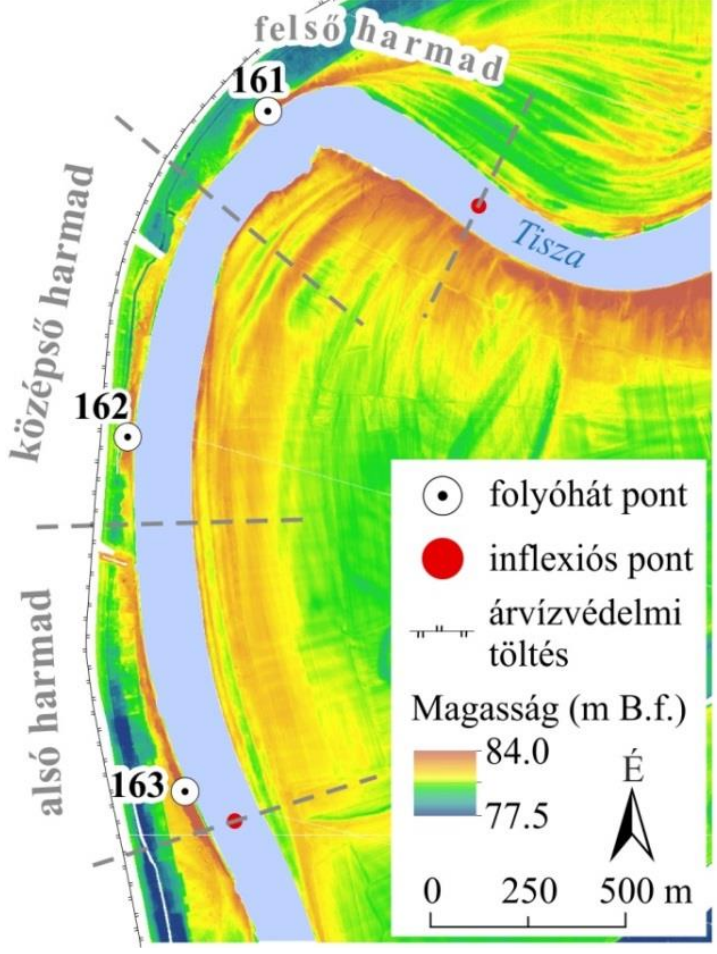

6. ábra. A folyóhátak morfológia tulajdonságait a kanyarulatok felsö, középsö és alsó harmadában vizsgáltam különböző rendszerességgel készült Tisza felméréseket (1838, 1890, 1929 és 1976) használtam fel. Tehát ha egy, a DDM-en megjelenő folyóhát gerince az 1890-es felméréskor még a mederben lett volna, de az 1929-es felmérésen már a partélen kívülre esett, akkor a folyóhát épülése a két időpont között kezdődhetett el, de biztosan csak 1929-ben, így az 1929-es évet vettem kialakulása kezdetének. Végül (3) léteznek olyan folyóhátak, amelyek esetében a partél helyzete alig változott a „,Tisza hajdan és most” 1838-1842-es készülése óta, így e formák már legalább 177 évesek.

A folyóhátak feltöltődésének átlagos ütemét $(A)$ a forma épülésének kezdete $(K)$ és 2014 (LiDAR felmérés) közötti időszakra számítottam ki, a forma legnagyobb magassága $(M)$ és kora alapján, majd az eredményeket mm/év-ben adtam meg:

$$
\mathrm{A}=\frac{M}{2014-K}
$$

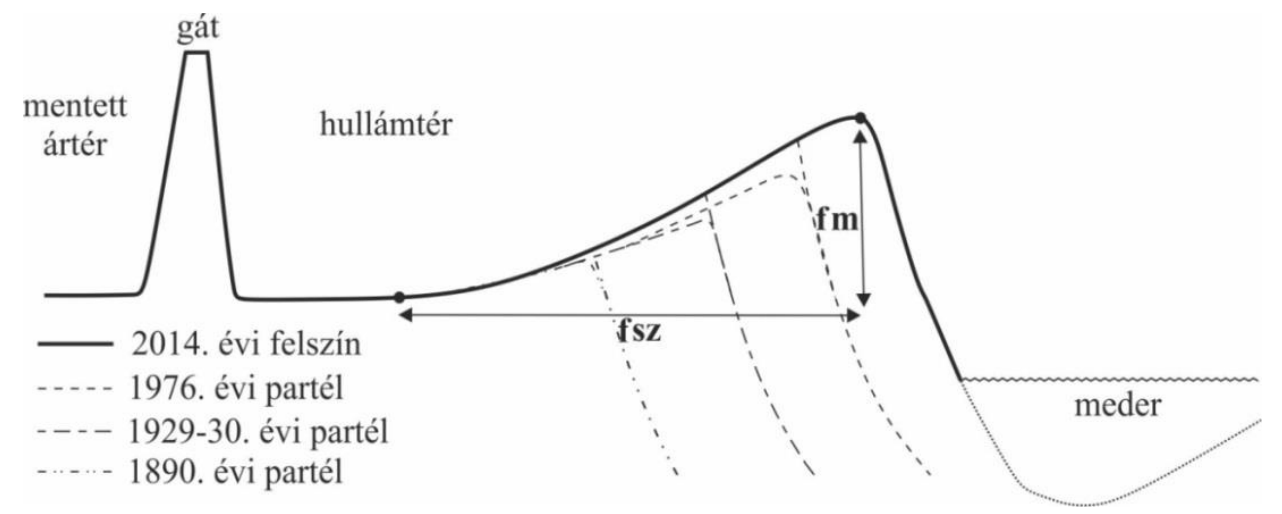

7. ábra. A folyóhát magasságát (fm) a mentett oldal magasságához viszonyitva, szélességét ( $\mathrm{Sz}$ ) pedig a folyóhát legmagasabb és legalacsonyabb pontja alapján határoztam meg. A felhalmozódásuk ütemét az utolsó ismert partél helyzete alapján számitottam ki 
A folyóhátak anyagát 2017 őszén mintáztuk meg, mivel a minták szemcseösszetétele alapján következtetni lehet a hordalék-felhalmozódás körülményeinek térbeli trendjére. A mintavételi pontok kitüzése során szempont volt, hogy az üledéket bolygatástól mentes térszíneken vegyük, és lehetőleg minden kanyarulat folyóhátját mintázzuk meg (4. ábra). Az üledékmintákat a folyóhát rétegsorának felső $5-10 \mathrm{~cm}$-ből vettük, hiszen ezt a réteget feltehetőleg ugyanaz az árvíz rakta le. Egyes folyóhátakat teljes vastagságukban megmintáztunk, lehetőleg az alattuk lévő paleotalaj szintjéig, hogy a lerakódásukkor uralkodó folyóvízi környezetet részben rekonstruálhassam. A kiszárított minták szemcseösszetételét a laborban FritschAnalysette 22 MicroTecPlus lézeres szemcsemérő segítségével határoztam meg.

\subsection{Az övzátonyok vizsgálata}

Az alsó-tiszai övzátonyok morfometriai jellemzői 39 kanyarulat közül csak 33 mentén vizsgálhatók. Ennek oka, hogy van olyan kanyar, ahol nem készült LiDAR felmérés (31-32. sz. kanyarulat), van ahol a felszín nagymértékủ bolygatottsága miatt nem sikerült azonosítani a formákat (36-37. sz.), illetve két álkanyar (12. és 39. sz.) esetén a szabályozások során kiegyenesített szakaszok még olyan kevéssé indultak kanyargásnak, hogy az övzátony nem tudott kialakulni.

Az övzátonyokat a LiDAR felmérés (2014) alapján elkészített DDM-en azonosítottam és ezen adatforrás alapján mértem le morfometriai paramétereiket ArcGIS 10.1 szoftver segítségével. Keresztszelvények alapján meghatároztam az övzátony-sorokat alkotó tagok számát, illetve minden tagnak a mentett ártéri területekhez viszonyított relatív magasságát ( 8 . ábra). Mivel szinte sehol nem lehetett úgy szelvényeket készíteni, hogy az övzátony-sor összes tagja benne legyen, ezért mindig a legfiatalabb övzátony legmagasabb pontjára merőlegesen készítettem metszeteket a hullámtérről. Azon kanyarulatok mentén, ahol az övzátony-fejlődés iránya többször változott (pl. elforduló kanyarulatok esetében), ott igyekeztem mindig az övzátony-sorokra merőleges keresztmetszetet felvenni. Az egyes övzátony-sorok tagjait beszámoztam, a legidősebb forma 1-es számot kapott, onnan pedig a meder felé haladva növekvő értékeket kaptak (8. ábra).
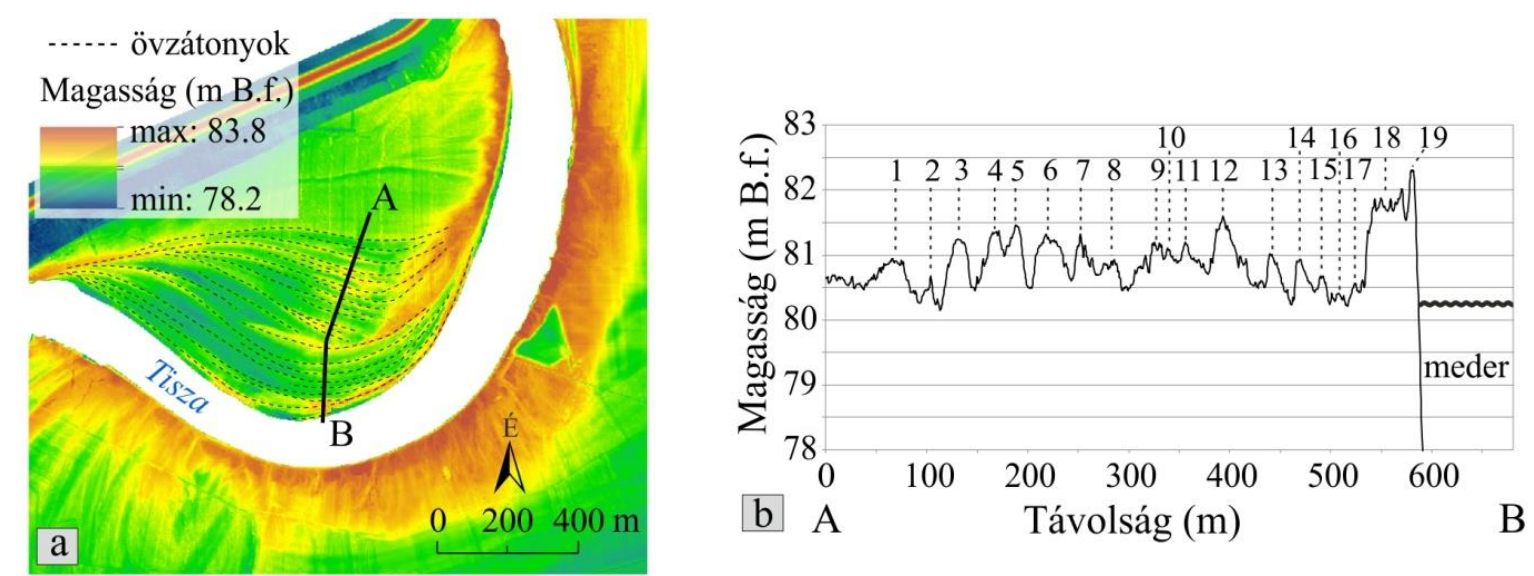

8. ábra. Az övzátony-sorok tulajdonságait egy olyan szelvény mentén mértem le (A-B), amely alkalmazkodott a fejlödési irányukhoz (a). Az övzátony-sorról készitett keresztmetszet (b) alapján végeztem a méréseket

Az egyes övzátonyok relatív magasságán kívül kiszámítottam az egyes formák szélességét és a közöttük lévő távolságot (3. táblázat és 9. ábra).

Az egyes övzátony-sorokat alkotó legutolsó tag és a külső íven fejlődő folyóhátak esetében megvizsgáltam, hogy a formákat magassági viszonyaik alapján milyen magasságú és 
visszatérési idejü árvizek öntik el. Az árvizek visszatérési idejének $\left(\mathrm{T}_{\mathrm{v}}\right)$ kiszámításához a Gringorten formulát alkalmaztam ${ }^{2}$ :

$$
T_{v}=\frac{n+0,12}{m-0,44}
$$

ahol $n$ a felhasznált adatsorban előforduló összes év száma, $m$ pedig adott vízállás érték helye az adatsorban.

3. táblázat. Az övzátonyok és a folyóhátak alaktani jellemzői

\begin{tabular}{|l|l|l|}
\hline Morfológiai jellemzö & Jele & Meghatározás \\
\hline folyóhát magassága & $\mathrm{f}_{\mathrm{m}}$ & $\begin{array}{l}\text { A folyóhátnak az árvízvédelmi töltések mögötti } \\
\text { mentett ártéri terület magasságához viszonyított } \\
\text { legnagyobb relatív magassága (m). }\end{array}$ \\
\hline folyóhát szélessége & $\mathrm{f}_{\mathrm{sz}}$ & $\begin{array}{l}\text { A folyóhát legmagasabb pontja és annak a } \\
\text { pontnak a távolsága, ahol a folyóhát belesimul a } \\
\text { hullámtér felszínébe. }\end{array}$ \\
\hline Folyóhát feltöltődési üteme & $\mathrm{A}$ & $\begin{array}{l}\text { A folyóhát legnagyobb magasságának és korának } \\
\text { hányadosa (mm/év). }\end{array}$ \\
\hline övzátony relatív magassága & $\ddot{O}_{\mathrm{m}}$ & $\begin{array}{l}\text { A mentett ártéri oldal magasságához viszonyított } \\
\text { magasság (m). }\end{array}$ \\
\hline övzátony szélessége & $\ddot{\mathrm{o}}_{\mathrm{sz}}$ & $\begin{array}{l}\text { Az adott formát két oldalról határoló mélyedés } \\
\text { (sarlólapos) legmélyebb pontjai közötti távolság } \\
\text { (m). }\end{array}$ \\
\hline övzátony-formák távolsága & $\ddot{\mathrm{o}}_{\mathrm{t}}$ & $\begin{array}{l}\text { Két szomszédos övzátony legmagasabb pontjai } \\
\text { közötti távolság az idősebbtől a fiatalabb felé } \\
\text { mérve (m). }\end{array}$ \\
\hline
\end{tabular}

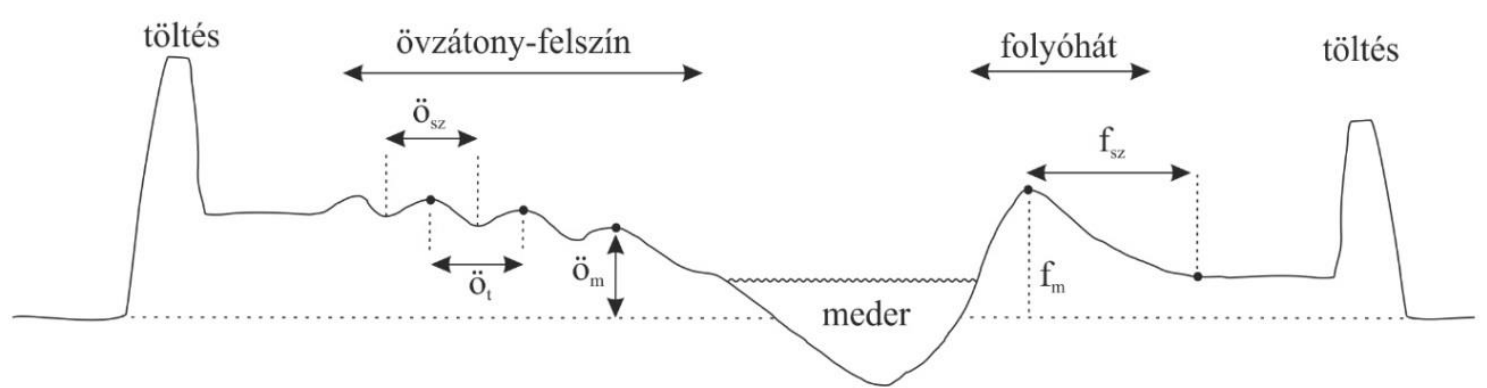

9. ábra. Az övzátony-sorokat alkotó övzátonyok és a folyóhátak vizsgált morfológiai jellemzői: $\ddot{o}_{s z:}$ övzátony szélessége, $\ddot{o}_{m}$ : övzátony magassága, $\ddot{o}_{t}:$ övzátonyok távolsága, $f_{s z}$ : folyóhát szélessége, $f_{m}$ : folyóhát magassága

\subsection{A hullámtér feltöltődését, a folyóhátak és az övzátonyok fejlődését befolyásoló tényezők}

\subsubsection{A hullámtér és a kanyarulatok paramétereinek meghatározása}

A feltöltődés vizsgálatához használt területegységekben megmértem a hullámtér jobb és baloldali, illetve teljes átlagszélességét, továbbá a meder átlagos szélességét is meghatároztam a különböző időpontokban (4. táblázat). Ezen kívül megnéztem, hogy van-e az adott szakaszon partbiztosítás és azt mikor építették.

\footnotetext{
${ }^{2}$ http://www.whycos.org/fck_editor/upload/File/Pacific-

HYCOS/Surface_Waters/Estimating_Flood_Frequency.pdf 2019.12.07.
} 
Az Alsó-Tisza vizsgált szakaszán (255,4-164,7fkm) összesen 39 kanyarulat található (4. ábra), amelyeknek lemértem morfometriai paramétereit a 2014-es felmérés adatai alapján ArcGIS 10.1 szoftverkörnyezetben. A kanyarulatoknak megmértem a görbületi sugarát, valamint az ív- és húrhosszát (4. táblázat), illetve a sodorvonal parttól való távolságát is, amelyet az 1976. évi felmérés VO-szelvényei alapján határoztam meg, és amit a 2017-es mederfelmérés alapján pontosítottam.

A kanyarulatok ív- és húrhosszának hányadosa a kanyarulatok fejlettségét ( $\beta$ ) adja meg, amit a folyóhátak vizsgálatánál használtam fel. A különböző fejlettségi típusok megkülönböztetéséhez Laczay (1982) csoportosítását alkalmaztam.

Az övzátony-sorok fejlődését jelentősen befolyásolja a kanyarulat-vándorlás mértéke. Ezért kiszámítottam ennek sebességét a 18. század vége óta rendelkezésre álló katonai felmérések (1784, 1861) és vízrajzi térképek (1890, 1929 és 1976), továbbá a LiDAR felmérés (2014) alapján. A III. Katonai felmérést (1881-1884) és az 1980-as évek elején készült topográfiai térképet nem használtam fel, mivel ezek időben nagyon közel állnak az 1890. illetve az 1976. évi meder-felmérésekhez (Tisza Atlasz, 1978), amelyek célja kifejezetten a meder pontos felmérése volt. A kanyarulatvándorlás sebességének meghatározásához kiszámítottam az egymást követő felmérések között, hogy milyen ütemmel mozdult el a kanyarulat külső és belső íve, illetve ezzel együtt hogyan változott a meder átlagos szélessége a vizsgált kanyarulat mentén. Azért, hogy ezt minél pontosabban meg lehessen határozni, kanyarulatonként polygonokat hoztam létre két egymást követő felmérés partvonalai között a külső és belső íven is. Majd ezeknek a polygonoknak kiszámítottam a területét, és elosztottam a polygon középvonalának hosszával. A kapott értéket elosztottam a két felmérés között eltelt évek számával, így eredményül megkaptam, hogy mennyi volt a kanyarulat két íve mentén az átlagos partelmozdulás üteme (m/év). A negatív értékek azt jelentik, hogy nem a megszokott irányú a partelmozdulás, azaz negatív érték esetén a külső ív a középvonal felé mozdul el (akkumulációt jelezve), míg a belső ív a középvonaltól távolodik (erodálódik).

4. táblázat. A kutatás során használt kanyarulati és hullámtéri paraméterek meghatározásai (Röviditések: KF: Katonai felmérés, TM: Tisza mederfelmérés, Li: LiDAR felvétel

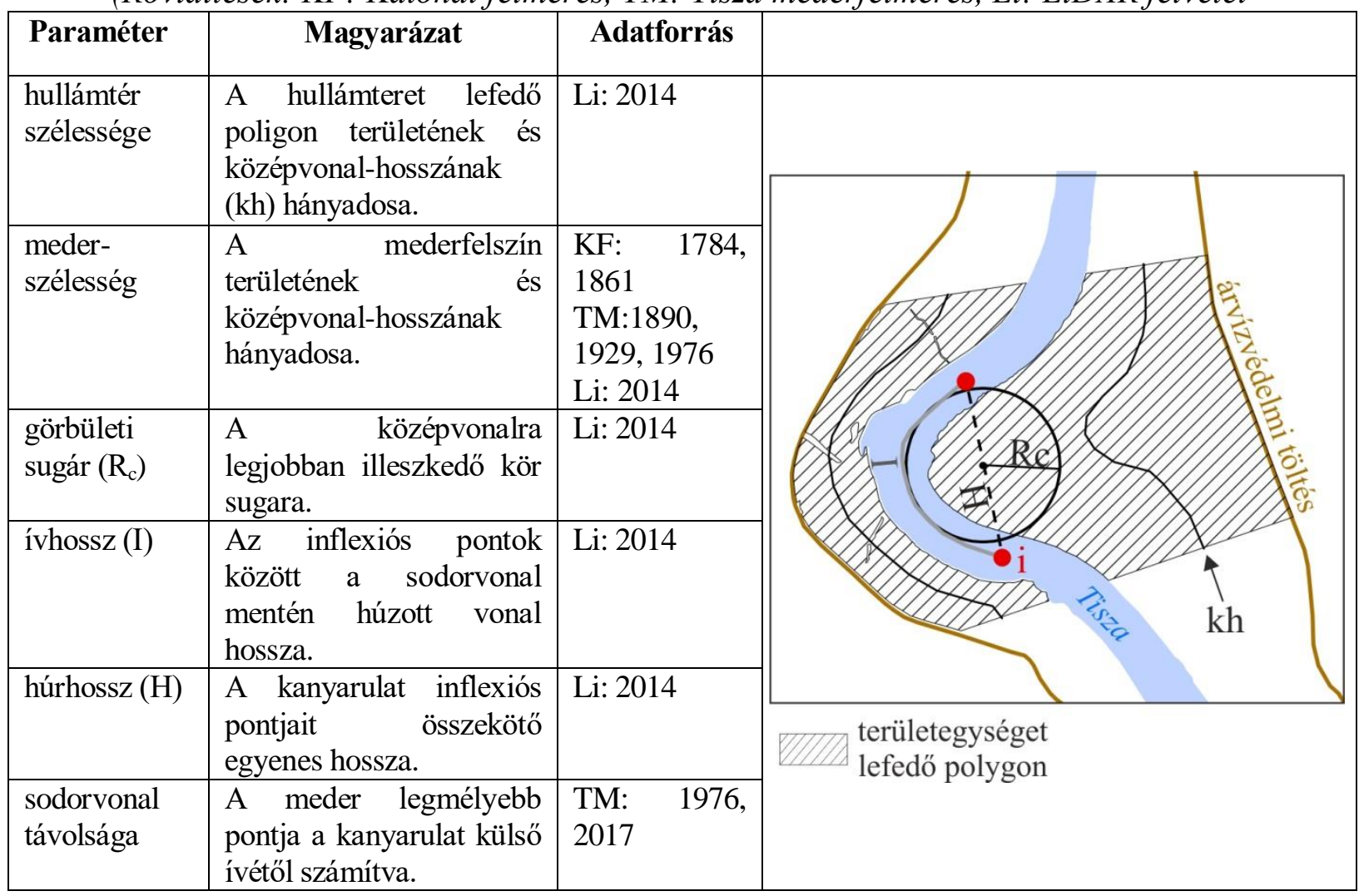




\subsubsection{Felszínboritás és növényzeti érdesség hosszú távú változása}

A mintaterületek hosszútávú felszínborítás-változásának vizsgálatához az 18. század végétől rendelkezésre álló térképeket és egy GoogleEarth müholdfelvételt (5. táblázat) használtam fel. Az adatforrásokat egységes vetületi rendszerbe transzformáltam (EOV), majd 8 felszínborítási kategóriát különítettem el (6. táblázat) ArcGIS 10.1 szoftver-környezetben.

5. táblázat. A felszínboritás-változás vizsgálatához felhasznált térképek és azok jellemzői

\begin{tabular}{|l|c|c|}
\hline & Méretarány & Felvételezés időpontja \\
\hline I. katonai felmérés & $1: 28800$ & 1784 \\
\hline II. katonai felmérés & $1: 28800$ & $1861-1864$ \\
\hline III. katonai felmérés & $1: 25000$ & $1881-1884$ \\
\hline Topográfiai térkép & $1: 10000$ & $1979-1985$ \\
\hline GoogleEarth múholdfelvétel & $1: 2000$ & 2017 \\
\hline
\end{tabular}

Az egyes időpontokra, amikor a felvételezések készültek kiszámítottam a hullámtér növényzeti érdességét is $\left(\mathrm{n}_{\text {év }}\right)$, mégpedig úgy, hogy a Chow (1959) által meghatározott átlagos érdességi értékeket $\left(\mathrm{n}_{1-\mathrm{n}} ; 6\right.$. táblázat) súlyoztam az egyes időszakokban a felszínborítási kategóriák területi arányával $\left(\mathrm{T}_{1-n}\right)$ :

$$
n_{\text {é } v}=\frac{\left(T_{1} \times n_{1}\right)+\left(T_{2} \times n_{2}\right)+\cdots\left(T_{n} \times n_{n}\right)}{T_{1}+T_{2}+\cdots T_{n}}
$$

6. táblázat Az elkülönitett felszínboritási kategóriák és a hozzájuk tartozó irodalmi növényzeti érdesség-értékek (Chow 1959)

\begin{tabular}{|l|c|c|c|}
\hline \multicolumn{1}{|c|}{ felszínborítás típusa } & \multicolumn{3}{c|}{ növényzeti érdesség } \\
\hline vizenyös terület & kategória & $\begin{array}{c}\text { értéke } \\
\text { (min.-max.) }\end{array}$ & $\begin{array}{c}\text { alkalmazott } \\
\text { közepes érdesség }\end{array}$ \\
\hline csupasz felszín & $\mathrm{n}_{1}$ & $0,015-0,019$ & 0,017 \\
\hline erdő & $\mathrm{n}_{2}$ & $0,016-0,020$ & 0,018 \\
\hline rét, legelö & $\mathrm{n}_{3}$ & $0,080-0,120$ & 0,100 \\
\hline rét, legelö elszórt fákkal és bokrokkal & $\mathrm{n}_{4}$ & $0,025-0,035$ & 0,030 \\
\hline kert, gyümölcsös & $\mathrm{n}_{5}$ & $0,035-0,070$ & 0,050 \\
\hline szántó & $\mathrm{n}_{6}$ & $0,035-0,070$ & 0,050 \\
\hline mesterséges felszín & $\mathrm{n}_{7}$ & $0,030-0,050$ & 0,040 \\
\hline
\end{tabular}

\subsubsection{Az invazív gyalogakác hatása a növényzeti érdességre}

A gyalogakác növényzetsürüség-növekedésben játszott szerepének meghatározására Warmink (2007) fénykép alapú módszerét alkalmaztam (Parallel Photographic Method), amellyel meghatározható egy adott térfogaton belül a növényzet által elfoglalt terület aránya a folyásiránnyal szembeni felületen. A módszer lényege, hogy egy adott területü $(3 \times 2 \mathrm{~m})$ fehér háttér előtt fényképsorozatot ( $18 \mathrm{db}$ ) készítünk a növényzetről (10a. ábra), így a növényzet sötét területei jól elkülönülnek a világos háttér előtt (10b. ábra). A fényképeket fekete-fehér képekké alakítottam $(10 c$. ábra), ahol a fekete képpontok reprezentálják a növényzetet. Így kiszámítható a fehér háttér előtt a növényzet által elfoglalt terület aránya, amelyet GIMP 2.8 képszerkesztő program segítségével végeztem el. Ezeket az értékeket a következő egyenletbe beillesztve (Warmink 2007) kiszámítható az adott helyszínen a növényzet sürüsége:

$$
D v_{P P}=-\frac{1}{L} * \ln \left(1-A_{t o t}\right)
$$


ahol $D v_{P P}$ a növényzet sürüsége (0 és 1 közötti érték), $L$ a ponyva hossza $(3 \mathrm{~m}), A_{\text {tot }}$ pedig a növényzet által reprezentált fekete képpontok aránya.

Ezt a növényzetsürüség számítást elvégeztem a jelenlegi állapotokra (2017/2018 tele) 15 ponton Szegedtöl északra (4. ábra). A fényképeket 3 felszínborítási kategóriában készítettem: ültetett erdőkben, ártéri erdőkben és olyan művelés alól kivett szántókon, felhagyott réteken és legelőkön, ahol a gyalogakác erőteljes terjedésnek indult. A helyszíneket úgy jelöltem ki, hogy a lefotózott növényzet jól reprezentálja az adott felszínborítási foltot. A fényképeket téli időszakban készítettem, amikor a növényzeten nem volt levélzet.

Ahhoz, hogy kiszámítsam, milyen mértékben járul hozzá a gyalogakác maga a növényzet érdességéhez, a képekről letörtöltem a gyalogakácot (10d. ábra), majd a fenti egyenleltet felhasználva ismét kiszámítottam a növényzet sürüségét.
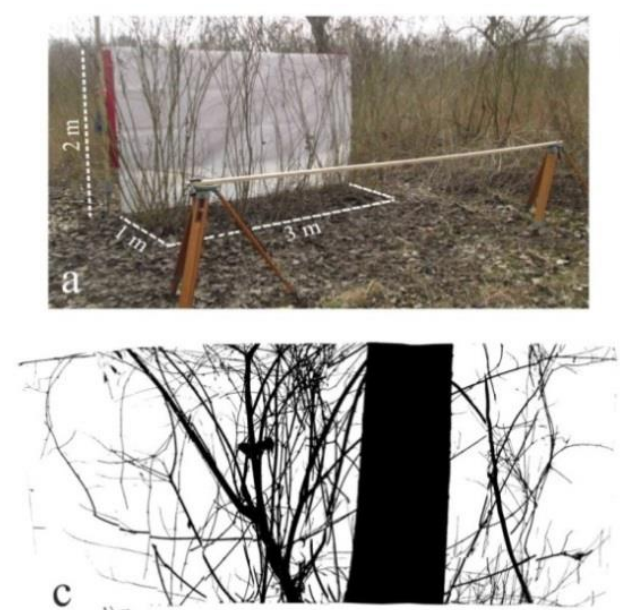

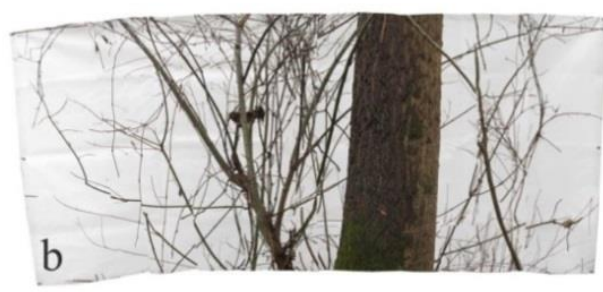

d

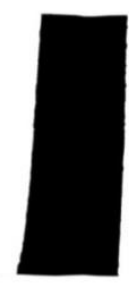

10. ábra. A növényzet fotózása terepen (a), egy növényzetröl készült fénykép fehér háttér elött (b), fekete-fehér képekké átalakitott fénykép, amelyen jól elkülönül a növényzet és a világos háttér (c), és ugyanaz a fotó gyalogakác nélkül (d)

A fényképek alapján számított növényzetsűrüségi értékeket felhasználva a Petryk és Bosmajian (1975) által meghatározott egyenlet segítségével kiszámítottam a 2017. évi állapotokra a növényzeti érdességet (n):

$$
n=n_{0} \sqrt{1+\left(\frac{C_{*} \sum A i}{2 g A L}\right)\left(\frac{1}{n_{0}}\right)^{2} R^{4 / 3}}
$$

ahol $n_{0}$ egy a felszín anyagát jelölő $n$ alapérték, $C *$ a növényzet áramlással szemben súrlódási együtthatója, $\sum A i$ a növényzet vertikális területe $\left(\mathrm{m}^{2}\right)$, amely akadályozza a vízáramlást, $g$ a gravitációs állandó, $A$ az áramlás keresztmetszeti területe $\left(\mathrm{m}^{2}\right), \mathrm{L}$ a vizsgált meder (esetemben hullámtér) szakasz hossza, és $R$ a hidraulikus sugár. A $C * \sum A i / A L$ együttesen a növényzet sürüségét fejezi ki egy adott keresztmetszetben.

A felszín növényzeti érdességét ezután kiszámítottam az alkalmazott hullámtéri területegységeken belül, így minden egységen belül összevethetővé válik a felhalmozódott hordalék vastagsága és a felszín érdessége.

A terepi fotózás és a fényképek feldolgozása során számos hibalehetőség merült fel, amit igyekeztem a lehető legjobban kiküszöbölni. A legnagyobb problémát az jelentette, hogy a fényképek készítésekor a nem függőleges törzsek más-más szögböl fotózva nem ugyanúgy néznek ki a fényképen. Ezen kívül a fekete és fehér pixelek arányát befolyásolta az erőteljes napsütés és a fák árnyéka, illetve a téli időszakban a fák ágain felhalmozódó hó is módosíthatja az eredményeket. Ezek miatt a fényképeket utólagosan korrigálnom kellett. 


\section{Eredmények}

A kutatási eredményeim bemutatását a 19. századi árvízvédelmi töltések kiépítése óta felhalmozódott hordalék vastagságának és térfogatának jellemzőivel kezdem, illetve annak térbeli sajátosságait mutatom be a teljes Alsó-Tisza hullámterén. Ezt követően azt elemzem, hogy az árvíz-mentesítési munkálatok óta zajló feltöltődés mennyivel csökkentette az árvizek levonulására szolgáló hullámtéri térfogatot, azaz, milyen mértékben romlott a hullámtér vízszállító-képessége. $\mathrm{Az}$ eredmények bemutatását a hordalék-felhalmozódást a hullámtér teljes szélességében befolyásoló tényezők vizsgálatával folytatom. Végül a feltöltődés kitüntetett formáit, a folyóhátak (vertikális akkumuláció) és az övzátonyok (horizontális akkumuláció) hosszú távú fejlődését, és a formálódásukat befolyásoló legfontosabb tényezőket vizsgálom meg részletesebben.

\subsection{A hullámtér feltöltődésének jellemzői és a folyamatot befolyásoló tényezők}

\subsubsection{A felhalmozódott hordalék mennyisége és térbeli jellemzöi}

A 19. században zajlott árvízvédelmi töltések kiépítése a hordalék felhalmozódásának gyorsulását eredményezte a leszükített hullámtéren. Az aktív és a mentett hullámtéri területek magasságkülönbsége alapján az Alsó-Tisza hullámterén átlagosan 1,2 m vastag hordalék halmozódott fel, amely 90 millió $\mathrm{m}^{3}$ hordaléknak felel meg. Az elmúlt közel 150 évben tehát körülbelül a Tisza 7 évnyi lebegetett hordalékmennyisége halmozódott fel, ugyanis a Tisza Szegednél 12,26 millió $\mathrm{m}^{3}$ mennyiségü lebegtetett hordalékot szállít évente (Bogárdi 1971).

A lerakódott hordalék átlagos vastagsága a Tisza jobb és baloldali oldali hullámterén egyaránt $1,2 \mathrm{~m}$. Ez területegységenként azonban jelentősen eltér, ugyanis a legintenzívebben feltöltődő hullámtéri területeken 2,6 m vastagságú üledék halmozódott fel (11. ábra), míg a legkevésbé feltöltődő egységekben csupán 0,4 m (Függelék).

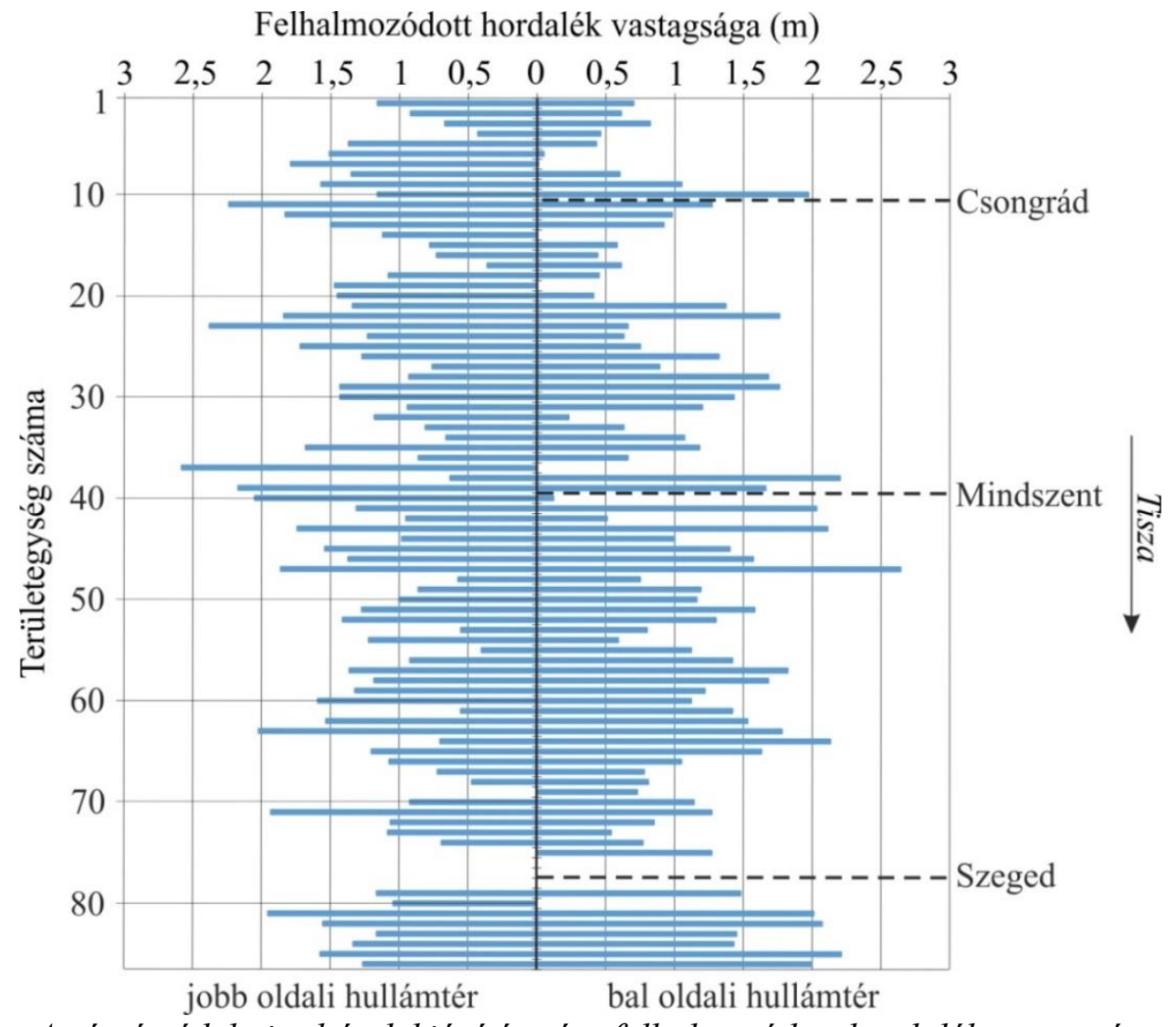

11. ábra. Az árvízvédelmi töltések kiépitése óta felhalmozódott hordalék vastagsága az AlsóTisza hullámterén területegységenként 
A legnagyobb vastagságú felhalmozódást Mindszent térségében mértem, ahol a jobb parton a T37 egységben 2,6 m a felhalmozódás vastagsága, míg a bal oldali T38, 39 és T41 egységeken belül 1,7-2,2 m hordalék rakódott le. Jelentős vastagságú (>2 m) felhalmozódás figyelhető meg a bal oldali hullámtéren a Csongrád térségében lévő T10 területegységben, a hullámtér túloldalán a T11, és a délebbre lévő T23 egységben is. Intenzív feltöltődés jellemzi a Szegedtől északra lévő, Algyő környéki területeket is, ahol a T63 és 64 területegységekben is meghaladja a 2 m-t a hordalék vastagsága. Szegedtől délre, a hullámtér bal oldalán 4 egységben is megfigyelhető $2 \mathrm{~m}$ nél vastagabb hordalék-felhalmozódás.

A legkevésbé feltöltődő területek $(<0,5 \mathrm{~m})$ Csongrádtól északra a hullámtér bal oldalán (T47), illetve a túloldalon egy területegységben (T4) találhatók. Csongrádtól délre egy hosszabb szakaszon (T14-20) jellemző vékony hordalékvastagság a jobb és a bal oldalon egyaránt. Mindszenttől északra a hullámtér bal oldalán a T22 és 32 területegységek közötti szakaszon 4 egységet érint $0,5 \mathrm{~m}$-nél kisebb feltöltődés, de ezeket intenzív hordalék-felhalmozódással jellemezhető területek tagolják. Végül pedig Algyőtől északra a jobb oldali hullámtéren, egy rövidebb szakaszon (T68-69) figyelhető meg kis hordalékvastagság.

A felhalmozódott hordalék térfogatát tekintve a jobb parti egységekben átlagosan 0,35 millió $\mathrm{m}^{3}\left(0,02-1,9\right.$ millió $\left.\mathrm{m}^{3}\right)$, míg a bal oldalon ennek mindegy kétszerese, átlagosan 0,75 millió $\mathrm{m}^{3}$ (0,03-6,2 millió $\left.\mathrm{m}^{3}\right)$ hordalék akkumulálódott. A legnagyobb mennyiségü hordalék $\left(6,2\right.$ millió $\left.\mathrm{m}^{3}\right)$ a T51 területegységben halmozódott fel a hullámtér bal oldalán (12. ábra). Ez a körtvélyesi Holt-Tiszát is magába foglaló hullámtéri öblözetben található, ahol a hullámtér a legszélesebb $(3800 \mathrm{~m})$ az egész Alsó-Tisza mentén. Hasonlóan nagy mennyiségü hordalék sehol máshol nem halmozódott fel a mintaterületen belül. Ugyanakkor 1,5 millió $\mathrm{m}^{3}$-nél több hordalék csupán két területegységben rakódott le a jobb parton (T1-2), míg a bal parton az ilyen mértékü felhalmozódás jóval gyakoribb (T22, T31, T45-T53), amely helyek részben a széles hullámterekhez kapcsolódnak.

A legkisebb térfogatú (mindössze 0,02-0,05 millió $\mathrm{m}^{3}$ ) hordalék a hullámtér bal oldalán halmozódott fel, a Csongrád térségében elhelyezkedő $\mathrm{T} 7$ területegységben. A nagyon kicsi térfogatú $\left(<0,1\right.$ millió $\left.\mathrm{m}^{3}\right)$ felhalmozódással jellemezhető területek csak rövidebb, legfeljebb két területegységet érintő szakaszokat foglal magába és részben egybeesnek a szük hullámtéri területekkel. Ez kifejezetten igaz a hullámtér jobb oldalán, ahol a legkisebb térfogatú hordalék a 100 m-nél szükebb hullámtéri szakaszokon halmozódott fel. A folyó bal oldalán szélesebb szakaszokon (500-600 m) is jellemzőek kis térfogatú felhalmozódások. A mintaterület egészét tekintve Csongrádtól északra a hullámtér jobb oldalán 4 egységben (T4, T6, T11-12) és a bal oldalon 3 egységben (T1, T6-7) halmozódott fel kis térfogatú hordalék. Csongrádtól délre a hullámtér jobb oldalán 3 területegységben (T16-17, T22), és a bal parton szintén 3 egységben (T14, T19-20) halmozódott fel kis mennyiségü hordalék. Ezt követően Mindszent térségében a jobb oldali nagyon szük hullámtéri szakaszokon (T39-40), illetve a bal oldalon 3 területegységben (T36-37, T40) halmozódott fel kis térfogatú hordalék. Folyásirányban lefelé egészen Szegedig csak 3 egységben és csupán a jobb oldali hullámtéren halmozódott fel 0,1 millió $\mathrm{m}^{3}$-nél kevesebb hordalék, a Körtvélyesi holtág öblözetének déli végén (T53), illetve Algyő térségében (T64-65). Szegednél azonban mind a jobb (T73-39) és a bal oldali hullámtéren (T75-80) is egy hosszabb szakaszon megfigyelhető a felhalmozódott hordalék kis mennyisége.

A hordalék vastagságával ellentétben, térfogatát tekintve már lehatárolhatók jellegzetes feltöltődési mintázatot mutató szakaszok, bár ezek határai a jobb és bal oldali hullámtéren eltérők (12. ábra). A jobb oldali hullámtéren a T24 területegységig a felhalmozódott hordalék térfogata átlagosan 0,4 millió $\mathrm{m}^{3}$, majd a T25-T30 egységek között a hordalék térfogata megnő, átlagosan 1 millió $\mathrm{m}^{3}$-re. Ezt követően a T74 területegységig (Szeged) a hordalék mennyisége ismét kevesebb (átlagosan 0,28 millió $\mathrm{m}^{3}$ ), bár van három olyan területegység, ahol a hordalék térfogata meghaladja a 0,5 millió $\mathrm{m}^{3}$-t (T37, T43 és T54). Szegedtől folyásirányban lefelé a hordalék mennyisége fokozatosan nő, átlagosan 0,43 millió $\mathrm{m}^{3}$-re. Míg a jobb oldali hullámtéren a legtöbb területegységben 0,5 millió $\mathrm{m}^{3}$ alatt volt a hordalék 
mennyisége, addig a bal oldalon jóval több szakaszon előfordulnak az ezt meghaladó mennyiségü felhalmozódások. A vizsgált szakasz felvízi részén (T1-T9) a felhalmozódás átlagos mennyisége nagyon kicsi $\left(0,14\right.$ millió $\left.\mathrm{m}^{3}\right)$, jóval alatta marad a szemközti hullámtéri egységek feltöltődésének (átlagosan 0,79 millió $\mathrm{m}^{3}$ ). Majd a T10-T11 egységekben némileg megnő (0,85 millió $\mathrm{m}^{3}$-re), majd fokozatosan csökken a T28 területegységig, így ezen a szakaszon a hordalék térfogata mindössze átlagosan 0,31 millió $\mathrm{m}^{3}$. Ezen a szakaszon egy kivétel van (T22), ahol a hordalék térfogata meghaladja az 1 millió $\mathrm{m}^{3}$-t. A T29 és a T44 egységek között ismét nő a hordalék mennyisége, átlagosan 0,78 millió $\mathrm{m}^{3}$-re, és különösen sok hordalék akkumulálódott a T31 egységben (3 millió $\left.\mathrm{m}^{3}\right)$, ami a hullámtér hirtelen kiszélesedésének eredménye lehet. A T45 és T53 területegységek között a hordalék átlagos térfogata az négyszeresére nő $\left(3,1\right.$ millió $\left.\mathrm{m}^{3}\right)$. Ez a szakasz egybeesik a mártélyi és körtvélyesi holtágakat magába foglaló hullámtéri öblözettel, ahol az Alsó-Tisza hullámtere a legszélesebb (>2000 m). Ezt követően (T54-T86) egészen az országhatárig a hordalék térfogat ismét lecsökken, átlagosan 0,35 millió $\mathrm{m}^{3}$-re.

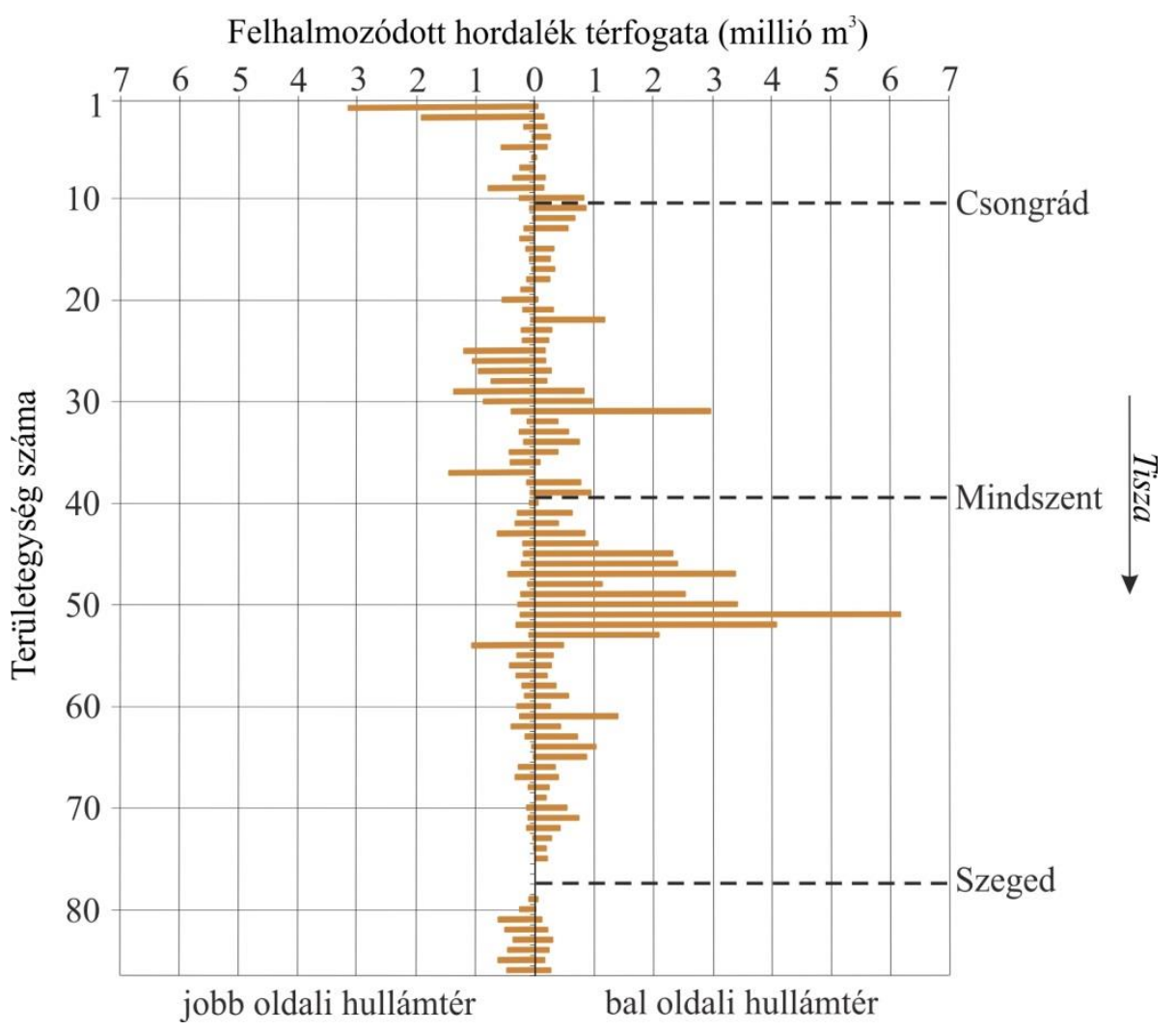

12. ábra. Az árvizvédelmi töltések kiépitése óta felhalmozódott hordalék térfogata az AlsóTisza hullámterén területegységenként

A felhalmozódott hordalék vastagsága és térfogata nem csak területegységenként, de a hullámtér jobb és bal oldalán is eltérô értékeket mutat. A hordalék átlagos vastagsága a két oldalon hasonló, hiszen mind a két oldalon átlagosan 1,2 m vastag hordalék akkumulálódott, illetve a hordalék vastagsága mindkét oldalon 0,4-2,6 m között változik. A különböző vastagságú felhalmozódások gyakorisága azonban eltérő a két oldalon (13a. ábra). A jobb oldali hullámtéren a 0,9-1,6 m közötti hordalék-felhalmozódások fordulnak elő a leggyakrabban, míg a bal oldali hullámtéren a 0,4-0,9 m közöttiek a leggyakoribbak, bár kiugróan sok 1,1-1,19 m és 1,4-1,49 m közötti felhalmozódással jellemezhető területegység is előfordul. A felhalmozódott hordalék térfogata jóval eltéröbb képet mutat (13b. ábra), hiszen mindkét oldalon a 0-0,49 millió $\mathrm{m}^{3}$ közötti felhalmozódások fordulnak elő a leggyakrabban. A hullámér jobb oldalán a 0,1-0,19 millió $\mathrm{m}^{3}$, míg a bal oldalon a 0,2-0,29 milli $\mathrm{m}^{3}$ térfogatú felhalmozódások a leggyakoribbak, majd 0,4-0,59 millió $\mathrm{m}^{3}$-ig az egyek kategóriák 
gyakorisága egyenletesen csökken. A jobb oldalon ezen kívül csak az 1-1,49 millió $\mathrm{m}^{3}$ térfogatú hordalék-felhalmozódások a gyakoribbak, míg a bal oldalon a 0,7-0,89 millió $\mathrm{m}^{3}$, az 1-1,49 millió $\mathrm{m}^{3}$ és a 2-2,99 millió $\mathrm{m}^{3}$-es hordalékmennyiségek is előfordulnak nagyobb gyakorisággal. A hordalék térfogatát tekintve a hullámtér két oldala közötti különbségeket a hullámtér eltérő szélességében látom, hogy míg a holtágak öblözeteinek széles szakaszai elsősorban a bal oldalon jellemzőek (például Osztorai Holt-Tisza, Mártélyi és Körtvélyesi Holt-Tisza), addig a jobb oldali hullámtéren csak egy öblözet (Sulymos) található.

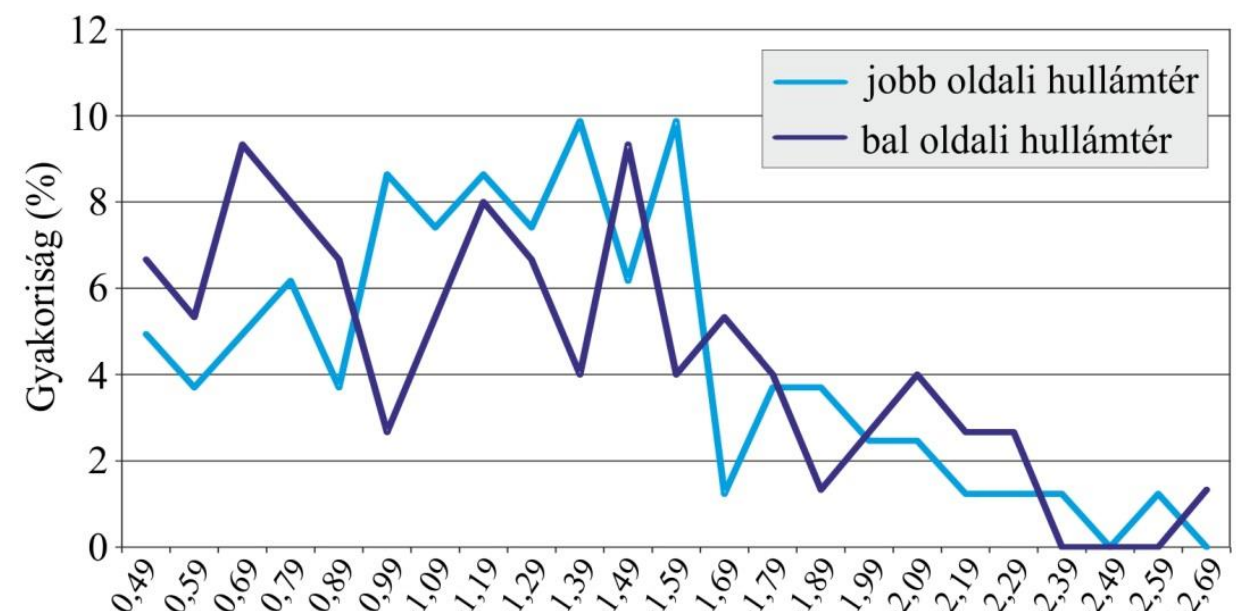

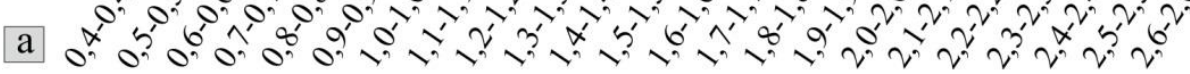

Felhalmozódás vastagsága $(\mathrm{m})$

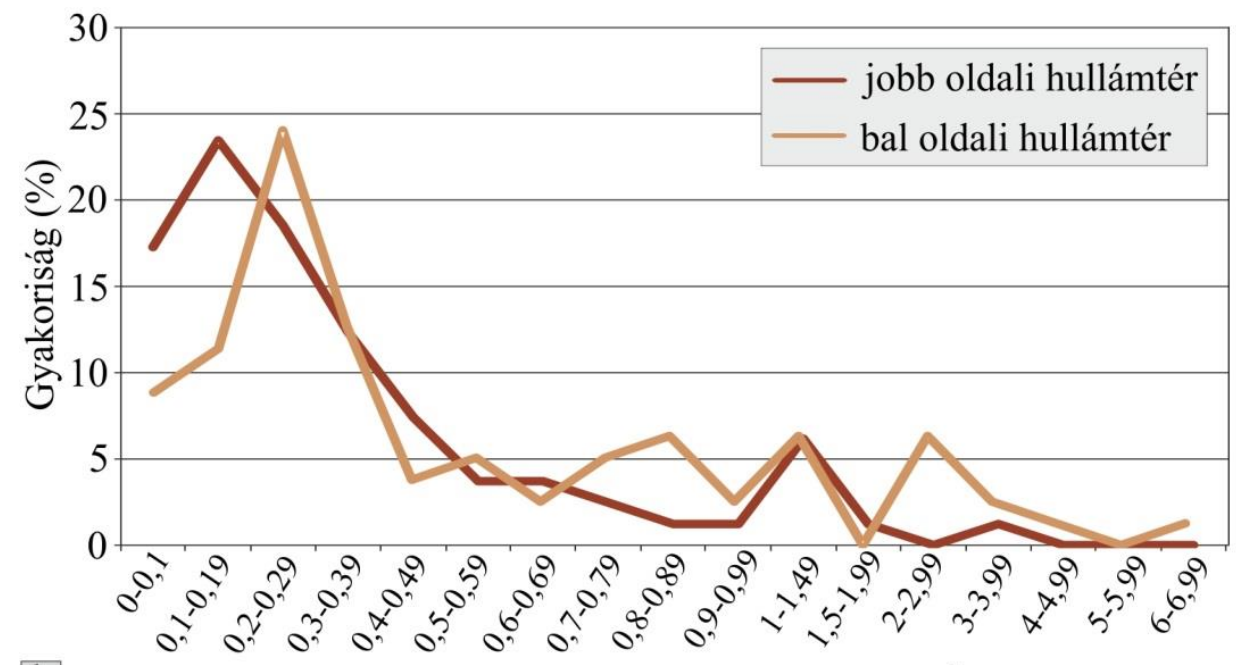

b

Felhalmozódás térfogata (millió $\mathrm{m}^{3}$ )

13. ábra. A különbözö vastagságú (a) és térfogatú (b) hordalék-felhalmozódású területegységek elöfordulási gyakorisága a hullámtér jobb és bal oldalán

Az eddigi eredmények alapján összességében elmondható, hogy az árvízvédelmi töltések kiépítése óta felhalmozódott hordalék vastagsága és térfogata az Alsó-Tisza mentén területegységenként jelentős eltéréseket mutat. Míg a hordalék vastagsága nem mutat egyértelmü folyásiránybeli trendet, addig a hordalék térfogata alapján szakaszok határolhatók le, ahol hasonló mennyiségü hordalék akkumulálódott. Véleményem szerint ez alapján feltételezhető, hogy míg a hordalék térfogata kapcsolatba hozható a hullámtér szélességével, addig a hordalék vastagsága jóval mozaikosabb képet mutat, ami számos helyi tényező hatását feltételezi. A hordalék vastagsága és térfogata nem csak területegységenként, de a hullámtér jobb és bal oldalán is jelentős eltéréseket mutat, amely kapcsolatba hozható az árvízvédelmi töltés aktív folyómedertől való távolságával. Míg a jobb oldali hullámtéren a gát közel fut a folyóhoz, egyes helyeken csupán 20 m a töltés és a folyó közötti távolság, addig a bal oldali 
hullámtéren a gát távolabb fut a medertől, és számos igen széles $(>2000 \mathrm{~m})$ öblözet is előfordul, ami lehetővé teszi a nagyobb mennyiségü hordalék felhalmozódását. Ezért megvizsgáltam a különböző paraméterek hatását a lerakódott hordalék vastagságára és térfogatára.

\subsubsection{A feltöltödést befolyásoló tényezök vizsgálata}

\section{A) Hullámtér-szélesség hatása a felhalmozódott hordalék vastagságára és térfogatára}

Az árvízvédelmi töltések megépítésével az eredeti ártérszélesség a töredékére csökkent, így erősen korlátozottá vált annak a térnek a nagysága, ahol a lebegtetett hordalék árvízkor lerakódhatott. Az Alsó-Tisza mentén sem a hullámtér teljes szélessége, sem a folyó két oldalán húzódó ártér szélessége nem egységes, így a hullámteret számos szükület és tág öblözet jellemzi (14. ábra). Az alsó-tiszai hullámtér átlagos teljes szélessége $1085 \mathrm{~m}$. Míg a jobb oldali hullámtér jóval szükebb (átlagosan $270 \mathrm{~m}$ ) addig a bal oldali hullámtér közel 2,5-szer szélesebb (átlagosan $635 \mathrm{~m}$ ). A jobb parton az árvízvédelmi töltés egyes helyeken csupán $20 \mathrm{~m}$ távolságra van az aktív folyómedertől, ráadásul csupán egy hullámtéri öblözetet hoztak létre ezen az oldalon (Sulymos), mivel az erre az oldalra került nagyobb holtágak (Serházzugi Holt-Tisza, Atkai Holt-Tisza, Gyálai Holt-Tisza) a mentett oldalra kerültek. Ezzel szemben a bal parton a Nagyfai Holt-Tisza kivételével az összes holtág a hullámtéren belül található (Osztorai Holt-Tisza, Mártélyi Holt-Tisza, Körtvélyesi Holt-Tisza).

A mintaterület északi részén, folyásirányban lefelé haladva az első két területegység tág (átlagosan $2790 \mathrm{~m}$ ), majd a 253-

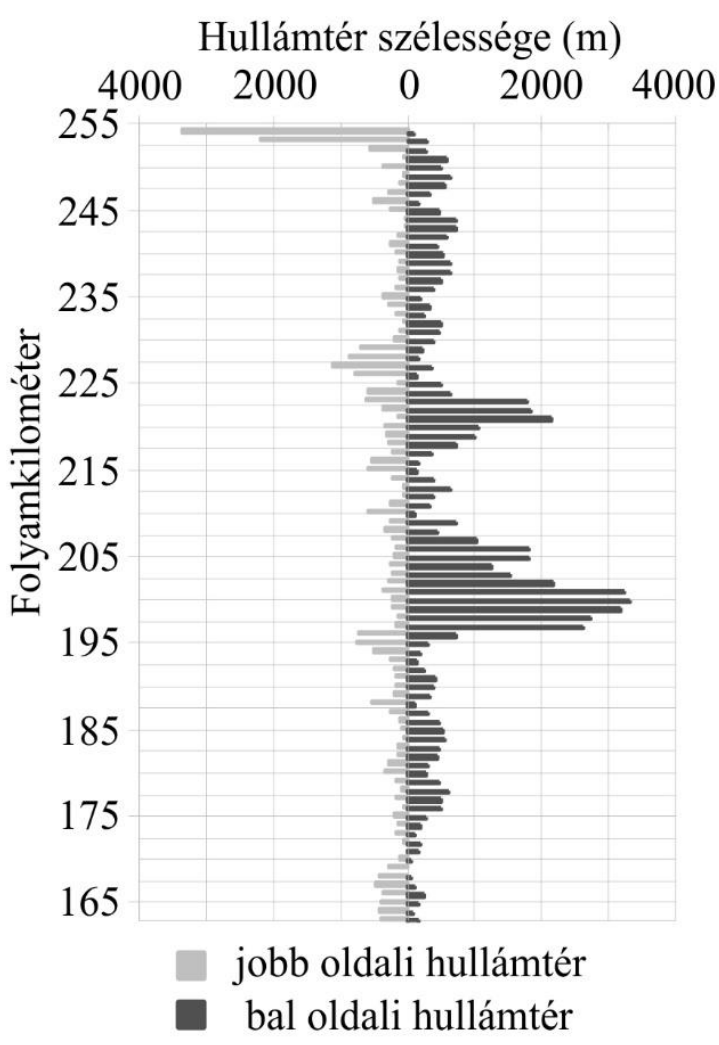

14. ábra. Az Alsó-Tisza menti hullámtér szélességi viszonyai

232 fkm között egységesen szük (átlagosan 805 m), és itt a meder a jobb oldali gát lábához közel fut. Szentes vonalától délre $(232-196 \mathrm{fkm})$ a hullámtér szélessége igen változó (440-3800 m), szük szakaszok és a tág öblözetek váltják egymást. A hullámtér szélessége ezen a szakaszon átlagosan $1655 \mathrm{~m}$. Az öblözetek mindegyike holtágakat foglal magába, ez magyarázza az öblözetek szabálytalan alakját. Emellett a Tisza kanyargóssága is ezen a szakaszon a legnagyobb, hiszen számos szabályozások elötti kanyarulat ma is közel eredeti formájában maradt fenn (pl. Mindszent térségében). A mintaterület alsó szakaszán (196-165fkm) a hullámtér ismét erőteljesen leszükül, szélessége csupán átlagosan 690 m. Az Alsó-Tiszán Szegednél a legszükebb a hullámtér, mindössze $360 \mathrm{~m}$. Szegedtől északra inkább jellemző a jobb oldali hullámtér keskeny volta, míg Szegedtől délre inkább a bal part van közelebb a gátakhoz.

A hullámtér-szélesség hatásának szemléltetésére kiválasztottam két hullámtér-részletet, amelyekben a hullámtér szélessége eltérő (15. ábra). 

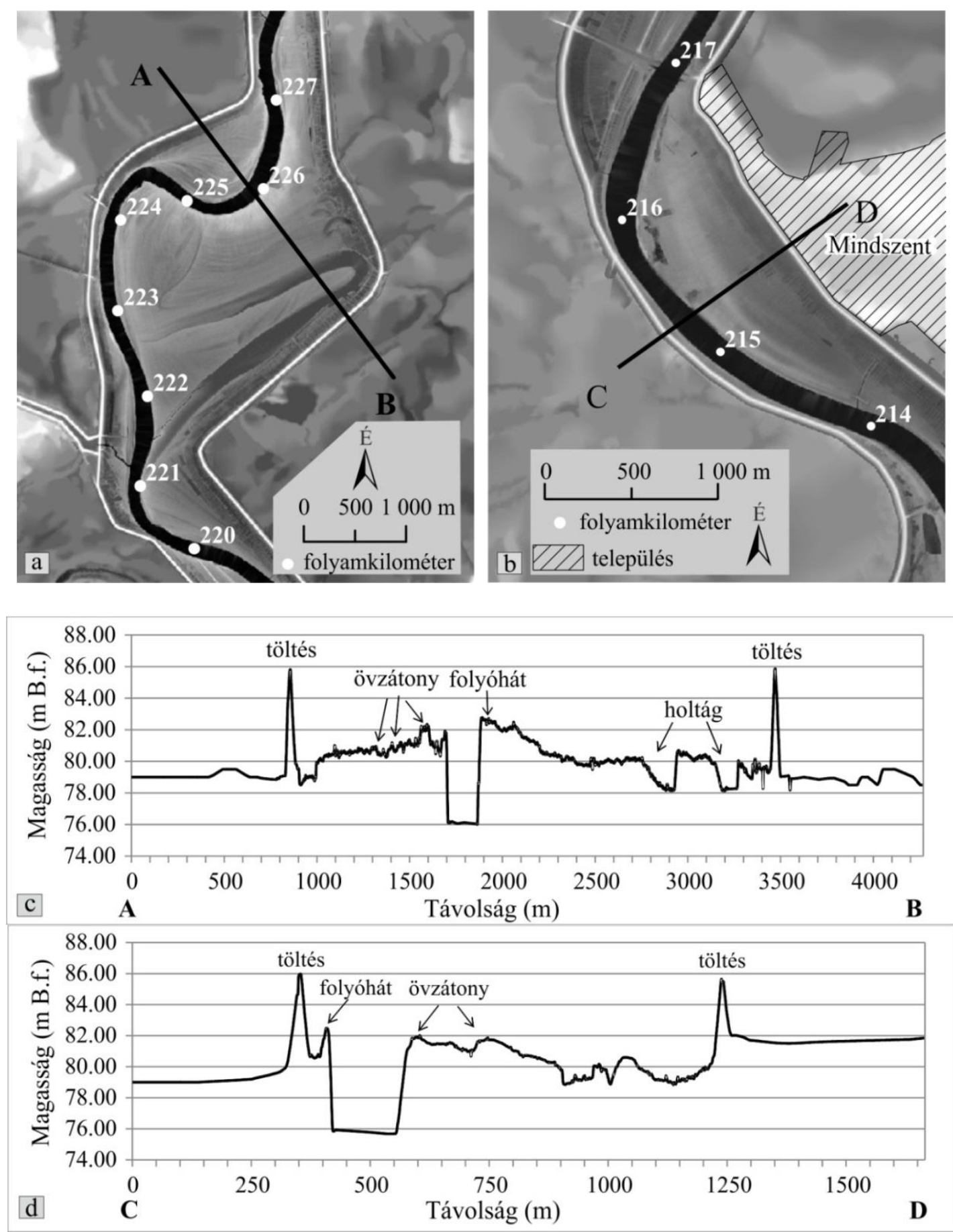

15. ábra. A hullámtér feltöltődése különbözö szélességü hullámtérrészletek példáján, egy széles (a) és egy keskeny hullámtéri (b) területen keresztszelvények alapján (c-d)

Az első keresztmetszet (15a és c. ábra) Mindszenttől északra (226 fkm) vettem fel. Ezen a szakaszon a hullámtér jelentősen kiszélesedik (740 m-ről 2600 m-re), ugyanis ebben az öblözetben található az Osztorai Holt-Tisza. A hullámtér a meder mindkét oldalán széles (jobb: $800 \mathrm{~m}$, bal: $1600 \mathrm{~m}$ ), ennek következtében ezen a szakaszon a folyónak elegendő hely áll rendelkezésre a fejlődésre, így a kanyarulat belső oldalán egy 19 tagú övzátony-sor, a külső íven pedig egy nagyméretü ( $3 \mathrm{~m}$ magas és $250 \mathrm{~m}$ széles) folyóhát formálódott. A felhalmozódott hordalék vastagsága mindkét oldalon az átlag körüli (jobb oldalon 1,2 m; a bal oldalon 1,3 m), azonban a hordalék térfogata jelentősen eltér a két oldalon. A jobb oldali hullámtéren 0,62 millió $\mathrm{m}^{3}$, míg a bal oldalon ennek közel ötszöröse, 2,96 millió $\mathrm{m}^{3}$ hordalék halmozódott fel. Az eltérés okát abban látom, hogy a bal oldali hullámtér kétszer olyan széles, mint a jobb oldali, illetve itt alakult ki a fentebb említett folyóhát is, amely miatt nagyobbnak adódik a hordalék térfogata. 
A második keresztmetszetet Mindszentnél $(215,3 \mathrm{fkm})$ vettem fel (15b és d. ábra). Itt a teljes hullámtér csupán $880 \mathrm{~m}$ széles, és ellentétben az előző mintaterülettel, a két oldal szélessége nagyon eltérő. Míg a bal oldali hullámtér $600 \mathrm{~m}$ széles, addig a jobb oldalon az árvízvédelmi töltés nagyon közel fut a folyóhoz, így a hullámtér szélessége mindössze $50 \mathrm{~m}$. Mindez azt eredményezte, hogy a jobb oldalon jóval nagyobb vastagságú, átlagosan $2,2 \mathrm{~m}$ hordalék halmozódott fel folyóhát formájában, míg a bal oldalon 1,7 m rakódott le, ami 0,5 m-rel kevesebb, a szemben lévő oldal akkumulációjánál, de az átlagosnál kicsit nagyobb. A hordalék térfogata itt is - hasonlóan a fent bemutatott esethez - a szükebb, jobb oldalon kisebb $\left(0,06\right.$ millió $\left.\mathrm{m}^{3}\right)$, míg a tágabb bal oldali hullámtéren ennek közel 15-szöröse (0,94 millió $\left.\mathrm{m}^{3}\right)$.

A két mintaszelvény eredményei alapján feltételeztem, hogy a szükebb hullámtéren vastagabb, de kisebb térfogatú hordalék, míg szélesebb hullámtéren vékonyabb, de nagyobb térfogatú hordalék halmozódik fel.

$\mathrm{Az}$ egyes hullámtéri területegységekben mért hordalékvastagságot és- térfogatot összevetettem az adott területegységben mért átlagos hullámtér szélességgel (16. ábra). A területegységeket 4 csoportra osztottam a hullámtér szélessége és a szélesség folyásirányba $\mathrm{n}$ történő változása alapján, így megkülönböztettem szük (szélesség $\leq 700 \mathrm{~m}$ ), folyásirányban táguló vagy szükülő (szélesség: 700-1000 m) szakaszokat, amelyek általában az ártéri öblözetek kezdetét és végét jelzik, illetve tág (szélesség $\geq 1000 \mathrm{~m}$ ) szakaszokat, amelyek ártéri öblözeteket reprezentálnak.
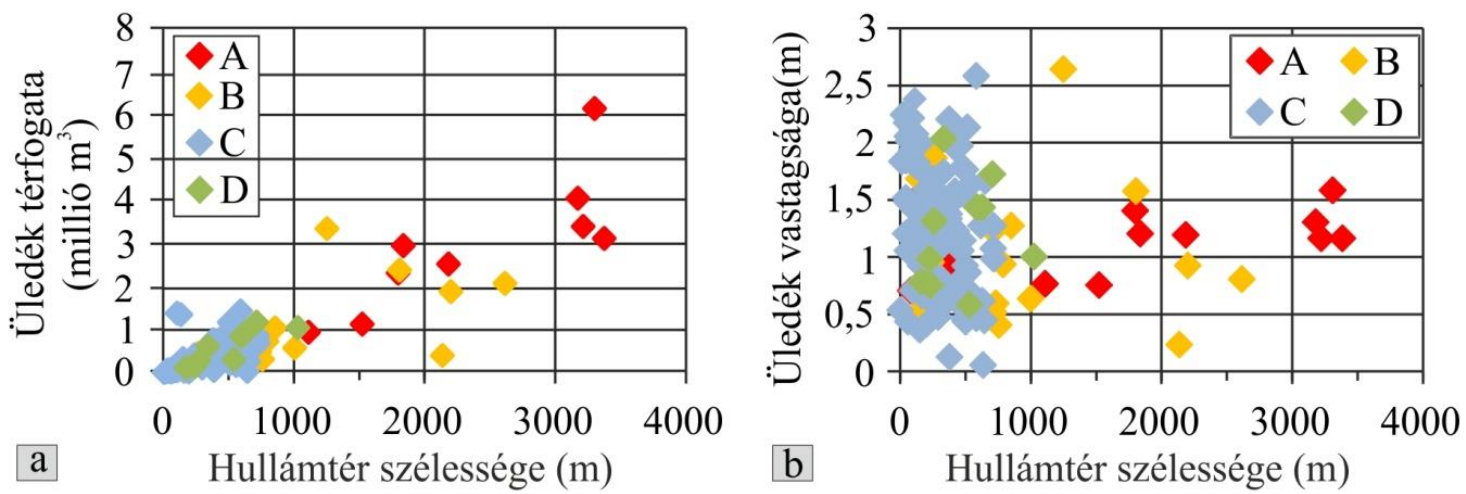

16. ábra. A hullámtér-szélesség és a felhalmozódott hordalék térfogata illetve vastagsága közötti kapcsolat (A: tág szakaszok, B: szükülö szakaszok, C: szük szakaszok, D: táguló szakaszok)

Az eredmények azt mutatják, hogy a felhalmozódott hordalék térfogata és a hullámtér szélessége között egyenes arányosság van $\left(\mathrm{R}^{2}=0,87\right)$, tehát minél szükebb a hullámtér, annál kisebb mennyiségü hordalék rakódik le (16a. ábra). A szük hullámtéri szakaszokon, a felhalmozódás térfogata legfeljebb 1,45 millió $\mathrm{m}^{3}$. A folyásirányban lefelé táguló, de még mindig szük szakaszokon legfeljebb 1,5 millió $\mathrm{m}^{3}$ hordalék halmozódott fel. A tág szakaszokon az elöbbi két csoporthoz képest 4-szeres mennyiségü hordalék halmozódott fel $\left(6,14\right.$ millió $\left.\mathrm{m}^{3}\right)$, míg a folyásirányban szükülő, de még tág hullámtéri területegységekben a felhalmozódás maximális térfogata feleakkora, mint a tág szakaszok esetében $\left(3,4\right.$ millió $\left.\mathrm{m}^{3}\right)$, de még mindig közel kétszerese a szük hullámtéri szakaszokon vagy a táguló szakaszon mértnek. Árvizekkor a hullámtéri öblözetek alvízi ágában az összeszükülő meder a vizet visszaduzzaszthatja, így a mögöttes és szélesebb hullámtéri területeken kialakuló pangó vízből nagyobb mennyiségü hordalék képes kiülepedni, amely növelheti a tág szakaszokon a felhalmozódott hordalék térfogatát.

A felhalmozódott hordalék vastagsága azonban nem mutat ennyire egyértelmü kapcsolatot a hullámtér szélességével (16b. ábra). Mind a négy csoport esetében előfordulnak vékonyabb és vastagabb felhalmozódások is szük és széles hullámtéri szakaszokon egyaránt. Míg a szük és a szükülő hullámtéri szakaszokon 0,4-2,6 méter vastagságú hordalék halmozódott fel, addig a táguló szakaszokon 0,6-2 m, a tág szakaszokon pedig 0,6-1,6 m a hordalék vastagsága. Az, hogy a hordalék vastagsága és a hullámtér szélessége nem mutat egyértelmü kapcsolatot a helyi 
befolyásoló tényezők fontosságát jelzi, illetve azt, hogy az adott helyen kialakuló mederélhez kötődő ártéri forma (folyóhát vagy övzátony) is alapvetően befolyásolhatja a feltöltődés vastagságát.

\section{B) A mellékfolyók hatása a hullámtér feltöltödésére}

A mintaterületen a Hármas-Körös és a Maros torkollik a Tiszába, ami lehetőséget adott arra, hogy a feltöltődésre gyakorolt hatásukat értékeljem. Csupán a torkolatok alatti és feletti 4-5 km hosszú szakaszon vizsgáltam a hatásukat, hiszen a mellékfolyók által szállított hordalék nem a teljes folyószakaszon befolyásolja a hordalék-felhalmozódást. A torkolatok közvetlen közelében jelentősebb lehet a hatásuk, mint távolabb, ugyanis itt jelentkezik a Tisza eséséhez, hordalékhozamához és fajlagos munkavégző-képességéhez képest a legnagyobb hordaléktöménység-változás.

A Hármas-Körös torkolata felett (T8-12) 1-2,2 m vastag a felhalmozódott hordalék vastagsága, míg a torkolattól lefelé (T14-18) mindössze 0,4-1,1 m, ami 0,6-1,1 méterrel kevesebb, mint felvízi irányban (17. ábra). Az üledék térfogatát tekintve is hasonló figyelhető meg, hiszen a torkolattól felfelé átlagosan 0,42 millió $\mathrm{m}^{3}$-nyi hordalék halmozódott fel területegységenként, míg lefelé ennek mindössze a fele, átlagosan 0,21 millió $\mathrm{m}^{3}$.

A Maros torkolata feletti szakaszon (T70-74) átlagosan 1,0 m (0,5-1,9 m) az üledék vastagsága (17. ábra), míg a torkolat alatt (T76-82) ennek közel 1,5-szerese halmozódott fel, az üledék vastagsága itt átlagosan 1,6 m (1-2,1 m). Az üledék térfogatában viszont nem tapasztalható ez a növekedés. Míg a torkolat felett területegységenként átlagosan 0,26 millió $\mathrm{m}^{3}$ az üledék térfogata, addig a torkolat alatt ennek mindössze fele, 0,13 millió $\mathrm{m}^{3}$ hordalék akkumulálódott területegységenként. Ez az eltérés azonban származhat a mérés hibájából, hiszen Szeged területén belül a mentett ártéri területek erőteljes beépítettsége és megmagasítása miatt a hullámtéren felhalmozódott hordalék vastagságát, így térfogatát sem lehetett pontosan meghatározni.

A Körösök és Maros feltöltődésre gyakorolt hatása közötti különbséget okozhatja az, hogy a két folyó eltérő hidrológiai tulajdonságokkal és eséssel rendelkezik, illetve különbözik az általuk lebegtetve szállított hordalék mennyisége is. A Maros nagy eséssel (7-9 cm; Kiss et al. 2011) torkollik a nála jóval kisebb esésű Tiszába $(2 \mathrm{~cm} / \mathrm{km})$. Emellett nagy mennyiségü lebegtetett hordalékot is szállít, évente 4,6 millió $\mathrm{m}^{3}$-nyit (Bogárdi 1971), amelynek nagy része a hirtelen eséscsökkenés következtében lerakódik a Tisza hullámterén a torkolattól lefelé alvízi irányban, azonban a torkolattól egy kissé távolabb. A szük hullámtér hatása is jelentős lehet, hiszen a torkolat feletti szakaszon $840 \mathrm{~m}$ széles hullámtér a torkolat alatt $470 \mathrm{~m}$-re szükül. A szük hullámtér és a Maros nagy esése miatt megnövekedő fajlagos munkavégző képesség miatt a hordalék felhalmozódása helyett annak elszállítása jellemző a torkolattól számított $3 \mathrm{~km}$-en belül annak ellenére, hogy a Maros nagy mennyiségü hordalékkal járul hozzá a Tisza hordalékhozamához. A Szeged alatti szakaszon, a T81 területegységtöl azonban a hullámtér ismét kitágul (átlagosan 750 m-re), így a vízáramlás kissé lelassul és megindul a hordalék intenzívebb akkumulációja, amely a T81 és T82 területegységekben a legintenzívebb. Ezzel ellentétben a Körös esése $(0,5-3,3 \mathrm{~cm} / \mathrm{km})$ a Tiszáéhoz nagyon hasonló, így a vízsebesség csökkenése jóval kisebb mértékü, mint ami a Maros esetében tapasztalható. Emellett a Körös tizedannyi lebegtetett hordalékot szállít, mint a Maros, évente mindössze 0,4 millió $\mathrm{m}^{3}$-t (Bogárdi 1971) amihez hozzájárulhatnak a torkolattól nem nagy távolságra megépített duzzasztók (Bökényi-duzzasztó 5,5 km-re, illetve a Békésszentandrási-duzzasztó $48 \mathrm{~km}$-re), amelyek a hordalék nagy részét felfogják. Az, hogy a Körösök által szállított hordalék nem növeli a torkolat alatti szakaszon akkumulálódott hordalék mennyiségét, összefüggésbe hozható azzal, hogy a két folyó vízhozamának egyesülésével a Körösök mérsékeltebb hordalékhozama miatt a víz viszonylagos hordalékszegénysége párosul a megnövekedett vízhozam miatti munkavégző képesség nevekedésével, ami a hordalékszállítás felé tolhatja el a szakasz hordalékegyensúlyát az akkumuláció irányából. Ez a hatás a T18 területegységig érvényesül, ahol a hullámtér jobb oldalán az akkumuláció ismét intenzívebbé válik, de ez véleményem szerint már nem a HármasKörös hatásának eredménye. 


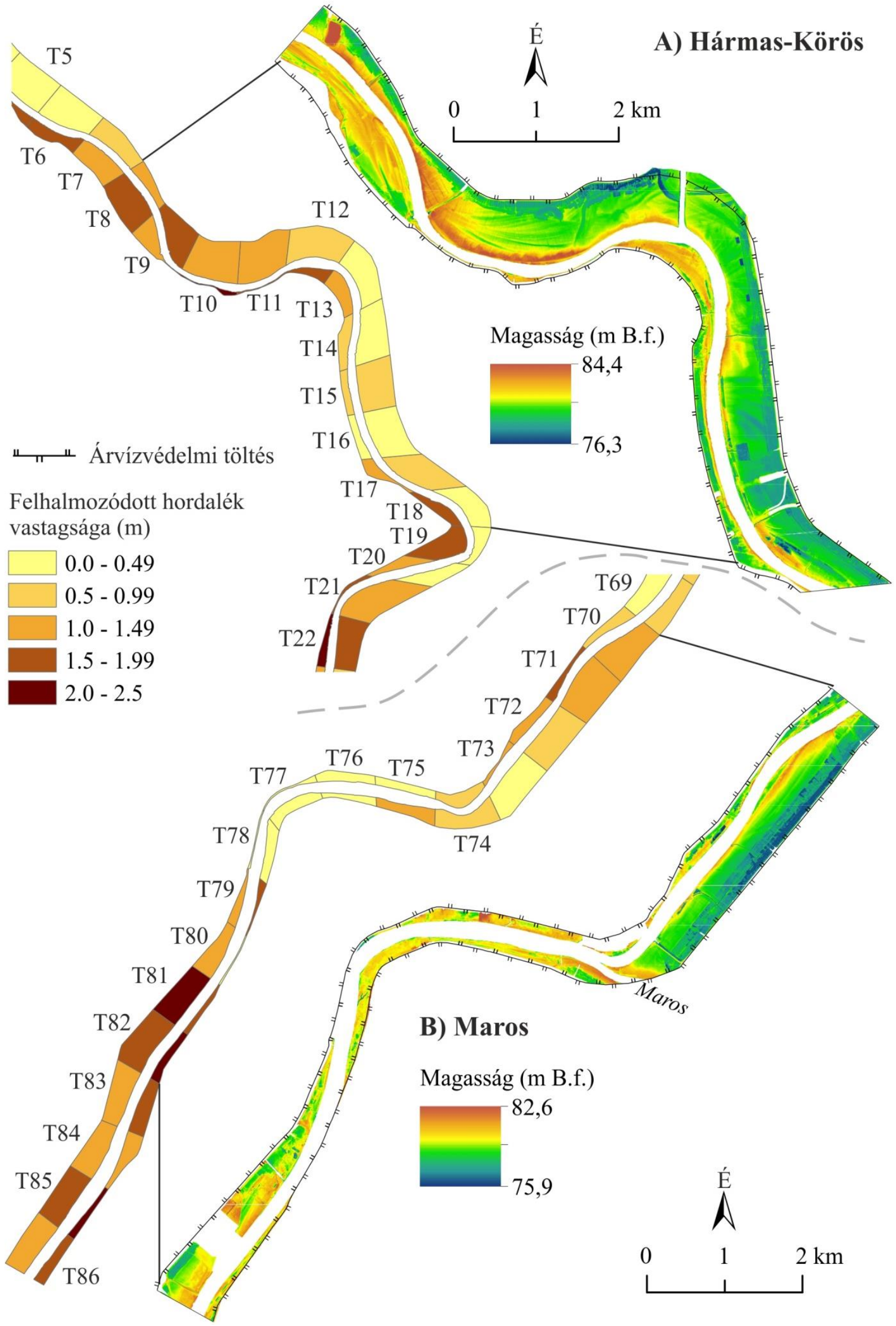

17. ábra. A Hármas-Körös és a Maros torkolata feletti és alatti Tisza-hullámtér domborzata LiDAR felérés alapján, valamint az egyes területegységekben mért hordalékvastagságok térbeli mintázata 


\section{C) Felszínboritás-változás és a növényzet hatása a hullámtér feltöltödésére}

Az Alsó-Tisza hullámterének felszínborítása jelentősen megváltozott a 18. század vége óta (18-19. ábrák). A felszínborítás változásait a teljes mintaterület adatai alapján elemzem, de a változásokat nem lehet a teljes mintaterületre vonatkozóan térképen ábrázolni, hiszen a hullámtér keskeny, a foltok pedig aprók. Ezért a térképi bemutatáshoz két hullámtéri területet választottam, egy szükebb szakaszt Csongrádnál, illetve egy tágabb hullámtéri öblözetet, amely a Mártélyi-holtágat övezi (19. ábra). Eredményeimet az árvízvédelmi töltésekkel határolt jelenlegi hullámtérre vonatkozóan mutatom be.

Az I. katonai felmérés (1784) a folyószabályozások és árvízvédelmi töltések megépítése előtti állapotokat ábrázolja, így a mintaterület legnagyobb részét (83\%) állandóan vagy az év jelentős részében vízborítás alatt lévő területek borították. Az erdők aránya a teljes területen mindössze $6 \%$ volt, kisebb-nagyobb erdőfoltok legfeljebb a meder menti keskeny sávban fordultak elö, amely a környezeténél magasabb lehetett. Szintén a magasabb térszíneken, amelyek csak ritkábban kerültek elöntés alá, jellemzőek voltak a rétek és legelök (7\%), illetve a szántóföldi müvelés is (4\%). A nagykiterjedésű vizenyős területek mind Csongrád, mind Mártély térségében domináltak, de a partokat kísérő galériaerdő foltok is megjelentek mindkét területen, de csak a meder túloldalán, távol a településektől. A mártélyi mintaterületen látványosan megjelennek a szántók és a gyepek a magasabb, árvizekkel kevésbé veszélyeztetett helyeken.

A szabályozások során az Alsó-Tisza mentén 10 kanyarulatot vágtak le, amelyek közül a II. katonai felmérés idejére (1861-1864) hat már elkészült, viszont a térképezés a Sulymos I.-II., a mártélyi és a nagyfai kanyarulatok levágását még nem ábrázolta, ezért az ekkora már teljes hosszában megépült árvízvédelmi töltésrendszer futásvonala még nem teljesen a mait követte. A munkálatok megkezdése miatt a vizenyős területek kiterjedése jelentősen lecsökkent (20\%-ra), helyüket rétek és legelők (64\%) foglalták el. Az erdők kiterjedése változatlan maradt (6\%), és továbbra is csak a part menti magasabb térszíneken fordultak elö. A hosszabb vízborítás nélküli időszakok lehetővé tették a szántóföldi müvelés megkezdését is, azonban a szántóterületek aránya még mindig nagyon alacsony volt (6\%). A változások jól nyomon követhetők a mártélyi öblözetben is, ahol látványosan megjelenik a vizenyős területek csökkenése, amelyeket felváltottak a rétek és a legelők. Ezzel szemben a csongrádi mintaterületen továbbra is nagy volt a vízborítás alatt lévő területek aránya, a rétek és legelők csak a Körösök torkolatát és a Tiszát szegélyező területeken fordultak elö.

A III. katonai felmérés idejére (1881-1884) a mártélyi kanyarulat kivételével az összes alsó-tiszai átvágást megvalósították, a mártélyi szürflexiós kanyart közvetlenül a térképezést követő években (1889-1892 között) vágták át (Pálfai 2001). A térképezés idejére a mocsaras területek szinte teljesen megszüntek (4\%), kisebb foltokban a medertől távolabb lévő mélyebb térszíneken fordultak elő. A rétek és legelők aránya tovább nőtt (összesen 76\%), amelyek közel fele $(40 \%)$ beerdősülésnek indult. A kizárólag erdővel borított területek aránya mérsékelten nőtt (15\%-ra), amelyek továbbra is elsősorban a meder közeli sávban fordultak elö, nagyobb foltokat pedig azok a területek alkottak, amelyek egykor rétek és legelők voltak, de ekkorra már teljesen beerdősültek. A szántóterületek aránya lecsökkent (2\%-ra), kisebb foltokban a hullámtéri öblözetek magasabb térszínein fordultak elö. Ez jól látszik a mártélyi mintaterületen, ahol csupán a meder bal oldalán, a magasabb térszíneken folyt kisebb foltokban a szántóföldi müvelés. Emellett látványosan megjelenik a part menti sávban a rétek és legelők beerdősülése, a galériaerdők kialakulása. Csongrád környékén a változások később jelentkeztek, ugyanis itt csak ekkor váltották fel szinte teljes mértékben a vizenyős területeket a rétek és a legelők.

Az 1980-as évekre jelentősen megváltozott az Alsó-Tisza hullámterének felszínborítása. Elkezdődött a nyárerdők telepítése, a rétek és legelők helyét beerdősítették, így arányuk ekkor már csupán $20 \%$ volt. Az erdőtelepítések hatására az erdők kiterjedése a sokszorosára nőtt (61\%-ra). Ezen kívül a szántóterületek aránya is megnőtt (14\%), és elsősorban a tágabb 
hullámtéri szakaszokon a településekről könnyen megközelíthető helyeken fordultak elő. Megkezdődött a települések közvetlen közelében a hullámtér turisztikai célú használata is, elsősorban Csongrád, Mártély és Szeged térségében épült be a hullámtér. A mesterséges felszínek aránya a hullámtér teljes területéhez képest azonban rendkívül alacsony volt (mindössze 1\%). Mind a két területen látványosan megjelenik a szántóterületek arányának növekedése. Csongrádnál elsősorban a településhez közel elhelyezkedő hullámtéri szakaszokon fordultak elő, míg Mártély térségében pedig a medertől távolabb, az öblözet középső területeit foglalták el. Az erdő arányát tekintve a csongrádi területen a változások ebben az időszakban is kissé lemaradtak, hiszen a csupán erdővel borított területek jóval kisebb arányban fordultak elö, mint a mártélyi öblözetben, ellenben nagy volt a beerdősülésnek indult területek aránya.

Napjainkban az Alsó-Tisza hullámterének 73\%-át borítja ültetett és ártéri erdő. Az egykori szántóföldi területek és gyepek egy részét nem erdősítették be, hanem az extenzív erdősítési időszak után is eredeti funkciójukban használták, azonban ezek nagy részét az utóbbi évtizedben felhagyták. A parlaggá vált területek ma már kizárólag gyalogakáccal borított felszínek, arányuk 10\%, míg a nem fertőzött gyepek aránya $11 \%$, a nem fertőzött szántóföldeké pedig mindössze $2 \%$. A csongrádi és a mártélyi mintaterületen is jól nyomon követhető a szántóföldek arányának erőteljes csökkenése, amelyek jelentős részét ma már a kizárólag gyalogakáccal borított felszínek váltották fel, habár ezen területek aránya a csongrádi szakaszon jóval kisebb, mint Mártély térségében.

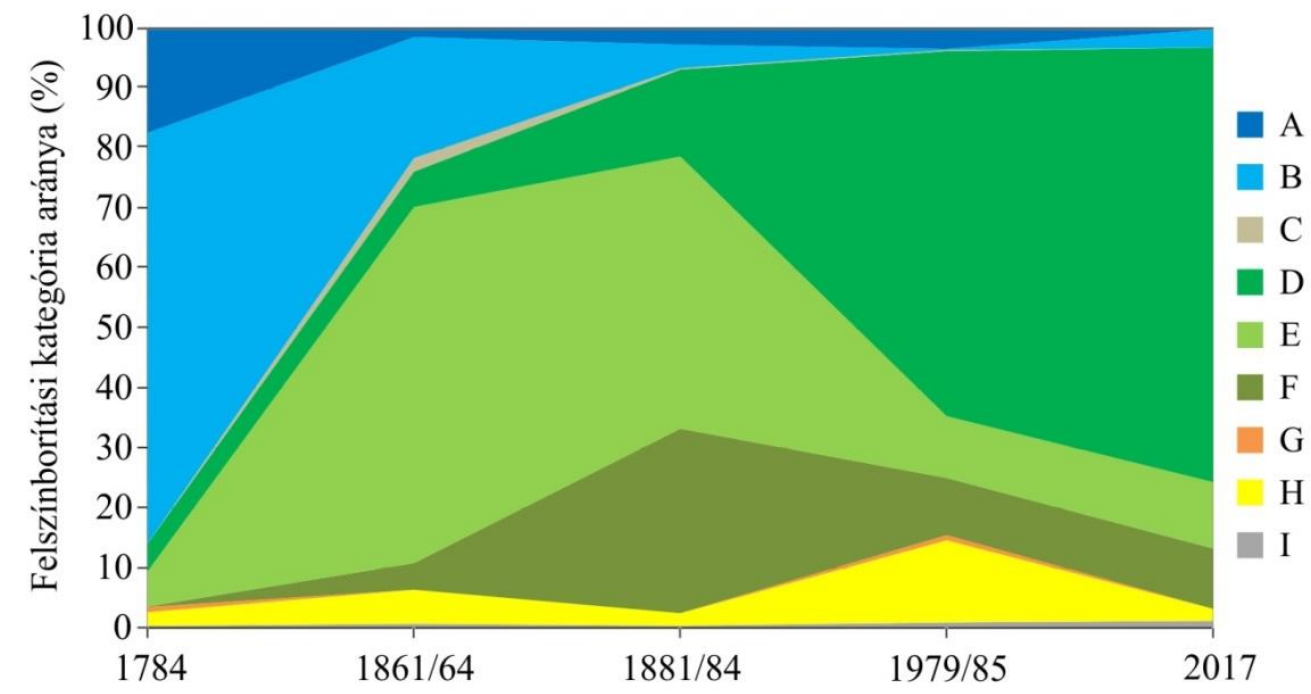

18. ábra. A különbözö felszínboritási kategóriák területi arányának változása a 18. század vége óta az Alsó-Tiszán (A: vízfelszín, B: vizenyős terület, $C$ : csupasz felszín, D: erdö, E: rét, legelö, F: rét, legelő elszórt bokrokkal és fákkal, G: kert, gyümölcsös, H: szántó, I: mesterséges felszín) 

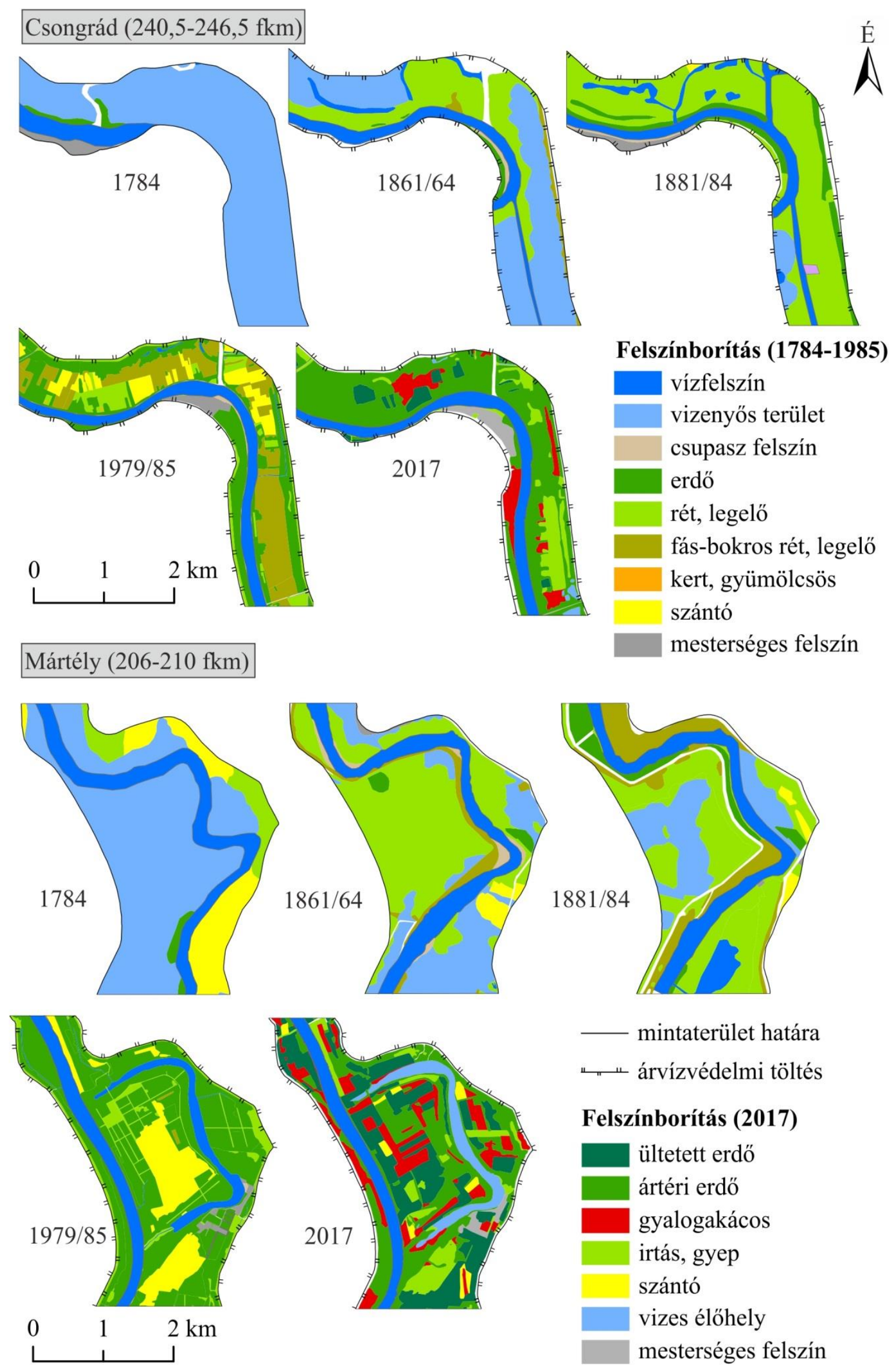

— mintaterület határa

ఒ"— árvízvédelmi töltés

Felszínborítás (2017)

\begin{tabular}{|l}
\hline ültetett erdő \\
ártéri erdő \\
gyalogakácos \\
irtás, gyep \\
szántó \\
vizes élőhely \\
mesterséges felszín
\end{tabular}

19. ábra. A felszínboritás változása a 18. század vége óta az Alsó-Tisza csongrádi és mártélyi szakaszának példája alapján (Mártélynál a fehér vonalak az árvízvédelmi töltés korábbi futásvonalát jelölik) 
Az invazív fajok, és az általam is vizsgált gyalogakác azonban nem csak a parlaggá vált szántókon és legelőkön, de az ártéri és ültetett erdőkben is jelen vannak. A gyalogakác aránya ezekben a felszínborítási kategóriákban meglehetősen változó, így a növényzet sürüsége $\left(\boldsymbol{D} \boldsymbol{v}_{\boldsymbol{P P}}\right)$ is eltérö (20. és 21. ábra).

Az Alsó-Tisza mentén a hullámtér 47\%-a közel természetes erdő. Az öreg fák árnyékoló hatása miatt a gyalogakác szerepe a legkisebb az ártéri erdőkben, így ezekben az erdőfoltokban átlagosan csupán 3\%-kal növeli a növényzetsürüséget, bár ez változhat a fényviszonyok és a bolygatás függvényében (0-10\%). Ezekben a természetes ártéri erdőkben a fénykép alapú módszerrel számítottak alapján a jelenlegi növényzetsürüség 0,13 (min: 0,06, max: 0,22), míg gyalogakác irtásával átlagosan 0,12 lenne.

A mintaterület felszínének 25\%-a ültetett nyaras, amelyek különböző korú faállományokból állnak. Általában az erdőmüvelés első éveiben még kiirtják az ültetvény aljnövényzetét, de később, amikor a fák már a gyalogakác szintje (3-4 m) fölé magasodnak, akkor már nem. Mivel az ültetett erdők lombkoronája kevésbé zárt, ezért jóval több napfényt engednek át, így az idősebb ültetvények - a gondozás elmaradásának függvényében - jelentős mértékben fertőződhetnek invazív fajokkal. A mintaterületen a gyalogakác átlagosan $23 \%$-kal növeli az ültetett nyarasok sürüségét, hiszen ezen erdőknek a jelenlegi növényzet sürüsége felméréseim alapján átlagosan 0,10 (min: 0,07, max: 0,15), de ha a gyalogakácot kiirtanák, akkor értéke átlagosan 0,08-ra csökkenthetö lenne.

Az Alsó-Tiszán a gyalogakác azokon a területeken növeli leginkább a növényzet sürüségét, amelyek egykoron rétek, legelők vagy szántók voltak, és amelyek napjainkra parlaggá váltak. A parlagosodás a 2006-os árvizeket követően gyorsult fel, amikor 6-8 méteres vízoszlop borította a tetőzés csúcsán 1 hétig az árteret, és maga az árvíz is 104 napig tartott (Kiss 2014). Ez a vízállás részben elpusztította a mezőgazdasági kultúrákat, részben pedig a természetes vegetáció aljnövényzetét is. Ráadásul az árvizes időszak 1998-ban kezdődött és 2006-ig tartott, így a gazdák feladták ezen területek megmüvelését az évről évre visszatérö árvizek okozta veszteség miatt. Ezeken a parcellákon a gyalogakác 100\%-os sürüségnövekedést is eredményezhet, de a kevésbé fertőzött területeken is átlagosan $76 \%$-kal (minimum 50\%) növeli a növényzeti sürüséget. A gyalogakác jelenléte miatt ezen parlagokon a növényzeti sürüség jelenleg átlagosan 0,12 (min: 0,09, max: 0,16).Ugyanakkor, ha a gyalogakácot kiirtanák, a növényzet sürüsége 0,03 lenne.

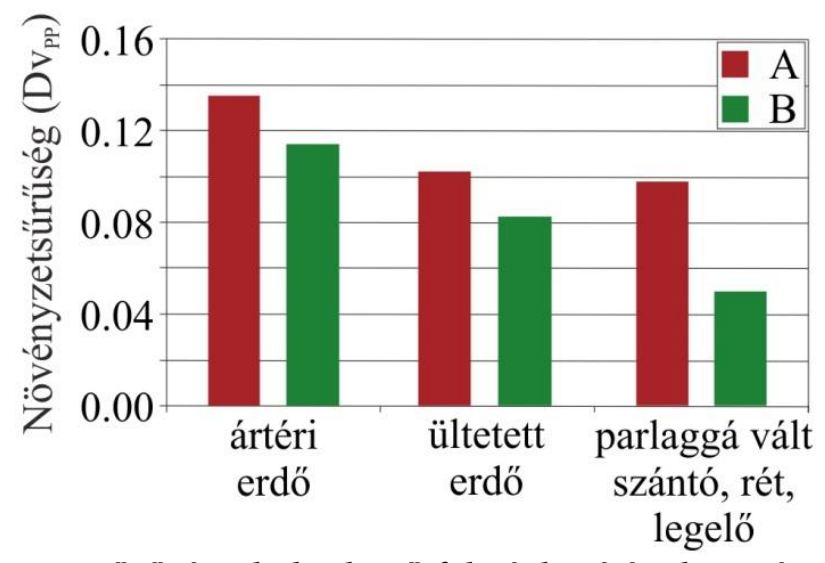

20. ábra. A növényzet sürüsége különbözö felszínboritási kategóriákban a jelenlegi, gyalogakáccal fertözött állapotban (A), illetve egy gyalogakác nélküli állapotot feltételezve

(B) 
A) Ártéri erdő
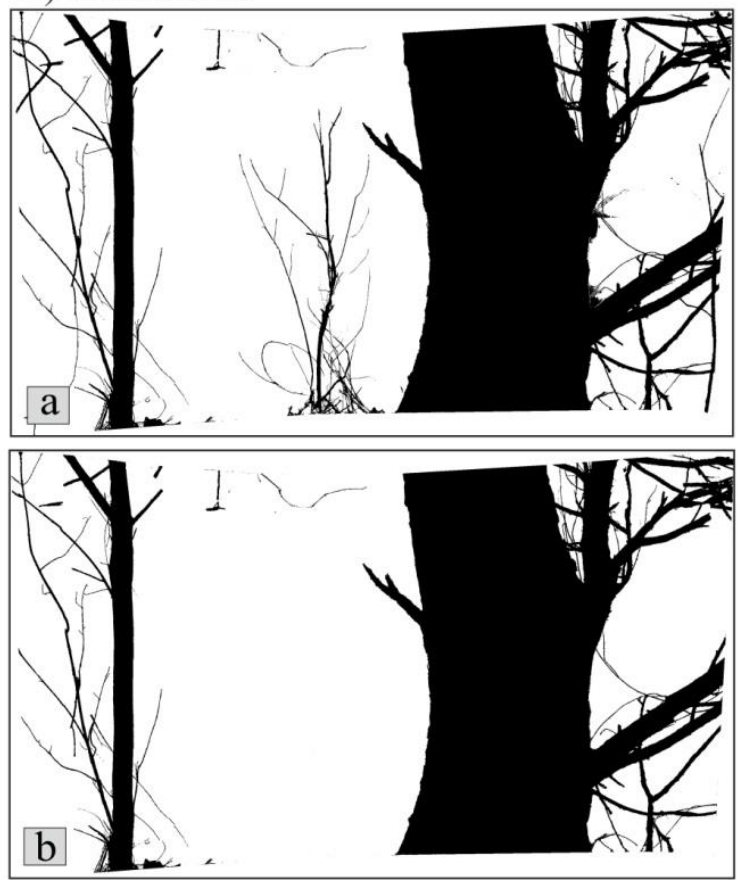

B) Ültetett nyárerdő
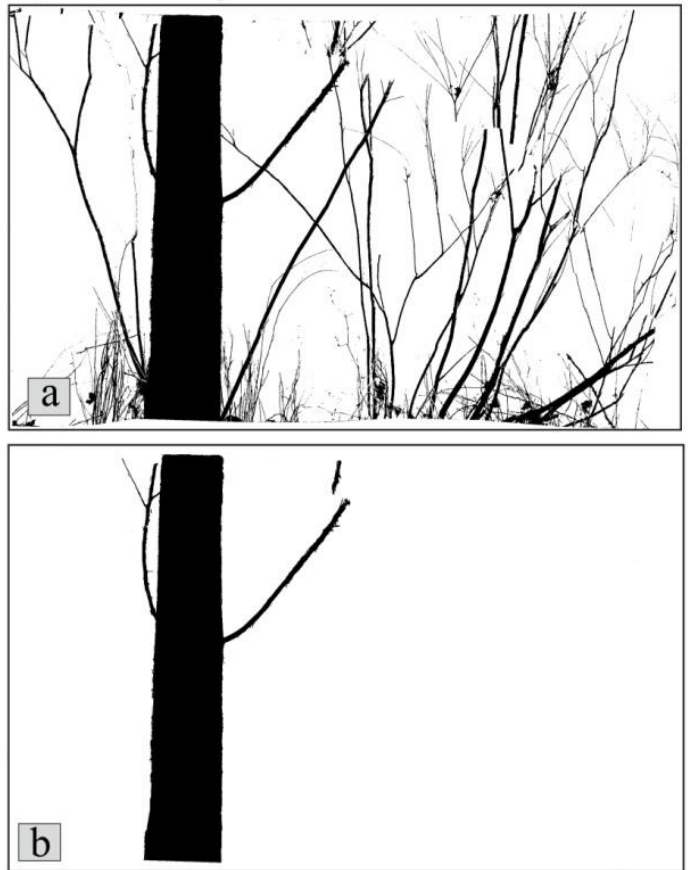

C) Gyalogakácos

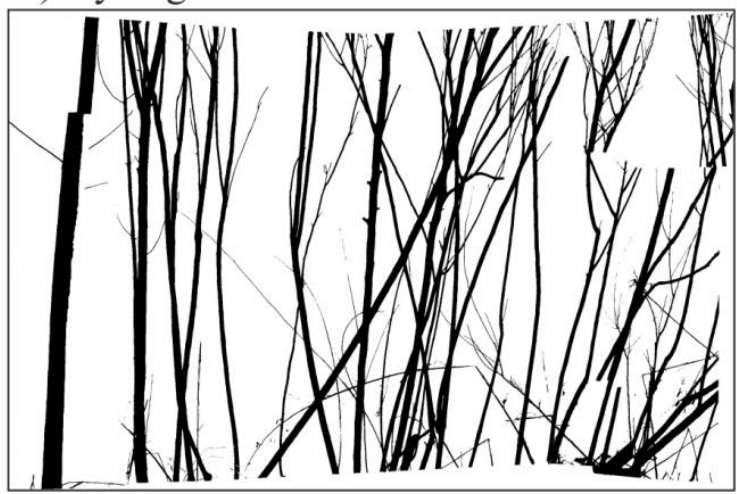

21. ábra. Különbözö felszínboritási kategóriákban a PP-módszerrel felmért növényzet fotómozaikjai (A-C). Az „a” képek a jelenlegi, gyalogakáccal fertözött állapotokat mutatják, míg a „b” képekröl letöröltem a gyalogakácot. A C-gyalogakácos felszínboritási kategóriában készült képen minden egyed gyalogakác

A felszínborítás megváltozásával és az invazív gyalogakác elterjedésével párhuzamosan a hullámtér növényzeti érdessége (n) is jelentős változásokon ment keresztül (22. ábra). Minden egyes hullámtéri területegységre a felszínborítási kategóriák alapján kiszámítottam az átlagos növényzeti érdességet a különböző felmérési időpontokban. Az árvízvédelmi töltések kiépítése elött (1784-ben), amikor a felszín nagy része időszakos vagy állandó vízborítás alatt állt, a felszín növényzeti érdessége nagyon kicsi volt $(\mathrm{n}=0,023)$. A töltésrendszer kiépítését követően, ahogy a mocsaras térszíneket felváltották a rétek és legelők, illetve ahogy ezek fokozatos beerdősülésnek indultak, a növényzeti érdesség is fokozatosan nőni kezdett. Míg értéke 1864-ben 0,035 volt, addig két évtizeddel később, 1884-ben már 0,048-ra nőtt. Az ezt követő közel 100 éves időszakban az intenzív erdőtelepítések, illetve a rétek és legelök beerdősülésének hatására az érdesség a 1,5-szeresére nőtt, értéke 1980-ban n=0,078 volt. A 2017. évi Goggle Earth légifelvételek alapján a hullámtér növényzeti érdessége $n=0,09$-nek adódott. Az eddig bemutatott felmérések és felvételek alapján számított növényzeti érdességet a Chow (1959) által megadott érdességi értékek alapján számítottam ki, amelyek azonban nem jelzik a különböző invazív növényfajok hatását. A 2017 telén végzett terepi felmérések 
segítségével kiszámított érdességek viszont jóval magasabb értékeket mutatnak a csupán irodalmi adatok alapján számított értékeknél, hiszen méréseim szerint a gyalogakác jelenléte átlagosan 0,02-vel megnöveli a teljes hullámtér növényzeti érdességét $(n=0,11)$, így ennek feltöltődésre gyakorolt hatása igen jelentős lehet.

A növényzeti érdesség változása nem csak időben változott, de a vizsgált alsó-tiszai ártéren is eltéréseket mutat (22. ábra), amelyek elsősorban a 2017-es adatokban mutatkoznak meg. A következőkben az általam mért, a 2017-es állapotokat tükröző érdességi adatokat jellemzem részletesen, mert véleményem szerint ezek az értékek felelnek meg leginkább a valóságnak, nem pedig az irodalmi adatok alapján súlyozott érdességi adatok. A mintaterület egészén a felszín növényzeti érdessége átlagosan $0,11(\mathrm{n}=0,02-0,13)$, és a hullámtér jobb és bal oldalának átlagos érdességei között nincs különbség, mindkét oldalon egyaránt 0,11 , ugyanakkor a bal oldali hullámtéren kevesebb kis érdességü folt van, így itt az értékek szükebb $(n=0,06-0,13)$ határok között mozognak, mint a jobb oldalon $(n=0,02-0,13)$. Az alacsonyabb érdességi értékek $(\mathrm{n}=0,03-0,06)$ a hullámtér beépítettségének és gondozásának köszönhetők, amely elsősorban a folyóhoz közel elhelyezkedő települések környékén figyelhető meg. Például Csongrádnál a T12-13 területegységekben, Mindszentnél a T38 egységben és Szeged környékén a T70, T74-78 és T80-81 területegységekben figyelhetők meg alacsony növényzeti érdesség értékek.

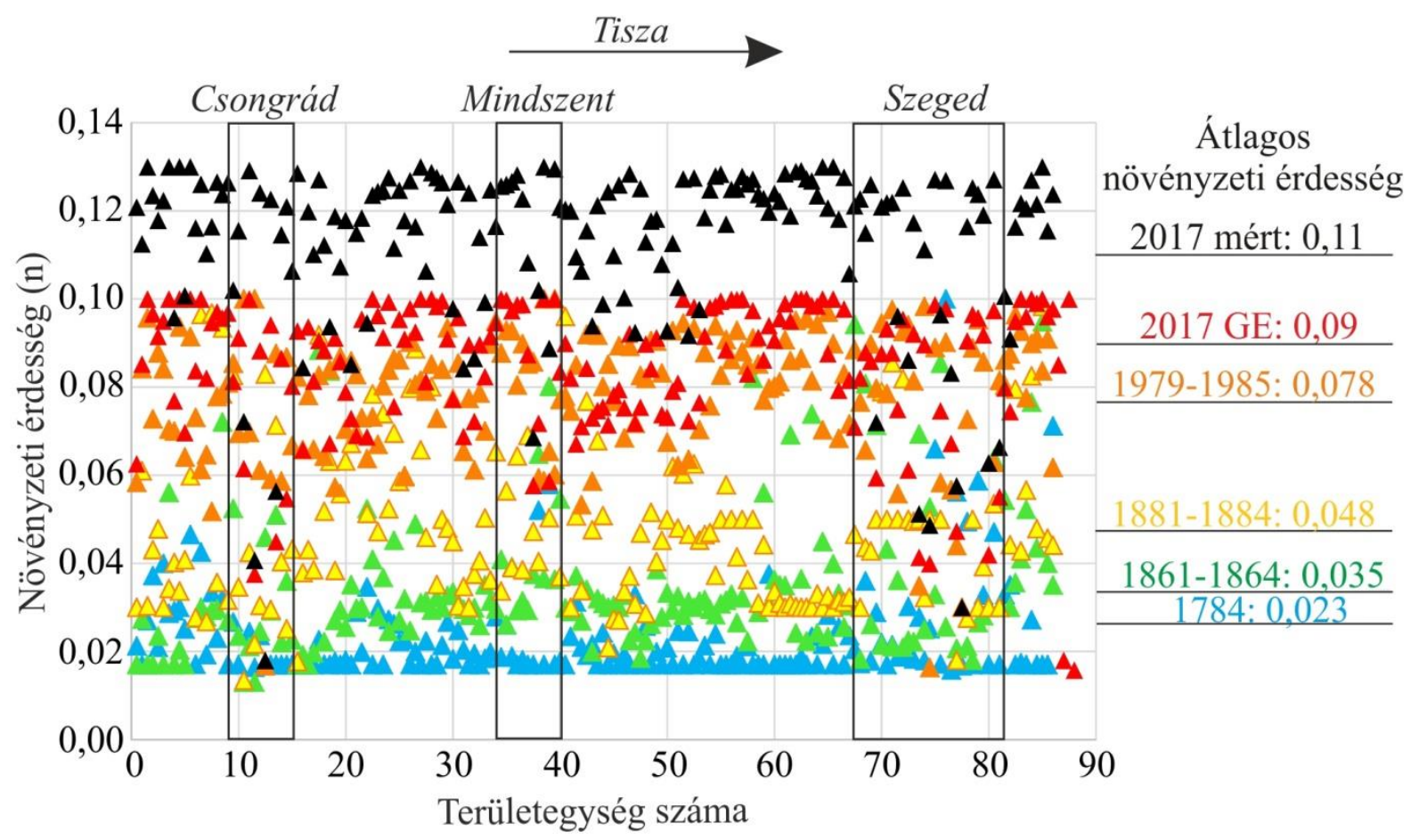

22. ábra. A felszín növényzeti érdességének változása a 18. század vége óta az Alsó-Tisza menti hullámtéren

Napjainkban a területegységekben mért különböző növényzeti érdességek közül a legkisebb arányban $(1,7 \%)$ a kis érdességi értékek $(\mathrm{n}=0,02-0,04)$ fordulnak elő $(23$. ábra), amelyek Chow (1959) osztályozásában a mesterséges és csupasz felszíneknek, réteknek és legelőknek, valamint a szántóterületeknek felelnek meg. Az elszórt fákkal és bokrokkal tarkított rétekre és legelökre, a gyümölcsösökre és kertekre n=0,05-0,07 jellemzők (Chow 1959), amelyeket nem fertőzött meg gyalogakác. Ezen érdességekkel rendelkező területegységek aránya is alacsony $(5,2 \%)$ a teljes hullámtéren belül. A nagyobb növényzeti érdesség értékek $(n>0,08)$ már az erdőterületeket jelölik. A hullámtér nagy növényzeti érdességét jól mutatja, hogy míg a ritkább erdőknek számító területek $(n=0,08-0,10)$ aránya mindössze $15,8 \%$, addig a már a nagyon sürü $(n=0,11-0,13)$, javarészt invazív fajokkal fertőzött és kezeletlen erdőterületek aránya 77,3\%. 


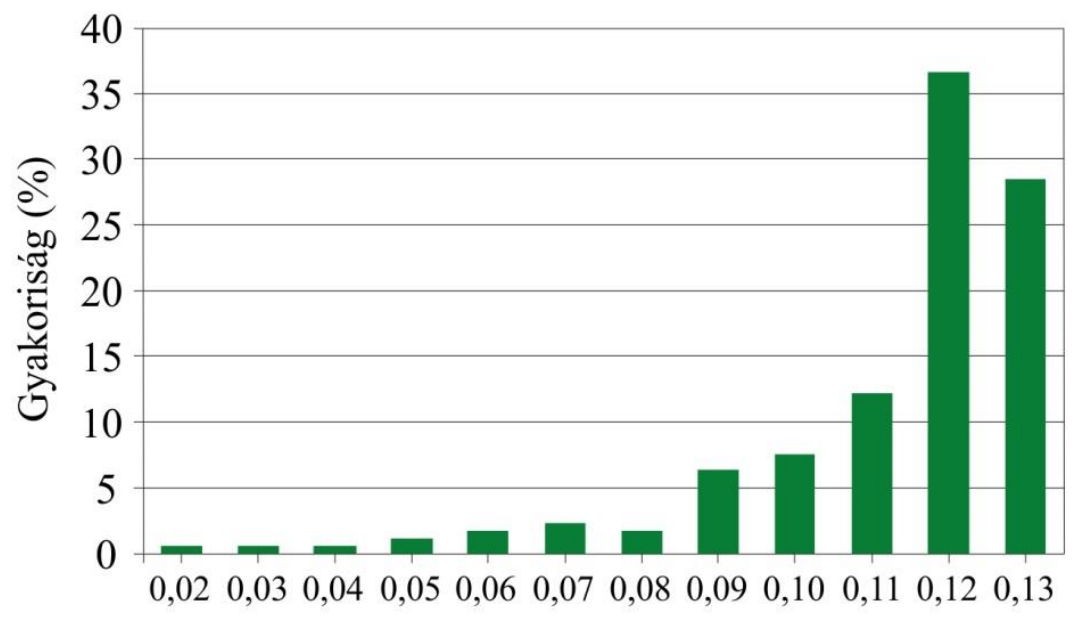

Növényzeti érdesség (n)

23. ábra. A különbözö növényzeti érdességi értékek elöfordulásának gyakorisága az AlsóTisza mentén lehatárolt területegységekben

A növényzet hordalék felhalmozódására gyakorolt hatása azonban elsősorban a part menti legfeljebb 150 m-es sávban érvényesül (Sándor 2011), így kiszámítottam minden területegységen belül, hogy a parttól számított 150 m széles sávban hogyan alakul a felszín növényzeti érdessége. Az eredmények a teljes területegységekben mért arányokhoz hasonlóak, azzal a különbséggel, hogy itt még hangsúlyosabb a nagyon sürü erdővel borított területegységek aránya (79,1\%), így a parti sáv átlagos növényzeti érdessége 2017-ben 0,12 volt.

A növényzet hordalék-felhalmozódásra gyakorolt hatásának megállapításához összevetettem az egyes területegységekben mért feltöltődés értékeket $(\mathrm{m})$, illetve a terepi méréseim alapján számított növényzeti érdességi értékeket. Ezt az elemzést csupán a part menti $150 \mathrm{~m}$-es sávban végeztem el, hiszen ez az a sáv, ahol a növényzet közvetlenül meghatározza a feltöltődés vastagságát (Sándor 2011), míg a belsőbb területeken az áramlási viszonyok (pl. vízsebesség, áramlás iránya, vízmélység) nagyon változatosan alakulhatnak, így ott a növényzet teljesen más hatásmechanizmusokon keresztül hathat. Az elemzésbe belevettem a hullámtér-szélesség hatását is, ugyanis több területegységben a hullámtér $150 \mathrm{~m}$ nél szükebb, így hatása meghatározó lehet a növényzet mellett.

A hullámtér szélessége alapján a területegységek két csoportba sorolhatók, megkülönböztettem széles $(>150 \mathrm{~m})$ és szük $(\leq 150 \mathrm{~m})$ szakaszokat. A csoportok kialakítását azért tartottam szükségszerünek, mert az egyes területegységekben jellemző hordalékvastagság és a felszín növényzeti érdessége között a kapcsolat nehezen megállapítható volt, amikor az összes területegységet egyszerre vizsgáltam.

A széles hullámtereken a hullámtér szélességének hordalékvastagságra gyakorolt hatása nem mutatható ki (ld. 5.1.2 B fejezet). A part menti sáv növényzeti érdessége ebben a csoportban $n=0,05$ és $n=0,13$ között változik. Az érdesség és a feltöltődés közötti kapcsolat viszont mutatja, hogy a hordalék vastagsága $\mathrm{n}=0,08$ érdességig nő, azután pedig csökkenésnek indul (24. ábra). Mindez azt mutatja, hogy az $n=0,08$ növényzeti érdesség egy küszöbértéket jelent a hordalék-felhalmozódás szempontjából: ahogy sürüsödik a növényzet (pl. a part menti rét vagy legelő elkezd beerdősülni, vagy a gyalogakác terjedni kezd), az érdesség növekedése miatt az ártérre kilépő víz sebessége egyre nagyobb mértékben mérséklődik, így az áramló víz hordalékszállító képessége csökken, azaz a part menti növényzet egyre nagyobb mennyiségü hordalék felhalmozódását eredményezi. Ezen felszínérdesség felett $(\mathrm{n}>0,08)$ azonban a part menti növényzet sürübbé válásával nem nö, hanem csökken a feltöltődés vastagsága. Terepi tapasztalataim szerint a partokon helyenként áthatolhatatlanul sürü növényzet nő, ami árvizekkor szürőként vagy szivacsként viselkedhet. Azaz nagy valószínủséggel a vízáramlás sebessége olyannyira lecsökkenhet már a partélnél, 
hogy a hordalék nem jut el a parttól távolabbi területek felé. Azonban ezt nem tudtam ellenőrizni, ugyanis a kutatási időszak alatt nem fordult elő a partéleken átbukó magasságú árvíz, amikor vízsebesség méréseket végezhettünk volna.

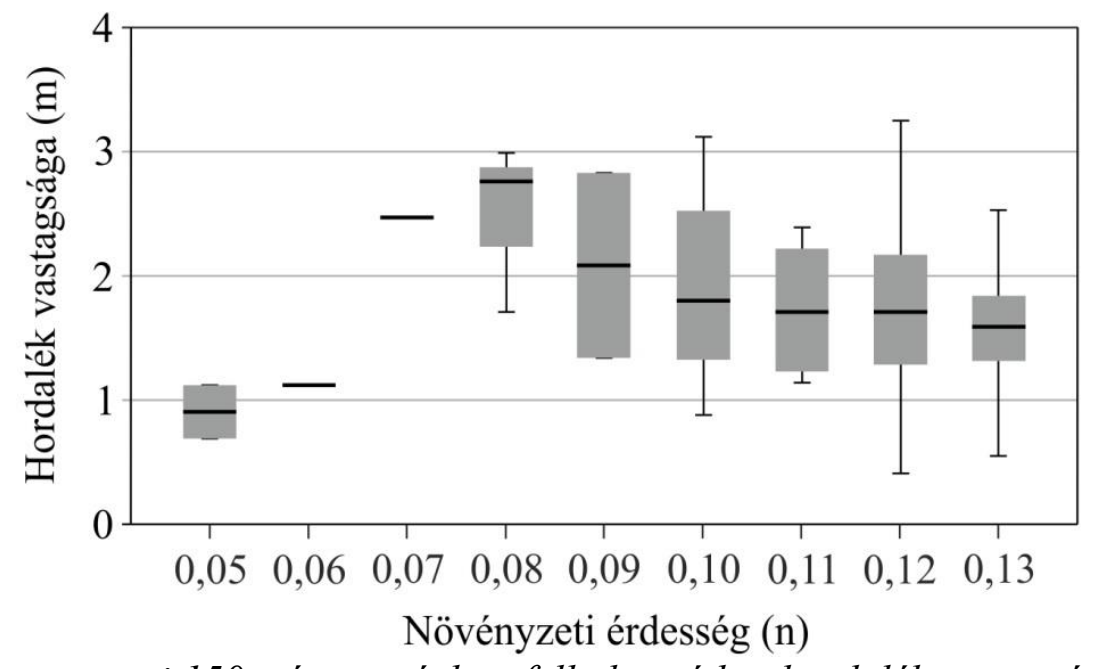

24. ábra. A part menti 150 méteres sávban felhalmozódott hordalék vastagsága különbözö növényzeti érdességü területeken széles (>150 m) hullámtéri területegységekben

A második csoportot azok a területegységet képezik, ahol a hullámtér 150 méternél szükebb. Ez jóval kevesebb, mindössze 42 területegységben jellemző, azonban ezek közül csak 36 esetében volt vizsgálható a feltöltődés, hiszen 6 területegység olyan területen helyezkedik el, ahol a felhalmozódás vastagsága nem volt meghatározható a mentett ártéri területek mesterséges megmagasítása miatt (pl. Szeged: T 75, 77-78 és 80).

Ezekben a szűk hullámtéri egységekben felhalmozódott hordalék vastagága kapcsolatot mutat a növényzeti érdességgel és a hullámtér szélességével is (25. ábra). A növényzeti érdesség esetén az elöbbi területegység-csoportnál megfigyelt összefüggés figyelhető meg. Az $\mathrm{n}=0,08$ érdesség ebből a csoportból habár hiányzik, de feltehetőleg a hordalék felhalmozódásában szintén ez jelentheti a küszöbértéket, ugyanis az $n=0,07$ érdesség esetén az átlagos hordalékvastagság 1,7 m (0,9-2,2 m), míg a n=0,09 érdességü területegységekben pedig 1,5 m (1,1-2,1 m). Azonban a nagyon sürü növényzettel $(\mathrm{n}>0,12)$ rendelkező egységekben ismét megfigyelhető a hordalék-felhalmozódás intenzívebbé válása. Véleményem szerint ennek oka a szük hullámtérben keresendő, ugyanis a feltöltődés vastagsága a hullámtér szélességével is mutat kapcsolatot. A két tényező között fordított arányosság jellemző $\left(\mathrm{R}^{2}=0,34\right)$, azaz minél szükebb a hullámtér, a felhalmozódó hordalékréteg annál vastagabb. A nagy növényzeti érdességgel $(n>0,12)$ jellemezhető egységekben fellépő intenzívebb akkumuláció okát abban látom, hogy habár nagy érdesség esetén a hordalék-felhalmozódásnak csökkennie kellene, de a nagyon szük hullámtér miatt a két tényező hatása kombinálódik, így nagyobb mennyiségü hordalék képes akkumulálódni. 

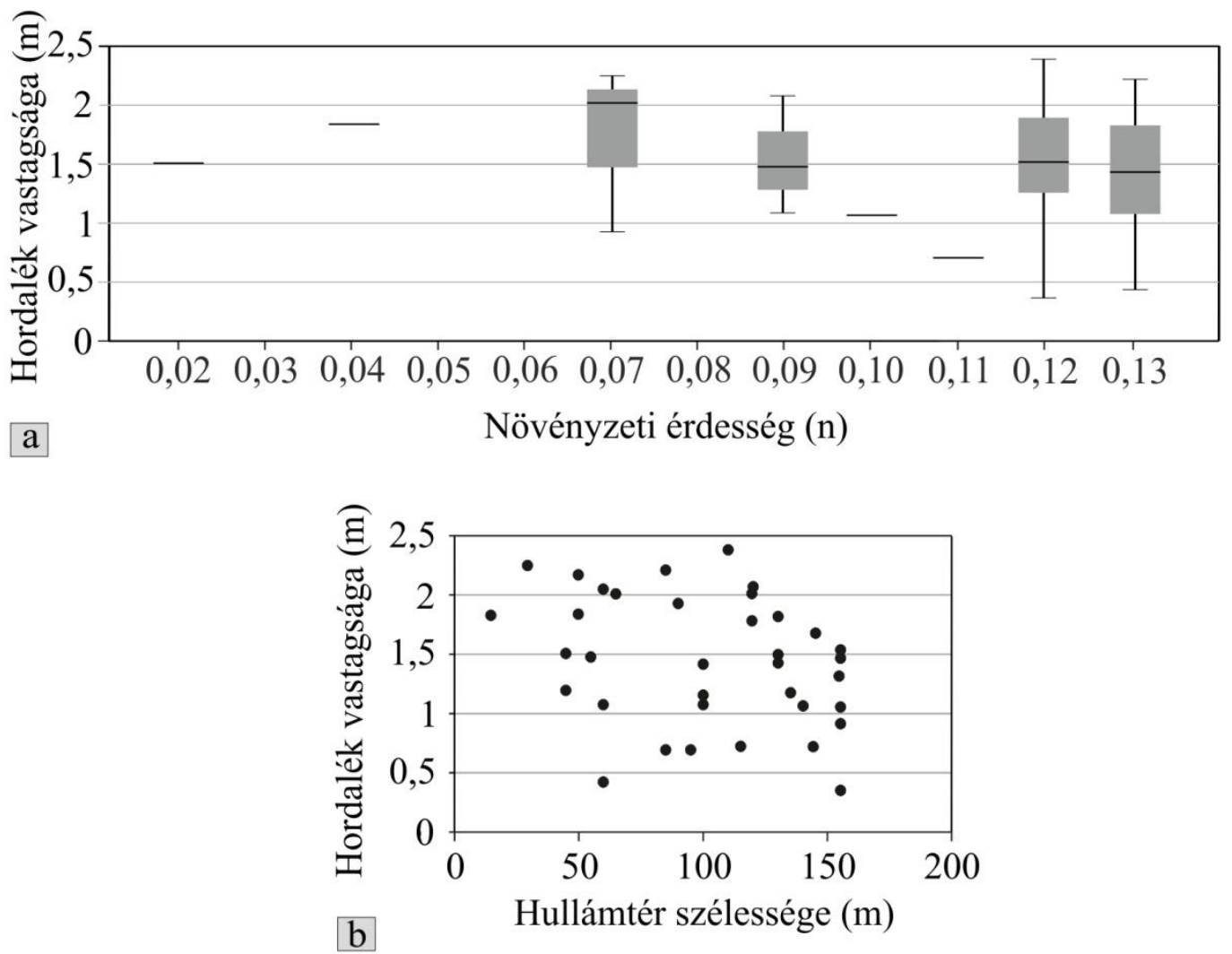

25. ábra. Szük $(<150 \mathrm{~m})$ hullámterü területegységekben a part mentén felhalmozódott hordalék vastagsága különbözö növényzeti érdességek esetén (a), és a hullámtér szélességének függvényében (b)

\section{D) A hullámtér feltöltödését befolyásoló tényezők összevetése}

A fejezetben a hordalék felhalmozódását a hullámtér teljes szélességében befolyásoló tényezők, azaz a hullámtér-szélesség, a felszín növényzeti érdessége és a beömlő mellékfolyók hatásának vizsgálatával foglalkoztam. Eredményeim szerint az árvízvédelmi töltések óta felhalmozódott hordalék térfogatát egyértelmüen a hullámtér szélessége határozza meg, míg az üledék vastagságát több tényező együttes hatása befolyásolja. A beömlő mellékfolyók csupán a torkolat közelében, a felvízi és alvízi irányban elhelyezkedö 4-5 km hosszú szakaszon befolyásolják a Tisza hullámterének feltöltődését. Ezt a hatást azonban felülírhatja a hullámtér szélessége és a folyók különböző esése, amelyek a Tisza fajlagos munkavégző képességére hatnak. A növényzeti érdesség hatása elsősorban a part menti szükebb, $150 \mathrm{~m}$-széles sávban érvényesül, azonban ez is eltér a különböző szélességü hullámtéri szakaszokon. Széles (>150 m) hullámtéren az $n=0,08$ érdességi érték egy küszöbértéket jelent a feltöltődés szempontjából, amely alatt az érdesség növekedésével a felhalmozódás is egyre intenzívebb, míg ezen érték felett egyre kevesebb hordalék akkumulálódik a parttól távolabbi területeken. Szük hullámtéri szakaszokon ( $\leq$ $150 \mathrm{~m})$ azonban a hullámtér szélessége és a magas növényzeti érdesség $(\mathrm{n}=0,12-0,13)$ hatása kombinálódik, amely intenzívebb hordalék-felhalmozódásban nyilvánul meg.

A fejezetben bemutatott eredmények azt mutatják, hogy a különböző, a feltöltődést a hullámtér teljes szélességében befolyásoló tényezők hatását nehéz elkülöníteni, és a paraméterek közötti egyértelmü kapcsolatok felállítása és bizonyítása csupán statisztikai módszerekkel nem feltétlenül lehetséges. Ennek okát abban látom, hogy a feltöltődést befolyásoló paraméterek - a hullámtér-szélesség kivételével - térben is időben is folyamatosan változnak. Azt, hogy a hullámtéren mennyi hordalék halmozódik fel, az árvizek hidrológiájától és a lebegtetve szállított hordalék mennyiségétől függ. Ezen tényezőket dolgozatom megírása során nem volt alkalmam megvizsgálni, ugyanis a kutatásom időtartama alatt nem fordult elő a partéleken átbukó vízállás, 
azonban ezek a tényezők alapvetően befolyásolják a hullámtér feltöltődését. Az egyes árhullámoknak minden árvízi esemény alkalmával más a hidrológiája, ugyanazon szakaszon (1) más vízállással tetőznek; (2) eltérö a tartósságuk, amely meghatározza, hogy a hordalék kiülepedésére milyen hosszú idő áll rendelkezésre; (3) más a vízhozamuk; illetve (4) ugyanazon árhullám egy hosszabb folyószakasz felvízi és alvízi részén is eltérő tulajdonságokkal rendelkezhet. Másrészt a Tisza lebegetett hordalékhozama is pontról pontra változhat, hiszen egy adott szakaszon lerakódott üledék egy másik szakaszon újratermelődik, így a víz hordaléktöménysége folyamatosan változik. Továbbá a Tisza hordalékhozama időben is változott, hiszen a mederrendezési munkálatokat követően a nagyobb esés következtében megnőtt fajlagos munkavégző képesség megnövekedett hordalékmennyiséget eredményezett, amely alapján feltételezhetö, hogy közvetlenül a szabályozások után intenzívebb feltöltődés zajlott.

A hullámtéren a hordalék-felhalmozódást lokálisan befolyásoló tényezők, mint a betorkolló mellékfolyók és a felszín növényzettel való borítottsága a szabályozást követően és napjainkban eltérő mértékben fejtették ki hatásukat. A mellékfolyók közül a Hármas-Körös hordalékszállításában jelentős változás következett be az 1900-es évek első évtizedét követően. A folyón megépített két duzzasztó miatt lecsökkent a folyó hordalékhozama, amely az Alsó-Tisza Csongrád környéki szakaszán módosítja a hordalékszállítási viszonyokat. Ez azonban csak a duzzasztóművek kiépítését követően jellemző, így az 1900-as évek elejét megelőzően a HármasKörös jóval nagyobb hordalékmennyiséggel járulhatott hozzá a Tisza hordalékszállításához, így a torkolat alatti hullámtéren is több akkumulálódhatott.

Eredményeim jól mutatják, hogy a hullámtér növényborítottsága, ezáltal a felszín növényzeti érdessége jelentős változásokon ment keresztül az elmúlt közel 200 évben. A felszínborításban bekövetkezett változások azonban nehezen nyomon követhetők, mert egyrészt csupán néhány térképezés alapján lehet meghatározni a hullámteret borító növényzet típusát, másrészt a korábbi időszakokra vonatkozó pontos növényzeti érdességi adatok nem léteznek, amelyeket így csak közvetve, szakirodalmi adatok súlyozásával lehet meghatározni. Az általam terepen mért érdességi értékek is néhány pont adataira támaszkodnak, és a különbözö területegységekben csupán átlagos értékeket mutatnak. Az érdesség ezen térbeli pontatlansága és időbeli változása miatt a hordalék-felhalmozódás és a növényzeti érdesség között nem mutatható ki egyértelmü kapcsolat.

Hosszú távon az áramlási viszonyok is megváltoztak a hullámterén, egyrészt a felszínborítás megváltozásának, a part menti növényzet sürübbé válásának eredményeképpen, másrészt pedig a feltöltődés miatt a partok magassága folyamatosan emelkedik, amely az árvízi elöntések hosszát is módosítja.

Összességében a feltöltődés mértéke és az azt befolyásoló tényezők között szignifikáns statisztikai kapcsolatokat nem lehet egyértelműen meghatározni a hordalék-akkumulációt befolyásoló paraméterek folyamatos tér-és időbeli változása miatt. Véleményem szerint annak oka, hogy a legtöbb esetben a hullámtér szélessége felülírja a többi tényező hatását az, hogy ez az egyetlen paraméter, amely közel 150 éve térben és időben is változatlan.

\subsubsection{A hullámtér vízvezetö-képességének csökkenése}

Az 19. század során végrehajtott ármentesítési munkálatok következtében a hullámtéren intenzívebbé vált a hordalék-felhalmozódás, ami csökkenti az árvizek levezetésére szolgáló hullámtéri térfogatot, azaz romlik a hullámtér vízszállító-képessége. A hullámtér e képességének romlását az egymást $1 \mathrm{~km}$-enként követő területegységekben számítottam ki, külön a jobb és a bal oldali hullámtérre. Eredményeim szerint az Alsó-Tisza mentén a teljes hullámtér vízszállítóképessége átlagosan 22,6\%-kal romlott, a jobb (23,7\%) és bal oldali $(21,4 \%)$ hullámtéren is közel azonos mértékü csökkenés következett be. A csökkenés mértéke területegységenként $0-52 \%$ közötti, azonban a vízszállító-képesség romlása térben változatos képet mutat, a leggyakoribb (az egységek harmadában) esetben a vízvezető képesség 21-30\%-al romlott a feltöltődés következtében (26. ábra). 


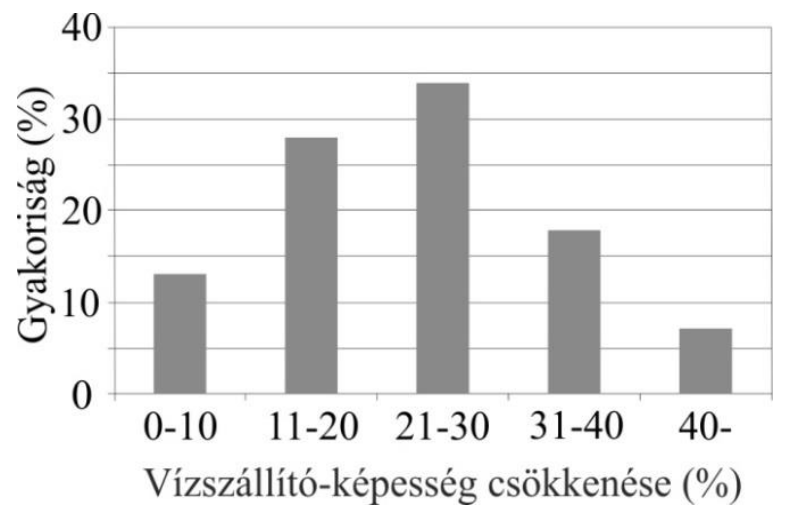

26. ábra. A különbözö vizszállitó-képességromlással rendelkezö területegységek gyakorisága az Alsó-Tisza mentén

A legnagyobb vízszállító-képesség csökkenéssel (> 40\%) jellemezhető szakaszok Csongrád, Mindszent-Mártély térségében, Algyőnél, illetve Szegedtől délre találhatók (27. ábra).

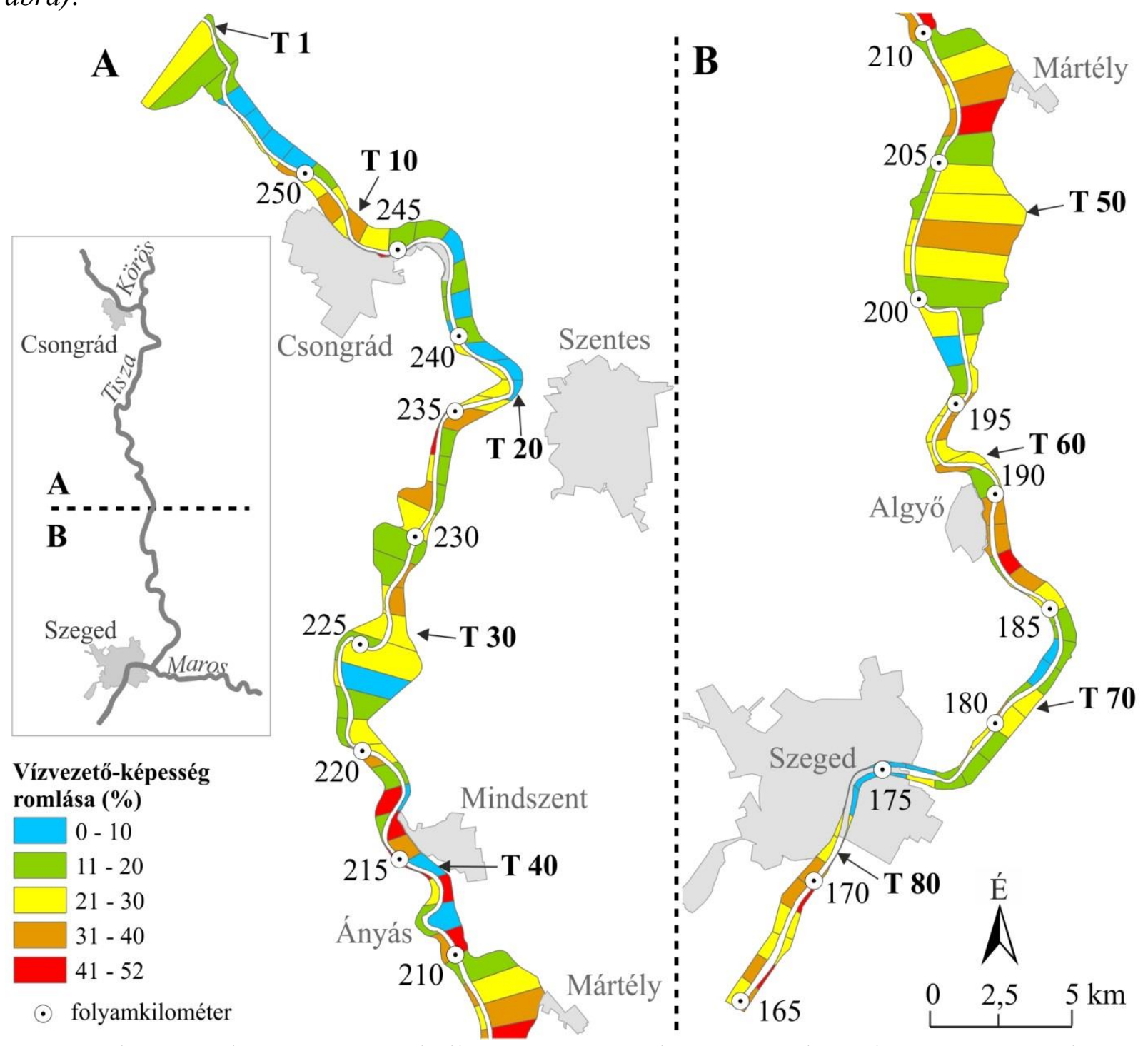

27. ábra. Az Alsó-Tisza menti hullámtér vízvezetö-képességének romlása a 19. századi ármentesitési munkálatok óta zajló feltöltödés következtében 
Csongrádnál a jobb oldalon a vízszállító-képesség csökkenése egy jóval hosszabb szakaszon (T7-12) figyelhető meg, míg a bal oldalon csupán 2 területegységet (T9-11) érint. Csongrádtól délre szintén a hullámtér jobb oldalán tapasztalható hosszabb szakaszon (T22-25) nagyobb csökkenés, míg a hullámtér túl oldalán csak a T21 egységben haladja meg a vízszállító-képesség romlása a 30\%-ot. Ezt követően Mindszent-Mártély térségében egy közel 10 km-es szakaszon számos egységben (T18-26) jelentős a hullámtér vízszállító képességének csökkenés, amely mind a jobb és a bal oldalon megfigyelhető. A mártélyi öblözet alvízi ágában mért csökkenés azonban túlbecslés lehet, hiszen a vízszállító-képesség jelentős romlása nem a hullámtér feltöltődéséből adódik, hanem abból, hogy ebben az egységben egy, a felszín fölé 1-2 m-rel magasodó ártéri színt nyúlik be a jelenlegi hullámtérbe, amely a felszín nagyobb átlagmagasságát eredményezi. Ezt követően Algyő térségben 4 egységben (T62-65), a jobb és a bal oldalon is jelentősen lecsökkent a hullámtér vízszállító-képessége. Végül Szegedtöl délre egészen a mintaterület alsó határáig (T81-86) megfigyelhető a vízszállító-képesség romlása, amely ezen a szakaszon is mind a két oldalon jellemző.

Összességében a legintenzívebb feltöltődéssel rendelkező, ezáltal legrosszabb vízszállító-képességü területek elsősorban azokban az egységekben fordulnak elö, ahol a hullámtér szélessége kicsi vagy jelentően lecsökken. Bár a legszükebb hullámtéri szakasz (kb. $120 \mathrm{~m})$ Szegednél van, itt a vízszállító-képesség csökkenése mégis $10 \%$ alattinak adódott. Ennek mérési hiba lehet az oka, ugyanis a felhalmozódott hordalék vastagságának kiszámításakor ezen a szakaszon nem tudtam pontosan meghatározni a töltések közötti hullámtér és a mentett ártéri terület közötti magasságkülönbséget az utóbbi mesterséges megmagasítása miatt.

Véleményem szerint ezeken a legrosszabb vízszállító-képességgel rendelkező szakaszokon kell javítani a hullámtéren az áramlási viszonyokat. Ez megvalósítható lenne például a mederrel párhuzamosan elhelyezkedő vízvezető sávok kialakításával, hiszen a felgyorsult vízáramlás miatt megnövő fajlagos munkavégzö-képesség hatására kevesebb hordalék tudna akkumulálódni a hullámtéren. Az invazív gyalogakác miatt jelentősen megnőtt növényzeti érdesség kedvez a hordalék felhalmozódásának. A gyalogakác irtásával, az ültetett erdők megfelelő és rendszeres gondozásával, illetve az eredeti felszínborítási kategóriák (rétek, legelők, szántók) visszaállításával és legeltetésével csökkenthető lenne a felszín növényzeti érdessége, ezáltal mérséklődne a hordalék akkumulációja is. Az áramlási viszonyok javulását eredményezhetné a hullámtéren belüli mesterséges akadályok (illegális hulladéklerakók, tuskógátak) felszámolása is. A nagyon rossz vízszállító-képességü (gyakorlatilag hordalékdugóként funkcionáló) szakaszok árvizek idején a hullámtér kritikus pontjait jelentik, így ezeken a szakaszokon célszerü lenne a töltésmagasságokat átgondolni, esetleg azok magasítását célul kitüzni.

\subsection{A vertikális feltöltődés kiemelt helye: a folyóhátak fejlődése}

\subsubsection{A kanyarulatok csoportjai fejlettségük alapján}

A folyóhát-fejlődés vizsgálatának szempontjából fontos befolyásoló tényező a kanyarulatok fejlettsége. Ez ugyanis meghatározza a hullámtérre kijutó víz energiáját, ezáltal a lebegtetett hordalék mennyiségét is (Fiala 2002, Hudson és Heitmuller 2003, Sándor 2011), amely jelentősen befolyásolhatja a folyóhátak alaktani tulajdonságait és épülésük ütemét.

$\mathrm{Az}$ Alsó-Tisza mentén vizsgált 39 kanyarulatnak fejlettségük alapján 4 csoportja különíthető el (28. ábra és 7. táblázat). Az álkanyarok kis számban fordulnak elö, a kanyarulatoknak csupán 15\%-a tartozik ide. Általában nagy görbületi sugárral rendelkeznek $\left(\mathrm{R}_{\mathrm{c}}>1000 \mathrm{~m}\right)$. Mindegyik álkanyar olyan szakaszokon található, amelyeket a mederrendezési munkálatok során kiegyenesítettek, és amelyek a szabályozásokat követően enyhén kanyargásnak indultak. 
A fejletlen kanyarulatok csoportjába a kanyarulatok 37\%-a tartozik, amelyek szintén nagy görbületi sugárral rendelkeznek $\left(R_{c}>1000\right.$ $\mathrm{m})$, de három fejletlen kanyarulat esetében ez mindössze 500-1000 m közötti. Térbeli elhelyezkedésükre jellemző, hogy ezek többsége szintén a kiegyenesített szakaszokon találhatók, de fejlődésük már előbbre haladottabb, mint az álkanyaroké. Ebbe a két csoportba tehát a legfiatalabb kanyarulatok tartoznak, amelyek fejlődése legfeljebb 180 éve tart.

A mintaterületen szintén gyakoriak (38\%) a fejlett kanyarulatok. Közel feleakkora görbületi sugárral rendelkeznek, mint az ál-és fejletlen kanyarulatok (átlagosan $860 \mathrm{~m}$ ), és csupán két kanyarulat esetében figyelhető meg 1000 m-nél nagyobb görbületi sugár. Ezek többsége a mederrendezés során érintetlen szakaszokon fordul elö, tehát már a szabályozások elött is léteztek, így fejlődésük már hosszabb ideje tart.

Az utolsó csoportot az érett kanyarulatok alkotják, amelyek aránya az összes kanyarulaton belül mindössze $10 \%$. Ezek mindegyike kis görbületi sugárral rendelkezik $\left(\mathrm{R}_{\mathrm{c}}<750 \mathrm{~m}\right)$, és szintén azokon a szakaszokon találhatók, amelyeket a szabályozási munkálatok nem érintettek. A fejlett és érett kanyarulatok csoportjai tehát a legidősebb kanyarulatokat foglalják magukba, amelyek fejlődése legalább 180 éve tart.

Az Alsó-Tisza kanyarulatai tehát görbületi sugaruk, térbeli elhelyezkedésük és koruk alapján két nagyobb csoportra oszthatók, ál-és fejletlen kanyarulatokra, illetve fejlett és érett kanyarulatokra. A folyóhátak alaktani tulajdonságait és épülését befolyásoló tényezők vizsgálatakor az elemzéseket ezért erre a két csoportra vonatkozóan végeztem el, ugyanis a kanyarulatok különböző tulajdonságai eltérő mértékben befolyásolhatják a folyóhát-épülés folyamatát.

7. táblázat. Az Alsó-Tisza menti kanyarulatok fejlettsége és görbületi sugara

\begin{tabular}{|l|c|c|}
\hline \multicolumn{1}{|c|}{ Kanyarulat típusa } & Fejlettség ( $\boldsymbol{\beta})$ & $\begin{array}{c}\text { Átlagos (min.-max.) } \\
\text { görbületi sugár (m) }\end{array}$ \\
\hline Álkanyar & - & $2097(1033-2748)$ \\
\hline Fejletlen kanyarulat & $<1,2$ & $2015(516-4198)$ \\
\hline Fejlett kanyarulat & $1,1-1,4$ & $860(155-1862)$ \\
\hline Érett kanyarulat & $1,4-3,5$ & $325(152-750)$ \\
\hline
\end{tabular}




\subsubsection{A folyóhátak általános alaktani jellemözi és fejlödésük üteme}

\section{A) A folyóhátak relatív magassága}

Az Alsó-Tisza mentén átlagosan 3,9 m (2,6-4,9 m) magas folyóhátak formálódtak. Négy kanyarulat mentén nem sikerült azonosítani a formákat, mivel két kanyarulat mentén a hullámtérről 2014-ben nem készült LiDAR felmérés (31-32. sz. kanyarulatok), illetve további kettő mentén (36-37. kanyarulatok) a felszín antropogén bolygatottsága miatt nem voltak kivehetők a formák. A folyóhátak magasságának folyásirányban történő trendszerü változása nem figyelhető meg, bár kijelölhetők olyan rövidebb-hosszabb szakaszok, ahol hasonló magasságú formák alakultak ki (29. ábra). A mintaterület északi részén (1-5. sz. kanyarulok) a formák átlagosan 3,8 m magasak, egy kanyarulat kivételével mindegyik forma magassága 3,5 m felett van. A 6 . számú kanyarulat mentén alakult ki a mintaterület legalacsonyabb folyóhátja, magassága mindössze 2,6 m, de az öt követő kanyarulat (7. sz) külső ívén fejlődött forma is alacsony (3,3 m). Ezt követően (8-14. sz. kanyarulatok) a folyóhátak magassága ismét megnő (átl. 4,1 m). A legmagasabb formák a 15 . és 16 . sz. kanyarulatok mentén alakultak ki, magasságuk közel $5 \mathrm{~m}$ (4,8 és 4,9 m). A 17-23. sz. kanyarulatig terjedő folyószakaszon a formák magassága lecsökken, itt találhatók a legkisebb átlagmagassággal rendelkező formák (átl. 3,4 m), majd a következő 4 kanyarulat mentén (24-27. sz.) ismét magasabb (átl. 4,3 m) folyóhátak alakultak ki. Ettől a szakasztól folyásirányban lefelé (28-39 kanyarulatok) azonban a folyóhátak magassága kanyarulatonként jelentős mértékben változik, illetve itt találhatók azok a kanyarulatok, amelyek mentén nem sikerült a folyóhátakat azonosítani.

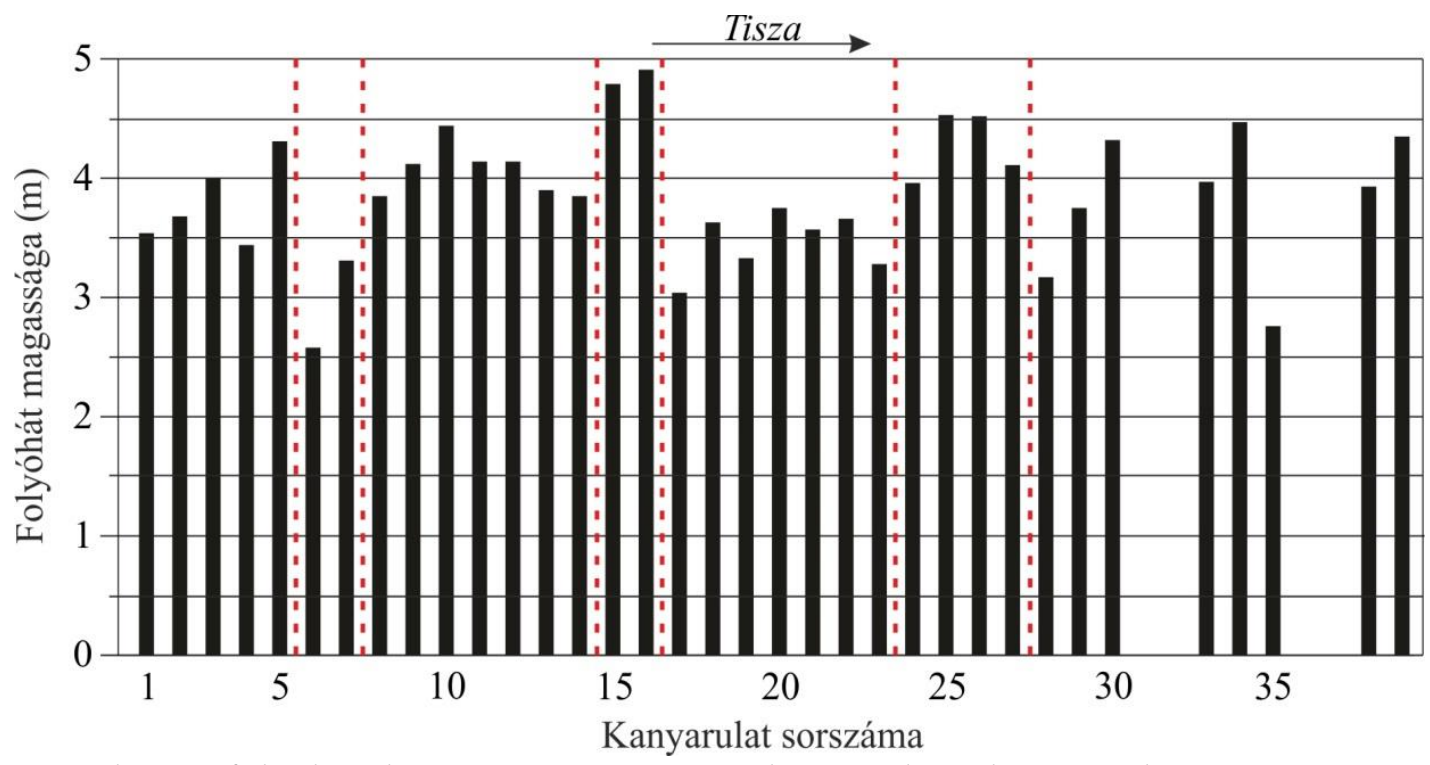

29. ábra. A folyóhátak magassági viszonyai kanyarulatonként az Alsó-Tisza mentén

\section{B) A folyóhátak szélessége}

A folyóhátak szélességi viszonyai jóval változatosabb képet mutat, mint az előbb bemutatott magassági jellemzők (30. ábra). A formák szélessége kanyarulatonként jelentősen változik, így olyan szakaszokat, amelyek mentén hasonló jellemzőkkel rendelkező folyóhátak alakultak ki, nem tudtam elkülöníteni. A mintaterület egésze mentén a folyóhátak átlagos szélessége $154 \mathrm{~m}$, de előfordulnak igen keskeny $(25 \mathrm{~m})$ és nagyon széles $(550 \mathrm{~m})$ formák is. A legkeskenyebb formák $(25-50 \mathrm{~m})$ Csongrád térségében a 6 . sz. kanyarulat mentén, a mintaterület középső részén, Mindszent térségében a 20. és 24. sz. kanyarulat mentén, illetve Szegedtől folyásirányban felfelé a 34. és 34 . sz. kanyarulatok mentén alakultak ki. Ezek 
mindegyike egybeesik a legszükebb hullámtéri szakaszokkal, ahol a hullámtér szélessége 100 m-nél szükebb. Itt azt tapasztaltam, hogy a folyóhátak nem simulnak a gát lábáig, hanem a folyóhátak egy meredek peremmel végződnek el, és mögöttük, a gát lábánál egy vízvezető sáv alakult ki. A legszélesebb folyóhátak $(>250 \mathrm{~m})$ ezzel szemben egybeesnek a jelentősen kiszélesedő hullámtéri szakaszokkal és széles öblözetekkel. Például az 5. számú kanyarulatnál 135 m-ről 750 m-re szélesedik a bal oldali hullámtér, így itt a külső íven $360 \mathrm{~m}$ széles folyóhát alakult ki, míg a 7. sz. kanyarulat esetében a Hármas-Körös betorkollásánál kiszélesedő hullámtér $(630 \mathrm{~m})$ lehet a széles $(250 \mathrm{~m})$ folyóhát kialakulásának oka. A mintaterület legszélesebb formája $(550 \mathrm{~m})$ a 15 . sz. kanyarulat mentén formálódott az Osztorai Holt-Tiszát magába foglaló hullámtéri öblözetben. Ezt követően Mindszenttől közvetlenül délre, a 21. sz. kanyarulat mentén alakult ki viszonylag széles $(260 \mathrm{~m})$ folyóhát, de ennek fejlődését sem korlátozta az adott oldali hullámtér szélessége $(450 \mathrm{~m})$. Folyásirányban lefelé, a 28. sz. kanyarulat külső ívén találunk egy igen széles $(360 \mathrm{~m})$ folyóhátat, azonban véleményem szerint itt a kanyarulat kis görbületi sugara is hozzájárulhat a forma nagy szélességéhez, amely több mint $2000 \mathrm{~m}$ széles hullámtérrel párosul. Végül Szegedtől délre, a 38. sz. kanyarulat mentén alakult ki egy széles $(310 \mathrm{~m})$ folyóhát, amely egy kiszélesedő (20 m-ről 500 m-re), de nem kimondottan széles hullámtéri területen alakult ki, bár a hullámtér még ennek a fejlődését sem korlátozza, de véleményem szerint itt a Maros által szállított nagy mennyiségü hordalék járulhat hozzá a forma nagy szélességéhez.

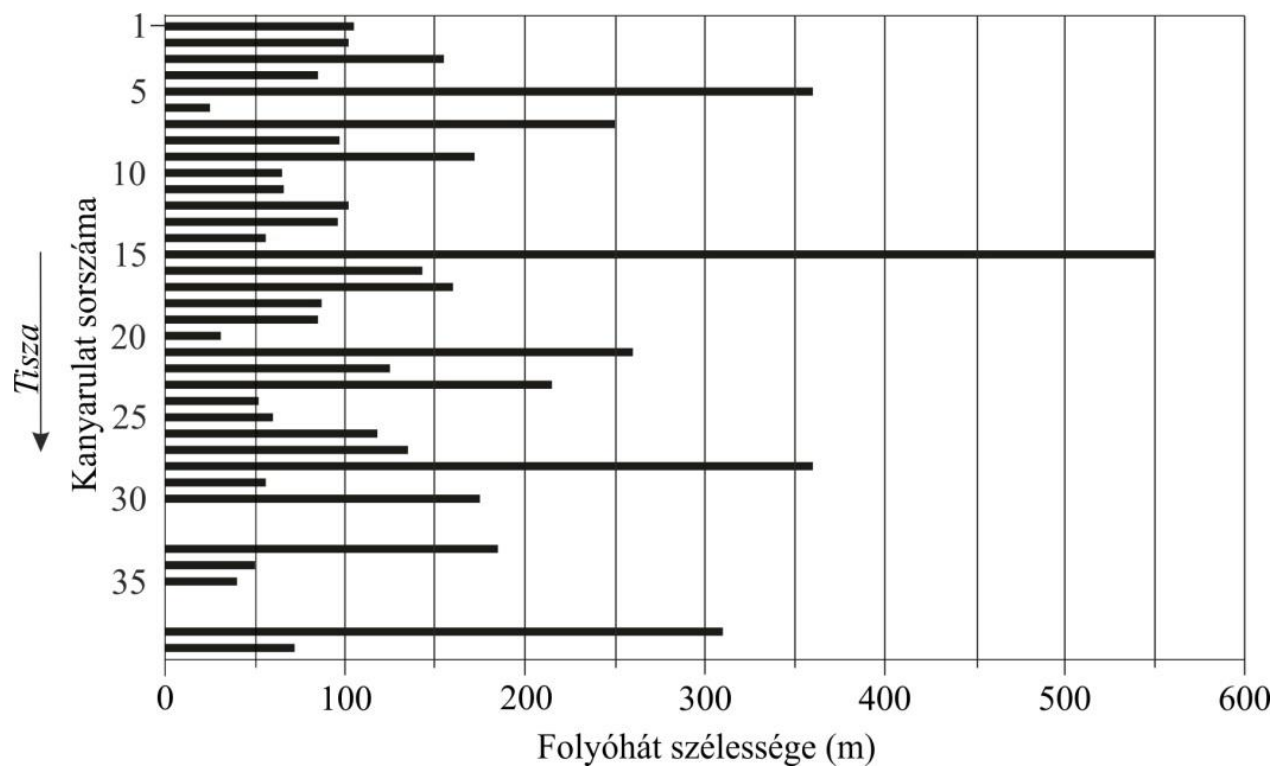

30. ábra. A folyóhátak szélességi viszonyai kanyarulatonként az Alsó-Tisza mentén

\section{C) A folyóhát-épülés üteme}

A folyóhátak szélességi viszonyaihoz hasonlóan nem különíthetők el olyan szakaszok, ahol a formák épülésének üteme hasonló ütemben zajlik (31. ábra), ráadásul a folyóhátak magassági viszonyaitól eltérően alakul a folyóhát-épülés ütemének térbeli trendje, amely azt sugallja, hogy a formák épülésének üteme és azok magassága között nem feltétlenül áll fenn egyenes arányosság, tehát a formák épülésének ütemét és magasságát eltérő tényezők befolyásolják.

Az Alsó-Tisza mentén a folyóhátak átlagosan $36 \mathrm{~mm} / \mathrm{é}$ ütemben épülnek, azonban ez kanyarulatonként 15-122 mm/év között változik. A legtöbb $(25 \mathrm{db})$ kanyarulat esetében a folyóhátak felszínén a hordalék-felhalmozódás átlagos üteme 15-30 mm/év között van. Ennél lassabb ütemü folyóhát-épülés nem fordul elö, míg ennél nagyobb ütemü felhalmozódás csupán 10 kanyarulat esetében figyelhető meg. Kiemelkedően gyors ( $>90 \mathrm{~mm} /$ év) épülés jellemzi a 19 ., 20., 24. és 26. sz. kanyarulatokat, azonban térbeli elhelyezkedésük alapján nem lehet következtetni az ezek mentén tapasztalható gyors hordalék-felhalmozódás közvetlen okára. 


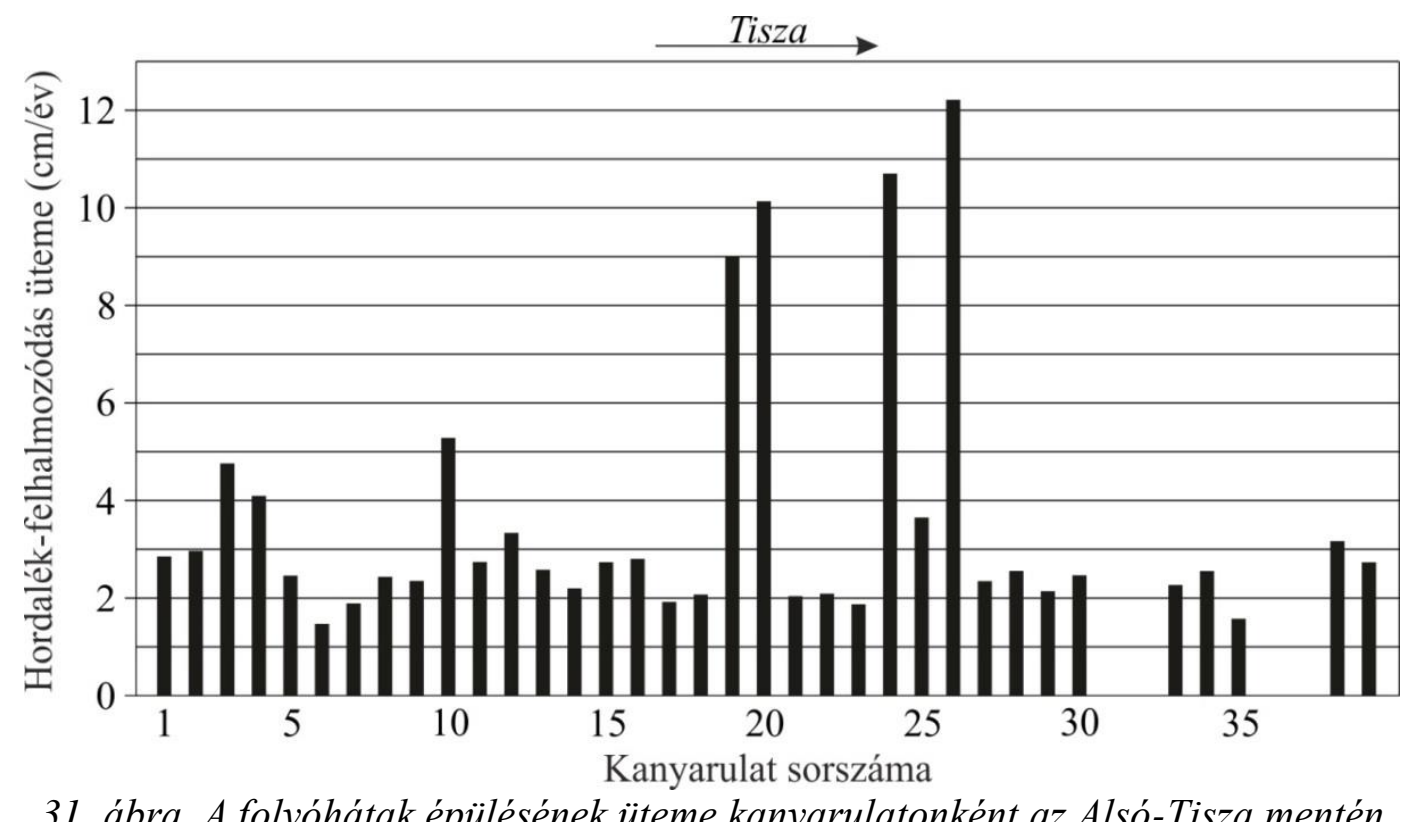

\subsubsection{A folyóhátak magasságát befolyásoló tényezők}

\section{A) A görbületi sugár és a hullámtér-szélesség hatása a folyóhátak magasságára}

Az eredményeim arra utalnak, hogy a folyóhátak relatív magassága kapcsolatot mutat a kanyarulatok fejlettségével, görbületi sugarával, illetve a hullámtér szélességével. Mivel a görbületi sugár hatása alapvetően meghatározza a kanyarulat mentén a centrifugális erő nagyságát (Hudson és Heitmuller 2003), így befolyásolja, hogy árvízkor a víz és a vele együtt szállított hordalék milyen távolságig jut el a hullámtéren. Ezért jelentős eltérések vannak a különböző fejlettségü kanyarulatok mentén fejlödő formák méreteiben, hiszen a különböző fejlettségi csoportok eltérő görbületi sugárral rendelkeznek. Azonban az árvíz áramlási viszonyait, és ezáltal a hordalék mozgását számos szakaszon befolyásolják a hullámtér szélességi viszonyai (pl. keskeny-e a hullámtér, vagy folyásirányban tágul-e). Ezért a folyóhátak méreteire gyakorolt hatásuk meghatározó lehet, és nagyon szük szakaszokon felülírhatják a görbületi sugár hatását. Ebből adódóan a két tényező hatását egyszerre elemzem.

Az ál-és fejletlen kanyarulatok mentén átlagosan 3,9 m magas (3-4,5 m) folyóhátak fejlődtek. A folyóhátak magassága és a kanyarulatok görbületi sugara $\left(R_{c}=515-3305 \mathrm{~m}\right)$ között elhanyagolható a kapcsolat $\left(\mathrm{R}^{2}=0,16\right)$, ugyanis a kisebb vagy nagyobb görbületi sugárral rendelkező kanyarulatok mentén egyaránt megfigyelhetők alacsonyabb és magasabb folyóhátak (32a. ábra). A kisebb görbületi sugarú $\left(\mathrm{R}_{\mathrm{c}}=865-1033 \mathrm{~m}\right)$ kanyarulatok mentén például 3,3-4,5 m magas folyóhátak épültek, míg a legnagyobb $\left(R_{c}=3305 \mathrm{~m}\right)$ görbületi sugarú kanyarulat külső ívén 4,4 m magas folyóhát formálódott. Véleményem szerint a kapcsolat hiányának oka egyrészt a nagy görbületi sugárban keresendő, ugyanis a legnagyobb $R_{c}$-vel az ál-és fejletlen kanyarulatok rendelkeznek, így az ebből adódó centrifugális erő nagysága kicsi, ezért árvíz idején a víz és a hordalék kisebb erővel áramlik ki a hullámtérre. Másrészt meghatározó lehet a hullámtér szélességének hatása is, ugyanis ezen kanyarulatok esetében a folyóhátak magassága elsősorban ezzel a paraméterrel mutat némileg szorosabb kapcsolatot $\left(\mathrm{R}^{2}=0,45 ; 32 b\right.$. ábra $)$, tehát minél szükebb a hullámtér, a kialakuló folyóhát annál magasabb. Az ál-és fejletlen kanyarulatok mentén az adott oldali hullámtér szélessége, tehát azon az oldalon, ahol a folyóhát fejlödik, átlagosan 340 m (50-1400 m). Két kanyarulat kivételével (12 és 25 . sz. kanyarulatok) a hullámtér mindenhol 750 m-nél szükebb, ráadásul a kanyarulat $60 \%$-a mentén szükebb, mint $200 \mathrm{~m}$. Úgy vélem, hogy ha a kanyarulatok görbületi sugarának lenne is valamilyen mértékü hatása a folyóhátak magasságára, ez nem bizonyítható, hiszen a kanyarulatok többségét övező rendkívül szük hullámtér felülírja a görbületi sugár hatását. 

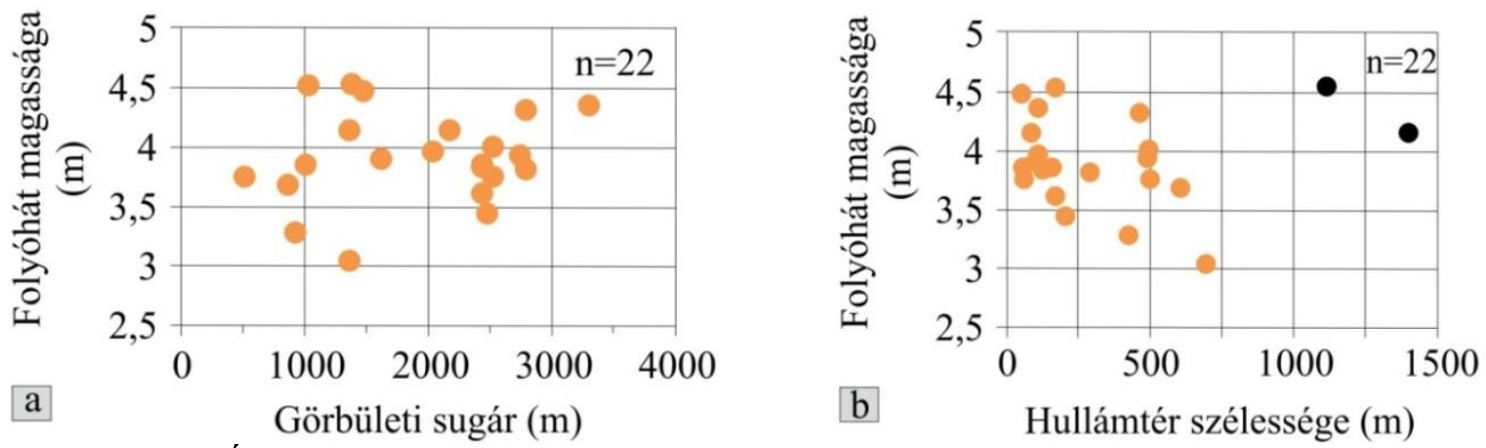

32. ábra. Ál-és fejletlen kanyarulatok mentén a folyóhátak magassága és a kanyarulatok görbületi sugara (a), valamint a hullámtér szélessége (b) közötti kapcsolat. A fekete pöttyök azokat a folyóhátakat jelölik, amelyek magasságát nem a hullámtér szélessége, hanem a holtágak végeinél lévő alacsonyabb térszín befolyásolja

Az előbb említett két kanyarulat (12 és 25 . sz. kanyarulatok) mentén a hullámtér széles (1400 és $1115 \mathrm{~m}$ ), és a kialakult folyóhátak is magasak $(4,1$ és 4,5 m). Azonban itt a formák intenzív épülése speciális okokra vezethető vissza: ez a két kanyarulat a szabályozások során történt két kanyarulat-átvágás eredményeként kialakított új mederszakasz mentén indult fejlődésnek, a levágott és az új meder határán. A kanyarulatok folyóhát formái pedig a két holtágat (Sulymos I. és a Mártélyi Holt Tisza) az aktív medertől elválasztó, intenzív hordalékfelhalmozódással rendelkező hordalékdugón (malágy) fejlődnek egy keskeny sávban. Ezek a holtágak napjainkban is egy mélyebb mederrészlettel kapcsolódnak az élő Tiszához. Ebben a mederrészletben egy mesterséges fok vezeti árvizekkor a vizet a hullámtér belsőbb részei felé. Ebben a viszonylag szük és mélyfekvésü térben a kiáramló víz építette a malágyot (a holtágat eltömő hordalékdugót), ami kimondottan a partél sávjában magas. Ugyanakkor ennek a keskeny taréj-szerü folyóhátnak a magassága folyásirányban fokozatosan nő, hiszen a holtág medre és az aktív partél között egyre szükebb tér áll rendelkezésre az akkumulációhoz (33. ábra).
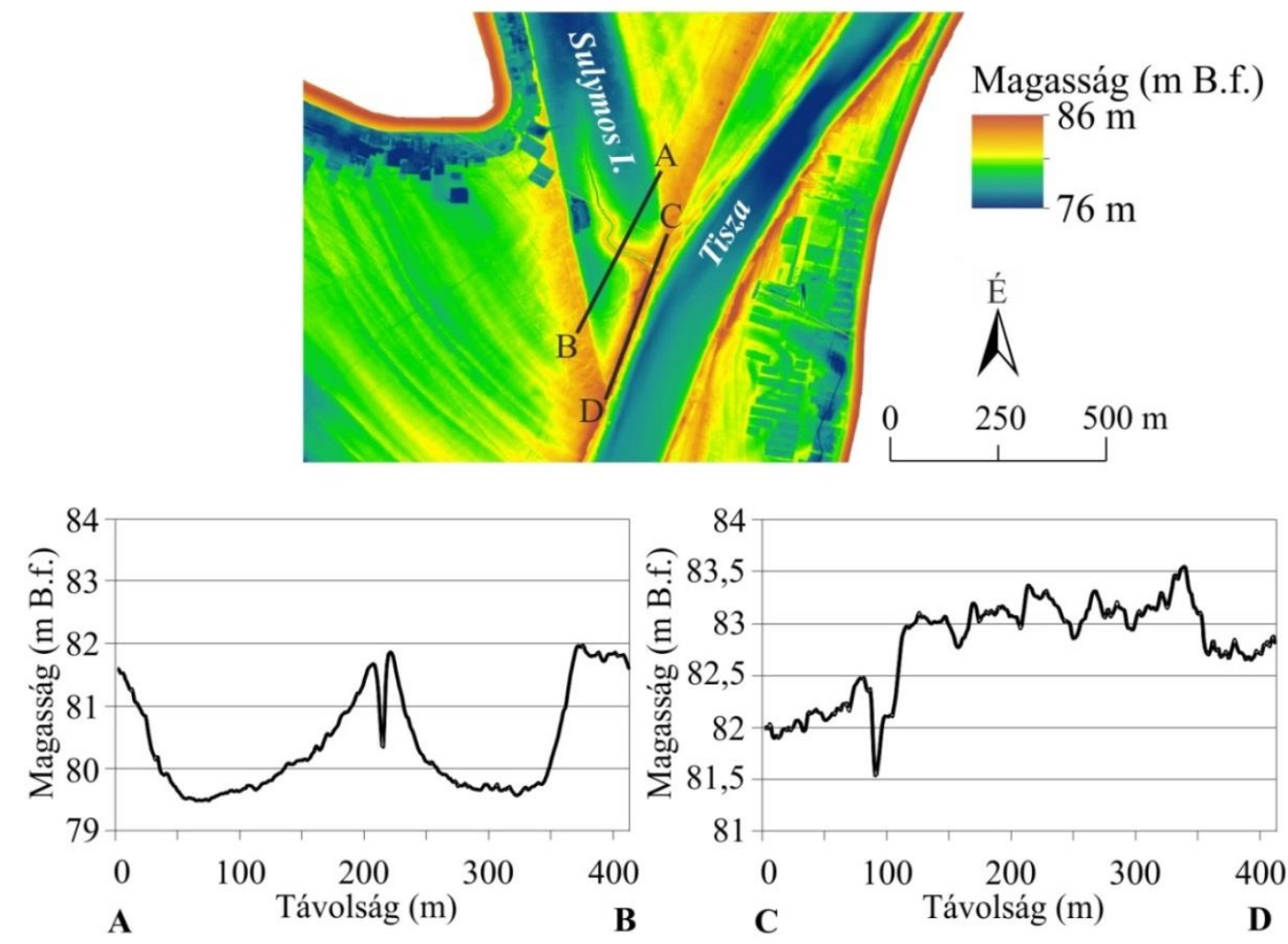

33. ábra. Egy speciális eset, amikor a folyóhát szélességét és magasságát nem a hullámtér szélessége, hanem a holtágak végeinél lévö alacsonyabb térszín (A-B metszet), illetve a holtág és az aktív meder csatlakozásánál az egyre szükebbé váló hely (C-D metszet) befolyásolja 
A fejlett és érett kanyarulatok csoportja esetén azonban az előzőtől eltérő kapcsolatok alakultak ki, ugyanis a kanyarulatok felénél kimutatható a görbületi sugár és a folyóhátak magassága közötti kapcsolat, míg a kanyarulatok másik fele esetében a formák a hullámtér szélességével mutatnak összefüggést. Előbbi kanyarulatoknál a folyóhátak magassága és a görbületi sugár között fordított arányosság van $\left(\mathrm{R}^{2}=0,86\right)$, tehát kis görbületi sugarú kanyarulatok mentén magasabb formák alakultak ki (34a. ábra). Ezt jól mutatja, hogy a csoportba tartozó legkisebb görbületi sugarú $\left(\mathrm{R}_{\mathrm{c}}=150 \mathrm{~m}\right)$ kanyarulat külső ívén $4,9 \mathrm{~m}$ a folyóhát magassága, míg a 860 m-es görbületi sugarú kanyarulatok mentén csupán 1,8-3,3 m magasak a folyóhátak. Ennek oka, hogy a kis görbületi sugár miatt nagyobb a kanyarulaton belül a centrifugális erő, így árvizek alkalmával a víz és vele együtt a hordalék is nagy erővel jut ki a hullámtérre (Fiala 2002, Sándor 2011). Mivel ráadásul ezen kanyarulatok mindegyike széles $(\geq 200 \mathrm{~m})$ hullámtéri szakaszokon található, ezért úgy vélem, hogy elegendő hely áll rendelkezésre ahhoz, hogy a görbületi sugár hatása érvényesüljön. Ezek a kanyarulatok kizárólag a Mártélyi- holtágtól felvízi irányban helyezkednek el, ugyanis ettől délre a meder kanyargóssága jóval kisebb és a hullámtér is egységesen szük.

A fejlett és érett kanyarulatok másik felében a folyóhátak magassága a hullámtér szélességével mutat gyenge kapcsolatot (34b. ábra). A két paraméter között fordított arányosság van $\left(\mathrm{R}^{2}=0,44\right)$, tehát szükebb hullámtéren magasabb, szélesebb hullámtéren pedig alacsonyabb formák alakulnak ki. Például 75 m széles hullámtéren a forma magassága 4,4 m, míg $770 \mathrm{~m}$ széles hullámtéren 3,2 m magas folyóhát formálódott.

A fejlett és érett kanyarulatokat elemezve megállapítható, hogy a szélesebb $(\geq 200 \mathrm{~m})$ hullámtéri szakaszokon elegendő hely áll rendelkezésre ahhoz, hogy a folyóhátak magasságát befolyásolja a kanyarulatok görbületi sugara, hiszen a kis $\mathrm{R}_{\mathrm{c}}$ miatt nagyobb erövel kiöntő víz nagyobb mennyiségü hordalék felhalmozódását teszi lehetővé a kanyarulat külső ívén. Ugyanakkor azokon a szakaszokon ahol a hullámtér szük, illetve a kanyarulat görbületi sugara pedig nagy, ott a hullámtér szélessége a meghatározóbb.
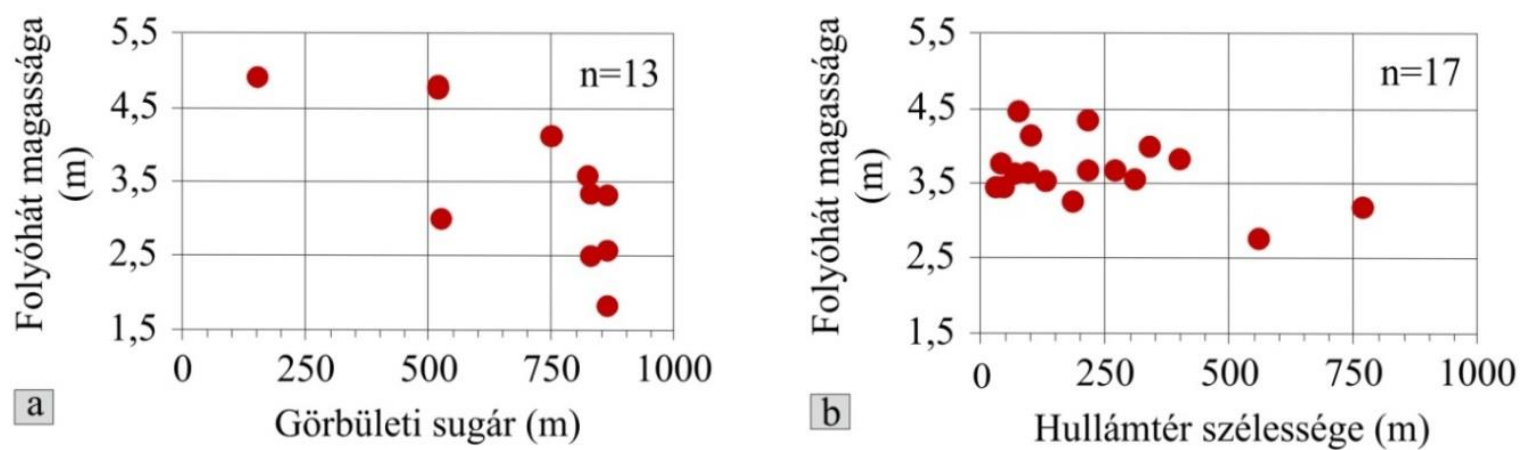

34. ábra. Fejlett és érett kanyarulatok mentén a folyóhátak magassága és a kanyarulatok görbületi sugara (a), valamint a hullámtér szélessége (b) közötti kapcsolat

\section{B) A partbiztositások hatása a folyóhátak magasságára}

Az Alsó-Tisza mentén a kanyarulatok 67\%-a partbiztosított, ráadásul ezek gyakorlatilag a folyóhátak mentén húzódnak, ezért fontosnak tartottam megvizsgálni, hogy a kanyarulatok külső ívén megépített partbiztosítások, illetve azok hiánya milyen hatást gyakorol a folyóhátak magasságára. Mivel ezek a kőrakatok a külső ív eróziójának megállását okozzák (Kesel 2003, Klasz et al. 2014), ezért általuk a folyóhátak épülése is módosulhat. Ezt a korábbiakhoz hasonlóan a kanyarulatok két csoportjára, az ál-és fejletlen, valamint a fejlett és érett kanyarulatokra vonatkozóan vizsgáltam meg.

Eredményeim szerint mindkét kanyarulati csoportban a partbiztosított szakaszokon fejlődő folyóhátak némileg magasabbak (35. ábra), hiszen az ál-és fejletlen kanyarulatok mentén a partbiztosított kanyarulatokban a formák átlagmagassága 4,1 m, a kőrakatok nélküli szakaszokon pedig 3,8 m. A biztosított fejlett és érett kanyarulatok mentén a folyóhátak átlagmagassága 3,7 m, 
míg a partbiztosítás nélküli szakaszokon 3,5 m. Tehát a partbiztosított kanyarulatok mentén átlagosan 0,2-0,3 m-rel magasabbnak adódik a folyóhátak magassága. Azonban bár ez a különbség egyértelmü, de mértéke a mérés hibahatárán belül esik, így véleményem szerint nem jelenthető ki biztosan, hogy a partbiztosítással rendelkező kanyarulatok külső ívén magasabb folyóhátak fejlődnének.

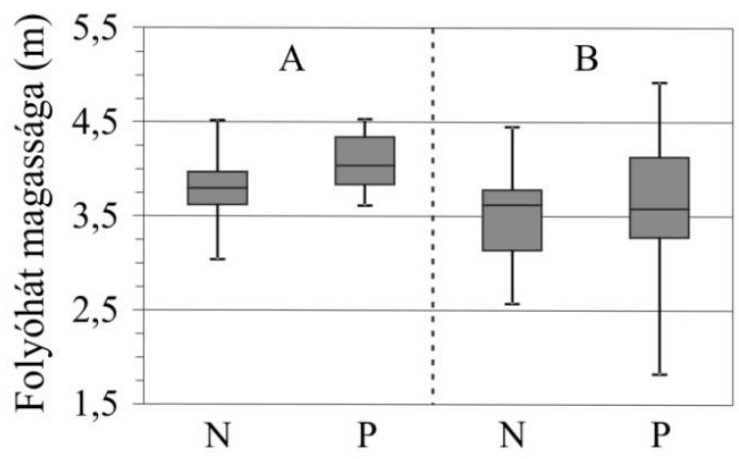

35. ábra. A folyóhátak magasságának alakulása ál-és fejletlen (A), valamint fejlett és érett (B) kanyarulatok mentén a partbiztositás nélküli $(N)$ és partbiztositott $(P)$ szakaszokon

\subsubsection{A folyóhátak szélességét befolyásoló tényezők}

\section{A) A folyóhát magassága és szélessége közötti kapcsolat}

A folyóhátak szélességi viszonyait befolyásoló tényezők vizsgálata során elöször azt elemeztem, hogy a különbözö kanyarulati csoportokon belül a folyóhátak szélessége és magassága között milyen kapcsolat áll fenn (36. ábra). Ennek vizsgálata véleményem szerint arra világít rá, hogy az egyes formák méretét ugyanazon tényező ugyanolyan mértékben határozza-e meg. Úgy vélem ugyanis, hogy ha a formák alaktani tulajdonságait ugyanaz a tényező és hasonló mértékben befolyásolná, akkor a folyóhátak magassága és szélessége között szignifikáns kapcsolatnak kellene fennállnia.

Az ál- és fejletlen kanyarulatok mentén azt tapasztalható, hogy a kialakult folyóhátak jellemzően magasak (3-4,5 m), azonban keskenyek (50-210 m). A két paraméter közötti korrelációs együttható $\mathrm{R}^{2}=0,49$, a két változó közötti kapcsolat pedig azt mutatja, hogy a formák magasodásával azok egyre keskenyebbé válnak. Az érett és fejlett kanyarulatok mentén is hasonló, bár némileg gyengébb korreláció figyelhető meg a formák magassága és szélessége között $\left(\mathrm{R}^{2}=0,47\right)$, továbbá a két paraméter közötti kapcsolat iránya más, mint az ál- és fejlett kanyarulatok mentén. Az érett és fejlett kanyarulatok mentén ugyanis minél magasabb egy folyóhát, a szélessége is annál nagyobb. Mindkét kanyarulati csoport esetében a formák magassága és szélessége közötti gyengébb korreláció azt sugallja, hogy a formák magasságát és szélességét különböző tényezők befolyásolják és eltérő mértékben.
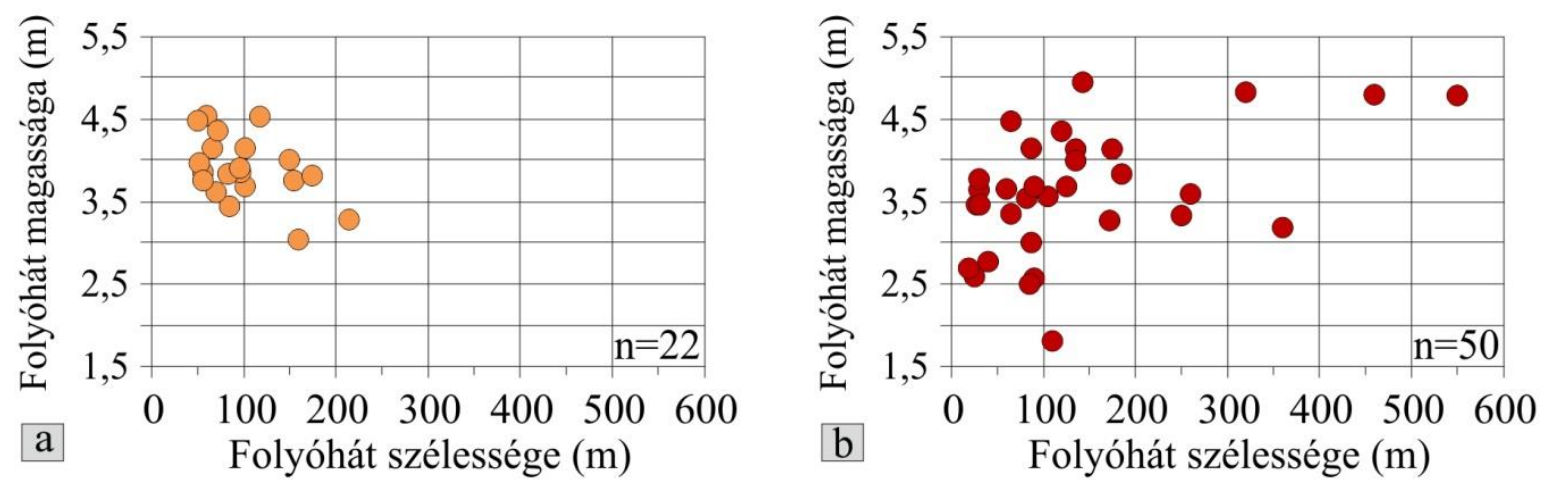

36. ábra. A folyóhátak magassága és szélessége közötti kapcsolat az ál-és fejletlen (a), illetve a fejlett és érett (b) kanyarulatok mentén 


\section{B) A görbületi sugár és a hullámtér-szélesség hatása a folyóhátak szélességére}

Az előző, a folyóhátak magasságát befolyásoló tényezőket tárgyaló fejezetben a kanyarulatok görbületi sugarának és a hullámtér szélességének hatását együtt vizsgáltam, mivel az utóbbi számos szakaszon felülírja a görbületi sugár hatását. Ezért a folyóhátak szélességét befolyásoló tényezők kapcsán is ezen két paraméter hatását együtt elemzem.

Az ál-és fejletlen kanyarulatok mentén a formák magasságához hasonlóan, a szélesség és a görbületi sugár között nincs egyértelmü kapcsolat $\left(\mathrm{R}^{2}=0,36\right)$, mivel a különböző görbületi sugárral rendelkező kanyarulatok mentén nagyon változatos szélességü formák alakultak ki (37a. ábra). A folyóhátak szélességét azonban meghatározza a hullámtér szélessége $\left(\mathrm{R}^{2}=0,65\right)$, hiszen minél szükebb hely áll rendelkezésre a formák kialakulásához, azok annál keskenyebbek (37b. ábra). Igen szük, mindössze 50-60 m széles hullámtéren csupán 50-55 m széles formák képződtek, tehát a folyóhátak egészen a gát lábáig elérnek, bár azt nem érik el, mert közöttük egy nagyobb vízsebességü áramlási zóna található Sándor (2011) mérései szerint. Szélesebb, 400-500 m széles hullámtéren pedig 310-360 m széles formák is megfigyelhetők. Néhány kanyarulat kivételt képez (2.,12., 17. és 25. számú kanyarulatok), amelyeknél megfigyelhető, hogy a széles (> $500 \mathrm{~m})$ hullámtér ellenére viszonylag keskeny $(<$ $150 \mathrm{~m}$ ) folyóhátak formálódtak. Ezekben az esetekben a folyóhát mélyedéseket tölt fel, a 12. 17. és 25. sz. kanyarulatok esetében a Sulymos I., Osztorai és a Mártélyi Holt Tisza holtágainak végét, míg a 2 . sz. kanyarulat esetében a gát lábánál lévő kubikgödröt. A mélyedésekben a forma eredeti szélességét nem lehet lemérni, mivel először a negatív formát kell a folyóhátnak feltöltenie ahhoz, hogy tovább tudjon terjeszkedni a hullámtér belsőbb területei felé. Ezért itt csak azt a keskeny, taréj-szerü forma szélességét mértem le, ami közvetlenül a pertél mellett található, amelynek fejlődését nem a hullámtér szélessége, hanem a negatív forma nagysága befolyásolja.

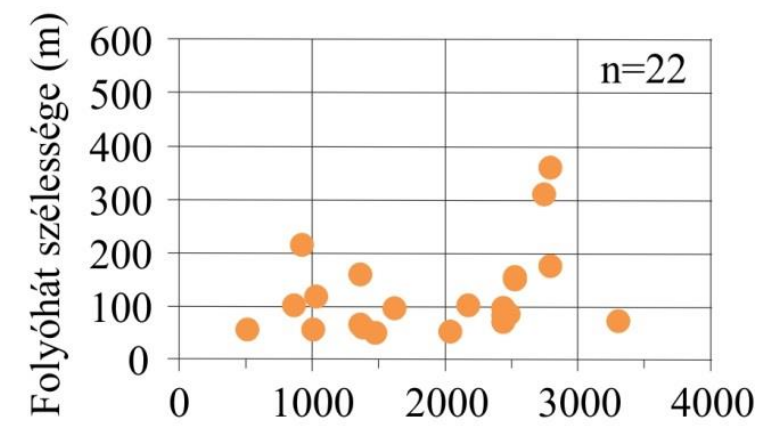

a

Görbületi sugár (m)

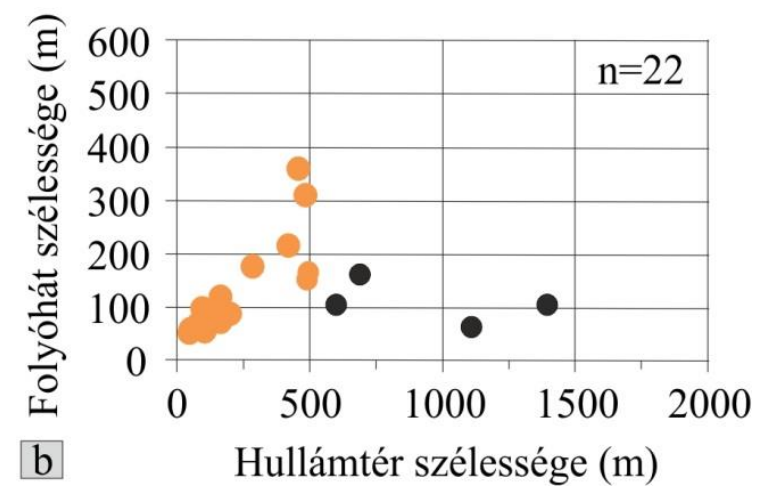

37. ábra. A folyóhátak szélessége és a kanyarulatok görbületi sugara (a), valamint a

hullámtér szélessége (b) közötti kapcsolat ál-és fejletlen kanyarulatok mentén. A fekete pöttyök azokat a folyóhátakat jelölik, amelyek szélességét nem a hullámtér szélessége, hanem

a holtágak végeinél lévö alacsonyabb térszín vagy pedig a kubikgödrök befolyásolják

A fejlett és érett kanyarulatok mentén formálódó folyóhátak nem voltak szétválogathatók aszerint, hogy szélességüket a kanyarulatok görbületi sugara vagy a hullámtér szélessége határozza-e meg, mint ahogy ez a kettéosztás a folyóhátak magasságánál elvégezhető volt. Ennek oka, hogy ugyanazon csoportok elemzése esetén, mint amelyeket a folyóhátak magasságánál meghatároztam, a görbületi sugár és a formák szélessége között nem fedezhető fel kapcsolat. Ebből adódóan az összes fejlett és érett kanyarulat mentén kialakult formát egyszerre vizsgáltam. Eredményeim szerint csak az 500 m-nél nagyobb görbületi sugárral rendelkező kanyarulatok mentén van gyenge kapcsolat $\left(R^{2}=0,5\right)$ a folyóhátak szélessége és a görbületi sugár között, hiszen ezen esetekben a görbületi sugár növekedésével a formák szélessége csökken (38a. ábra). Ezt tükrözi, hogy az 520-525 m-es görbületi sugarú kanyarulatok mentén a folyóhátak átlagszélessége 295 m (60-550 m), míg a legnagyobb 1860 
m-es $R_{\mathrm{c}}$-vel rendelkező kanyarulat mentén ez csupán átlagosan $140 \mathrm{~m}$ (felvízi részen $90 \mathrm{~m}$, míg a kanyarulat alsó harmadában $185 \mathrm{~m}$ ). Az Rc $\leq 500 \mathrm{~m}$ kanyarulatok esetében a formák átlagszélessége $125 \mathrm{~m}$. Ezen kanyarulatok külső ívén azonban a hullámtér jellemzően 200 mnél szükebb, így akár szélesebb folyóhátak is kialakulhatnának, viszont valamilyen egyéb tényező ezt megakadályozza.

A folyóhátak szélessége azonban az ál- és fejletlen kanyarulatokhoz hasonlóan határozott $\left(\mathrm{R}^{2}=0,65\right)$ fordított arányosságot mutat a hullámtér szélességével $(38 b$. ábra $)$.

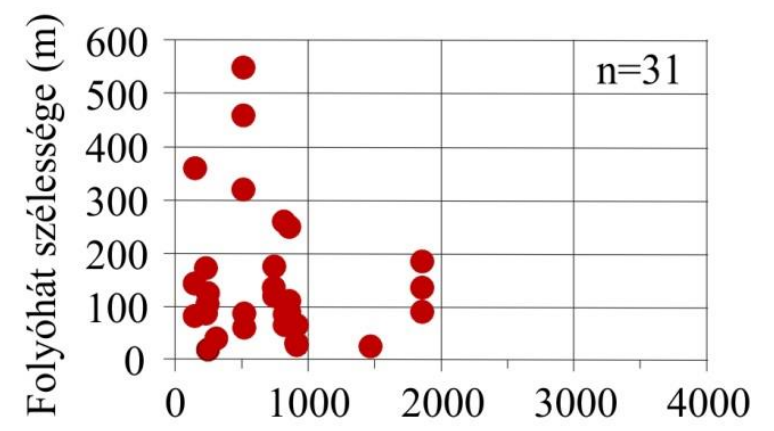

a b

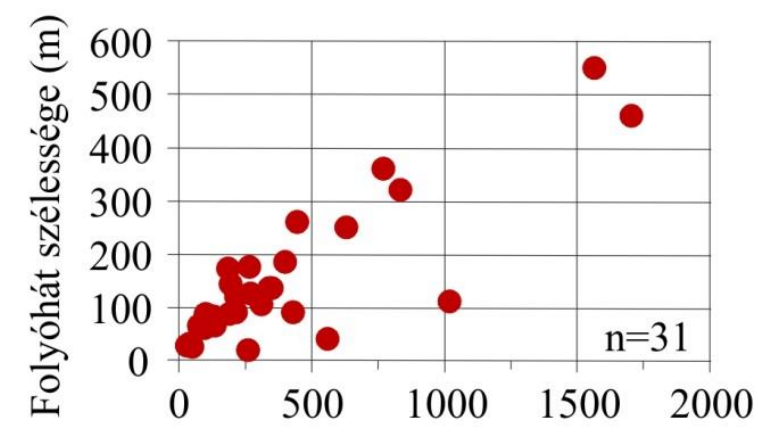

Hullámtér szélessége (m)

38. ábra. A folyóhátak szélessége és a kanyarulatok görbületi sugara (a), valamint a hullámtér szélessége (b) közötti kapcsolat fejlett és érett kanyarulatok mentén

\section{C) A folyóhátak kora és szélessége közötti kapcsolat}

Az Alsó-Tisza mentén fejlődő folyóhátak igen változatos korúak, hiszen egyes formák már a szabályozások előtt is léteztek, így már legalább 180 évesek, míg vannak igen fiatal, mindössze 40 éve fejlődő formák. A folyóhátak fejlődésére tehát eltérő hosszúságú idő állt rendelkezésre, amely a szélességi viszonyaikban is tükröződhet (39. ábra). Emellett jelentös különbségek fedezhetők fel a különböző fejlettségü kanyarulatok mentén is, amely elsősorban a legidősebb formákat érinti.

A legalább 180 éves folyóhátak átlagos szélessége az ál- és fejletlen kanyarulatok mentén $150 \mathrm{~m}(50-360 \mathrm{~m})$, míg a fejlett és érett kanyarulatok esetében $160 \mathrm{~m}(40-550 \mathrm{~m})$. Az, hogy az utóbbi csoportban nagyobb a formák átlagos szélessége, a kanyarulatok kisebb görbületi sugarával magyarázható, hiszen az ezzel járó nagyobb centrifugális erő miatt a hordalék nagyobb távolságba képes eljutni a hullámtéren árvíz idején. Ezen legidősebb formák szélességi adatai azonban meglehetősen nagy szórást mutatnak, amely véleményem szerint összefüggésbe hozható az árvízvédelmi töltések megépítésével, hiszen az erősen leszükített hullámtéren ugyanazon idős forma sokkal kisebb helyen kényszerült továbbfejlődni.

A fiatalabb formák ( $<180$ év) esetében megfigyelhető, hogy minél rövidebb ideje fejlődik a folyóhát, annál keskenyebb. A legalább 120 éve fejlődő folyóhátak átlagosan $115 \mathrm{~m}$ (60-310 m) szélesek, míg a legalább 80 éves formák átlagosan 96 m $(65-150 \mathrm{~m})$ szélesek, míg a legfiatalabb, 40 éves folyóhátak átlagszélessége 63 m (30-120 m).

Tehát a formák fejlődésének előrehaladtával egyre szélesebbé válnak, hiszen az árvizek alkalmával egyre több hordalék halmozódik fel a felszínükön. Ez a megállapítás azonban csupán azokra a folyóhátakra igaz, amelyek fejlődésére elegendő hely áll a rendelkezésre, tehát fejlődésüket a hullámtér szélessége nem korlátozza. 


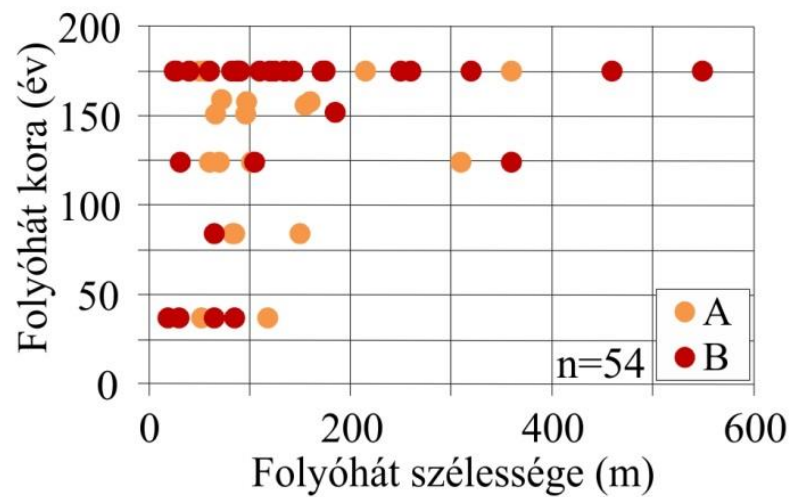

39. ábra. A folyóhátak kora és szélessége közötti kapcsolat a különbözö fejlettségü

kanyarulatok mentén. ,A: ál- és fejletlen kanyarulatok, B: fejlett és érett kanyarulatok

\subsubsection{A folyóhátak épülésének ütemét befolyásoló tényezők}

\section{A) A folyóhátak kora és épülésük üteme közötti kapcsolat}

Az ál-és fejletlen kanyarulatok, illetve a fejlett és érett kanyarulatok alapvetően különböznek abban, hogy a külső ívükön fejlődő folyóhátak milyen hosszú ideje épülnek. Mivel az ál- és fejletlen kanyarulatok a mederrendezés során kialakult új folyószakaszokon indultak fejlődésnek, így ezek többsége mentén a folyóhátak legfeljebb 180 éve fejlődnek. Ezzel szemben a fejlett és érett kanyarulatok mentén kialakult folyóhátak egy része már a szabályozási munkálatok előtt is létezett, így épülésük legalább 180 éve tart.

A két kanyarulati csoport mentén a folyóhátak épülése némileg eltérö ütemben zajlik, azonban mindkettő esetében megfigyelhető a hordalék-felhalmozódás ütemének gyorsulása (40. ábra). Az ál- és fejletlen kanyarulatok mentén a legidősebb, legalább 180 éves folyóhátak épülésének üteme átlagosan $22 \mathrm{~mm} / \mathrm{év}$ (19-26 mm/év), míg a legfiatalabb formák átlagosan 107-122 mm/év ütemben fejlödnek. A fejlett és érett kanyarulatok mentén is hasonló a változás: a legidősebb folyóhátak épülésének átlagos üteme $21 \mathrm{~mm} / \mathrm{év}(10-28 \mathrm{~mm} / \mathrm{e} v)$, a legfiatalabbaké pedig átlagosan $83 \mathrm{~mm} / \mathrm{e} v(67-101 \mathrm{~mm} / \mathrm{év})$.

A hordalék-felhalmozódás ütemének gyorsulását számos tényező okozhatja. Kiemelt hatása lehet az egyre sürübbé váló part menti növényzetnek, hiszen eredményeim szerint a hullámtér növényzeti érdessége a 18. század vége óta közel ötszörösére növekedett, amelyet fokoz az invazív gyalogakác nagyarányú jelenléte. A felhalmozódás ütemét továbbá jelentős mértékben növelheti az árvizek magasságának és tartósságának növekedése is (Sándor és Kiss 2007, Sándor 2011), amely nagyobb mennyiségü hordalék felhalmozódását teszi lehetővé a hullámtéren. Ráadásul az egyre szükebb mederből kilépő árvizek munkavégző képessége is egyre nagyobb (Kiss 2014), ami szintén elősegíti, hogy több hordalék rakódjon le a part menti sávban.

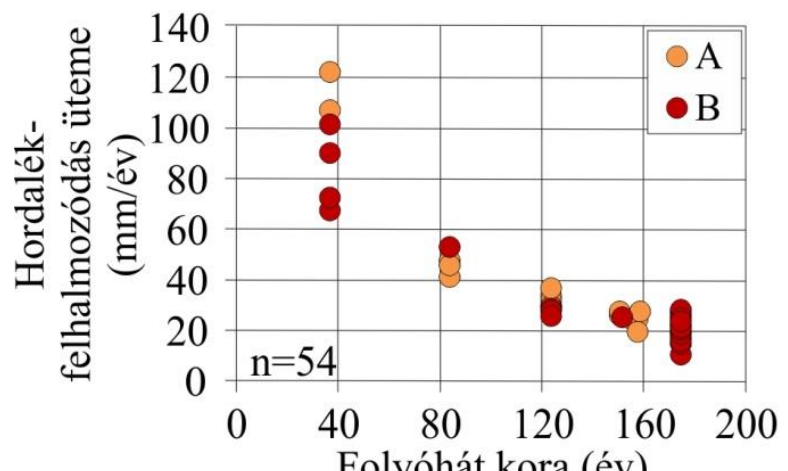

Folyóhát kora (év)

40. ábra. A folyóhátak kora és épülésük ütemének kapcsolata különbözö fejlettségü kanyarulatok mentén (A: ál- és fejletlen kanyarulatok, B: fejlett és érett kanyarulatok) 


\section{B) A sodorvonal helyzetének hatása a folyóhát-épülés ütemére}

A folyóhátak épülésének üteme mindkét kanyarulati csoport esetében a sodorvonal parttól való távolságával mutatja a legszorosabb kapcsolatot $\left(\mathrm{R}^{2}=0,59\right.$ és $\left.\mathrm{R}^{2}=0,58\right)$. A két paraméter közötti egyenes arányosság van, azaz minél közelebb helyezkedik el a sodorvonal a kanyarulat külső ívéhez, a formák annál lassabb ütemben fejlődnek (4lab. ábra). Véleményem szerint ez azzal magyarázható, hogy a külső ívhez közel elhelyezkedő sodorvonal lehetővé teszi árvízkor a part menti sáv erózióját (Uddin és Rahman 2012), amely hatására a folyóhát épülésének üteme lassabbnak adódik.
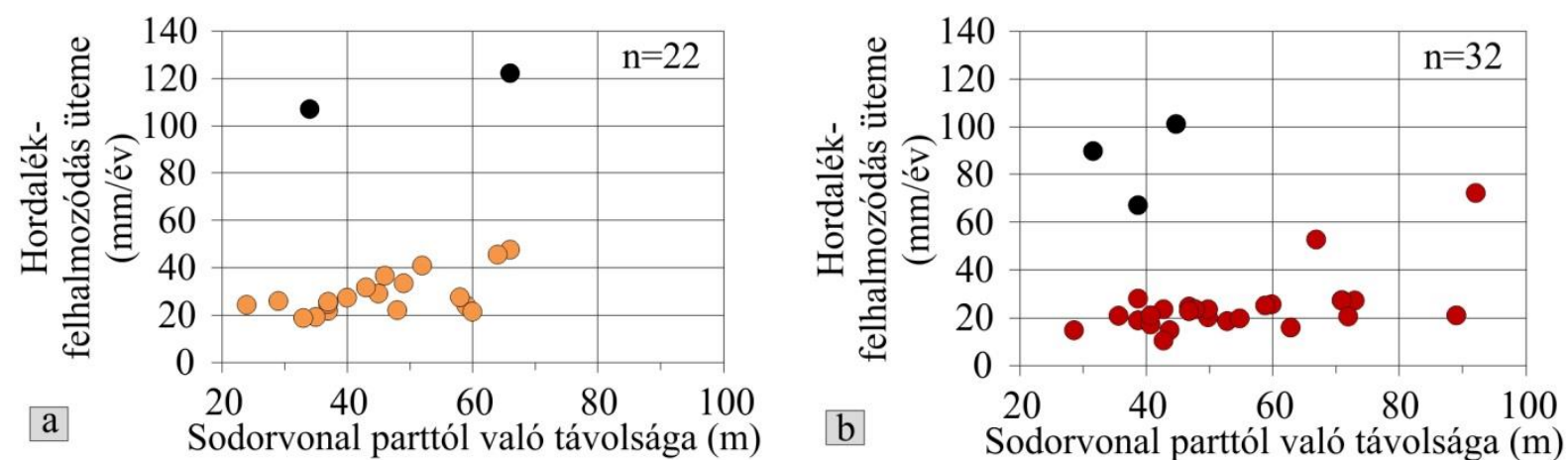

41. ábra. A folyóhát-épülés üteme a sodorvonal parttól való távolságának függvényében ál-és

fejletlen (a), illetve fejlett és érett kanyarulatok (b) mentén. A fekete pöttyök azokat a

folyóhátakat jelölik, amelyek épülésének ütemét nem a sodorvonal parttól való távolsága, hanem egyéb tényezők befolyásolják

\subsubsection{A folyóhátak fejlödését befolyásoló tényezők összevetése}

Eredményeim szerint a folyóhátak méretét (magasságát és szélességét) a kanyarulatok görbületi sugara és a hullámtér szélessége, míg a formák épülésének ütemét pedig a forma kora és a sodorvonal külső partéltől való távolsága határozza meg. Az egyes paraméterek közötti kapcsolatok azonban eltérnek a különböző fejlettségü (ál-és fejletlen, illetve fejlett és érett) kanyarulatok mentén (8. táblázat).

A kanyarulatok görbületi sugara eröteljesen befolyásolja a folyóhátak magasságát a fejlett és érett kanyarulatok mentén. Ez egyrészt összefüggésbe hozható ezen kanyarulatok kisebb görbületi sugarával, amely lehetővé teszi, hogy árvízkor nagyobb mennyiségü szállított hordalék halmozódhasson fel a hullámtéren, másrészt pedig az ezen kanyarulatok mentén jellemző szélesebb hullámtér lehetővé teszi a görbületi sugár hatásának érvényesülését. E két tényező hatásának kombinálódása a folyóhátak magassága és szélessége közötti kapcsolatban is tükröződik, hiszen a kis görbületi sugár és a széles hullámtér lehetővé teszi mind a formák magasodását és szélesedését is.

Az ál-és fejletlen kanyarulatok mentén azonban a görbületi sugár hatása gyengébb, amely kapcsolatban áll a nagy görbületi sugárból adódó kisebb centrifugális erővel, illetve az ezen kanyarulatok mentén jellemző szük hullámtéri szakaszokkal, amely megakadályozza a görbületi sugár hatásának érvényesülését. A folyóhátak szélességét ezzel szemben szinte kizárólag a hullámtér szélessége határozza meg. A formák magassága és szélessége közötti kapcsolat is mutatja a hullámtér szélességének dominánsabb hatását, hiszen ezen kanyarulati csoporton belül a magas folyóhátak elsősorban keskenyek.

A kanyarulatok külső ívén megépített partbiztosítások hatása a folyóhátak magasságára nem bizonyítható egyértelmüen. Bár a kőrakatokkal biztosított szakaszokon a folyóhátak átlagmagassága 0,2-0,3 m-rel nagyobb, mint a partbiztosítással nem rendelkezőké, a különbség azonban a mérés hibahatárán belül esik. 
A folyóhátak épülésének üteme a formák korával és a sodorvonal külső ívtől való távolságával áll a legszorosabb kapcsolatban. A legfiatalabb (legfeljebb 40 éves) formák átlagos épülésének üteme ( $83-115 \mathrm{~mm} / \mathrm{v}$ ) 4-5-ször gyorsabb, mint a legidösebb (> 180 éves) folyóhátaké (21-22 mm/év). Azokon a szakaszokon, ahol a sodorvonal a parthoz közel helyezkedik el, megteremtődik a lehetőség a part menti területek, így a folyóhátak eróziójára. Ennek eredményeképpen a formák fejlődésének átlagos sebessége lassabb, mint azokon a szakaszokon, ahol a sodorvonal távolabb helyezkedik el a parttól.

8. táblázat. A folyóhátak méretét és épülésük ütemét befolyásoló tényezök és azok hatásfoka (0: nincs kapcsolat, +: gyenge pozitív kapcsolat, ++: erös pozitív kapcsolat, -: gyenge negatív kapcsolat, - -: erös negatív kapcsolat)

\begin{tabular}{|l|c|c|c|c|c|c|}
\hline \multicolumn{1}{|c|}{$\begin{array}{c}\text { Befolyásoló } \\
\text { tényezól }\end{array}$} & \multicolumn{2}{|c|}{ Ás fejletlen kanyarulatok } & \multicolumn{3}{c|}{ Fejlett és érett kanyarulatok } \\
\hline & $\begin{array}{c}\text { Folyóhát } \\
\text { magassága }\end{array}$ & $\begin{array}{c}\text { Folyóhát } \\
\text { szélessége }\end{array}$ & $\begin{array}{c}\text { Folyóhát- } \\
\text { épülés } \\
\text { üteme }\end{array}$ & $\begin{array}{c}\text { Folyóhát } \\
\text { magassága }\end{array}$ & $\begin{array}{c}\text { Folyóhát } \\
\text { szélessége }\end{array}$ & $\begin{array}{c}\text { Folyóhát- } \\
\text { épülés } \\
\text { üteme }\end{array}$ \\
\hline $\begin{array}{l}\text { Görbületi } \\
\text { sugár }\end{array}$ & + & 0 & 0 & ++ & + & 0 \\
\hline $\begin{array}{l}\text { Hullámtér- } \\
\text { szélesség }\end{array}$ & ++ & ++ & 0 & ++ & ++ & 0 \\
\hline Partbiztosítás & + & 0 & 0 & + & 0 & 0 \\
\hline $\begin{array}{l}\text { Sodorvonal } \\
\text { távolsága }\end{array}$ & 0 & 0 & - & 0 & 0 & - \\
\hline $\begin{array}{l}\text { Épülés } \\
\text { hossza (kor) }\end{array}$ & 0 & 0 & -- & 0 & 0 & -- \\
\hline
\end{tabular}

\subsubsection{A folyóhátak és az árvizek magassága közötti kapcsolat}

A folyóhátak a hullámtér legmagasabb formái, ezért jelentős hatást gyakorolnak a hullámtér vízvezető képességére, hiszen a kanyarulatok külső ívén meghatározzák, hogy milyen magasságú árvíz képes kilépni adott ponton a hullámtérre, továbbá hatást gyakorolnak a mederből kilépő árhullám erejére és hordalékszállítására is.

Az Alsó-Tisza mentén nem figyelhető meg egy adott kanyarulaton belül a folyóhátak több generációja (kivéve a 22. számú Ányási-kanyarulatot) mint a Maros mentén (Kiss et al. 2018b), így csupán a folyóhátak jelenlegi magasságának árvízszintekre gyakorolt hatását tudtam megvizsgálni. Az elemzésekhez a mindszenti vízmérce vízállás adatait használtam fel, mert ezen a szakaszon a mellékfolyók (Körösök és a Maros) hatása kevésbé befolyásolja a vízállásokat, mint a szegedi és a csongrádi vízmércék esetében. A vízállás adatok alapján kiszámítottam, hogy a Mindszenttől felvízi és alvízi irányban elhelyezkedő kanyarulatok (1822. számú kanyarulatok) mentén a folyóhátak felszínét milyen magasságú és visszatérési idejü árvizek képesek elönteni, azaz milyen minimum magasságú árvizek szükségesek a hordaléklerakás megindulásához.

Eredményeim szerint a vizsgált folyóhátak felszínét a legalább 758-842 cm magas árhullámok képesek csak elönteni és építeni (42. ábra). A Mindszenttől felvízi irányban elhelyezkedő 18. számú kanyarulat mentén, a folyóháton a legalább $777 \mathrm{~cm}$ magas árhullám képes átbukni, a 19. sz. kanyarulat mentén a $758 \mathrm{~cm}$, a 20. kanyarulat mentén a $801 \mathrm{~cm}$, a 21 . sz. kanyarulat mentén pedig a legalább $805 \mathrm{~cm}$ magas vízállások képesek a folyóhátak felszínét magasítani. Az árvizek visszatérési idejét tekintve megállapítható, hogy az itt bemutatott folyóhátakat a 3,2-4,6 évente visszatérö árvizek képesek csak elönteni és hordalékukkal beborítani.

A 22. (Ányási-) kanyarulat némileg különbözik az előbb felsorolt kanyarulatoktól, hiszen középső harmadának külső ívén két különböző korú, de aktívan épülő folyóhát 
helyezkedik el. A közvetlenül a medret szegélyező forma $60 \mathrm{~cm}-r e l$ alacsonyabb, mint a medertől távolabb elhelyezkedő folyóhát. Ennek eredményeképpen az alacsonyabb formát a $749 \mathrm{~cm}$ magas árvizek már beborítják, míg a magasabbat csupán a legalább $805 \mathrm{~cm}$ magas árhullámok öntik el. Előbbit tehát a gyakoribb 2,9 évente visszatérő árvizek is elöntik, míg utóbbi csak a 4,6 évente visszatérö árvizek során kerül vízborítás alá. Ugyanezen kanyarulat alsó harmadában azonban nem alakult ki fiatalabb és alacsonyabb folyóhát, így ennek felszínét csupán a legalább $842 \mathrm{~cm}$ magas, azaz a 7,2 évente visszatérő vízállások képesek csak építeni.

A folyóhátak medertől távolabb eső részei ezzel szemben alacsonyabb vízállások esetén is épülhetnek, hiszen az alacsonyabb part menti területek (pl. fokok) mentén a kisebb vízállások is elöntik a hullámteret, amelyek hordalékukkal a folyóhátak alacsonyabb, medertől távolabb eső részeit is képesek építeni. Ugyanakkor ez a felhalmozódás merőben más módon történhet, más típusú hordalékkal, hiszen a partélen átbukó és a folyóhátat magasító árhullámok durvább szemcse-összetételü fenékhordalékot is lerakhatnak nagy vastagságban, míg a folyóhátak peremeit elöntő vizekből legfeljebb lassan ülepedhet le a lebegtetett hordalék egy hártyavékony réteg formájában (Sándor 2011).

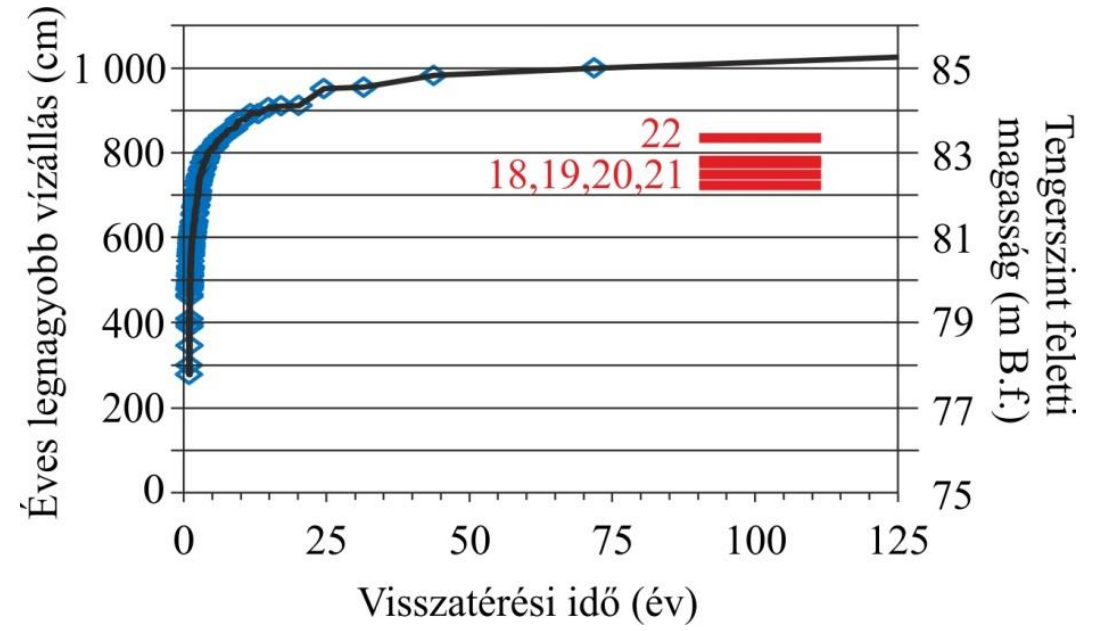

42. ábra. Az 1901 és 2016 között mért éves legnagyobb vizállások visszatérési ideje Mindszentnél a Gringorten-formula alapján számolva. Összehasonlitásképpen a vizmércétöl alvizi és felvízi irányban elhelyezkedö öt kanyarulat folyóhátainak magasságát is feltüntettem (piros vonal), a számok pedig a kanyarulatok sorszámát jelölik

\subsubsection{A folyóhátak szemcseösszetételi vizsgálata}

\section{A) A folyóhátak szemcseösszetételének térbeli jellemzöi}

Az Alsó-Tisza hullámterén a folyóhátak legfelső 5-10 cm-éből gyüjtött 25 minta eredményei azt mutatják, hogy a folyóhátak felszínén a legutóbbi árvíz (2013) alkalmával igen változatos szemcse-összetételü hordalék-felhalmozódás történt (43. ábra). A minták mindegyikében a homokfrakció $(>125 \mu \mathrm{m})$ és az iszap $(7,8-125 \mu \mathrm{m})$ dominál, hiszen a felszíni üledékekben a homok aránya átlagosan 39\%, az iszapé pedig átlagosan $49 \%$. Az agyagfrakció $(0,1-7,8 \mu \mathrm{m})$ aránya mindegyik minta esetében viszonylag kicsi, átlagosan $12 \%$ (4-36\%). Mivel árvizek alkalmával a folyóhátak felszínén elöször a folyó által szállított legdurvább hordalék, azaz a homok halmozódik fel legelöször, így ennek a szemcsefrakciónak a változása jól tükrözi a formákat formáló hidrológiai viszonyokban bekövetkező változásokat. Ezért a következőkben elsősorban a homokfrakció térbeli változását mutatom be részletesen, hiszen az iszap és az agyagfrakció arányának változása minden mintán belül komplementer módon, és közel ugyanolyan mértékben változik. 


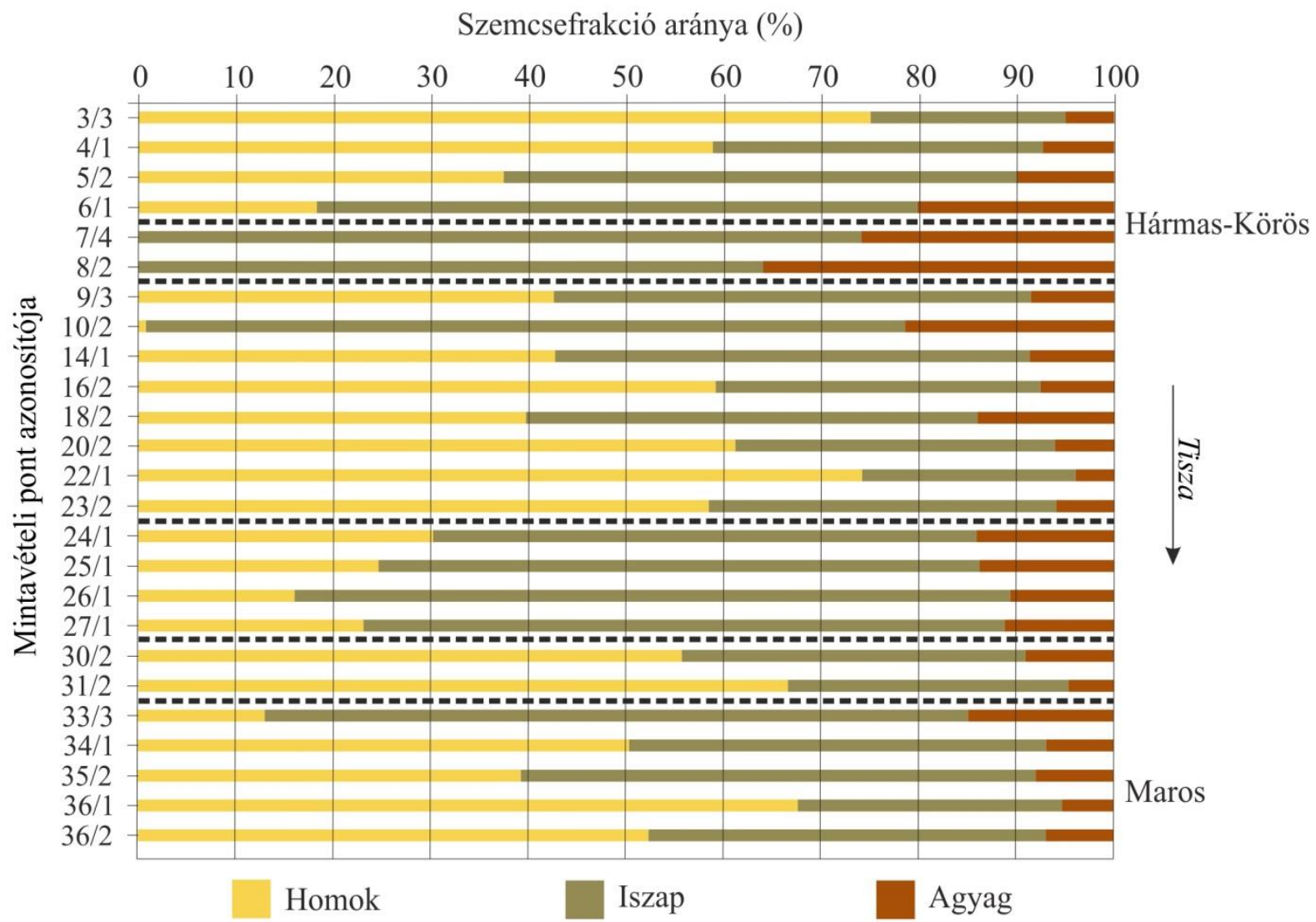

43. ábra. Az Alsó-Tisza menti folyóhátak felső 5-10 cm-éböl származó minták szemcseösszetételének folyásirányban történö változása

A mintaterület északi részén, egészen a Hármas-Körös torkolatáig az üledékekben lévő homok aránya fokozatosan csökken (75\%-ról 18,3\%-ra). Ezt követően (7-8. kanyarulatok) a minták nem tartalmaznak homokot, itt az üledékek legnagyobb részét iszap (átlagosan 68\%) alkotja. Ez alátámasztja azt a korábbi megállapításomat, miszerint a Hármas-Körös betorkollása befolyásolja a Tisza áramlási viszonyait és hordalékszállítását, annak ellenére, hogy a Körösökből viszonylag hordalékszegény víz érkezik. A 2013-as árvíz során (amikor a folyóhát felső rétegsora lerakódott) a Tiszán és a Körösökön is levonult árhullám. A torkolat feletti kanyarulatok azt mutatják, hogy a torkolat felé haladva a vízsebesség fokozatosan csökkent a visszaduzzasztás miatt, így egyre kevésbé homokos anyag rakódott le a hullámtérre, és közvetlenül a torkolat felett a pangó vízből nagy mennyiségü iszap és agyag ülepedett le. Ugyanakkor közvetlenül a torkolat alatt (7/4 és 8/2 minták) a Körösök vizének hordalékszegénysége miatt megnőtt a Tisza munkavégző-képessége, ami miatt a durvább hordalékszemeket tovább szállította, ezért csak az árhullám apadó ágában kezdődhetett meg az akkumuláció a folyóhát felszínén, így ott iszapos-agyagos lebegtetett rakódott le, ami magyarázza a hullámtéri feltöltődés mérsékeltebb mennyiségét is. Ez a hatás a 8. számú kanyarulatig ( $8 / 2$ minta), tehát a torkolattól számított $5 \mathrm{~km}$-es távolságig érvényesül, majd ez alatt újra megindul a homokos hordalék intenzívebb akkumulációja. Ezt jól mutatja az, hogy a 9. sz. kanyarulat mentén fejlödött folyóhát anyagában (9/3 minta) a homokfrakció aránya már $43 \%$.

A következő szakaszon (9. sz. kanyarulattól egészen a 23. sz. kanyarulat középső harmadáig) bár változó a folyóhátat felépítő anyag homoktartalma (1-59\%), de folyásirányban növekszik. A homoktartalom ingadozása összhangban lehet a hullámtér szélességével, ugyanis ezen a szakaszon a Tisza hullámterét számos szükület és tág öblözet tagolja, ráadásul ezen a szakaszon igen változatos fejlettségü és görbületi sugarú kanyarulatok alakultak ki. A 20. sz. és a 23. sz. kanyarulat között (20/2-23/2 minták) az üledékek homoktartalma ismét 
magasabb (58,5-74\%), és a 22. számú, Ányási-kanyarulat külső ívén fejlődő folyóhát (22/1 minta) anyaga tartalmazta a legtöbb homokot (74\%) az egész Alsó-Tisza mentén. Emellett ezen a három kanyarulat mentén halmozódik fel a leggyorsabb ütemben (75-104 mm/év) a hordalék a folyóhátak felszínén, amely megmagyarázza a homok nagy arányú jelenlétét az üledékekben. A felhalmozódás üteme és a felszíni üledékek homoktartalma között ugyanis kapcsolat fedezhető fel $\left(\mathrm{R}^{2}=0,53\right)$, hiszen minél gyorsabban épül egy folyóhát, a forma felszínén annál nagyobb mennyiségü homok halmozódhat fel (44. ábra), ami jelzi, hogy ezeken a helyeken a víz nagy sebességgel áramlik ki az árvizek áradó ágában az ártér felé. Így a folyóhátak felszínére főleg a fenéken szállított homok eljut, és itt jelentős mértékben hozzájárul a folyóhátak magasodásához.

Folyásirányban lefelé, egészen a 27. sz. kanyarulatig (24/1-27/1 minták) a folyóhátakat felépítő üledékek homoktartalma egységesen alacsony (16-30\%), mivel ez a szakasz a kanyarulat-átvágások következtében enyhén kanyargóssá vált és a nagy görbületi sugarú kanyarok mentén az ártérre kilépő víz energiája kisebb, tehát kevesebb homokanyag juthatott a partél sávjába. Ezzel szemben a 30-31. sz. kanyarulatok mentén nagy arányban (56-70\%) halmozódott fel homok, ami egyértelmüen ezen kanyarulatok kisebb görbületi sugarával magyarázható. Innentől (33/3 mintától) egészen a Maros torkolatáig a homokfrakció aránya csökken, bár nem olyan mértékben, mint a Körös-torkolat felé haladva, tehát a Maros visszaduzzasztó hatása kevésbé érvényesült a 2013-as árvíz során (ekkor csupán mederkitöltő vízszint fordult elö). Majd a Maros torkolata alatt (36. kanyar) a minták homoktartalma megnő, amely jól mutatja a Maros által szállított nagy mennyiségü durva hordalék hirtelen eséscsökkenés okozta felhalmozódását.

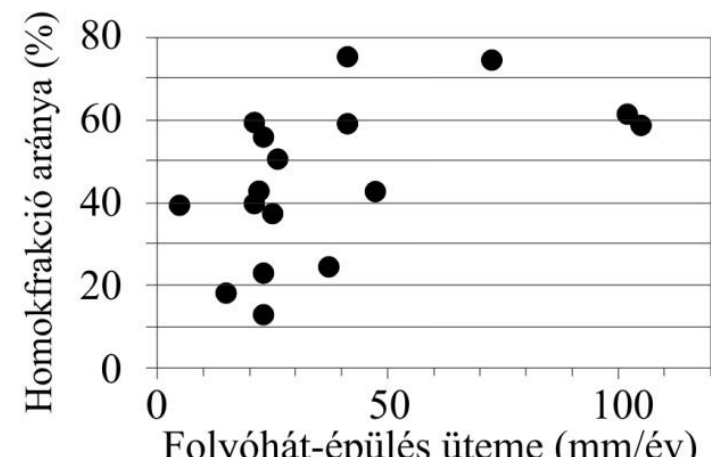

44. ábra. A megmintázott folyóhátak felső 5-10 cm-ében lévö homokfrakció aránya és a formák épülési üteme közötti kapcsolat

\section{B) A folyóhátak szemcseösszetételének időbeli változása}

A folyóhátak szemcse-összetételételének vizsgálatához mélységi fúrásokat is végeztünk, amelyből a folyóhátak épülésének körülményeire, és ezen körülmények változásaira lehet következtetni. Ehhez két folyóhátat mutatok be részletesebben, egy fiatalabb (legfeljebb 80 éve fejlődő) és egy idősebb (legalább 120 éve fejlődő) formát. Előbbit a 10/2-es, míg utóbbit a 20/2-es fúrásszelvény reprezentálja (45. ábra).

Mindkét folyóhát esetében sikerült lefúrni a hordalék-felhalmozódás megindulása előtti eltemetett paleo-talaj rétegig, amely magas iszap- és agyagtartalommal jellemezhetö, és a fúráskor a paleo-talaj elérését jelezte annak sötétebb színe és igen tömörödött szerkezete. A paleo-talaj mélysége azonban a két minta esetében eltérő mélységben található. Míg a 20. sz. kanyarulatnál lévő folyóhát évszázadok óta fejlődik, addig a 10. sz. kanyarulatnál lévő a mederszükülés következtében csak 1930 után kezdett fejlödni. Mindkét megmintázott folyóhátnál építettek partbiztosítást (a 10-es kanyarulatnál 1914-ben, a 20-as kanyarulatnál 1910-ben). 
A 10/2-es, fiatalabb minta esetében a paleo-talaj zónáját már 260-270 cm-es mélységben elértük, ahol az iszap aránya $68 \%$, az agyagé pedig $32 \%$. Az e feletti üledékrétegben $(200-260 \mathrm{~cm})$ továbbra is az iszap és az agyagfrakció dominál, a homok csupán egy $20 \mathrm{~cm}$-es rétegben $(240-260 \mathrm{~cm})$ jelenik meg kis arányban (1-6\%). Mindez a hordalék felhalmozódásának igen lassú ütemére utal. A következő üledékrétegben (120-200 $\mathrm{cm})$ a homokfrakció aránya némileg megnő (9-21\%), amely az elöntések nagyobb energiaviszonyaira utalhat, amely lehetővé tette nagyobb mennyiségü homok felhalmozódását a folyóhát felszínén. Ezen réteg felett $(100-120 \mathrm{~cm}$ között) homok ismét nem található a mintákban. A legfelső üledékzónában $(0-100 \mathrm{~cm})$ a homok aránya megnövekedett, és vannak olyan minták (pl. 20-30 cm), ahol kiugróan magas arányban ( $\geq 40 \%)$ képviselteti magát a homokfrakció, aminek a lerakódása egyértelmüen nagy munkavégző képességü árvizek munkáját jelzi.

Az idősebb 20/2-es folyóhát esetében jóval nagyobb mélységig, egészen 380 cm-ig kellett lefúrni ahhoz, hogy megtaláljuk a szabályozási munkálatok előtt kialakult paleo-talaj réteget, ugyanis ez a folyóhát közel 40 évvel hosszabb ideje fejlődik, mint az előbb bemutatott 10/2-es forma. A 20/2-es folyóhát terepen mért magassága megegyezik a DDM alapján meghatározott magassággal $(375 \mathrm{~cm})$. A szabályozási munkálatok előtti paleo-talaj rétegben (370-380 cm) az iszap és az agyag frakciók nagy arányban (64\% és 36\%) képviseltetik magukat. A homokfrakció aránya kismértékben megnő a folyóhát legalsó üledékzónájában $(370-280 \mathrm{~cm})$, de aránya legfeljebb 18\%, azaz ekkor a folyóhátat viszonylag kis munkavégző képességü és nem túl mély vízborítást eredményező árvizek formálhatták. Az e feletti rétegben $(280-240 \mathrm{~cm})$ a homok aránya ismét lecsökken (1-2\%-ra), amely alacsonyabb árvizekkel és lelassult, főleg lebegtetett hordalék-felhalmozódással jellemezhető időszakra utalhat. A folyóhát felsőbb zónáját reprezentáló rétegekben $(0-240 \mathrm{~cm})$ fokozatosan elkezd megnőni a minták a homoktartalma (a 140-180 cm közötti réteg kivételével), és a legfelső 80 cm-ben már a homokfrakció válik a dominánssá, ahol aránya meghaladja a 70\%-ot, ami arra utal, hogy egyre nőtt a folyóhátat betakaró és formáló árvizek energiája és munkavégzőképessége.

Mindkét folyóhát esetében tehát megfigyelhető, hogy fejlődésük elején elsősorban iszap és agyagszemcsék halmozódtak fel, míg a homok aránya kicsi volt. Ez arra utal, hogy épülésük üteme kezdetben jóval lassabb lehetett, amelyből kisebb munkavégző-képességü árvízi elöntésekre következtetek. A felszín felé egyre növekvő homoktartalom azonban a formákat felépítő árvizek hidrológiájában bekövetkező változásokat mutatja. A homokfrakció nagy aránya a mintákban jelzi az egyre növekvő energiájú árvizeket, hiszen a folyó megnövekedett munkavégző-képessége lehetővé teszi, hogy nagyobb mennyiségü homok jusson ki a hullámtérre. Ez kapcsolatba hozható az egyre magasabb árvizekkel (ld. Kiss et al. 2019a), a meder egyre szükebbé válásával (Kiss et al. 2019b), ami fokozza a partél szintje fölé magasodó árvizek munkavégző képességét, és a part menti növényzet egyre sürübbé válásával is. Eredményeim szerint a hullámtér növényzeti érdessége az ötszörösére növekedett a 18. század vége óta, amelyben jelentős szerepe van az invazívan terjedő gyalogakácnak, amely számos ponton sürü, áthatolhatatlan bozótost képez. A durvább szemcse-összetételü, ugráltatva szállítódó homokos hordalék, ebben a sürü növényzettel borított part menti sávban kényszerül felhalmozódni, ugyanis az áthatolhatatlan növénytakaró meggátolja, hogy az árvizekkor szállított homok a hullámtér távolabbi részei felé eljusson, bár nagy valószínűséggel a lebegtetett hordalék tovább szállítódhat, de erre vonatkozó méréseket árvizek hiányában - nem tudtam végezni. 
$0 \quad 102030405060708090100$

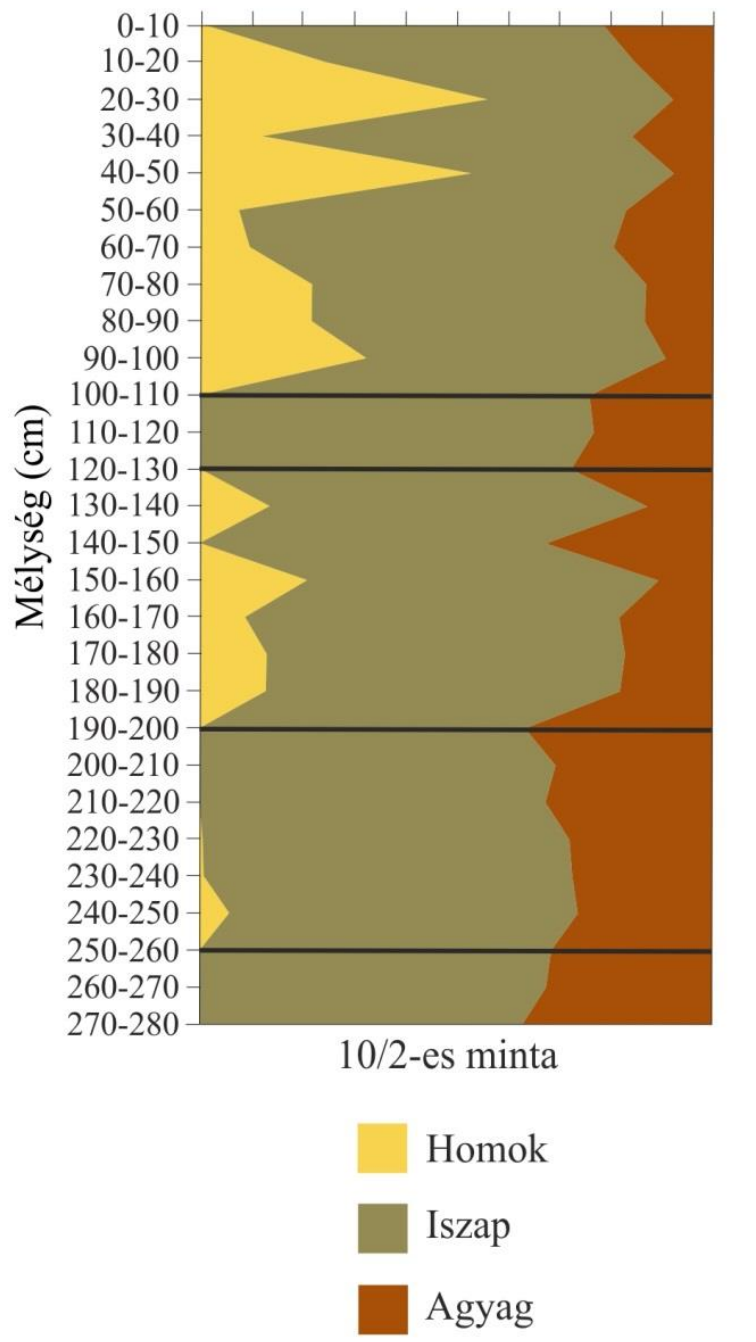

b

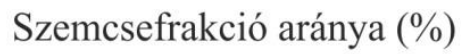

$\begin{array}{llllllllll}0 & 10 & 20 & 30 & 40 & 50 & 60 & 70 & 80 & 90100\end{array}$

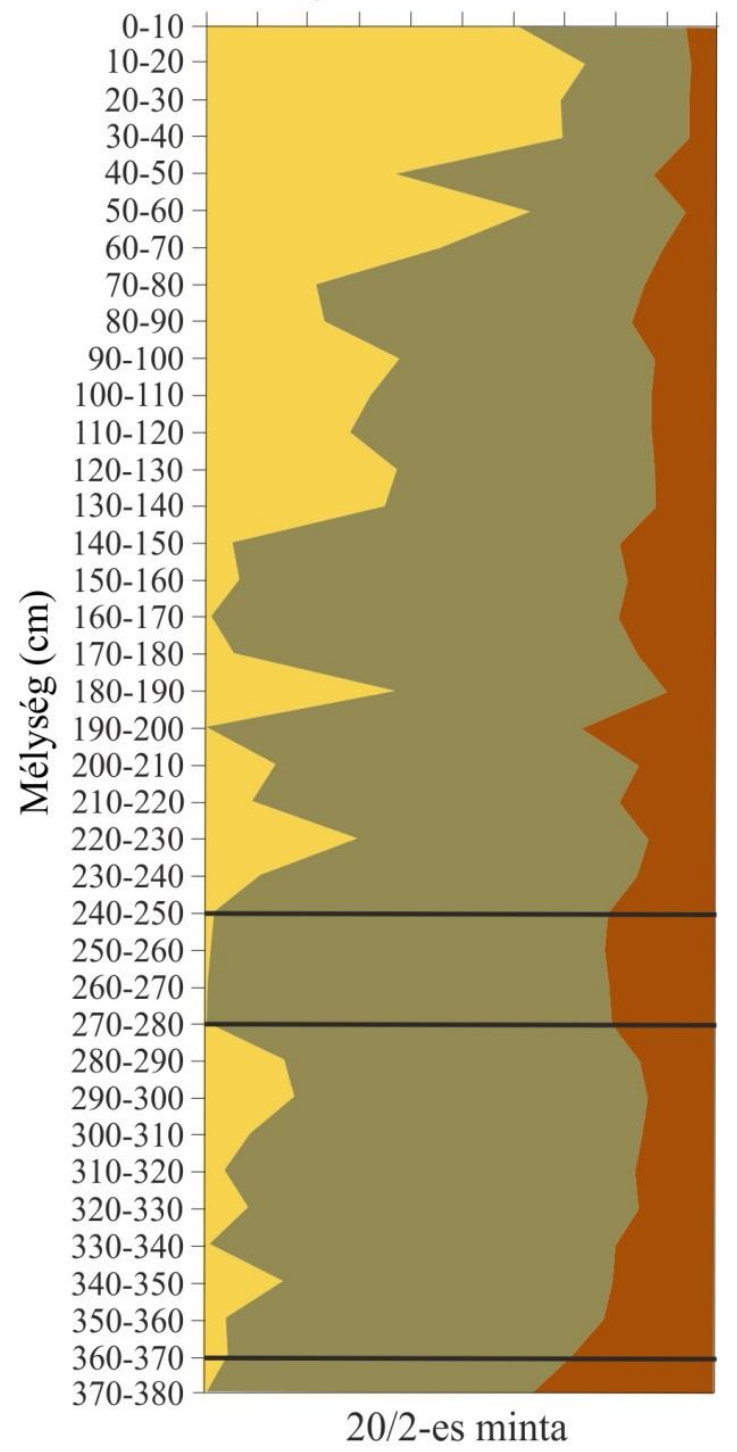

45. ábra. A folyóhátak szemcseösszetételének idöbeli változása egy fiatalabb (a) és egy idösebb (b) folyóhát példáján

\subsection{Horizontális feltöltődés kiemelt helye a kanyarulatok belső ívén: az övzátonyok fejlödése}

Jelen fejezetben a hullámtér horizontális feltöltődésének kiemelt formáinak, az övzátonyok vizsgálatával foglalkozom. Az eredményeimet három mintakanyarulat fejlődésének részletes bemutatásával kezdem, amely arra világít rá, hogy a térben egymáshoz közel elhelyezkedő és hasonló ideje fejlődő kanyarulatok mentén igen változatos számú és morfológiájú övzátonyok fejlődtek. Ezt követően eredményeimet az Alsó-Tisza mentén a partelmozdulás ütemének hosszú távú változásának, a különböző kanyarulatvándorlási típusok, illetve az övzátony-sorok fejlődési típusainak bemutatásával folytatom. Megvizsgáltam azt is, hogy az egyes kanyarulatokon belül az övzátony-sorokat alkotó tagok magasságát és szélességét milyen tényezők befolyásolják. Ezen tényezők hatásának azonosítása kiemelten lényeges, hiszen az övzátonyok morfológiájának (elsősorban magasságának) megváltozása hatással lehet a hullámtér vízvezető-képességére. Az övzátonyok fejlődésének módosulása továbbá hatással lehet a meder túloldalán fejlődő folyóhátak formálódására is, így eredményeimet ezen kapcsolat elemzésével zárom. 


\subsubsection{Az övzátony-sorok formálódásának alapvető jellemzői}

Az övzátonyok fejlődését és morfológiai tulajdonságait befolyásoló tényezők összetett hatását először 3 kanyarulat (15., 20., és 22. számú kanyarulatok) részletes elemzésén keresztül kívánom bemutatni. A választásom azért ezekre a kanyarulatokra esett, mert (1) különböző kanyarulatfejlődési típusba tartoznak (megnyúló, elforduló és áthelyeződő); (2) mindegyik hosszabb ideje fejlődik, azaz már az 1780-as éveket megelőzően is léteztek; továbbá (3) térben közel helyezkednek el egymáshoz, ennek ellenére fejlődésük eltérö ütemben zajlott, és a kialakult övzátonyok morfológiája is igen változatos; (4) a vizsgált kanyarulatok eltérő kötöttségü üledékekben fejlődnek; végül (5) eltérő mértékü az antropogén befolyásoltságuk is. A 15 . sz. kanyarulat például laza anyagban és gyors ütemben vándorol és partbiztosításokkal erösen szabályozott, míg a 20. számú kanyarulat kötött üledékekben fejlődik és a külső ív szintén partbiztosított, illetve a 22. számú kanyarulat nincs partbiztosítva, szabadon vándorol, és kötött anyagban fejlödik.

\section{A) Az elforduló csanyteleki kanyarulat és övzátonyainak fejlödése}

A 15. sz. kanyarulat (225-227 fkm) Csanytelektől keletre található (4. ábra). A kanyarulat jelenlegi görbületi sugara $520 \mathrm{~m}$, a hullámtér átlagos szélessége pedig $2700 \mathrm{~m}$. E kanyarulat mentén alakult ki a legtöbb tagú (19) övzátony-sor az összes alsó-tiszai kanyarulat közül (46. ábra és 9. táblázat). A kanyarulat a rendelkezésre álló térképek alapján már az 1780-as évek elött is létezett, de az intenzív partelmozdulás és az elforduló kanyarulatvándorlás miatt a kanyarulat északabbra helyezkedett el, így az akkor kialakult övzátonyokat azóta vagy elmosta a Tisza, vagy hordalékkal betemetödtek, így ezek a formák a jelenlegi hullámtéren már nem is látszódnak. Ebből adódóan a kanyarulat ma is látható övzátonyai csak az 1890. évi felmérés után keletkeztek.

A partelmozdulás sebessége az 1783. és az 1861. évi felmérések között az akkori kanyarulat csúcspontján, a belső íven $1,1 \mathrm{~m} / \mathrm{e} v$, a külső íven pedig $0,7 \mathrm{~m} / \mathrm{év}$ lehetett. A partelmozdulás tehát a belső íven gyorsabb volt, amelynek eredményeként a meder szélessége 230 m-röl 170 m-re csökkent. Ezek az értékek azonban rejtenek némi bizonytalanságot magukban, mert az 1783-as felmérésen a meder futásvonalát némely szakaszokon pontatlanul rajzolhatták meg. Ez föleg azokon a helyeken jellemző, ahol nagy kiterjedésű mocsár szegélyezte a folyót, így a meder megközelítése nehézkes volt.

Az 1890. évi felmérésig eltelt közel 30 évben a partelmozdulás iránya némileg változott. A meder fejlődése nem keleti irányban folytatódott, hanem kissé nyugatabbra vándorolt. A kanyarulat belső ívén ekkor $-1,1 \mathrm{~m} /$ év volt a partelmozdulás sebessége, tehát inkább erózió jellemezte, míg a külső íven -0,4 m/év volt, így ezen az oldalon inkább az akkumulációs folyamatok domináltak. A meder szélesebbé vált $(195 \mathrm{~m})$, amely a mintaterülettől közvetlenül felvízi irányban, a 1863 és 1886 között végzett két kanyarulat átvágásnak (Sulymostó I. és II.; Pálfai 2001) tulajdonítható, hiszen a megnövekedett esés okozta intenzívebb munkavégzöképesség a meder kiszélesedését eredményezte. Az ebben az időszakban formálódott övzátonyok azonban nem azonosíthatók a jelenkori hullámtéren a parterózió miatt.

A kanyarulat-átvágások még az 1890 és 1929 közötti időszakban is éreztették hatásukat, mivel a meder elmozdulása intenzívebbé vált. Ekkor a kanyarulat belső ívén a partelmozdulás mértéke $1,5 \mathrm{~m} / \mathrm{e} v$, a külső íven pedig $0,8 \mathrm{~m} /$ év volt. Mivel a belső ív gyorsabban fejlődött, a meder ismét szükült, szélessége 1929-ben 185 m volt. A gyors partelmozdulás eredményeképpen intenzív övzátony-épülés zajlott, és ekkor kezdtek el formálódni azok az övzátonyok, amelyek ma a felszínen is látszódnak. Ebben az időszakban 10 övzátony (Ö1-10) képződött, amelyek magassága átlagosan $1,9 \mathrm{~m}$, átlagszélességük $26 \mathrm{~m}$, a közöttük lévő távolság pedig átlagosan 30 m. Az övzátonyok kis szélessége és közel azonos magassága jól tükrözi a gyors partelmozdulást. Az ekkor képződött folyóhát egy része megmaradhatott a mai hullámtéren a jelenlegi folyóhát felvízi szakaszán, azonban ezt a későbbiekben befedte a később lerakódó ártéri hordalék és az új folyóhát anyaga. 
A kanyarulatvándorlás továbbra is intenzív maradt 1929 és 1976 között, átlagos üteme a belső íven 1,3 m/év, a külső íven pedig 1,4 m/év volt, a meder átlagos szélessége ekkor $175 \mathrm{~m}$ volt. A gyors partelmozdulást elősegíthette az, hogy a kanyarulat külső ívén az erózió nem kötött anyagban zajlott, hanem a folyásirányban lefelé elhelyezkedő 16. sz. kanyarulat egykori övzátony-sorának viszonylag laza üledékében. Ebben az időszakban összesen 8 övzátony épült (Ö11-18). Ezek már alacsonyabbak, átlagosan 17,3 m magasak (1,1-2,6 m), és keskenyebbek, átlagosan $22 \mathrm{~m}$ szélesek (12-37 m), illetve a közöttük lévő távolság is csökkent átlagosan 29 m-re. Az övzátony-sorról készített keresztmetszeten jól látszódik, hogy az Ö11-ig hasonlóan alakult az övzátonyok magassága (átlagosan 1,9 m). Azonban az Ö13 tagtól kezdődően megváltozott az övzátonyok fejlödése, magasságuk hirtelen lecsökkent (2,3 m-röl 1,7 m-re) és azután is fokozatosan csökkent egészen az Ö17-ig, amely a meder bevágódására utalhat. A kanyarulatot továbbra is az elforduló fejlődés jellemezte, de az Ö13 tagtól kezdve ennek iránya kissé módosult. Ezen kívül megfigyelhető, hogy az ebben az időszakban épült övzátonyok közül az utolsó tag (Ö18) csaknem kétszer olyan magas $(2,6 \mathrm{~m})$, mint az azt megelőző övzátony magassága. Ezt eredményezhette az 1966-ban a kanyarulat külső oldalán megépített partbiztosítás, amelynek hatására a következő időszakban jelentősen lecsökkent a partelmozdulás üteme.

Az 1976. évi felmérést követően (2014-ig) a partelmozdulás sebessége a töredékére csökkent, a belső oldalon $0,1 \mathrm{~m} /$ évre, a külső oldalon a partbiztosítás hatására pedig gyakorlatilag megszünt a partelmozdulás. Ennek eredményeként a meder tovább szükült, és 2014-ben már csak 160 m széles volt. Ebben az időszakban mindössze egy övzátony képződött, amelynek szélessége csupán $11 \mathrm{~m}$, magassága azonban $3 \mathrm{~m}$. A kanyarulat külső ívén a kanyarulat kis görbületi sugara és a széles hullámtér lehetővé tette egy nagyméretü folyóhát kialakulását, amely jelenleg $4,7 \mathrm{~m}$ magas és 460 m széles.

A két utolsó övzátony magassága (2,6 és $3 \mathrm{~m})$ jól mutatja a partelmozdulás lassuló jellegét. A belső ív elmozdulásának lassuló üteme, illetve a külső íven a laterális erózió megállása az 1966-ban megépített partbiztosítás egyértelmü következménye, továbbá jelentős lehet a part menti egyre sürübbé váló növényzet hatása is. A sürübb hullámtéri növényzet miatt ugyanis árvízkor a mederben egyre nagyobb a vízsebesség (Kiss et al. 2019), míg a hullámtéren erőteljesen lecsökken. Mivel a sürü növényzet megakadályozza, hogy a hordalék a hullámtér távolabbi területei felé is eljusson, ezért annak nagy része a part mentén felhalmozódik. Mindezek eredményeképpen a hordalék oldalirányú felhalmozódása megállt, és a folyamatot felváltotta a vertikális akkumuláció, amely a legfiatalabb övzátonyok magasságának növekedését eredményezi.

9. táblázat. A csanyteleki (15. sz.) kanyarulat mentén épülö övzátonyok és folyóhátak jellemzöi, illetve a kanyarulatvándorlás mértéke a 18. század végétöl

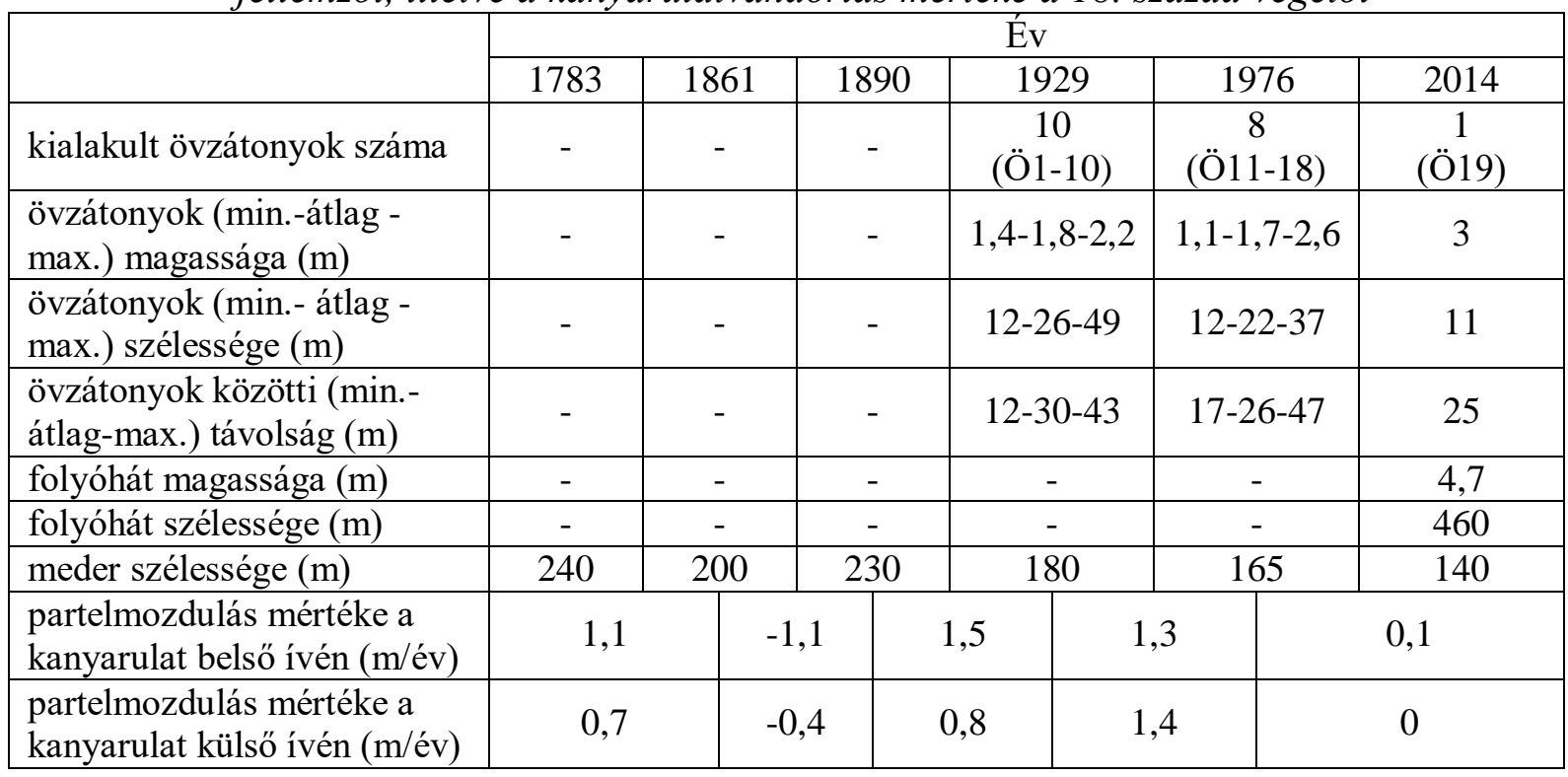



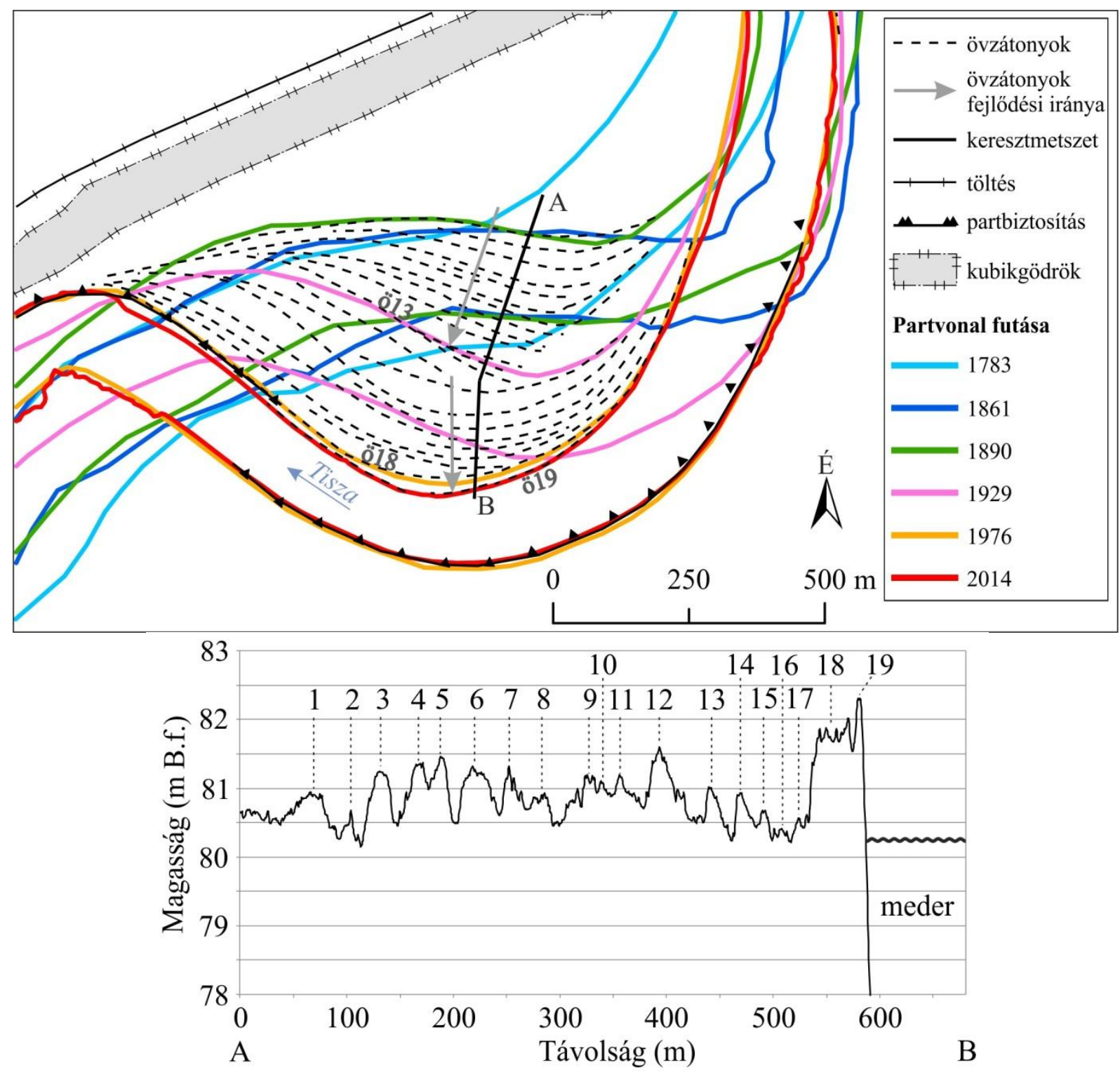

46. ábra. Kanyarulatvándorlás a 15. sz. kanyarulat mentén az 18. század vége óta, valamint az övzátony-soron át készült keresztmetszet

\section{B) A megnyúló mindszenti kanyarulat és övzátonyainak fejlődése}

A 20. sz. kanyarulat Mindszenttől nyugatra helyezkedik el (214,2-217,2 fkm), a mártélyi öblözettől északra (4. ábra). A kanyarulat jelenlegi görbületi sugara $915 \mathrm{~m}$, a hullámtér pedig viszonylag szük $(800 \mathrm{~m})$. Az összes Alsó-Tisza mentén található kanyarulat közül itt a legkisebb a kanyarulatvándorlás átlagos üteme, a 18. század vége óta a belső íven átlagosan $0,3 \mathrm{~m} / \mathrm{e} v$, a külső íven pedig $0,1 \mathrm{~m} / \mathrm{év}$ ütemmel vándorolt a meder. A hosszú fejlödés ellenére a mai aktív hullámtéren mindössze 5 övzátony-formát lehet elkülöníteni. A kanyarulatvándorlás típusát tekintve a megnyúló típusba sorolható.

Hasonlóan a csanyteleki kanyarulathoz, ez a kanyarulat is létezett már az 1783. évi térképezést megelőzően is (47. ábra). A felmérés idején a meder széles volt $(225 \mathrm{~m})$, és helyzete alapján arra lehet következtetni, hogy az övzátony-sor két legidösebb tagja (Ö1-2) már létezett, amelyek viszonylag alacsonyak $(1,1 \mathrm{~m}$ és $2,3 \mathrm{~m})$ de szélesek voltak ( $82 \mathrm{~m}$ és 76 $\mathrm{m})$ és egymástól távol $(140 \mathrm{~m})$ helyezkedtek el (10. táblázat). Az övzátonyok morfológiai tulajdonságai azt jelzik, hogy a kanyarulatvándorlás már a korábbi időszakokban is lassú volt, amely széles és egymástól távol elhelyezkedő övzátonyok kialakulását eredményezte. 
10. táblázat. A 20. sz. (mindszenti) kanyarulat mentén épülö övzátonyok és folyóhátak jellemzöi, illetve a kanyarulatvándorlás mértéke a 18. század végétöl

\begin{tabular}{|c|c|c|c|c|c|c|}
\hline & \multicolumn{6}{|c|}{ Év } \\
\hline & 1783 & 1861 & 1890 & 1929 & 1976 & 2014 \\
\hline kialakult övzátonyok száma & $\begin{array}{c}2 \\
(\mathrm{O} 1-2)\end{array}$ & - & - & $\begin{array}{c}2 \\
(\mathrm{O} 3-4)\end{array}$ & $\begin{array}{c}1 \\
\text { (Ö5) }\end{array}$ & - \\
\hline $\begin{array}{l}\text { övzátonyok (min.-átlag - } \\
\text { max.) magassága }(\mathrm{m})\end{array}$ & $\begin{array}{c}1,1-1,7- \\
2,3\end{array}$ & - & - & $\begin{array}{l}3,3-3,0- \\
2,8\end{array}$ & 3,1 & - \\
\hline $\begin{array}{l}\text { övzátonyok (min.- átlag - } \\
\text { max.) szélessége (m) }\end{array}$ & $82-79-76$ & - & - & $55-35-14$ & 17 & - \\
\hline $\begin{array}{l}\text { övzátonyok közötti (min.- } \\
\text { átlag-max.) távolság (m) }\end{array}$ & 140 & - & - & 22 & 23 & - \\
\hline folyóhát magassága (m) & - & - & - & - & - & 3,8 \\
\hline folyóhát szélessége (m) & - & - & - & - & - & 30 \\
\hline meder szélessége (m) & 205 & 155 & 240 & 170 & 150 & 150 \\
\hline $\begin{array}{l}\text { partelmozdulás mértéke a } \\
\text { kanyarulat belső ívén (m/év) }\end{array}$ & 0,6 & & & 0,9 & & 0 \\
\hline $\begin{array}{l}\text { partelmozdulás mértéke a } \\
\text { kanyarulat külső ívén (m/év) }\end{array}$ & $-1,2$ & & & $-0,3$ & & 0 \\
\hline
\end{tabular}

Az 1783 és 1861 közötti időszakban a partelmozdulás átlagos üteme a belső íven 0,6 m/év, a külső íven pedig -1,2 m/év volt, tehát a kanyarulat külső ívét inkább az akkumulációs folyamatok jellemezték, ami mederszükülést eredményezett (1861: 155m). Ebben az időszakban csupán egy övzátony indulhatott fejlödésnek, azonban ez a következő időszakban jellemző erózió miatt elpusztult, így ennek magassági és szélességi viszonyai nem ismertek.

A meder közel 100 méterrel lett szélesebb 1861 és 1890 között $(240 \mathrm{~m})$, hiszen ebben az időszakban a kanyarulat külső ívének elmozdulása gyorsabb ütemben zajlott ( $2 \mathrm{~m} / \mathrm{év})$, míg a belső ív elmozdulása átlagosan $-0,7 \mathrm{~m} / \mathrm{é}^{\mathrm{v}}$ volt, így a meder ezen oldala is inkább erodálódott. A hordalék akkumulációja csupán egy $170 \mathrm{~m}$ hosszú szakaszon figyelhető meg, ahol a partelmozdulás üteme $0,4 \mathrm{~m} /$ év volt. A belső íven jellemző erózió miatt ebben az időszakban új övzátony nem képződött. A meder kiszélesedésének oka az 1862-1887 és 1882-1892 között, a mintaterülettől alvízi irányban zajló mártélyi és körtvélyesi kanyarulatok átmetszése lehetett, amely következtében megnőtt a folyó munkavégző képessége ami felvízi irányban is hatott, hiszen itt is nőtt az esés.

A kanyarulat fejlödése megváltozott 1890 és 1929 között, ugyanis 1910-ben partbiztosítást építettek a külső íven. Ennek eredményeképpen a külső ív mentén inkább akkumuláció lépett fel (partelmozdulás: $-0,3 \mathrm{~m} / \mathrm{e} v$ ), míg a belső ív vándorlása $0,9 \mathrm{~m} / \mathrm{e} v$ re gyorsult. Mindez a meder szükülését eredményezte, amely az 1929. évi felmérés idején csupán 170 m-volt. A felgyorsult hordalék-felhalmozódás következtében két övzátony formálódott (Ö3-4) amelyek alaktani tulajdonságai meglehetősen eltérők. Az Ö3 övzátony a legmagasabb (3,3 m) és legszélesebb (110 m) az övzátony-sor összes tagja közül. Ennek oka az lehet, hogy a forma már a korábbi időszakokban is fejlődhetett, csak létezését a partvonal korábbi futása alapján nehéz meghatározni. Az Ö4 övzátony keskeny (14 m), de ehhez képest magas $(2,8 \mathrm{~m})$, illetve a két forma közötti távolság is mindössze $22 \mathrm{~m}$, ami tükrözi az ebben az időszakban jellemző gyors partelmozdulást a belső íven.

Az 1929 és 1976 közötti időszakban a kanyarulatvándorlás mérséklődött. A belső íven a part elmozdulásának üteme $0,7 \mathrm{~m} / \mathrm{é}^{\mathrm{v}}$ volt, a külső íven viszont teljesen megállt, amely a kiépített partbiztosítás következménye. Ennek hatása a belső íven keletkezett új övzátony (Ö5) tulajdonságain is tükröződik. A lelassult partelmozdulás (illetve a sürübb part menti növényzet) miatt az övzátony felszínén intenzívebbé váló vertikális akkumuláció 3,1 m magas forma kialakulását eredményezte, amelynek szélessége viszont mindössze $17 \mathrm{~m}$. Összességében tehát az övzátony-sort alkotó tagok magassága folyamatosan nőtt (1,1 m-ről 3,1 m-re) az egyre 
lassuló partelmozdulás következtében. A kanyarulat külső ívén egy 3,8 m magas, de az árvízvédelmi töltés közelsége miatt mindössze $30 \mathrm{~m}$ széles folyóhát alakult ki, amely már a korábbi időszakokban is létezhetett, viszont a külső ív folyamatos eróziója miatt egy része mindig elpusztult, viszont a megmaradó formarészletre rárakódott az új anyag.

Összehasonlítva az előző, csanyteleki kanyarulattal (15. sz.) elmondható, hogy a meder vándorlása a két helyen meglehetősen eltérő ütemben zajlott, holott közel helyezkednek el egymáshoz. Ezt okozhatja az, hogy a két kanyarulat eltérő kötöttségü üledékekben fejlődik. Míg a 15. sz. kanyarulat átdolgozott, laza üledékben fejlödik, addig a 20. sz. kanyarulat esetében a meder anyaga kötöttebb (iszap, agyag). Ráadásul a csanyteleki kanyarulat közelebb $(1 \mathrm{~km})$ van a tőle felvízi irányban végzett átvágásokhoz, míg a mindszentinél ez $4 \mathrm{~km}$, és az átvágás az alvízi szakaszon található. Ezen kívül a két kanyarulat eltérő ideje van partbiztosítva, hiszen a csanyteleki kanyarulat mentén 1966-ban építették meg a partbiztosítás, addig ez a mindszenti kanyarulat külső ívén már 1910-ben megtörtént, ami a kanyarulatvándorlás eltérő sebességét eredményezte a 20 . században a két kanyarulat mentén.
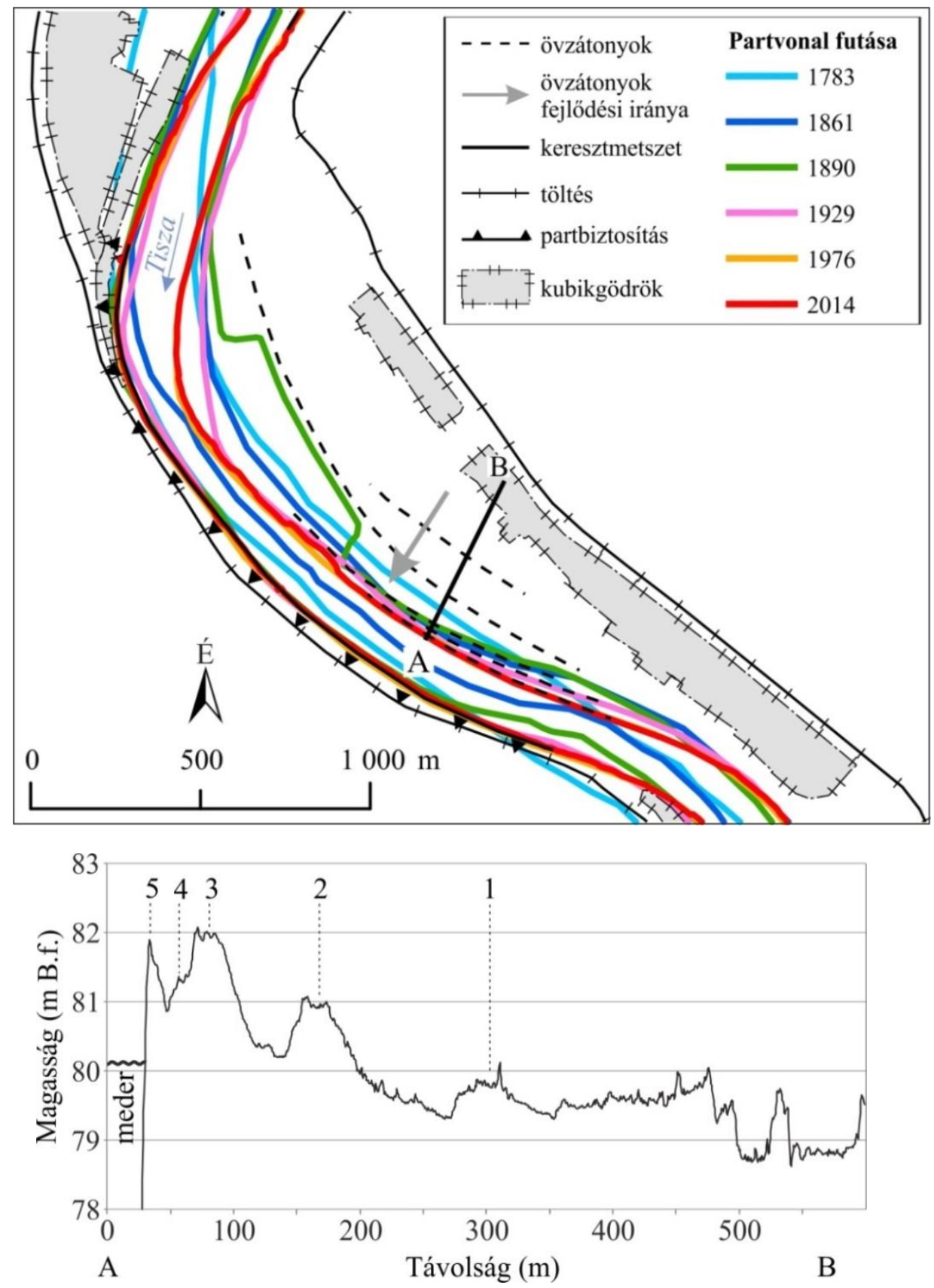

47. ábra. Kanyarulatvándorlás a 20. sz. kanyarulat mentén az 18. század vége óta, valamint az övzátony-soron át készült keresztmetszet 


\section{C) Az áthelyezödö ányási kanyarulat és övzátonyainak fejlödése}

Az ányási, 22. sz. kanyarulat Mindszenttől délre helyezkedik el (211,3-212,2 fkm), közvetlenül a Mártélyi-holtág és -öblözet felett (4. ábra). A kanyarulat görbületi sugara kicsi $(250 \mathrm{~m})$, a hullámtér ezen a szakaszon 1540 m-re szélesedik, ugyanis a kanyarulattól közvetlenül északra és délre is jóval szűkebb (felvízi szakaszon $720 \mathrm{~m}$, alvízi szakaszon pedig $850 \mathrm{~m}$ ). A kanyarulat fejlődési típusa meglehetősen sajátos, ugyanis az áthelyeződő fejlődési típusba tartozik, tehát a kanyarulat hossza és alakja a fejlődés során nem változott (Daniel 1971). Az Alsó-Tisza mentén ez az egy kanyarulat tartozik ebbe a típusba. Ráadásul az ányási kanyarulat direkt emberi hatásoktól mentes, tehát a külső íven nem lett építve partbiztosítás.

Hasonlóan az előző két kanyarulathoz, ez is létezett már az 1780-as évek előtt (48. ábra), habár a belső íven épült övzátonyok mindegyike az 1929. évi felmérés után képződhetett (11. táblázat), mivel a kanyarulat fejlődési típusából adódóan a korábban létezett övzátonyok a folyamatos dél felé való vándorlás során elpusztultak. A belső oldalon összesen 5 övzátony különíthető el. A kanyarulat mentén általános, hogy a kanyarulat csúcspontjától felvízi irányban a belső íven eróziós, a külső íven pedig akkumulációs folyamatok zajlanak, míg alvízi irányban ennek az ellenkezője zajlik, a belső íven akkumulációs, a külső íven pedig eróziós folyamatok jellemzők. Éppen ezért a partelmozdulás sebességét elsősorban az alvízi szakaszon jellemzem, hiszen a belső íven az övzátonyok itt épülnek.

\section{1. táblázat. A 22. sz. (Ányási) kanyarulat mentén épülő övzátonyok és folyóhátak jellemzői,} illetve a kanyarulatvándorlás mértéke a 18. század végétöl

\begin{tabular}{|c|c|c|c|c|c|c|c|}
\hline & \multicolumn{7}{|c|}{ Év } \\
\hline & 1783 & 1861 & & 1890 & 1929 & 1976 & 2014 \\
\hline kialakult övzátonyok száma & - & - & & - & - & $\begin{array}{c}3 \\
(\mathrm{O} 1-3)\end{array}$ & $\begin{array}{c}2 \\
(\ddot{O} 4-5)\end{array}$ \\
\hline $\begin{array}{l}\text { övzátonyok (min.-átlag - } \\
\text { max.) magassága (m) }\end{array}$ & - & - & & - & - & $\begin{array}{c}0,7-0,9- \\
1,3\end{array}$ & $\begin{array}{c}0,2-0,6- \\
0,9\end{array}$ \\
\hline $\begin{array}{l}\text { övzátonyok (min.- átlag - } \\
\text { max.) szélessége (m) }\end{array}$ & - & - & & - & - & $23-30-37$ & $12-20-28$ \\
\hline $\begin{array}{l}\text { övzátonyok közötti (min.- } \\
\text { átlag-max.) távolság (m) }\end{array}$ & - & - & & - & - & $42-39-36$ & 23 \\
\hline folyóhát magassága (m) & - & - & & - & 3,3 & 3,3 & 3,7 \\
\hline folyóhát szélessége (m) & - & - & & - & 105 & 105 & 125 \\
\hline meder szélessége (m) & 205 & 155 & & 165 & 180 & 170 & 175 \\
\hline $\begin{array}{l}\text { partelmozdulás mértéke a } \\
\text { kanyarulat belső ívén (m/év) }\end{array}$ & \multicolumn{2}{|c|}{$-0,2$} & 0,2 & 0,9 & \multicolumn{2}{|l|}{1,2} & 0,3 \\
\hline $\begin{array}{l}\text { partelmozdulás mértéke a } \\
\text { kanyarulat külső ívén (m/év) }\end{array}$ & \multicolumn{2}{|c|}{$-0,3$} & 0,3 & 1,0 & \multicolumn{2}{|l|}{0,7} & 0,2 \\
\hline
\end{tabular}

A kanyarulat az 1783. évi felmérés alapján nagyobb görbületi sugárral rendelkezhetett (kb. $325 \mathrm{~m}$ ), bár ezt pontosan nem lehet meghatározni az I. katonai felmérés pontatlansága miatt. Ezen kívül ekkor a meder is szélesebb lehetett $(205 \mathrm{~m})$. Az 1861. évi felmérés idejére a meder 155 m-re szükült, illetve a kanyarulat görbületi sugara is kisebb lett $(240 \mathrm{~m})$, így a kanyarulat szükebbé vált. A meder futásvonala alapján a partelmozdulás üteme az egész kanyarulat mentén negatív értékeket mutat, hiszen a belső és a külső oldalon is jellemző volt az erózió és az akkumuláció is. A belső íven a partelmozdulás üteme $-0,2 \mathrm{~m} / \mathrm{e} v$ nnek adódott, tehát ezen az íven az erózió dominált, míg a külső íven a partelmozdulás $-0,3 \mathrm{~m} / \mathrm{e} v$ sebességgel zajlott, tehát inkább az akkumulációs folyamatok voltak jellemzőbbek.

Az 1861 és 1890 közötti időszakban a belső íven a hordalék akkumulációja 0,2 m/év ütemmel zajlott, a külső íven pedig 0,3 m/év sebességgel erodálódott a part. Mivel mindkét oldalon a part elmozdulása közel azonos ütemben zajlott, a meder átlagos szélessége csupán enyhén nőtt (165 m). 

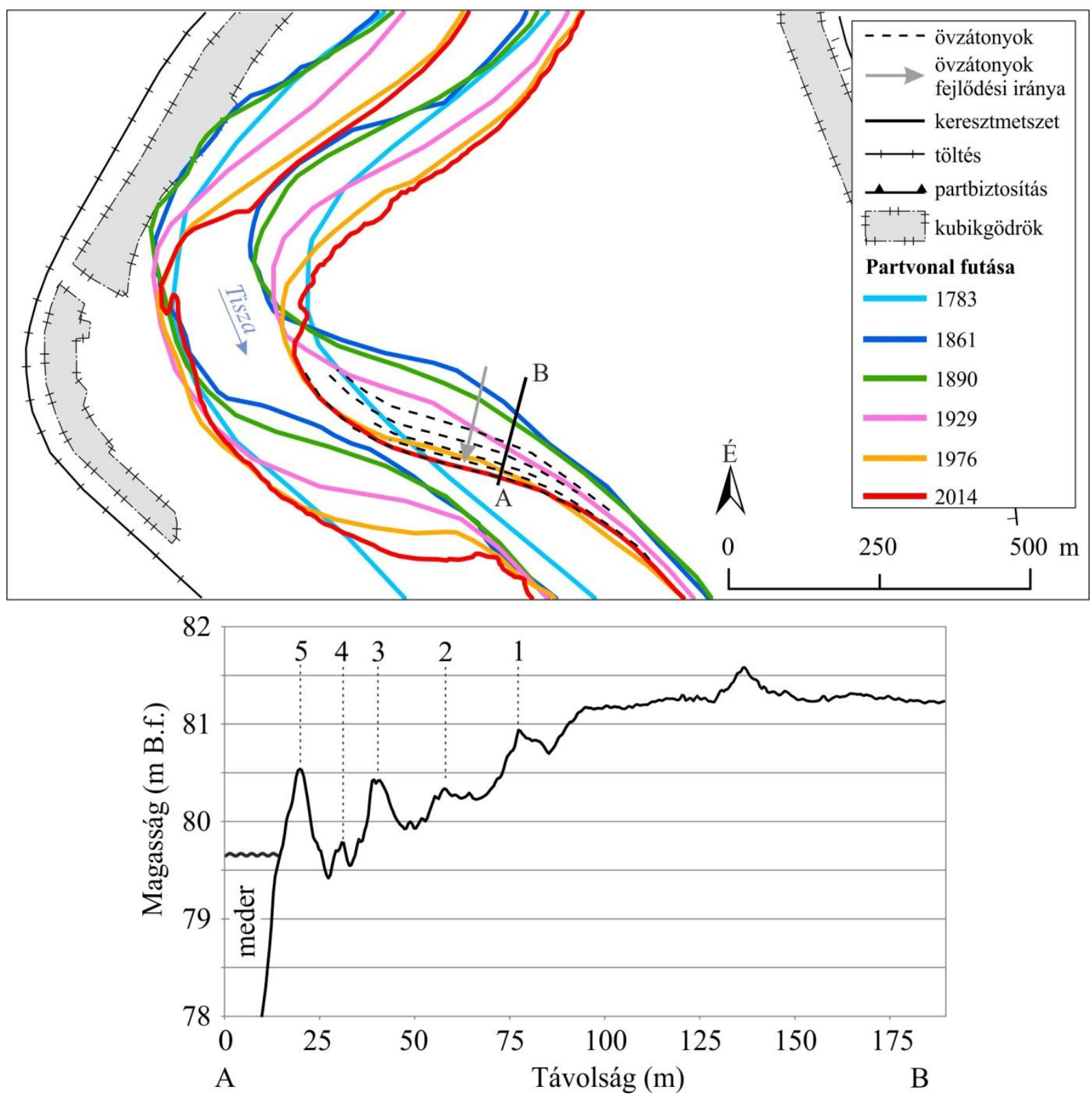

48. ábra. Kanyarulatvándorlás a 22. sz. kanyarulat mentén az 18. század vége óta, valamint az övzátony-soron át készült keresztmetszet

A kanyarulatvándorlás felgyorsult 1890 és 1929 között: a belső íven 0,9 m/évre, a külső íven pedig $1 \mathrm{~m} /$ évre. Ennek oka lehet, hogy a kanyarulattól délre két átvágás is történt: az 1862-1887 közötti zajló átmetszéssel jött létre a Körtvélyesi Holt-Tisza, illetve 1882 és 1892 között zajlott a mártélyi kanyarulat átvágása. Az esésnövekedés következtében felgyorsult munkavégzö-képesség miatt felgyorsult a parterózió, és a meder is némileg kiszélesedett, így 1929-ben szélessége 180 m volt. Az ebben az időszakban keletkezett folyóhát egy része még látható a jelenleg épülő formától felvízi irányban, amely 3,3 m magas és $105 \mathrm{~m}$ széles. A forma azonban ennél szélesebb lehetett, ugyanis a későbbi parterózió egy részét elpusztította.

Az 1929.évi felmérést követően kezdtek el kialakulni azok az övzátonyok, amelyek ma is láthatók a hullámtéren. Az 1976-ig tartó időszakban a partelmozdulás tovább gyorsult, ami leginkább a kanyarulat belső ívén volt jellemző, ahol a partelmozdulás üteme 1,2 m/év volt, a külső íven kicsit lassult, itt a part 0,7 m/év ütemmel erodálódott. A meder szélessége 1976ban átlagosan $170 \mathrm{~m}$ volt. Az övzátonyok közül ebben az időszakban összesen 3 három formálódott (Ö1-3), amelyek átlagos magassága $1 \mathrm{~m}$, szélességük átlagosan $30 \mathrm{~m}$, egymástól való távolságuk pedig $39 \mathrm{~m}$ (11. táblázat). Az övzátonyok magassága folyamatosan csökken a meder irányába (1,3 m-ről 0,8 m-re), amely a mederbevágódását mutathatja. 
Annak ellenére, hogy a kanyarulat külső ívén nem építettek partbiztosítás, lassult a kanyarulatvándorlás az 1976 és 2014 közötti időszakban, hiszen a belső íven 0,3 m/év, a külső íven pedig $0,2 \mathrm{~m} /$ év volt a partelmozdulás átlagos üteme. Mivel a két partvonal elmozdulása közel hasonló ütemben zajlott, ezért a meder szélessége alig változott $(175 \mathrm{~m})$. Ebben az időszakban két további övzátony keletkezett (Ö4-5), amelyek alacsonyabbak (0,2 m és $0,9 \mathrm{~m}$ ) és keskenyebbek ( $12 \mathrm{~m}$ és $28 \mathrm{~m}$ ), mint az idősebb övzátonyok, illetve a közöttük lévő távolság is csökkent. Az övzátony-sor utolsó tagjának magassága $(0,9 \mathrm{~m})$ itt is meghaladja az előző tagok magasságát a partbiztosítás hiányának ellenére, bár ez a magasságkülönbség nem olyan nagymértékü, mint az elöző két bemutatott kanyarulat esetében. A kanyarulat külső ívén jelenleg is épül egy folyóhát, amely magasabb és szélesebb, mint elődei.

\subsubsection{Kanyarulatvándorlási típusok az Alsó-Tisza mentén}

Mint ahogyan azt láttuk az előző három kanyarulat esetében a kanyarulatvándorlás típusa befolyásolja az övzátonyok fejlődési irányát, ezért megvizsgáltam, hogy az AlsóTisza mentén milyen kanyarulatvándorlási típusok vannak. A mintaterületen három különböző kanyarulatvándorlási típus különböztethető meg. A leggyakoribbak a megnyúló kanyarulatok, amelybe a vizsgált 33 kanyarulat közül 23 sorolható, és amelyek görbületi sugara jellemzően 750 m-nél nagyobb. Térbeli elhelyezkedésüket tekintve megállapítható, hogy ezen kanyarulatok többsége a mederrendezés során kiegyenesített szakaszokon található, kivéve néhány természetes kanyarulatot (pl. Mindszentnél a 1920. sz. kanyarulatok), ahol a kötöttebb mederanyag lehet a megnyúló vándorlástípus oka. A mintaterület északi felében (Mindszenttől északra), három kivételével az összes kanyarulat ebbe a típusba tartozik (49. ábra). Az Alsó-Tisza mentén azonban a mederanyag kötöttsége igen változó (Hernesz 2015), így a megnyúló kanyarulatok fejlődésük előrehaladtával a későbbiekben valószínűleg elfordulóvá válhatnak. Az elforduló kanyarulattípus kialakulásának egyik oka ugyanis a mederanyag kötöttségének változatossága, így ahol a meder lazább, ott a külső ív gyorsabb ütemben pusztul (Daniel 1971).

Az elforduló kanyarulatok típusába összesen 9 kanyarulat tartozik, mindegyikük 750 m-nél kisebb görbületi sugárral rendelkezik. E típusú kanyarulatok leginkább a mintaterület déli részén (Mindszenttől délre) helyezkednek el, illetve azokon a szakaszokon, amelyek a folyószabályozások során érintetlenek maradtak.

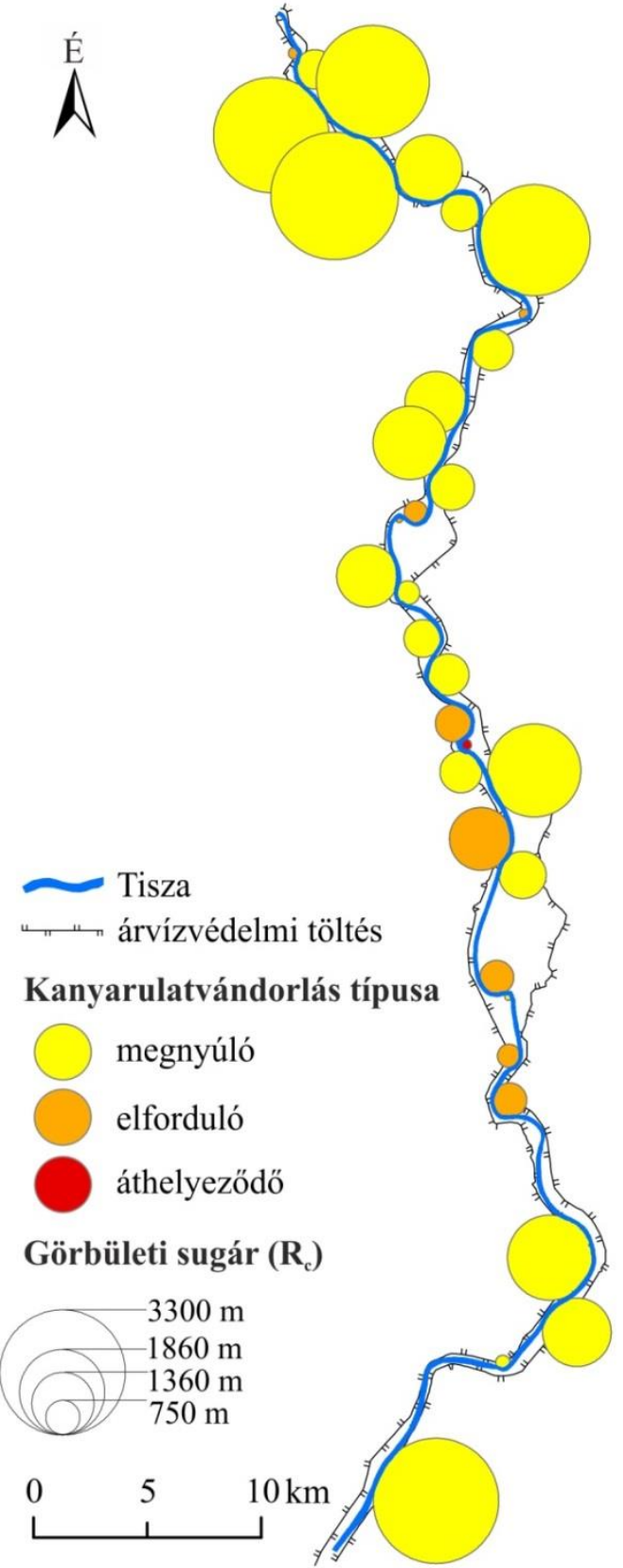

49. ábra. Az Alsó-Tisza mentén elöforduló kanyarulatok vándorlási típusai és görbületi sugaruk 
Közvetlenül a kanyarulatok felett azonban történtek átvágások, ami magyarázhatja a kanyarulatok elforduló jellegét: eredetileg is kis görbületi sugárral rendelkeztek, így a fentebb elhelyezkedő egyenes szakaszokon felgyorsult víz nagy sebességgel nekiütközött a külső ívnek a kanyarulat alsó harmadában, így az gyorsabban pusztult.

Athelyeződö kanyarulat csupán egy fordul elő az Alsó-Tisza mentén, ami egy napjainkig szabadon fejlődő kanyar Mindszenttől délre (Ányási-kanyarulat). Kialakulása lokális okokra vezethető vissza, hiszen itt a kanyarulat egy paleomeder laza anyagú aljzatába van bezárva (Hernesz 2015).

\subsubsection{A partelmozdulás üteme az Alsó-Tiszán}

A három esettanulmányként bemutatott kanyarulat övzátony-sorai azt mutatják, hogy a partelmozdulás üteme és trendje alapvetően befolyásolja vertikális és horizontális kiterjedésüket. Ezért megvizsgáltam az Alsó-Tisza mentén a partelmozdulás ütemének hosszú távú (18. század vége óta tartó) változását. Megállapítható, hogy a mintaterületen általánosan jellemző a partelmozdulás ütemének folyamatos lassulása. Mivel az 1783. évi I. katonai felmérés idején a vizsgált kanyarulatok közül csupán 10 létezett, majd a II. katonai felmérés (1864) lapjain már 15 kanyarulat szerepel a mai kanyarulatok közül, ezért csak a kezdetektől létező kanyarulatok fejlödési ütemét tudtam összehasonlítani az időszak elején (50. ábra). Az I. és a II. katonai felmérés között a kanyarulatok külső ívének átlagos elmozdulása 1,4 m/év (1,7-12 m/év), a belső ívé pedig átlagosan 1,7 m/év (-1,7-11,5 m/év) volt. Mivel a belső ív gyorsabban vándorolt, ezért mederszükülés volt jellemző az I. és II. katonai felmérés között: 1783-ban a meder viszonylag széles volt (átlagosan: $197 \mathrm{~m}$ ), majd 1864-ig 175 m-re szükült. $\mathrm{Az}$ I. katonai felmérés lapjai azonban elég sok pontatlanságot és elnagyolt ábrázolást tartalmazhatnak, főleg azokon a szakaszokon, amelyek nehezen megközelíthetők voltak.

Az 1890. évi felmérésig eltelt időszakban a meder szélesedése tapasztalható (átlagosan 192 m-re). A kanyarulatok külső ívén ugyanis az átlagos erózió (0,7 m/év; min: -0,4, max: 2,2 m/év) bár mérséklődött, a kanyarulatok belső ívén viszont ugyancsak megjelent a part eróziója, ugyanis a belső ív elmozdulásának üteme átlagosan -0,3 m/évnek (-2,5-1,5 m/év) adódott. Véleményem szerint ennek hátterében a kanyarulatok átvágása állhat, amelynek hatására a meder kiszélesedett, részben az övzátonyok rovására. Ez különösen kifejezett az átvágások alatti szakaszokon, ahol a megnőtt esés következtében a folyó megnövekedett energiája a meder erőteljesebb kiszélesedését eredményezte.

$\mathrm{Az}$ 1929. évi felmérésig a meder szélessége ismét lecsökkent (átlagosan 178 m-re), hiszen a belső ív fejlődése ismét intenzívebbé vált. A belső ív elmozdulásának üteme átlagosan 1,1 m/évre (-0,3-3,5 m/év) gyorsult, míg a külső ív elmozdulásának átlagos sebessége $0,5 \mathrm{~m} /$ évre (-0,9-2,4 m/év) mérséklődött.

A következő időszakban (1929-1976) a mederfejlődése hasonló jelleggel zajlott, hiszen a meder tovább szükült (159 m), mivel a külső ív elmozdulása 0,3 m/évre (-0,6-1,5 m/év) csökkent, míg a kanyarulatok belső ívén a part elmozdulása intenzív maradt, átlagosan 0,7 m/év (-0,3-1,8 m/év). Ezek a folyamatok kapcsolatba hozhatók azzal, hogy a legtöbb kanyarulat külsö ívén megépült a partbiztosítás (ekkor már összesen 27 kanyarulat mentén voltak kőrakatok), amely megállította a külső ív vándorlását, miközben a belső íven zajló akkumulációs folyamatok tovább folytatódhattak.

A legutolsó időszakban (1976-2014) a kanyarulatvándorlás gyakorlatilag megszünt vagy erőteljesen lelassult, még azon kanyarulatok esetében is, ahol nincs partbiztosítás. A part elmozdulásának üteme a külső íven átlagosan $0,03 \mathrm{~m} / \mathrm{e} v$, de ez kanyarulatonként $-0,3$ és 0,4 $\mathrm{m} / \mathrm{e} v$ között változik. A belső íven is hasonló az elmozdulás sebessége, átlagosan 0,02 $\mathrm{m} / \mathrm{e} v$, kanyarulatonként pedig -0,2 és $0,3 \mathrm{~m} / \mathrm{e} v$ között van (ami a mérések hibahatára körüli érték). A meder szélessége a leálló folyamatok miatt nem változott, átlagosan mindössze $159 \mathrm{~m}$ volt. 


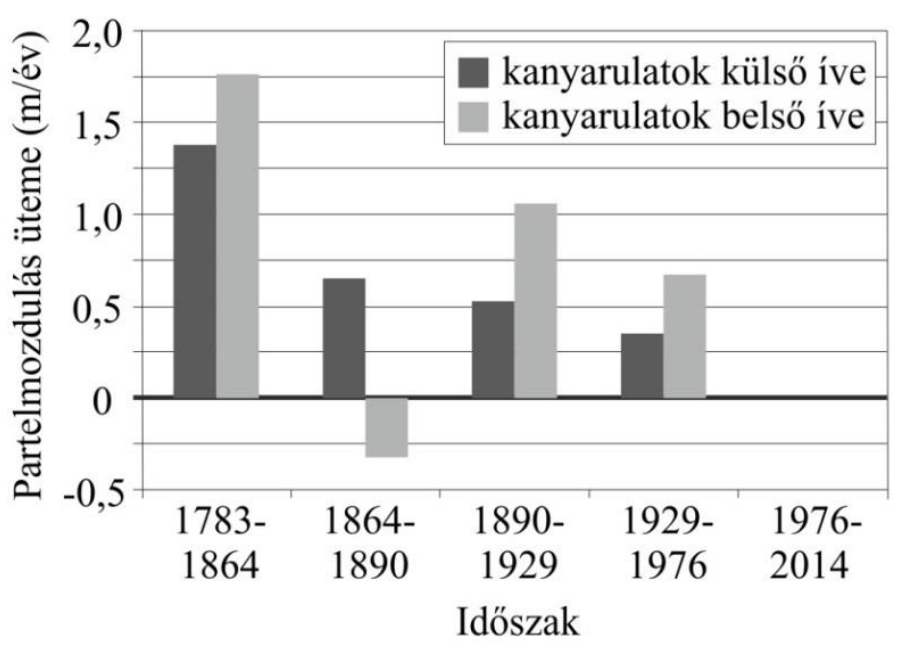

50. ábra. A partelmozdulás átlagos ütemének változása a 18. század vége óta az Alsó-Tisza menti kanyarulatok külsö és belsö ivén

A partelmozdulás hosszú távú változása alapján megállapítható, hogy az Alsó-Tiszán meglehetősen széles skálán mozgott a belső és a külső ív elmozdulásának üteme, hiszen ugyanazon időszakon belül sebessége kanyarulatonként nagyon különböző volt. Ez arra utal, hogy a kanyarulatok vándorlását számos helyi tényező is befolyásolhatja, mint például a kanyarulatok görbületi sugara, a meder szélessége, milyen kötöttségü üledékekben fejlődik az adott kanyarulat, mikor építették a partbiztosítást, van-e a kanyarulat felvízi részén kanyarulat-átvágás, milyen szük a hullámtér, stb. Mindez pedig hatással van az övzátonyépülés sebességére, illetve a kialakuló övzátonyok magasságára és szélességére is.

\subsection{4. Övzátony-sorok típusai az, Alsó-Tiszán}

Az elemzések során nyilvánvalóvá vált, hogy a mintaterületen az egyes kanyarulatokon belül jellegzetes térbeli trend jellemzi az övzátonyok méreteit, ami alapvetően tükrözi a bennük zajló akkumulációs folyamatok jellegzetességeit. Ezért az övzátony-soroknak különböző típusait különítettem el.

\section{A) Az övzátony-sorok típusai magasságuk alapján}

Az Alsó-Tisza 33 vizsgált kanyarulata mentén az övzátony-soroknak 3 típusa különböztethető meg magassági viszonyaik alapján (51. ábra). Itt fontos kiemelnem, hogy a különböző csoportok meghatározását az utolsó, emberi hatásra (partbiztosítások, kanyarulatátvágások) módosuló övzátony-tagok nélkül végeztem el.

Az első típus esetében az övzátony-sort alkotó tagok magassága fokozatosan csökken a meder irányában (51a. ábra). Ebbe a típusba a kanyarulatok 36\%-a (12 db) tartozik. Az övzátony-sort alkotó tagok közötti magasságcsökkenés átlagosan 0,9 m (0,2-1,4 m). Azonban az egyes övzátony-sorok eltérő tagszámmal rendelkeznek, így ha egy övzátony-soron belül a teljes magasságcsökkenés értékét elosztjuk a tagok számával, akkor ez a csökkenés az egyes tagok között 0,2-0,8 m/tagnak adódik. Véleményem szerint az övzátony-tagok magasságának csökkenése utalhat:

- a meder bevágódására, hiszen ezt követve - ha az övzátonyok fejlödési körülményei és az erre rendelkezésre álló idő nem változik - az övzátonyoknak alacsonyodniuk kell;

- a kanyarulatvándorlás sebességének növekedésére, mivel ebben az esetben egyre rövidebb idő áll rendelkezésre a forma felépülésére, így az egyes övzátonyok egyre alacsonyabbak maradnak; 
- az övzátonyt felépítő fenék- és lebegtetett hordalék hozamának csökkenésére is, ugyanis így egyre hosszabb idő kellene a forma felépítéséhez, miközben változatlan parterózió mellett ez nem áll rendelkezésre.

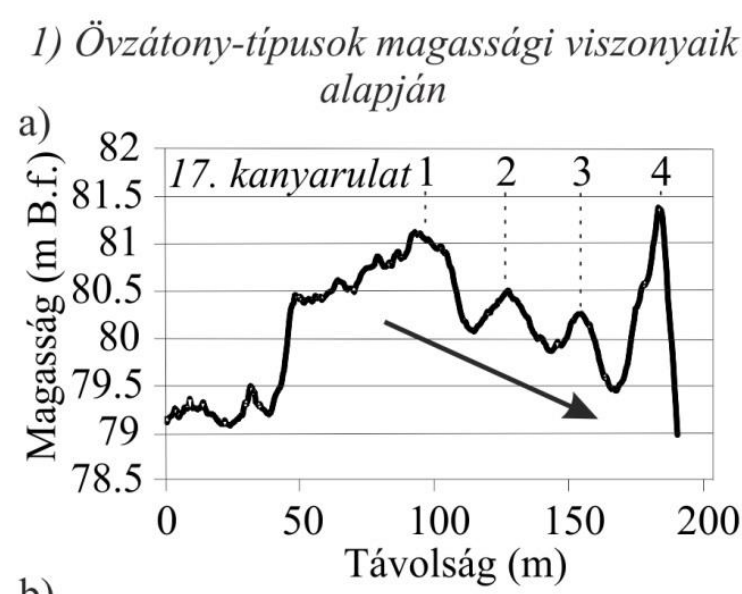

2) Övzátony-tipusok szélességi viszonyaik
alapján
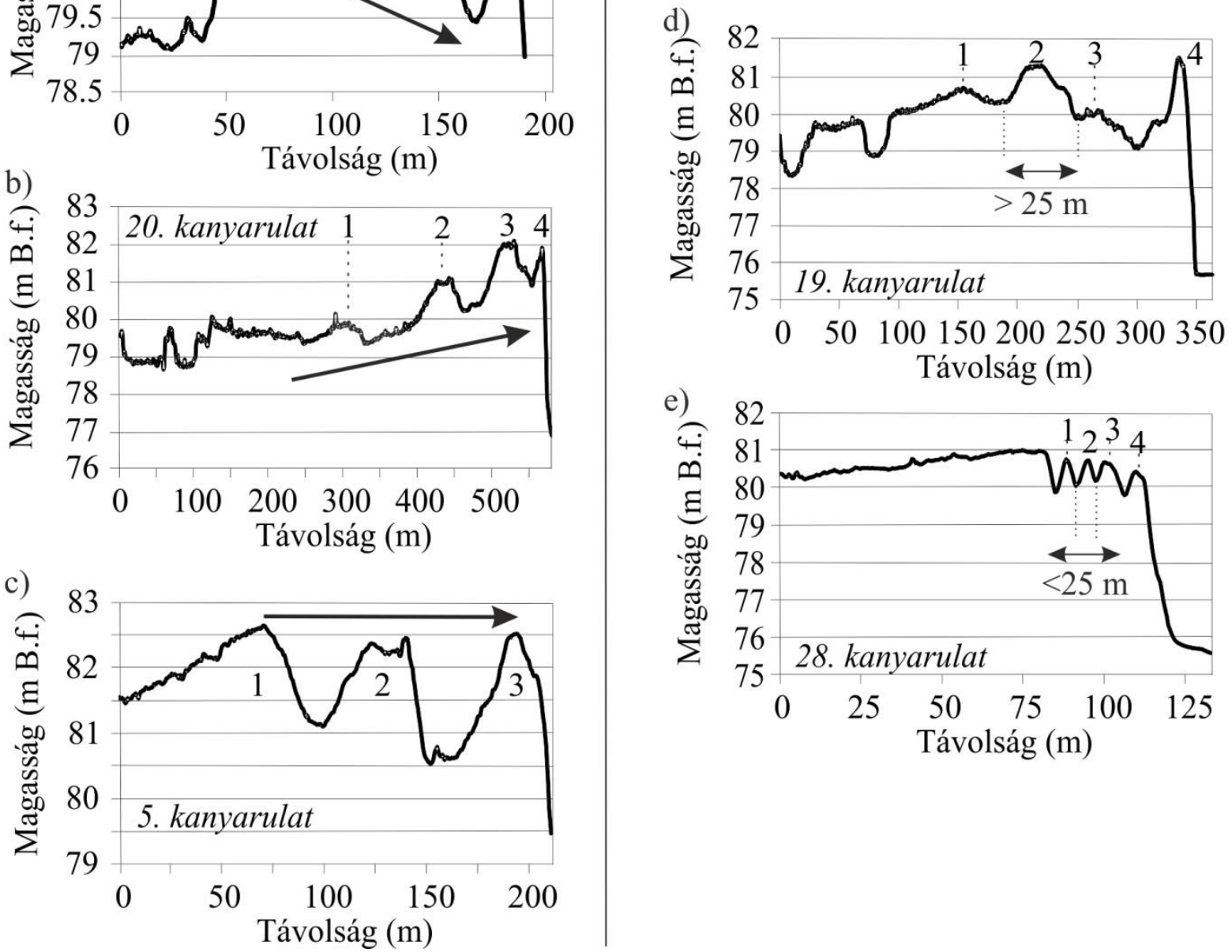

51. ábra. Az övzátony-sorok típusai magassági és szélességi viszonyaik alapján. a: alacsonyodó övzátonyok, $b$ : magasodó övzátonyok,c: változatlan magasságú övzátonyok, $d$ : széles övzátonyok, e: keskeny övzátonyok

A második típus esetében az egyes övzátonyok magassága fokozatosan nö a meder irányában (51b. ábra). Ez a típusú övzátony-fejlődés a kanyarulatok 39\%-ánál figyelhető meg (13 db). Az övzátony-tagok magasságnövekedése átlagosan 1,2 m, de igen széles skálán, 0,23,4 m között mozog. Ha elosztjuk ezt a növekedést az övzátony-sorok tagszámával, akkor ez az érték 0,2-0,6 m/tag között változik, azaz hasonló a tagok közötti magasságnövekedés a csökkenő magasságú övzátony-sorokra jellemző tagok közötti változáshoz $(0,2-0,8 \mathrm{~m} / \mathrm{tag})$. Azt gondolom, hogy az övzátony-tagok magasságának növekedése utalhat:

- a kanyarulatvándorlás lassuló ütemére, hiszen így az övzátonyok épülésére egyre hosszabb idő áll rendelkezésre, és ezáltal a formák egyre magasabbakká válnak. A partelmozdulását lassulását okozhatja a kötöttebb mederanyagú (iszap és agyag) rétegek elérése is, amely eredményeképpen a meder jobban ellenáll az oldalazó 
eróziónak és a bevágódásnak (Thorne 1991). De véleményem szerint meghatározó szerepe lehet a kanyarulatok külső oldalán épített partbiztosításoknak is, amelyek a kanyarulatvándorlás lassulását és/vagy megállását eredményezik, hasonlóan a kötött mederanyaghoz;

- az övzátonyt felépítő fenék-és lebegtetett hordalék hozamának növekedésére, mivel ha a forma kialakulásához rendelkezésre álló idő változatlan, akkor ilyen peremfeltételek mellett a forma felszínén egyre nagyobb mennyiségü hordalék rakódik le, ami az övzátonyok egyre magasabbá válását eredményezi.

A kanyarulatok 15\%-a (5 db) esetében az övzátony-sorokat alkotó tagok magassága nem változott (51c. ábra): a közöttük lévő magasságkülönbség 15-20 cm-en belül volt, és nem mutattak trend-szerü alacsonyodást vagy magasodást. Ez a helyi befolyásoló tényezök szerepére (például a medret felépítő üledékek változatossága, partbiztosítások, part menti sürübb növényzet) hívja fel a figyelmet, így a hordalékhozam változása a Tiszán nem lehet ok, hiszen az a formák magasságának változását egységesen eredményezné a teljes vizsgált folyószakasz mentén.

A kanyarulatok fennmaradó 9\%-a (3 db) mentén csupán egy övzátony alakult ki, így övzátony-sorokról esetükben nem beszélhetünk, tehát fejlödésük irányára sem lehet következtetni. Ezek a kanyarulatok azokon a kiegyenesített szakaszokon találhatóak, ahol a kanyarulatfejlődés csupán a szabályozások után tudott megindulni, így a rövid idő, illetve a meder közepén futó sodorvonal még nem tette lehetővé a többtagú övzátony-sorok kialakulását.

$\mathrm{Az}$ egyes típusok térbeli elhelyezkedésére jellemző (52. ábra), hogy az alacsonyodó övzátonysorok kétharmada a jobb parti hullámtéren található, tehát a kelet felé vándorló kanyarulatok mentén. Ezzel szemben, a meder irányába emelkedő övzátony-sorok kétharmada a bal parti hullámtéren található, tehát a nyugat felé fejlödő kanyarulatok övzátony-sorai magasodnak inkább. Véleményem szerint ennek egyik oka lehet, hogy a Tisza két oldalán elöforduló üledékek kötöttsége eltérö. A paleo-medrek többsége a Tiszától keletre maradt fenn, ami arra utal, hogy a folyó folyamatosan nyugatra vándorol. A nyugati oldalon azonban számos szakaszon a folyó nagyon közel fut a dunai hordalékkúp pereméhez, illetve idősebb és jóval kötöttebb üledékek építik fel a felszínt (Hernesz 2015), így azokat a Tisza nehezebben mossa el. Ennek eredményeként a nyugatra vándorló kanyarulatok belső oldalán magasodó övzátonyok találhatóak. A másik ok, hogy ezen kanyarulatok esetében egyre magasabb övzátonyok fejlődnek, az lehet, hogy mivel a nyugati oldalon a meder közel fut az árvízvédelmi töltéshez, így gyakoribb a jobb part laterális eróziójának partbiztosításokkal való megállítása. Hatásukra lassul, majd leállhat a kanyarulat belső oldalán az övzátonyok oldalirányú fejlődése (Kiss et al. 2018), így azok egyre magasabbá válnak.

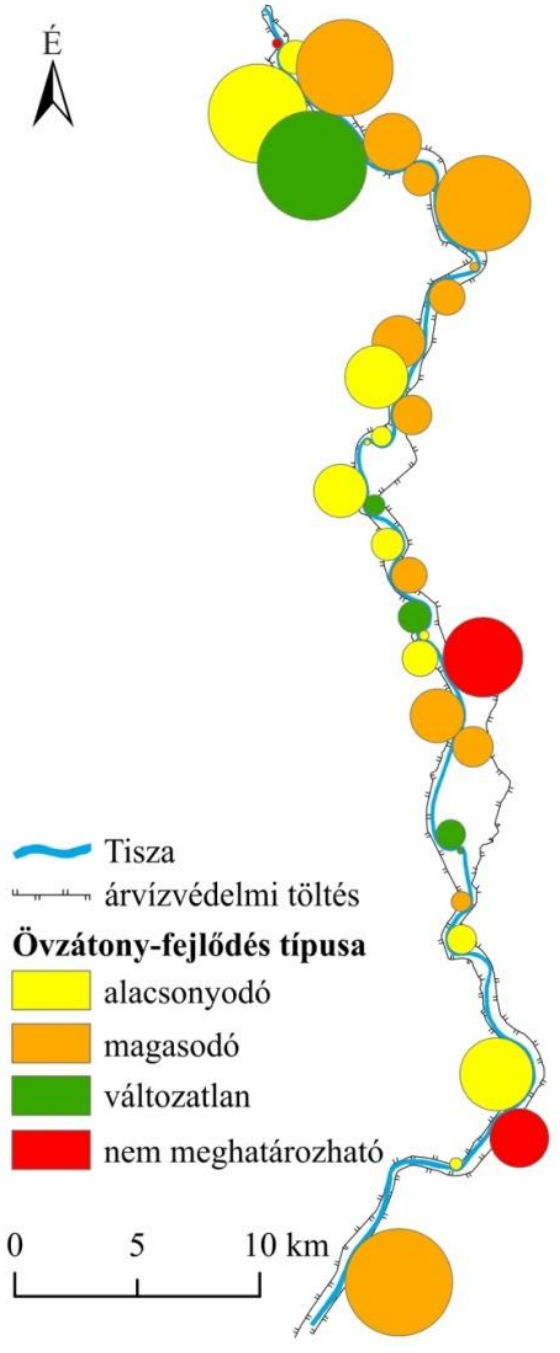




\section{B) Övzátony-sorok típusai szélességük alapján}

Az övzátony-tagok szélessége alapján az övzátony-sorokat két fö típusba lehet sorolni (51. ábra). A kanyarulatok 21\%-ánál az övzátony-sorokat széles (> $25 \mathrm{~m}$ ) övzátonyok alkotják (51d. ábra), míg 39\%-ánál keskeny ( $<25 \mathrm{~m}$ ) formák alakultak ki (5le. ábra). A többi kanyarulat esetében (40\%) azonban e két típus keveredése figyelhető meg, tehát az egyes övzátony-sorok fejlödése során az övzátonyok kezdetben nagyon szélesek voltak és idővel keskenyedtek, vagy pedig felváltva találhatók az övzátony-soron belül keskenyebb és szélesebb tagok is.

Véleményem szerint az övzátony-sorokat alkotó egyes tagok szélessége összefügg a kanyarulatvándorlás sebességével, illetve a külső ív parteróziójának ütemével. Ha a parterózió gyors, akkor a dinamikusan kiszélesedő mederben lehetőség van az újabb és újabb övzátonyok kialakulására, ami a keskenyebbé válásukat eredményezheti. Ugyanakkor a széles övzátonyok olyan idöszakra utalhatnak, amikor vagy hirtelen kiszélesedett a meder és az övzátony lassan fejlődve fokozatosan leszükítette a medret, vagy amikor a nagyon lassú és folyamatos partelmozdulással az övzátony-épülés lépést tudott tartani, és így a meder szélessége állandó maradt.

\subsubsection{Az egyes övzátonyok magasságának és szélességének jellemzői}

\section{A) Relatív magasság alakulása}

Az Alsó-Tisza egyes kanyarulataihoz tartozó övzátonyok tagjainak magassága folyásirányban nem trendszerüen változik (53. ábra), bár a terület északi és déli részén, ahol a meder kevésbé kanyargósabb, ott az övzátony-sorokat alkotó tagok átlagos magassága hasonló. A mintaterület északi részén a 2. sz. kanyarulattól a 7.-ig (Körös-torok) az egyes övzátonysorokat alkotó tagok átlagmagassága hasonló (1,5-2,1 m). A Körös-toroktól délre (8-19. sz. kanyarok) azonban részben a meder kanyargósabbá válása, részben pedig a hullámtér kiszélesedése miatt az övzátonyok átlagmagassága kanyarulatonként nagyon változó, nem különíthetők el olyan szakaszok, ahol a formák magassága hasonló lenne. A 9. sz. kanyarulatnál például az övzátonyok átlagmagassága $2,8 \mathrm{~m}$, a 10 . sz. kanyarulat mentén már $4,1 \mathrm{~m}$, a 11 . sz. kanyarulat esetében pedig ismét lecsökken, 3,3 m-re. A Tisza következő szakaszán (20-25. sz. kanyarok) a meder ismét kevésbé kanyargós. Az itt lévő kanyarulatokban az övzátonyok átlagmagassága 2,5-3,1 m, amely alól csak az Ányási-kanyarulat kivétel, ahol az övzátonyok átlagmagassága csupán $0,8 \mathrm{~m}$. Ezt követően, a 26. sz. kanyarulattól egészen a magyar-szerb határig az övzátonyok átlagmagassága némileg lecsökken (2,3-2,6 m-re), amely alól kivételt képeznek a 30 és a 34. sz. kanyarulatok, ahol jóval magasabb övzátony-sorok formálódtak (átlagosan 3,2 m és 3,8 m).

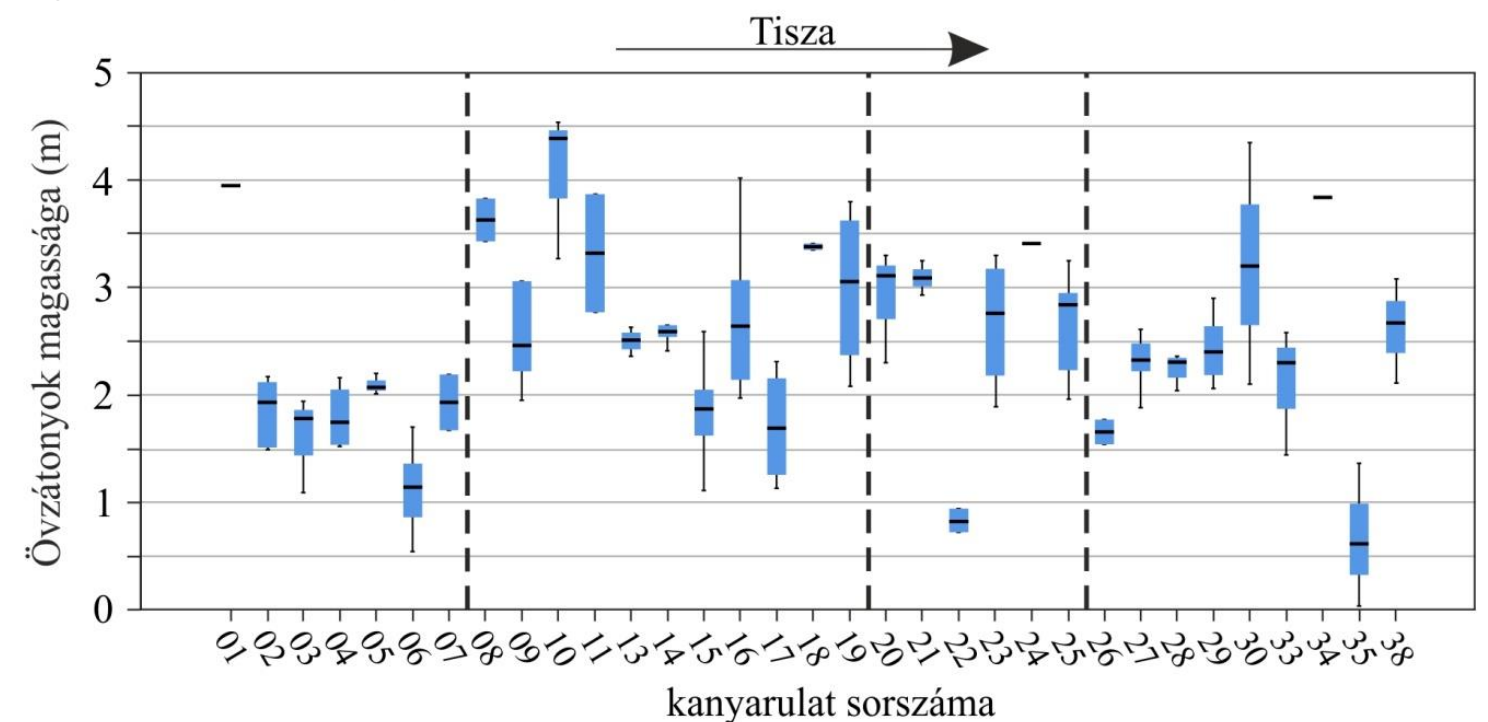

53. ábra. Az övzátony-sorokon belül az egyes övzátonyok magassági jellemzői kanyarulatonként 


\section{B) Az utolsó, aktív övzátonyok magassági viszonyai}

$\mathrm{Az}$ egyes kanyarulatokon belül megfigyelhető az övzátony-sorokat alkotó utolsó (legfiatalabb) tag magasságának hirtelen megemelkedése (54. ábra). Ez a jelenség a kanyarulatok 70\%-ára jellemző, de a csökkenő magasságú övzátony-sorok esetében ez jóval egyértelmübb, hiszen itt az utolsó övzátony-tag emelkedése jóval látványosabb és eltér a megszokott övzátonyfejlődési iránytól. Azokban a csökkenő magasságú övzátony-sorokban, ahol megfigyelhető az utolsó övzátony-tag emelkedése, a magasságnövekedés igen változó ütemü (0,6-2,3 m).

A növekvő magasságú övzátony-sorok esetében az utolsó tag intenzívebb magasodása azonban kisebb mértékü és nehezebben elkülöníthető, hiszen az övzátonyok magasságának növekedése e típus esetén az övzátony-sor fejlődésének alapvető jellemzője. Azért, hogy a növekvő tendenciát mutató övzátonyok közül ki lehessen szürni, hogy melyek azok az övzátonysorok, amelyek utolsó tagja egyértelmüen emberi behatásra változott meg, kiválogattam azokat, melyek esetében az utolsó tag növekedése meghaladja az egész övzátony-sorra jellemző átlagos magasság-növekedést. Így a növekvő magasságú övzátony-sorok (13 db) közül összesen 8 esetében figyelhető meg intenzívebb magasságnövekedés (átl: $1,2 \mathrm{~m}$ ), de vannak olyan kanyarulatok, amelyek esetében ez a $3 \mathrm{~m}$-t is meghaladja.

Azokban az övzátony-sorokban, ahol az egyes tagok magassága a meder irányában változatlan, nem figyelhető meg az utolsó tag magasságának megemelkedése, így ez a jelenség csak az alacsonyodó és a magasodó övzátony-sorokat érinti.

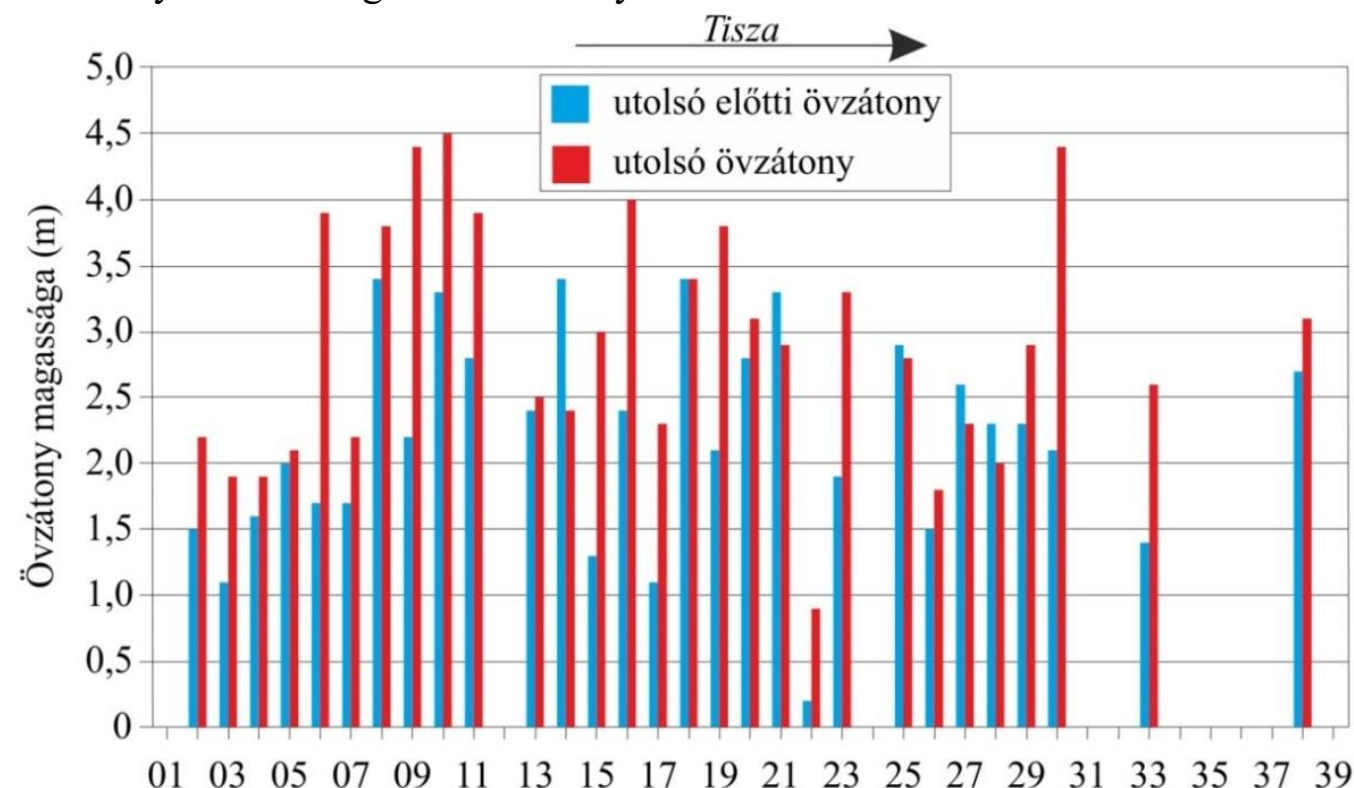

Kanyarulat sorszáma

54. ábra. Az övzátony-sorokat alkotó utolsó elötti és utolsó tag magassága kanyarulatonként az Alsó-Tisza mentén

\section{C) Szélesség alakulása}

Az övzátony-sorokat alkotó tagok szélességi viszonyainak térbeli változása a magassági viszonyok változásához hasonló (55. ábra). A Körös-torkolatáig (1-7. sz. kanyarulatok) az övzátonyok viszonylag keskenyek (átl: $12-20 \mathrm{~m}$ ), amely alól kivételt képeznek az 5-6. sz. kanyarulatok övzátony-sorai, ahol jóval szélesebb, átlagosan $36-58 \mathrm{~m}$ széles övzátonyok fejlődtek. A 8. és 13. sz. kanyarulatok között az előző szakaszhoz képest szélesebb (átl: 31-43 m), de a szakaszon belül viszonylag hasonló szélességü övzátonyok alakultak ki. Az ezt követő szakaszon (14-22. sz. kanyarulatok) az övzátony-sorokon belül nagyon változó a formák szélessége, ugyanis ez a legkanyargósabb szakasz az Alsó-Tiszán és nagyon változatos a kanyarulatok geometriája és fejlödése is. A 23-30. sz. kanyarulatok között nagyon keskeny (8-26 m) övzátonyok képződtek. Az Alsó-Tisza mentén itt van a meder csaknem teljesen kiegyenesítve, és a hullámtér is egységesen szük. Végül a mintaterület utolsó alvízi szakaszán (33-38. sz. 
kanyarulatok) az övzátony-tagok szélesebbé (átl: 38-42 m) váltak és a kanyarulatok között is csupán kis eltérések tapasztalhatók.

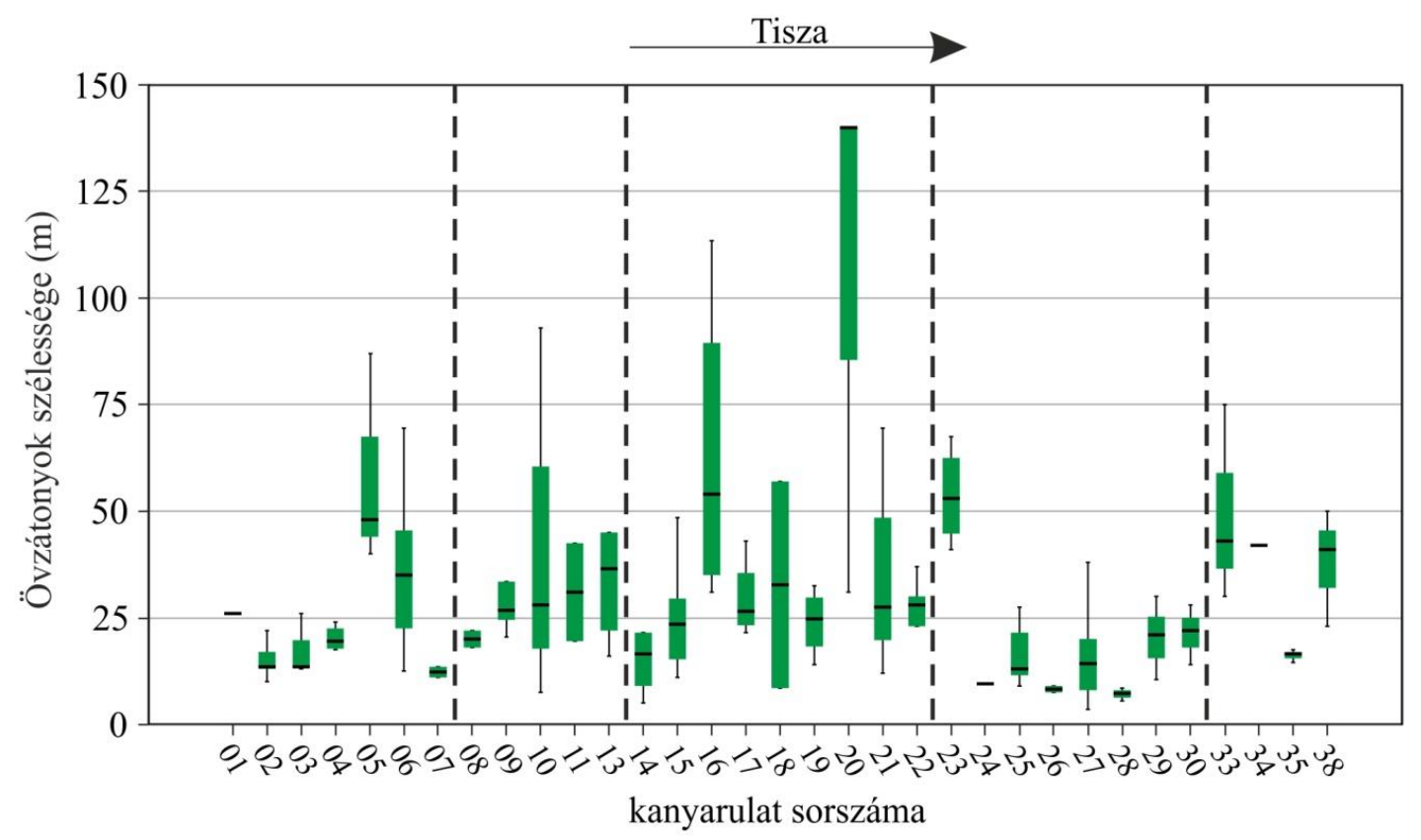

55. ábra. Az övzátony- sorokon belül az egyes övzátonyok szélességi jellemzői kanyarulatonként

D) Az utolsó, aktív övzátonyok szélességi viszonyai

Ha az egyes kanyarulatokon belül vizsgáljuk az övzátonyok szélességét, megfigyelhető azok folyamatos keskenyebbé válása, azaz rendre a legfiatalabb, aktív övzátony a legkeskenyebb (56. ábra). Ezen övzátony-soron belüli legutolsó formák átlagszélessége a teljes Alsó-Tisza mentén mindössze $19 \mathrm{~m}$, kanyarulatonként azonban igen változó képet mutat, hiszen a formák szélessége 4 és $42 \mathrm{~m}$ között változik. Az egyes kanyarulatokban a formák szélességének csökkenését jól mutatja az utolsó tag szélességének viszonya a teljes övzátony-sort alkotó tagok átlagszélességéhez. A vizsgált kanyarulatok 51\%-a mentén megfigyelhető, hogy az utolsó tagok szélessége kisebb, mint a teljes övzátony-sort alkotó tagok átlagszélessége, amelynek értéke kanyarulatonként 2 és $35 \mathrm{~m}$ között változik, tehát az övzátonyok szélességének csökkenése kanyarulatonként nem egyenlő mértékben zajlik.

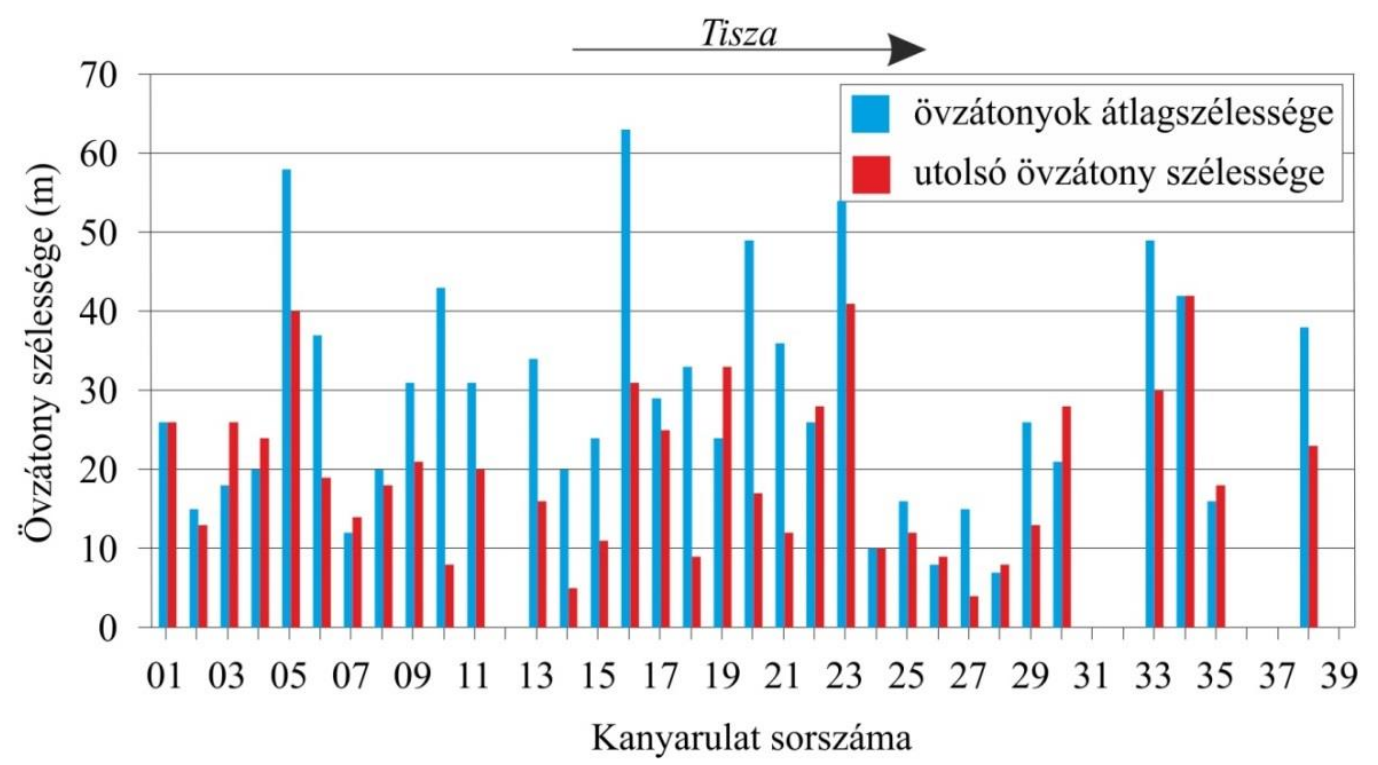

56. ábra. Az övzátony-sorokat alkotó tagok átlagszélessége és a legutolsó utolsó tag szélessége kanyarulatonként az Alsó-Tisza mentén 


\subsubsection{Az övzátonyok méretét befolyásoló tényezök}

A fentebb leírtak azt tükrözik, hogy az övzátony-sorok morfológiája kanyarulatonként jelentősen változik, folyásirányban nem mutat jellegzetes trendet, ezért a következőkben azt vizsgáltam meg, hogy az övzátony-sorok morfometriai paramétereit milyen tényezők befolyásolhatják.

\section{A) Kanyarulatvándorlási típusok hatása az idösebb övzátonyok magasságára és szélességére}

Mivel az áthelyeződő kanyarulatok típusába csupán egyetlen egy tartozik (22. sz. Ányásikanyarulat), ezért az elemzéseket a megnyúló és az elforduló kanyarulatokra végeztem el. A kanyarulatfejlődési típusok övzátonyok morfológiájára gyakorolt hatását az egész övzátony-sor összes tagjára vonatkozóan vizsgáltam, hiszen az egyes típusok hosszú fejlödés során alakultak ki, amelyek hatása az idősebb övzátonyokon is tükröződhet. A legfiatalabb tagokat azonban kihagytam, mivel ezek esetében jelentősebb lehet az emberi beavatkozás (partbiztosítások) hatása.

Az eredmények azt mutatják, hogy az elforduló kanyarulatok esetében átlagosan 2,3 m (1,13,3 m) magas övzátonyok találhatóak, míg a megnyúló kanyarulatok esetében pedig átlagosan 2 m (0,5-3,5 m) magas formák alakultak ki, tehát az elforduló kanyarulatok mentén átlagosan 0,3 m-rel magasabbak az övzátony-formák (57. ábra). Bár ez a különbség a két kanyarulatvándorlási típus között nem túl határozott, hiszen az adatok azt mutatják, hogy a megnyúló kanyarulatok esetében elöfordulnak nagyon magas ( $3 \mathrm{~m}$-t meghaladó) formák is (pl. a Mindszent környéki 1920. sz. kanyarulatok). Véleményem szerint ezen kanyarulatok esetében meghatározható lehet a mederanyag kötöttsége, hiszen a kötöttebb mederanyag miatt lassabb a partemozdulás $(<1 \mathrm{~m} / \mathrm{e} v$ volt már az 1800-as évek végén is), amely az övzátonyok magasságának növekedését okozhatja.

Az övzátonyok szélessége és a kanyarulatvándorlási típus közötti összefüggés azt mutatja, hogy mind a két típusú kanyarulat mentén nagyon hasonló az övzátony-sorokat alkotó tagok átlagos szélessége (57. ábra). Megnyúló kanyarulatok mentén átlagosan 33 m (6-93 m), elforduló kanyarulatok esetében pedig átlagosan 27 m (4-114 m) szélesek az övzátonyok.

$\mathrm{Az}$ általam kapott eredmények ellentmondanak a szakirodalomban található magyarázatoknak, ugyanis például Strick et al. (2018) szerint az elforduló kanyarulat esetében jóval szélesebb övzátonyok alakulnak ki, mivel a kanyarulat rotációs mozgása növeli az övzátony szélességét azáltal, hogy a forma saját magára fordul vissza. Az Alsó-Tisza kanyarulatai esetében azonban ez a megállapítás nem bizonyítható, hiszen mind a megnyúló és az elforduló kanyarulatok mentén is megfigyelhetők hasonló szélességü övzátonyok. Véleményem szerint az utóbbi 250 évben tapasztalható mederszükülés hatása felülírja a kanyarulatvándorlás típusának hatását, emiatt lehetséges az, hogy mind a megnyúló és az elforduló típusú kanyarulatok mentén is hasonló szélességü, ugyanakkor egyre keskenyedő övzátonyok formálódtak.
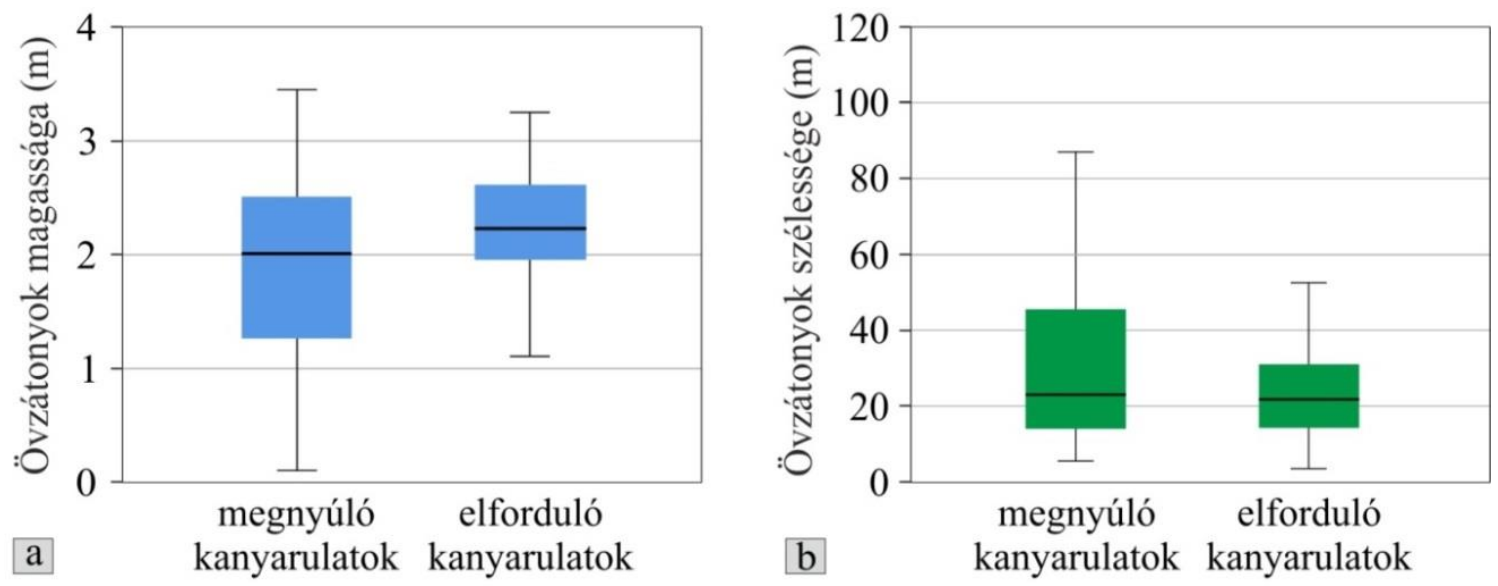

57. ábra. Az egyes kanyarulatvándorlási típusok hatása az idösebb övzátonyok magasságára (a) és szélességére (b). 


\section{B) A görbületi sugár hatása az aktív övzátonyok magasságára és szélességére}

A kanyarulatok görbületi sugarának $\left(\mathrm{R}_{\mathrm{c}}\right)$ hatását csak az övzátony-sorokat alkotó legutolsó tagokra vonatkozóan vizsgáltam, hiszen csak az utolsó övzátonyhoz tartozó (jelenlegi) meder görbületi sugara állapítható meg pontosan, hiszen minden egyes övzátonyt formáló akkori meder partéleinek futása nem mindig ismert.

Az övzátony-sorok utolsó tagjának morfológiai tulajdonságai és a kanyarulatok görbületi sugara között összefüggést csak az elforduló típusú kanyarulatok esetében találtam (58. ábra). Az eredmények azt mutatják, hogy a legutolsó övzátonyok magassága logaritmikusan változik a görbületi sugárral $\left(\mathrm{R}^{2}=0,74\right)$. Azaz minél nagyobb a görbületi sugár, az övzátony-forma annál alacsonyabb, hiszen például $R_{c}=150-230$ m esetén 4-4,4 m magas övzátonyok képződtek, míg $\mathrm{R}_{\mathrm{c}}=1380$ m esetén már csak $2,8 \mathrm{~m}$ az övzátony magassága. Ezek között egy kivétel van, a 30. sz. kanyarulat, ahol 749 m-es görbületi sugár mellett igen magas $(4,4 \mathrm{~m})$ forma fejlödött.

Az övzátonyok szélessége esetében is a fentiekhez hasonló kapcsolat figyelhető meg $\left(\mathrm{R}^{2}=0,72\right)$, azaz minél kisebb a görbületi sugár annál szélesebb az övzátony (58. ábra). Például egy 152 m-es görbületi sugarú kanyarulat mentén $31 \mathrm{~m}$ széles övzátony formálódott, míg $\mathrm{R}_{\mathrm{c}}=1380 \mathrm{~m}$ esetén $11,5 \mathrm{~m}$ széles az övzátony-forma. Itt is a 30 . számú kanyarulat a kivétel, ahol 750 m-es $R_{c}$ mellett 21,3 m széles övzátony alakult ki.

Véleményem szerint annak oka, hogy kisebb görbületi sugarú kanyarulatok mentén magasabb és szélesebb a legutolsó övzátony az lehet, hogy a kis görbületi sugár miatt a sodorvonal közelebb helyezkedik el a külső ívhez, ezért a kanyarulat belső ívén gyorsabb a hordalék felhalmozódása (Nanson és Hickin 1983). Így a belső íven nagyobb mennyiségü hordalék rakódik le, amelyet tovább fokoz a kanyarulat fejlödési típusa, mivel az elforduló jelleg miatt az övzátonyok saját magukra fordulnak vissza, amely növeli a formák magasságát és szélességét (Strick et al. 2018). Tehát ebben az esetben igaz Strick et al. (2018) megállapítása, miszerint az elforduló kanyarulatok mentén magasabb és szélesebb övzátonyok formálódnak, mint a megnyúló típusú esetén, de ez nem kizárólag a kanyarulatvándorlási típus függvénye, hanem véleményem szerint jelentős szerepe van a kanyarulatok görbületi sugarának is.
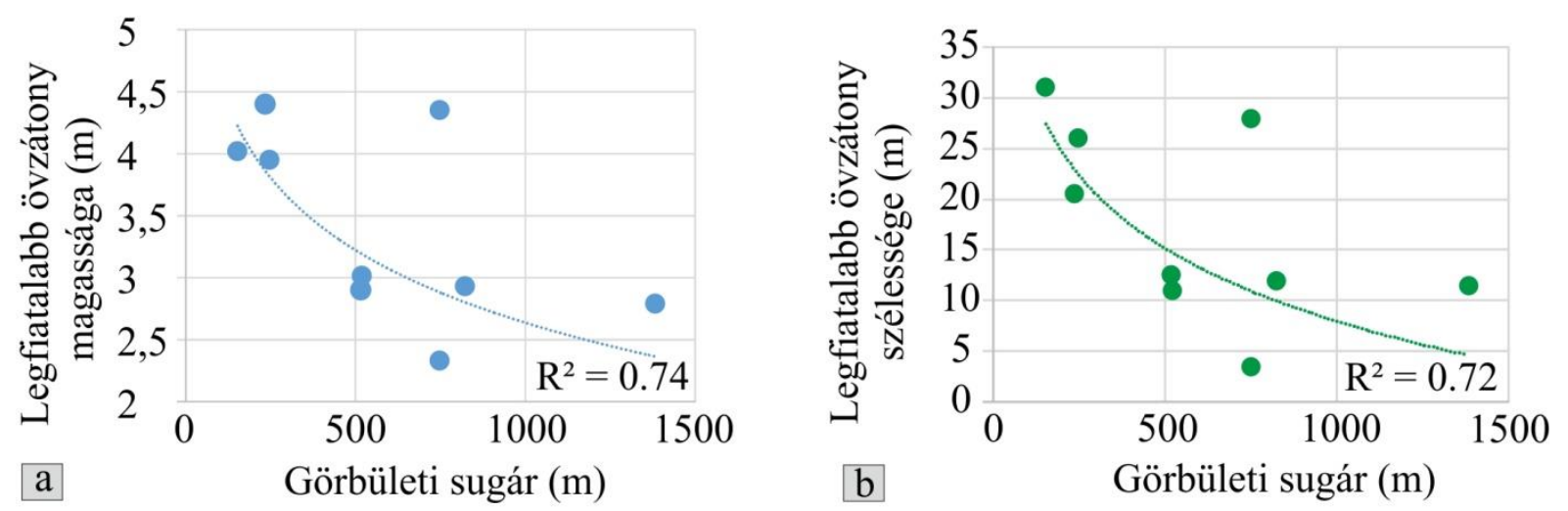

58. ábra. A görbületi sugár hatása a legfiatalabb övzátonyok magasságára (a) és szélességére (b) az elforduló kanyarulatvándorlási típus esetében

\section{C) A mederszélesség és a partbiztositások hatása az övzátonyok szélességére}

Mivel a mederszélesség csökkenése és a partbiztosítások kiépítése szoros kapcsolatban áll egymással, így az övzátonyok morfológiájára gyakorolt hatásukat egyszerre mutatom be.

A mederszélesség hatásának vizsgálatához a kanyarulatok mentén megnéztem, hogy az egyes mederfelmérések közötti időszakban hány övzátony képződött, és azok szélességének átlagát összevetettem az időszak végén jellemző mederszélességgel. Tehát például az 1976 és 
2014 között képződött övzátonyok szélességét a 2014-ben mért mederszélességgel vetettem össze, hiszen ezekre az 1976. évi felméréskor jellemző mederszélesség nem lehetett hatással, mivel a formák csak azután képződtek.

Az Alsó-Tiszán az 19. század végétől a meder folyamatosan szükül, és ezt a változást az övzátonyok szélessége is tükrözi (59. ábra). Míg az 1783. évi felmérés idején a meder széles volt (átl: $197 \mathrm{~m}$ ) és a hozzá kapcsolódó övzátonyok átlagos szélessége $68 \mathrm{~m}$ volt, addig napjainkra a meder 159 m-re szükült. Emiatt az övzátonyok is folyamatosan keskenyedtek, hiszen 2014-ben átlagszélességük már csak 19 m volt. Kivételt képez az 1861 és 1890 közötti időszak, amikor a szabályozások hatására kiszélesedett a meder (175 m-ről 192 m-re) és több hely állt rendelkezésre az övzátonyok formálódására is, így ezek átlagszélessége ebben az időszakban $48 \mathrm{~m}$ volt.

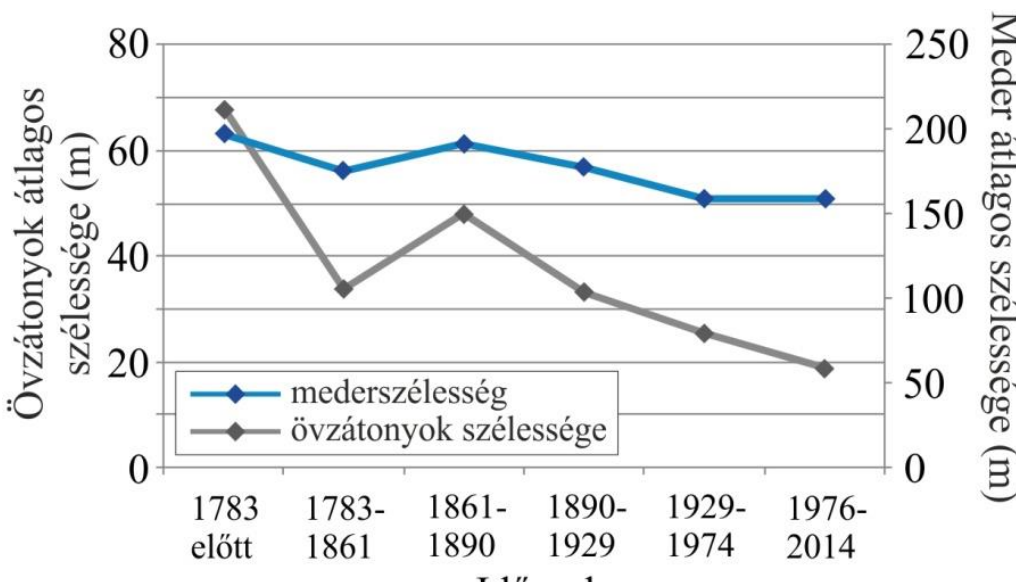

Időszak

59. ábra. Az övzátony-sorokat alkotó tagok átlagos szélességének változása és a mederszélesség alakulása a 18. század végétöl

A vizsgált időszakban, tehát a 18. század végétől tapasztalható mederszélesség-változás több okra vezethető vissza. Az 1783 és 1861 között jellemző intenzív mederszükülés abból adódhat, hogy a két felmérés eltérő vízállások mellett készült. Az 1861. évi felmérés során hosszan tartó kisvizes időszak állhatott fent, ugyanis ez idő tájt csapadékszegény időszak volt jellemző az országban (Rácz 1999). Az alacsony vízállást a térképezésen jelölt övzátonyok is bizonyítják. Az 1861 utáni időszakban a meder átmenetileg kiszélesedett, hiszen a szabályozások során létrehozott vezérárkokat a folyónak először ki kellett szélesítenie, így a főmeder átlagszélessége megnőtt. Ezt követően azonban a meder folyamatos szükülésnek indult, amelynek oka egyrészt a kanyarulat-átvágások következtében megnőtt esés, amely a folyó munkavégző-képességének növekedését is eredményezte. Ennek következtében a meder bevágódott és szélessége lecsökkent (Károlyi 1960, Ihrig 1973). Az 1930-as évek óta a meder szélességének csökkenése azonban már a partbiztosítások kiépítésével hozható összefüggésbe, amelyeket a kanyarulat-átvágásokat követően kezdtek meg kiépíteni (az elsőt 1886-ban), és azóta csaknem az összes kanyarulat partbiztosított. A partbiztosítások hatására megállt a külső ív oldalazó eróziója, de a kanyarulatvándorlás - ha lassuló ütemben is - fennmaradhatott a meder szükülése miatt, hiszen a belső ív épülése tovább zajlott. A kanyarulatok külső ívének elmozdulása híján megváltozott az övzátonyok épülése is. A kanyarulatok $70 \%$-ánál megfigyelhető, hogy az övzátony-sorok legutolsó tagjának magassága jóval nagyobb, mint az azt megelőzők. Ez a partbiztosítások kiépítésének eredménye lehet, hiszen a szükülö mederben korlátozottá vált vagy megállt az övzátonyok oldalirányú fejlődése, hiszen míg az 1929-1976 közötti időszak az Alsó-Tiszán a belső ív elmozdulása átlagosan 0,7 m/év volt, addig 2014-re ez 0 m/évre csökkent. Ennek eredményeként az oldalirányú felhalmozódást felváltotta a hordalék vertikális akkumulációja, így az övzátony-formák egyre magasabbá válnak. 
Jelenleg azoknál a kanyarulatoknál, ahol a külső íven van partbiztosítás, az utolsó övzátony magassága átlagosan 3,1 m, szélessége pedig átlagosan $19 \mathrm{~m}$ (60. ábra). Ezzel szemben ott, ahol nincs kiépítve partbiztosítás a legfiatalabb övzátonyok némileg alacsonyabbak (átlagosan 2,5 m) és szélesebbek (átlagosan $22 \mathrm{~m}$ ). Az övzátonyok magasabb létéhez hozzájárulhat az egyre sürübbé váló part menti növényzet is (Kiss et al. 2019), amely megakadályozza, hogy a hordalék a hullámtér belsö területei felé eljusson, így az a part menti zónában rakódik le.

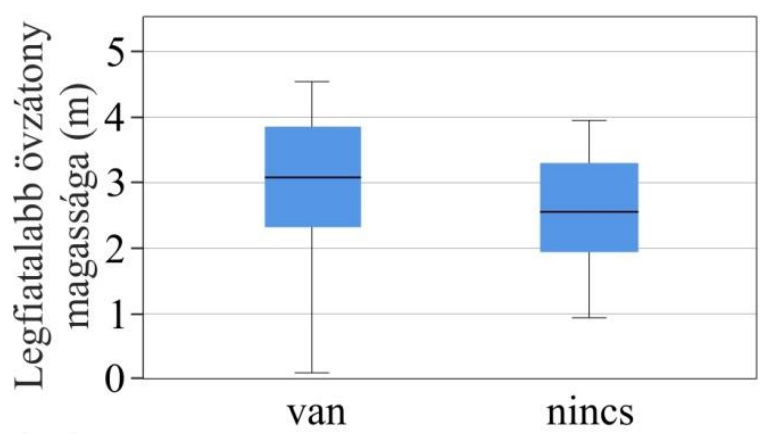

a partbiztosítás partbiztosítás

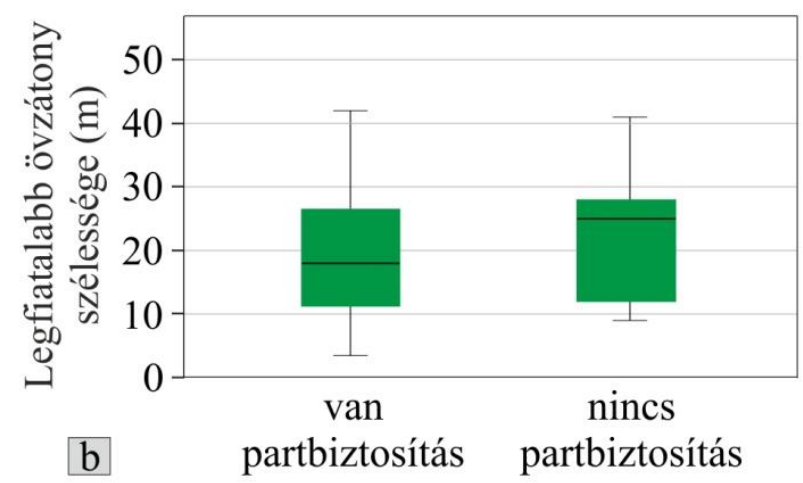

60. ábra. A partbiztositások hatása az övzátony-sorokat alkotó legfiatalabb tagok magasságára (a) és szélességére (b)

\subsubsection{Az övzátony-sorokkal szemben formálódó folyóhátak morfológiai tulajdonságai}

Az elforduló és megnyúló kanyarulatfejlödési típusokon belül megvizsgáltam, hogy az övzátonyokkal szemben fejlődő folyóhátak morfológiája hogyan alakul, hiszen az övzátonyfelszínen bekövetkező változások (partelmozdulás lassulása) hatással lehetnek a kanyarulat túloldalán fejlődő folyóhátak fejlődésére is. Ebben az esetben viszont fontos az is, hogy milyen típusú az adott övzátony-sor magasságviszonyainak alakulása (alacsonyodó vagy magasodó).

\section{A) Övzátony-fejlődési típusok és a szemben levő folyóhátak morfológiája közötti kapcsolat}

Ha csak az övzátony-fejlődési típusokon belül elemezzük a folyóhátak morfológiai tulajdonságait, akkor az tapasztalható, hogy közöttük csak minimális eltérés van (61. ábra). A meder felé csökkenő magasságú övzátony-sorokkal szemben némileg magasabb folyóhátak fejlődnek, magasságuk átlagosan 3,9 m (2,5-4,8 m), míg a magasodó övzátony-sorokkal szemben lévők alacsonyabbak, átlagosan 3,6 m (2,6-4,5 m) magasak. Ugyanakkor szélességi viszonyaik már különbözőbbek, mivel alacsonyodó övzátony-sorokkal szemben szélesebbek a folyóhátak (átl: $227 \mathrm{~m}$; 40-460 m), a magasodó övzátony-sorokkal szemben viszont keskenyebbek (átl. 65 m; 25-310 m).

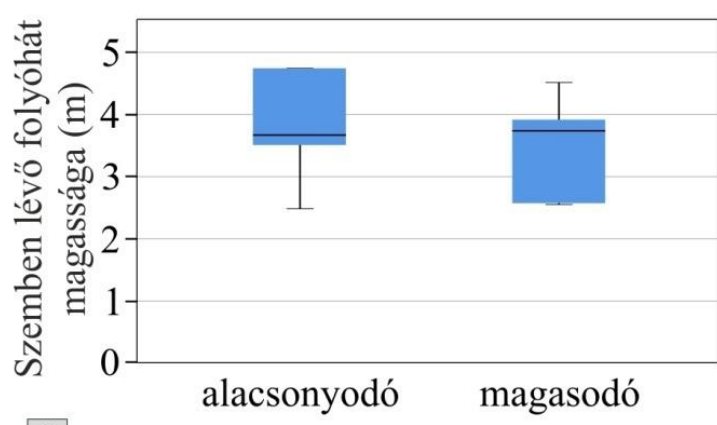

Övzátony-sor fejlődési típusa

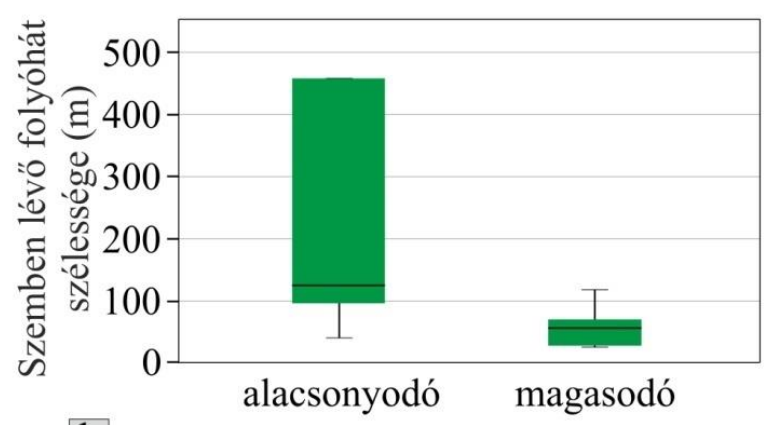

b Övzátony-sor fejlődési típusa

61. ábra. Az alacsonyodó és magasodó övzátony-sorokkal szemben fejlödö folyóhátak magassága (a) és szélessége (b) 


\section{B) Kanyarulatvándorlási típusok és a folyóhátak morfológiája közötti kapcsolat}

Azonban a két övzátony-fejlődési típus és a folyóhátak közötti összefüggések markánsabbá válnak, ha ugyanezt a kanyarulatvándorlási típusokra vizsgáljuk meg. A megnyúló és az elforduló kanyarulatok mentén az alacsonyodó illetve a magasodó övzátonysorokkal szemben fejlődő folyóhátak magassága között jelentős különbségek vannak, amely szintén a kanyarulatok eltérő görbületi sugarával magyarázható (62. ábra). A megnyúló kanyarulatok rendre nagy görbületi sugarúak is, és övzátony-soraikkal szemben lévő folyóhátak magassága hasonló, függetlenül attól, hogy magasodó vagy alacsonyodó övzátony-sorokról van szó, ugyanis alacsonyodó övzátonyokkal szemben átlagosan 3,3m (2,5-3,9m), míg a magasodó övzátonyokkal szemben pedig szintén átlagosan 3,3 m (2,6-4,5 m) magasak. Ugyanakkor az elforduló kanyarulatok mentén (amelyek kisebb $\mathrm{R}_{\mathrm{c}}$-vel rendelkeznek) a két típus között markánsabb a különbség, hiszen az alacsonyodó övzátonyokkal szemben átlagosan 4,5 m (3,54,8 m) magas folyóhátak fejlődtek, míg a magasodó övzátony-sorokkal szemben alacsonyabb, átlagosan 4 m (3,8-4,5m) magas folyóhátak formálódtak.

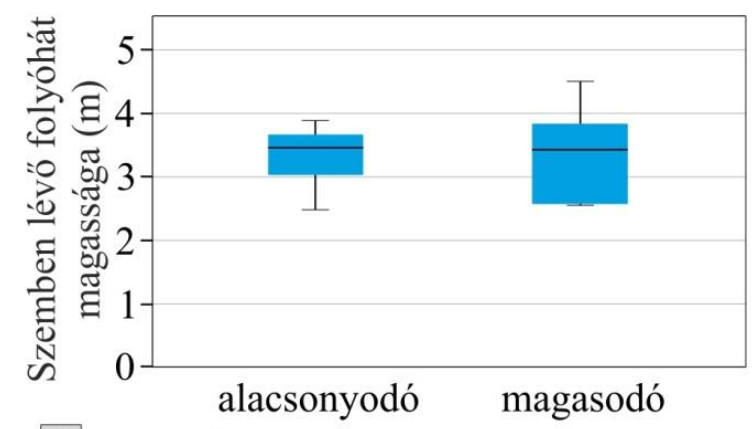

a

Övzátony-sor fejlődési típusa

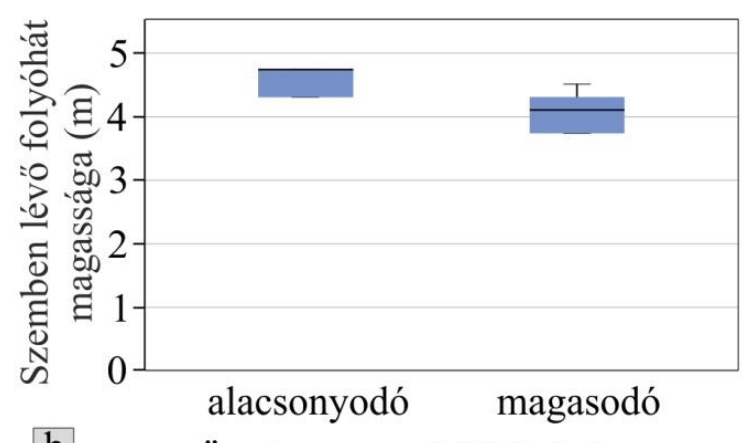

b

62. ábra. Az alacsonyodó és magasodó övzátony-sorokkal szemben fejlődő folyóhátak magassága megnyúló (a) és elforduló (b) kanyarulatok esetén

Az övzátony-felszínekkel szemben fejlődő folyóhátak szélessége némileg eltérő összefüggést mutat, mint ami a folyóhátak magassága esetében látható (63. ábra). A megnyúló kanyarulatok mentén az alacsonyodó övzátony-sorokkal szemben kétszer olyan szélesek a folyóhátak (átl: 120 m; 40-215 m) mint a magasodó övzátony-sorokkal szemben (átl: 64 m; 25$310 \mathrm{~m}$ ). Az elforduló kanyarulatok mentén azonban a két övzátony-fejlődési típus közötti különbség még határozottabb, hiszen az alacsonyodó övzátony-sorokkal szemben ötször olyan széles (átl: 349 m; 82-460 m) folyóhátak fejlődnek, mint a magasodókkal szemben, ahol csupán átlagosan 65 m (56-87 m) szélesek alakultak ki. Tehát nemcsak az elforduló, de a megnyúló kanyarulatok esetében is szélesebb folyóhátak alakulnak ki az alacsonyodó övzátony-sorokkal szemben, de a különbséget felerösíti a kanyarulatfejlödés típusa.
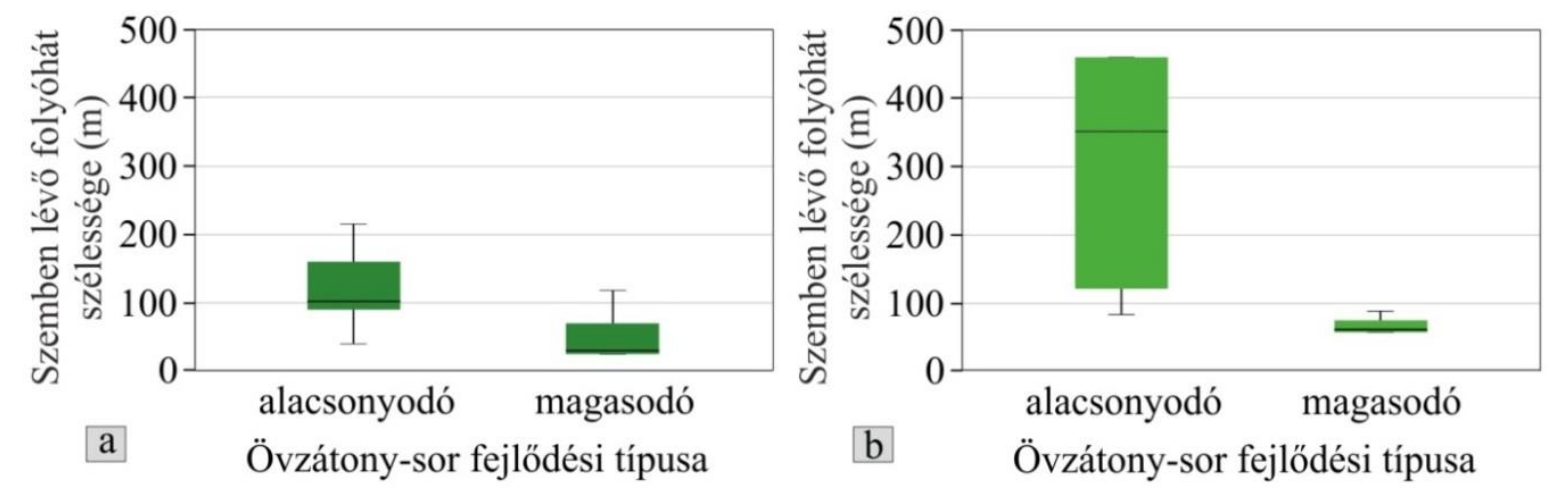

63. ábra. Az alacsonyodó és magasodó övzátony-sorokkal szemben fejlődő folyóhátak szélessége megnyúló (a) és elforduló (b) kanyarulatok esetén 
Véleményem szerint a két kanyarulatvándorlási típus közötti különbségek, tehát az, hogy az elforduló kanyarulatok külső ívén magasabb (0,7-1,2 m-rel) és szélesebb (229 m-rel) folyóhátak formálódnak, mint a megnyúló kanyarulatok mentén, a kanyarulatok görbületi sugarával áll szoros kapcsolatban. Az előző, folyóhátakat részletező 5.2 fejezetben megállapítottam, hogy minél kisebb egy kanyarulat görbületi sugara, a kialakuló folyóhát annál magasabb. Véleményem szerint az elforduló kanyarulatok mentén a kis görbületi sugár miatt a sodorvonal közelebb helyezkedik el a külső ívhez, ami azt jelenti, hogy árvizek idején a víz nagyobb erővel csapódik ki a hullámtérre, így nagyobb mennyiségü hordalék is jut oda ki.

Véleményem szerint a két övzátony-fejlödési típussal (alacsonyodó és magasodó) szemben épülő folyóhátak morfometriai különbségei a meder keresztszelvény méretével, illetve a hullámtér szélességével hozhatók kapcsolatba. Az alacsonyodó övzátony-sorokkal rendelkező szakaszokon a meder rendre nagyobb szelvényterülettel rendelkezik, mint a magasodó övzátony-sorokkal szemben (64. ábra). A nagyobb meder-szelvényterület és a kanyarulat külső ívén fejlődő folyóhát miatt itt lokálisan nagyobb a mederkitöltő vízhozam, így az árvíz a többi területhez képest később boríthatja el a folyóhátat, az áradás tetőzéshez közeli időszakában. A folyó által szállított hordalékhozam azonban ekkor a legnagyobb (Csépes et al. 2003), így a folyóhátak felszínén jóval nagyobb mennyiségü hordalék halmozódik fel, mint az áradások elején vagy végén. Ennek eredményeképpen az alacsonyodó övzátony-sorokkal szemben magas és széles folyóhátak alakulhatnak ki.
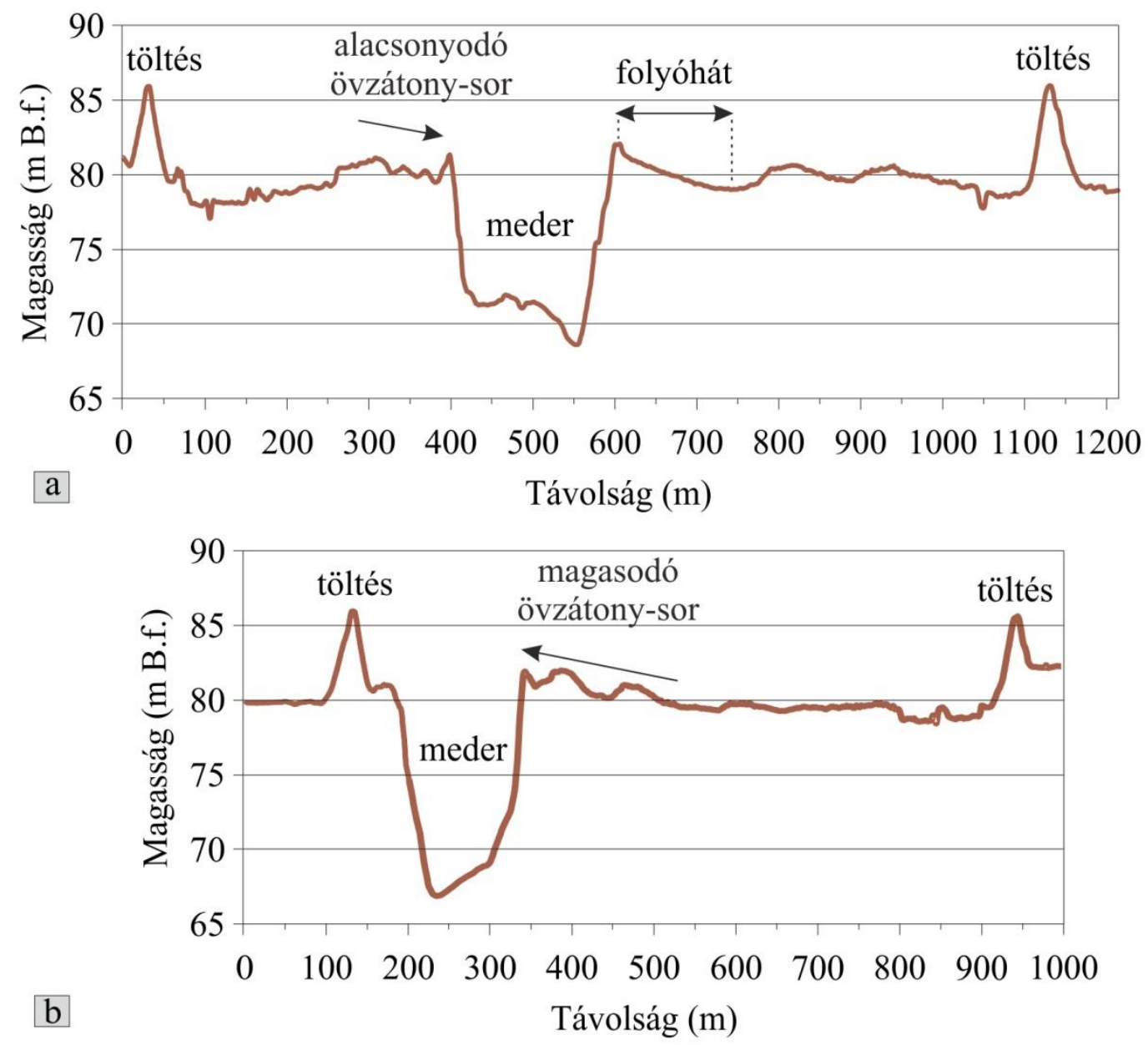

64. ábra. A mederszelvény mérete egy (a) alacsonyodó (221,5 fkm) és egy (b) magasodó $(214,7 \mathrm{fkm})$ övzátony-sorral szemben 
Ugyanakkor a magasodó övzátony-sorokkal szemben fejlődő alacsony és keskeny folyóhátak kialakulásának oka azonban nem köthető egyértelmüen a meder tulajdonságaihoz, hanem inkább a hullámtér szélességével áll kapcsolatban. Ezen típusok esetében mind az övzátonyok, mind a folyóhátak fejlődését befolyásolhatja, hogy a mederszelvény területe viszonylag kicsi, és rendre partbiztosítás akadályozza a laterális eróziót. Mivel ezek az övzátony-típusok elsősorban a nyugat felé vándorló kanyarulatok mentén jellemzőek, így az ilyen típusú övzátony-sorokkal szemben fejlődő folyóhátak a hullámtér jobb oldalán találhatóak. A hullámtér azonban ezen az oldalon a legszükebb, egyes szakaszokon a gát és a meder távolsága csupán 20 m, amely megmagyarázza az alacsony, keskeny és markáns lejtőjü folyóhátak kialakulását (65. ábra).

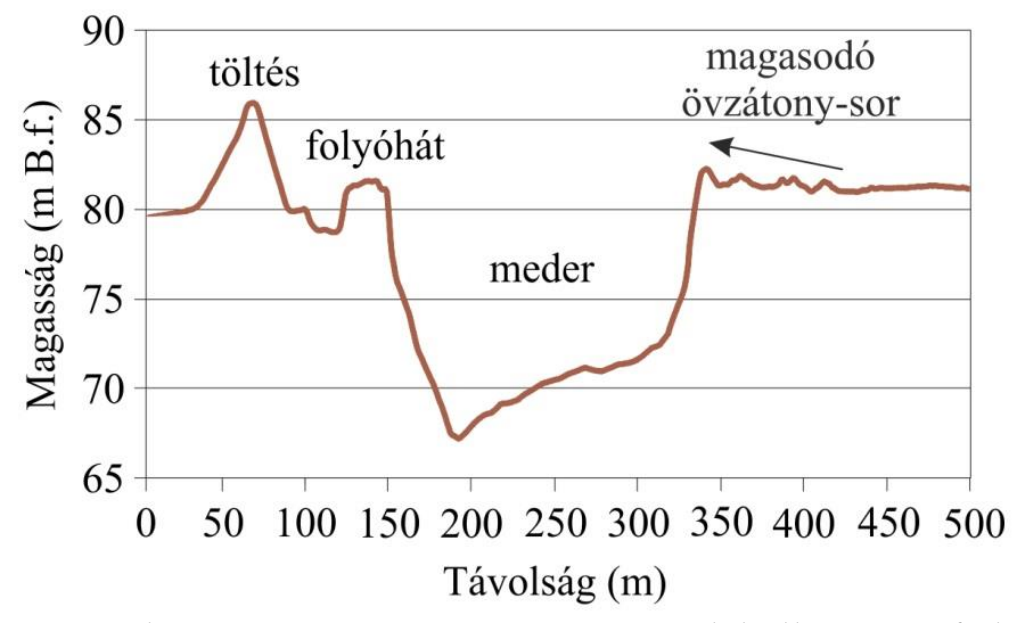

65. ábra. Egy magasodó övzátony-sorral szemben és szük hullámtéren fejlödő folyóhátról készült keresztmetszet

\subsubsection{Az övzátonyok és árvizek magassága közötti kapcsolat}

A kanyarulatok 39\%-ánál megfigyelhető az övzátony-sorokat alkotó tagok magasságának megemelkedése, illetve az, hogy a kanyarulatok 70\%-ánál a legfiatalabb övzátony jóval magasabb, mint a mögötte levő idősebb övzátonyok, amely jelentős hatással lehet a nagyvízi meder vízvezető-képességére, a mederből kilépő árhullám erejére és hordalékszállítására. Meg kell jegyeznem, hogy a hullámtérre az árvíz a partél alacsonyabb pontjain már korábban kiléphet, és így az ártér a természetes fokokon és mesterséges csatornákon keresztül alulról és hátulról elkezdhet vízzel „feltöltődni”, így az övzátonyok magasabb felszínei csak később kerülnek víz alá. A mindszenti vízmérce vízállás adatai alapján megvizsgáltam, hogy az övzátonyok magassági viszonyai milyen mértékben határozzák meg azt, hogy milyen magasságú és visszatérési idejű árvizek képesek elönteni a formákat, azaz milyen visszatérési idejü árvizek képesek hordalékot lerakni a felszínükön (66. ábra). Azért a mindszenti vízmérce adatait használtam fel, mert a mellékfolyók (Körösök és a Maros) visszaduzzasztó hatása kevésbé befolyásolja a vízállásokat, mint a szegedi és a csongrádi vízmércék esetében. A Mindszenttől felvízi és alvízi irányban elhelyezkedő kanyarulatok övzátonyait vizsgáltam meg, és ezek közül is csak azokat, ahol az övzátonysorok legutolsó tagjánál megfigyelhető a forma magasságának hirtelen megemelkedése.

A Mindszenttől felvízi irányban elhelyezkedö 17. sz. kanyarulat övzátony-sorát alkotó utolsó tag 1,2 méterrel magasabb $(2,3 \mathrm{~m})$, mint az utolsó előtti övzátony $(1,1 \mathrm{~m})$. Ha ez a magas aktív övzátony nem létezne, akkor ezen kanyarulat belső ívén már az $533 \mathrm{~cm}$-nél magasabb árvizek kiléphetnének a hullámtérre, és beboríthatnák az övzátony-sort. Ugyanakkor az utolsó magas övzátony-forma miatt jelenleg csak a legalább $656 \mathrm{~cm}$-es vagy ennél magasabb vízállások képesek elborítani az övzátony egészét. A 19. sz. kanyarulat esetében ez a különbség sokkal markánsabb, mivel a vizsgált kanyarulatok mentén itt 
tapasztalható a legnagyobb mértékü növekedés az utolsó övzátony magasságában. A kanyarulat mentén az utolsó forma jelenléte miatt csak a legalább $801 \mathrm{~cm}$-es vízállások borítják be az összes formát, míg a legfiatalabb övzátony nélkül már a $629 \mathrm{~cm}$ magas árvizek is közvetlenül elöntenék a környezö területeket. A 20. sz. kanyarulat esetében ez a különbség csupán $98 \mathrm{~cm}$, tehát az utolsó övzátonyt csak a legalább $724 \mathrm{~cm}$-es árvizek tudják elönteni, míg anélkül már a $626 \mathrm{~cm}$ magas vízállások is ki tudnának lépni a mederből. A 23. sz. kanyarulat esetében pedig az utolsó övzátony 1,4 m-rel magasabb, mint az azt megelőző, amelynek eredményeképpen ezen kanyarulat belső íve mentén ma már csak a legalább 671 cm magas tudnak kiönteni, míg e magas forma nélkül az 529 cm-es vízállások is elöntenék a hullámteret.

Tehát, ha a formák elöntését az árvizek visszatérési ideje felöl közelítjük meg, akkor megállapítható, hogy míg az utolsó előtti övzátony-tagokat az 1,2-1,8 évente visszatérö árvizek már beboríthatják, addig az utolsó, aktív övzátony magasságának megemelkedése miatt a vizsgált kanyarulatok mentén már csak a 2-4,8 évente visszatérő árvizek képesek csak az ártér egészét (övzátonyostul) elönteni. Ez azt is jelenti, hogy a korábbi övzátonyok gyakrabban kerülhettek elöntés alá, azaz felszínükön a hordalék-felhalmozódás korábban elindulhatott és tovább tarthatott. Ezzel szemben az utolsó övzátonyok - hasonlóan a folyóhátakhoz - a partélt magasítják, így ahelyett, hogy az árvíz fokozatosan és így kisebb munkavégző képességgel lépne ki a mederből, napjainkban csak a magasabb és pusztítóbb erejü árvizek képesek a teljes hullámteret elönteni. Az övzátonyok emelkedésével tehát romlik a hullámtér vízszállító képessége, így a mederben szállítódik az árvizek legnagyobb része, míg a hullámtér csupán a legmagasabb árvizek során vesz részt aktívan a víz levezetésében.

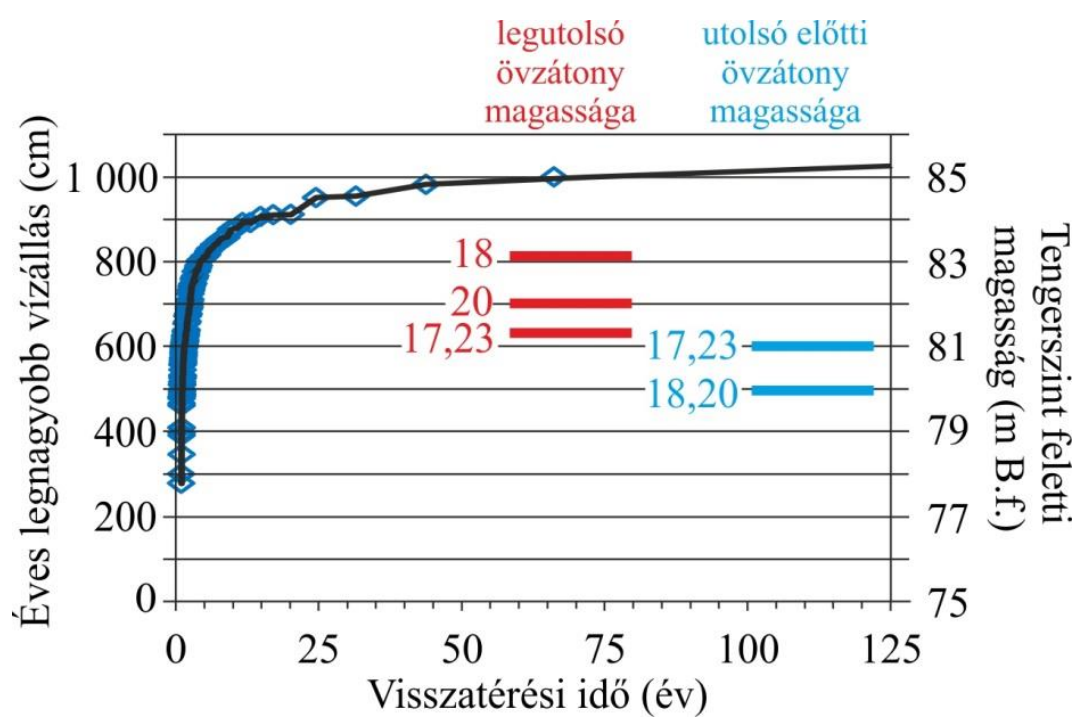

66. ábra. Az 1901 és 2016 között mért éves legnagyobb vizállások visszatérési ideje Mindszentnél a Gringorten-formula alapján számolva. Összehasonlitásképpen a vizmércétöl alvízi és felvizi irányban elhelyezkedö két-két kanyarulat övzátony-sorainak legutolsó és utolsó elötti tagjainak magasságát is feltüntettem, a számok pedig a kanyarulatok sorszámát jelölik 


\section{6. Összefoglalás}

Dolgozatomban az Alsó-Tisza Csongrád és a szerb országhatár közötti szakaszán a 19. századi szabályozások óta tartó hullámtéri feltöltődést és az azt befolyásoló helyi tényezőket vizsgáltam. Mivel a hordalék-felhalmozódás kitüntetett helyei és egyben a hullámtér leglátványosabb formái a folyóhátak és az övzátonyok, ezért kiemelten foglalkoztam ezen formák fejlődésével és a formálódásukat befolyásoló tényezők vizsgálatával is. Eredményeim alapján meghatároztam, hogy melyek azok a kitüntetett hullámtéri szakaszok, ahol fokozott hordalékfelhalmozódás figyelhető meg, így ezek azok a pontok, amelyek a legjelentősebb akadályt képezik az árvizek levonulásával szemben.

\subsection{A hullámtéri feltöltődés általános jellemzői és a folyamatot befolyásoló tényezők vizsgálatának eredményei}

Az Alsó-Tisza mentén kiszámítottam a 19. században zajlott árvízvédelmi töltések kiépítése óta felhalmozódott hordalék vastagságát és térfogatát, amelyet az aktív hullámtéri és a mentett ártéri területek magasságkülönbségéből határoztam meg digitális domborzatmodell alapján. Eredményeim szerint a hullámtéren átlagosan 1,2 m vastag hordalék halmozódott fel, amely 0,8 $\mathrm{cm} /$ év átlagos felhalmozódási ütemnek felel meg. Térfogatát tekintve pedig összesen 90 millió $\mathrm{m}^{3}$ hordalék akkumulálódott, tehát a szabályozások óta a Tisza közel 7 évnyi teljes lebegtetett hordalékmennyisége (ld. Bogárdi 1971) halmozódott fel. Ugyanezt a módszert alkalmazta a feltöltődés mértékének kiszámítására Gábris et al. (2002) a Felső-Tisza Tiszadob és Tiszaszederkény közötti, közel 10 km hosszú szakaszán, azonban ők közel feleakkora vastagságú felhalmozódást mértek (0,12-0,6 m; 0,1-0,5 mm/év), mint ami az Alsó-Tisza mentén jellemző. A feltöltődés általam meghatározott mértéke és üteme megfelel az Alsó-Tiszán Sándor és Kiss (2006b) által végzett korábbi méréseknek, hiszen a Mártélyi-holtág öblözetében $0,8 \mathrm{~cm} / \mathrm{é}^{\mathrm{v}}$ ütemü feltöltődéssel számoltak. Szintén hasonló eredményekre jutottak a Felsö-Tiszán Vass et al. (2009a), akik szerint a szabályozások óta legfeljebb 1,1 m vastag hordalék halmozódott fel, ugyanezen a szakaszon Szabót et al. (2008) pedig 0,8-1 cm/évben határozták meg a feltöltődés ütemét. Ugyanakkor a Közép-Tisza mentén is hasonló mértékü hordalék-felhalmozódással számolt Károlyi (1960), aki 1-1,5 m-re becsülte a feltöltődést, míg Sándor és Kiss (2006ab, 2007) szerint Szolnoknál 0,6-0,8 cm/év ütemmel töltődik a hullámtér.

Eredményeim azt mutatják, hogy az Alsó-Tisza mentén felhalmozódott hordaléknak sem a vastagsága, sem pedig térfogata nem egységes, hiszen az általam $1 \mathrm{~km}$-enként létrehozott területegységekben a felhalmozódás vastagsága 0,4-2,6 m között, míg térfogata 0,05-6,2 millió $\mathrm{m}^{3}$ között változik. Ez a különbözö, a hullámtéri feltöltődést helyben befolyásoló tényezők szerepére hívja fel a figyelmet, amelyek a hordalék-felhalmozódás térbeli mozaikos mintázatát eredményezik. Dolgozatomban a hullámtér szélességét, a hullámtéri növényborítást és a mellékfolyók (Hármas-Körös és Maros) hidrológiájának és az általuk szállított lebegtetett hordaléknak a hatását vizsgáltam meg, mint azon tényezőket, amelyek a feltöltődést a hullámtér teljes szélességében befolyásolják.

Az intenzív hullámtéri feltöltődés alapvető oka az árvízvédelmi töltések kiépítése, amelynek következtében az Alsó-Tisza eredeti 6-8 km széles ártere átlagosan 1 km-re szükült (Lászlóffy 1982). Így a folyó által szállított lebegtetett hordalék ezen a jóval szükebb hullámtéren kényszerül felhalmozódni (Károlyi 1960, Jakucs 1982, Nagy et al. 2001, Schweitzer 2001), így a hullámtér szélessége, ami adott ponton időben és térben is változatlan tényezö, közel 150 éve meghatározza a feltöltődés folyamatát. Eredményeim szerint a hullámtér-szélesség a felhalmozódott anyag térfogatát határozza meg egyértelműen $\left(\mathrm{R}^{2}=0,87\right)$, tehát szük hullámtéren kevesebb, míg szélesebb hullámtéri szakaszokon és a holtágak tág öblözeteiben nagyobb mennyiségü hordalékhalmozódik fel. A Felső-Tisza mentén Gábris et al. (2002) is ugyanezt a jelenséget figyelte meg. Ez összefüggésben állhat a folyó munkavégzö-képességével, ugyanis szük szakaszokon a felgyorsuló vízáramlás megakadályozza a nagyobb mennyiségü hordalék 
felhalmozódását, míg széles hullámtéren a víz lelassul, elősegítve az akkumulációt (Lecce 1997). Egyes kutatások szerint (Magilligan 1985, Lecce 1997) a hullámtér szélessége 52-57\%-ban határozza meg a felhalmozódó hordalék mennyiségét, eredményeim szerint azonban ez az arány az Alsó-Tisza mentén jóval jelentősebb mértékü, amelyre a hullámtér-szélesség és a hordalék térfogata közötti erős korreláció enged következtetni. A felhalmozódott hordalék vastagsága és a hullámtér szélessége között egyértelmü kapcsolatot nem sikerült kimutatnom, amely más helyi tényezők fontosságát is jelzi, illetve azt, hogy az adott helyen kialakuló, mederélhez kötődő ártéri formák (folyóhátak és övzátonyok) is alapvetően befolyásolhatják a feltöltődés vastagságát.

Eredményeim szerint az Alsó-Tiszába ömlö mellékfolyók eltérö hatást gyakorolnak a Tisza menti hullámtér feltöltődésére, illetve a Hármas-Körös esetében, legfeljebb $5 \mathrm{~km}$, míg a Maros esetében legfeljebb $8 \mathrm{~km}$ hosszú szakaszt érintenek, hiszen itt jelentkezik a Tisza eséséhez, hordalékhozamához és fajlagos munkavégző-képességéhez képest a legnagyobb hordaléktöménység-változás. Mivel a Hármas-Körös és a Maros esésviszonyai, illetve az általuk szállított fenék- és lebegtetett hordalék-mennyisége is különböző, eltérő hatást gyakorolnak a Tisza hullámterének feltöltődésére. A Hármas-Körös torkolata alatt $0,2-1,1 \mathrm{~m}$-rel vékonyabb $(0,4-$ $1,1 \mathrm{~m})$, térfogatát tekintve pedig feleannyi $\left(0,25-0,34\right.$ millió $\left.\mathrm{m}^{3}\right)$ hordalék akkumulálódott, mint a torkolattól felvízi irányban $\left(0,6-2,2 \mathrm{~m} ; 0,18-0,86 \mathrm{millió}^{3} \mathrm{~m}^{3}\right)$. Véleményem szerint ennek oka, hogy a Körösökön épített duzzasztók a hordalék nagy részét felfogják, hiszen a folyó mindössze 0,4 millió $\mathrm{m}^{3}$ lebegetett hordalékot szállít évente (Bogárdi 1971). A két folyó vízhozamának egyesülésével a Körösök vízének viszonylagos hordalékszegénysége párosul a két folyó megnövekedett vízhozamával, ami miatt a torkolat alatt megnő a Tisza munkavégző képessége, ami a hordalékszállítás felé tolhatja el a szakasz hordalékegyensúlyát az akkumuláció irányából. Ez a hatás a torkolattól alvízi irányban $5 \mathrm{~km}$-es távolságig érvényesül, ahonnan a Tisza hullámterének feltöltődése ismét intenzívebbé válik. Ezt a folyóhátak szemcseösszetétele is alátámasztja, hiszen a torkolat alatti $5 \mathrm{~km}$ hosszú szakaszon belül a folyóhátak felső $5-10 \mathrm{~cm}$ mély rétegében nem fordult elő homokos hordalék, csupán az árvizek apadó ágában a kis vízsebességü vízből kiülepedő iszap és agyag.

A Maros esetében a torkolat alatti szakaszon átlagosan 0,6 m-rel vastagabb felhalmozódás figyelhető meg, mint felette (torkolat felett átlagosan 1,0 m (0,5-1,9 m), 0,26 millió $\mathrm{m}^{3}$; torkolat alatt átlagosan 1,6 m (1-2,1 m), 0,13 millió $\left.\mathrm{m}^{3}\right)$, azaz itt - a Körösökkel ellentétben - nem figyelhető meg az akkumuláció csökkenése. Ugyanakkor, míg a Körös-torkolattól 5 km-re kezdődik a hullámtér fokozottabb feltöltődése, addig a Maros esetében itt a torkolattól kissé távolabb (4 km), Szegedtől közvetlenül délre indul meg a hordalék intenzívebb felhalmozódása. Véleményem szerint a Maros eltérö hatása a Tisza hullámterének feltöltődésére összefüggésbe hozható a Szeged környéki rendkívül szük hullámtérrel (átl. $470 \mathrm{~m})$, és nagy esése $(7-9 \mathrm{~cm} / \mathrm{km}$; Kiss et al. 2011) miatt megnövekedő fajlagos munkavégző képességével. Ezen tényezők miatt a hordalék felhalmozódása helyett annak elszállítása jellemző a torkolattól számított 4 km-en belül annak ellenére, hogy a Maros nagy mennyiségü hordalékkal (4,6 millió m³/év; Bogárdi 1971) járul hozzá a Tisza hordalékhozamához. A Szeged alatti szakaszon, a torkolattól 4 km-re azonban a hullámtér kitágul (átlagosan 750 m-re), így a vízáramlás kissé lelassul és megindulhat a hordalék intenzívebb akkumulációja, amihez hozzájárul a Maros nagy hordalékhozama is.

A hullámtér feltöltődésére kiemelt hatása van a hullámtér növényzete és a növényzet sürüsége. Ebben jelentős szerepe van az árvíz-mentesítési munkálatok következtében megváltozott felszínborításnak, a 20. század második felében intenzívebbé váló erdőgazdálkodásnak, illetve az ezzel párhuzamosan intenzív terjedésnek induló nem őshonos, invazív növényfajoknak is. A 18. század vége óta az Alsó-Tisza felszínborítása és vele együtt a hullámtéri felszín növényzeti érdessége jelentős változásokon ment keresztül. Az árvízvédelmi töltések kiépítése elött a jelenlegi hullámtér területének 83\%-a állandó vagy időszakos vízborítás alatt állt, míg a töltések kiépítése után arányuk hirtelen lecsökkent, és a mocsaras területeket kezdetben fokozatosan felváltották a rétek és legelők, amelyek később beerdősülésnek indultak. $\mathrm{Az}$ 1800-as évek végén a rétek és legelök a mintaterület 76\%-át alkották, amelyek felén ekkor már megjelent a fásszárú növényzet. Ezzel párhuzamosan a felszín növényzeti érdessége a 
kétszeresére nőtt (1784: $\mathrm{n}=0,02 ; 1881: \mathrm{n}=0,048)$. Az 1900-as évek végén azonban az erdőtelepítések hatására a mintaterület legnagyobb részét (61\%) már erdők borították, amely a rétek és legelők területének zsugorodásához vezetett. Ez a következő évtizedekben tovább folytatódott, így 2017-re az erdők kiterjedése 73\%-ra nőtt, a rétek és legelők aránya pedig 11\%-ra csökkent. Ezt a változást követte a növényzeti érdesség is, hiszen értéke a 2017. évi légifelvétel alapján meghatározott felszínborítás szerint $n=0,09$ volt. Ezeket a növényzeti érdesség értékeket a szakirodalomban (Chow 1959) megtalálható érdességi értékek alapján számítottam ki, azonban ezek az adatok nem foglalják magukba a különböző invazív fajok hatását. Az Alsó-Tisza mentén a gyalogakác (Amorpha fruticosa) az egyik legnagyobb problémát okozó invazív faj, amelynek jelenléte tovább növeli a hullámtér növényzeti érdességét. Terepi méréseim szerint a gyalogakác az összes felszínborítási kategóriában jelen van, és csupán a mintaterület $13 \%$-a nem fertőzött. A különböző felszínborítási kategóriák gyalogakáccal való fertőzöttsége eltér, hiszen a természetközeli ártéri erdőkben átlagosan 3\%-kal, az ültetett nyárerdőkben 23\%-kal, míg a parlagon hagyott réteken, legelökön és szántóföldeken átlagosan 76\%-kal növeli a hullámtéri növényzet sürüségét, egyes területeken azonban a gyalogakác aránya a $100 \%$-ot is elérheti. A gyalogakác jelenléte miatt a felszín növényzeti érdessége az irodalmi adatok alapján meghatározottnál még magasabb, eredményeim szerint ezen invazív növényfajt is figyelembe véve a felszín érdessége 2017 -ben $n=0,11$ volt, tehát a 18 . század vége óta a növényzet okozta érdesség közel ötszörösére növekedett. Mindszent térségében végzett kutatásai alapján Sándor (2011) is hasonló arányú érdesség-növekedést mutatott ki.

Sajnálatos módon kutatásom időszakában (2016-2019) nem fordult elő a partéleken átbukó magasságú árvíz, így a különböző növényborítással rendelkező területeken nem tudtam vizsgálni a frissen lerakódott hordalék vastagságát és mintázatát, illetve vízsebesség-méréseket sem tudtam végezni a hullámtéren, amelyek alapján részletesen vizsgálható lett volna a növényzet hordalékfelhalmozódásra gyakorolt hatása. A domborzatmodell alapján meghatározott feltöltődés vastagsága nem mutat egyértelmü kapcsolatot a felszín növényzeti érdességével. Ennek legföbb oka véleményem szerint az, hogy míg a nagyon sürü növényzet legfeljebb a 20. század közepétől fejt ki jelentősebb hatást a hordalék-felhalmozódásra, addig a feltöltődést az általam alkalmazott módszerrel jóval hosszabb, a 19. századi gátépítések óta eltelt időszakra vonatkozóan határoztam meg. A feltöltődés vastagsága és a növényzeti érdesség adatai alapján azonban sikerült meghatároznom, hogy az $n=0,08$ növényzeti érdesség egy küszöbértéket jelent a hordalékfelhalmozódás szempontjából. Eszerint a part menti növényzet sürüsödésével a hullámtérre kilépő víz sebessége egyre nagyobb mértékben mérséklődik, tehát a part menti növényzet egyre nagyobb mennyiségü hordalék felhalmozódását eredményezi, mindaddig, amíg a növényzeti érdesség el nem éri az $n=0,08$ értéket. Az érdesség további növekedésével $(n>0,08)$ azonban csökkenni kezd a feltöltődés vastagsága. Ez azzal magyarázható, hogy terepi tapasztalataim szerint a partokon helyenként áthatolhatatlanul sürü növényzet nö, ami árvizekkor szüröként vagy szivacsként viselkedhet. Azaz nagy valószínűséggel a vízáramlás sebessége olyannyira lecsökkenhet már a partélnél, hogy a hordalék nem jut el a parttól távolabbi területek felé. Azonban ennek bizonyításához árvízi vízsebesség- és hordalékmérések lennének szükségesek, de a kutatásom alatt a partéleket elöntő árhullám nem alakult ki az Alsó-Tiszán.

Ugyanakkor a felszín növényzeti érdessége és a feltöltődés közötti kapcsolatot más kutatások is kimutatták. Az Alsó-Tisza mindszenti szakaszán végzett kutatásai alapján Kiss (2014) szintén kimutatott egy küszöbértéket a felszín növényzeti érdességében, bár ezt jóval magasabb, $\mathrm{n}=0,2$ érdességben határozta meg néhány kvadráton a növényzet felmérése alapján. Szintén a folyó mindszenti szakaszán Sándor és Kiss (2006b) a hordalék-felhalmozódás ütemének megkétszereződését mutatták ki az 1970-es éveket követően (0,4-0,7 cm/évröl 1,2-1,5 cm/évre). Ezt Sándor és Kiss $(2007,2008)$ a felszín növényzeti érdességének növekedésével magyaráztak, amelyben vizsgálataik szerint jelentős szerepet játszik a gyalogakác intenzív terjedése, illetve az erdőművelés miatt megjelenő tuskógátak. Steiger et al. (2001) a hordalék-felhalmozódás sebességének megötszöröződését figyelték meg a part menti növényzet sűrúbbé válása következtében, illetve kimutatták (Steiger és Gurnell 2003), hogy különböző felszínborítási 
kategóriákban eltérő az akkumuláció sebessége, ugyanis sürü ártéri erdőkben négyszer olyan gyors akkumulációt mértek, mint a ritkább, gondozott aljnövényzetü ültetett erdőkben.

A 19. századi gátépítés óta tartó feltöltődés összességében az Alsó-Tisza menti hullámtér vízszállító-képességének csökkenését eredményezte, amelynek mértéke eredményeim szerint átlagosan 22,6\%. A csökkenés mértéke azonban területegységenként eltérő, 0-52\% között változik. A legnagyobb vízszállító-képességcsökkenéssel jellemezhető területek elsősorban a szük hullámtéri szakaszokon fordulnak elő Csongrád, Mindszent, Algyő és Szeged környezetében. Ezen szakaszokon a hullámtér vízszállító képességének csökkenése meghaladja a 40\%-ot, tehát napjainkban az árvizek levonulására közel feleakkora térfogat áll rendelkezésre, mint az árvízvédelmi töltések kiépítését követően. Véleményem szerint ezeken a legrosszabb vízszállítóképességgel rendelkező szakaszokon kellene javítani a hullámtéren az áramlási viszonyokat. Ez megvalósítható lenne például a mederrel párhuzamosan elhelyezkedő és kis növényzeti érdességü vízvezető sávok kialakításával, hiszen a felgyorsult vízáramlás miatt megnövő fajlagos munkavégző-képesség hatására kevesebb hordalék tudna akkumulálódni a hullámtéren. Az invazív gyalogakác miatt jelentősen megnőtt növényzeti érdesség kedvez a hordalék felhalmozódásának. A gyalogakác irtásával, az ültetett erdők megfelelő és rendszeres gondozásával, illetve az eredeti felszínborítási kategóriák (rétek, legelők, szántók) visszaállításával és legeltetésével csökkenthető lenne a felszín növényzeti érdessége, ezáltal mérséklődne a hordalék akkumulációja is. HEC-RAS modell eredményei alapján a növényzet érdességének hosszabb hullámtéri szakaszon történő csökkentésével az árvizek tetőző vízállása 22 cm-rel is csökkenthető lenne (Kiss et al. 2019c). Továbbá úgy gondolom, hogy az áramlási viszonyok javulását eredményezhetné a hullámtéren belüli mesterséges akadályok (illegális hordalék-lerakók, tuskógátak) felszámolása is. A nagyon rossz vízszállító-képességü (gyakorlatilag hordalékdugóként funkcionáló) szakaszok árvizek idején a hullámtér kritikus pontjait jelentik, így ezeken a szakaszokon - ártérkezelés hiányában - célszerü lenne a töltésmagasságokat átgondolni, esetleg azok magasítását célul kitüzni.

\subsection{A folyóhátak vizsgálatának eredményei}

A folyóhátak az árterek feltöltődésének leglátványosabb formái. Vizsgálatukat kiemeltnek tekintettem a hullámtér hosszú távú feltöltődése szempontjából, ugyanis ezek a kanyarulatok külső ívén fejlődő és vertikálisan épülő formák alapvetően meghatározzák a hullámtér távolabbi részei felé kijutó víz-és hordalékmennyiséget (Happ et al. 1940, Brierley et al. 1997, Nagy et al. 2001), így folyamatos magasodásuk révén a hullámtér vízszállító-képességét is befolyásolják (Kozák és Rátky 1999, Nagy et al. 2001).

A folyóhátakat az Alsó-Tisza 35 kanyarulata mentén vizsgáltam, két csoportra osztva őket, aszerint hogy ál- és fejletlen, vagy fejlett és érett kanyarulatok mentén fordulnak-e elö. A folyóhátak tulajdonságait (magasságát,szélességét és épülésük ütemét) és az ezeket befolyásoló tényezők hatását ezen két kanyarulati csoporton belül vizsgáltam. A kettéosztást az indokolta, hogy míg az ál-és fejletlen kanyarulatok rendszerint nagy $\left(\mathrm{R}_{\mathrm{c}}>1000 \mathrm{~m}\right)$ görbületi sugárral rendelkeznek, addig a fejlett és érett kanyarulatok élesek $\left(\mathrm{R}_{\mathrm{c}}<1000 \mathrm{~m}\right)$. A görbületi sugár pedig befolyásolja egyrészt azt, hogy a sodorvonal milyen közel húzódik a partélhez, másrészt azt, hogy milyen sebességgel áramlik az árvíz a forma felett, tehát a kanyarulatok különböző tulajdonságai eltérő mértékben befolyásolják a folyóhát-épülés folyamatát.

Az Alsó-Tisza mentén a folyóhátak nagyon változatos morfológiai tulajdonságokkal rendelkeznek, mind magasságukat (2,6-4,9 m), mind szélességüket tekintve $(25-550 \mathrm{~m})$, de épülésük üteme is jelentősen eltér (15-122 mm/év). A formák tulajdonságainak ezen változatossága a feltöltődést befolyásoló tényezők különböző szerepére hívja fel a figyelmet. Eredményeim szerint a folyóhátak méretét (magasságát és szélességét) a kanyarulatok görbületi sugara és a hullámtér szélessége, míg a formák épülésének ütemét pedig a forma kora és a sodorvonal külső partéltől való távolsága határozza meg leginkább. Az egyes paraméterek közötti 
kapcsolatok azonban eltérnek a különböző fejlettségü (ál-és fejletlen, illetve fejlett és érett) kanyarulatok mentén.

A görbületi sugár és a hullámtér szélességének hatását egyszerre vizsgáltam. Míg a görbületi sugár a partél sávjában befolyásolja a mederből kilépő víz sebességét és munkavégző képességét, addig a hullámtér-szélesség befolyásolja a hullámtér távolabbi területein az árvíz áramlási viszonyait, és ezáltal a hordalék mozgását. Más kutatások is kiemelik az ártér/hullámtér szélességét, mint a folyóhátak morfológiáját alapvetően befolyásoló tényezőt (Brierley et al. 1997, Thonon et al. 2007, Klasz et al. 2014).

Az ál-és fejletlen kanyarulatok mentén a görbületi sugár folyóhátak magasságára gyakorolt hatása gyengébb, amely kapcsolatban áll a nagy görbületi sugárból adódó kisebb centrifugális erővel, illetve az ezen kanyarulatok mentén jellemző szük hullámtéri szakaszokkal, amely felülírja a görbületi sugár hatásának közvetlen érvényesülését. Ezen kanyarulatok mentén ugyanis a hullámtér mindenhol 750 m-nél szükebb, továbbá a kanyarulatok 60\%-a esetén szükebb, mint 200 m. Így a formák magasságát elsősorban a hullámtér szélessége határozza meg. A folyóhátak szélességét ezzel szemben szinte kizárólag a hullámtér-szélesség befolyásolja. A formák magassága és szélessége közötti kapcsolat is mutatja a hullámtér szélességének dominánsabb hatását, hiszen ezen kanyarulati csoporton belül a magas folyóhátak elsősorban keskenyek.

A fejlett és érett kanyarulatok mentén a görbületi sugár már erőteljesen befolyásolja a folyóhátak magasságát, amely elsősorban a széles hullámtéri szakaszokon elhelyezkedő kanyarulatoknál tapasztalható. Mivel ezen kanyarulatok többsége kis görbületi sugárral rendelkezik, így a széles hullámtér miatt elegendö hely áll rendelkezésre ahhoz, hogy a nagy centrifugális erő által nagy energiával a hullámtérre szállított hordalék egy magasabb folyóhát kialakulását eredményezze, illetve így lehetőség van a formák szélesedésére is. A kanyarulatok görbületi sugara és a folyóhátak szélessége között Hudson és Heitmuller (2003) is hasonló kapcsolatot figyelt meg, tehát kis görbületi sugár esetén a hordalék nagyobb távolságra képes eljutni az ártéren, amely széles folyóhátak kialakulását eredményezi. Eredményeim azt mutatják, hogy a fejlett és érett kanyarulatok másik felénél azonban a hullámtér szük, így ezeken a szakaszokon a hullámtér-szélesség felülírja a görbületi sugár hatását, amely magas és keskeny folyóhátak kialakulását eredményezi.

Dolgozatomban megvizsgáltam a partbiztosítások folyóhátak magasságára gyakorolt hatását is, ugyanis az Alsó-Tisza hosszának 51\%-a partbiztosított, ami jelentősen módosítja a külső ív eróziós folyamatit, amely a folyóhátak épülését alapvetően meghatározza (Hickin és Nanson 1975). Eredményeim szerint a kőrakatokkal biztosított szakaszok mentén 20-30 cm-rel magasabb formák épültek mindkét kanyarulati csoport mentén. Bár ez a különbség egyértelmünek tekinthető, de mértéke a mérés hibahatárán belül esik. Véleményem szerint azonban ténylegesen állhat fenn különbség a partbiztosított és a kőrakatoktól mentes szakaszok folyóhát-magasságai között, hiszen egy, a Maroson végzett kutatás (Kiss et al. 2018b) szerint a partbiztosított szakaszokon 24-36\%-kal magasabb folyóhátak fejlődtek, mint a szabadon fejlődő kanyarulatok mentén. Egy másik, a Duna osztrák szakaszán végzett kutatás (Klasz et al. 2014) is hasonló különbségeket írt le.

A folyóhátak épülésének üteme mindkét kanyarulati csoport esetében szoros kapcsolatot mutat a formák korával, tehát azzal, hogy milyen hosszú ideje történik a felszínükön hordalékfelhalmozódás. Eredményeim szerint a legidősebb ( $>180$ év) formák átlagosan 21-22 mm/év ütemben épülnek, míg a legfiatalabbak (legfeljebb 40 éves) formák felszínén jóval gyorsabban, átlagosan 83-115 mm/év ütemmel zajlik az akkumuláció. Mindez a hordalék-felhalmozódás ütemének gyorsulását mutatja az utóbbi évtizedekben, amit tükröz a folyóhátak anyagának fokozatos durvulása is. A gyorsabb feltöltődés legföbb oka véleményem szerint az egyre sürübbé váló part menti növényzet, hiszen a 18. század vége óta a felszín növényzeti érdessége az ötszörösére növekedett, amelyben nagy szerepet játszik a 20. század közepe óta intenzív terjedésnek indult gyalogakác. Ez kombinálódik az egyre szükebb mederből egyre nagyobb munkavégző képességgel kilépő árhullám (Kiss 2014) fokozott hordalékszállító képességével, ami a folyóhátak part menti sávjának erőteljes feltöltődéséhez vezet. 
A folyóhátak felszínén a hordalék-felhalmozódás üteme azonban kis mértékben mérséklődhet a kanyarulat külső ívéhez közel helyezkedő sodorvonal miatt. Úgy vélem, ugyanis, hogy árvizekkor a sodorvonal közelsége a víz nagyobb munkavégző-képességét eredményezi, amely megakadályozza, hogy nagyobb mennyiségü hordalék akkumulálódjon közvetlenül a part mentén, illetve a folyóhátak anyaga erodálódhat is, amely a formák átlagos épülési sebességének csökkenését eredményezi. Ezen feltételezésemet Uddin és Rahman (2012) vizsgálatai is alátámasztják.

Mivel a folyóhátak a hullámtér legmagasabb formái, amelyek a partél mentén fejlődnek, ezért jelentős hatást gyakorolnak a hullámtér vízvezetö képességére, hiszen a kanyarulatok külső ívén meghatározzák, hogy milyen magasságú árvíz képes kilépni adott ponton a hullámtérre. Dolgozatomban megvizsgáltam, hogy a jelenlegi formák felszínét milyen magas árvizek képesek elönteni és építeni. Eredményeim szerint a formákat a legalább 758-842 cm magas árhullámok képesek csak beborítani, amely a 3,2-4,6 évente visszatérö árvizeket jelenti. A folyóhátak medertől távolabbi felszíne azonban alacsonyabb vízállások esetén is magasodhat, hiszen kisebb árhullámok idején a fokokon keresztül az alacsonyabb területek vízborítás alá kerülnek, de ekkor a folyóhátak medertől távolabbi peremén legföképpen kisebb szemcseméretü, lebegtetett hordalék rakódhat le és jóval kisebb vastagságban (Sándor 2011).

A folyóhátak szemcseösszetételének vizsgálata rávilágított az Alsó-Tisza mentén jellemző hidrológiai viszonyok megváltozására. A formák anyagát a felszín felé haladva egyre nagyobb arányban (> 50\%) alkotja homok, amely az egyre nagyobb energiájú árvizek gyakoriságának növekedését jelzi. Ennek hatására pedig egyre nagyobb mennyiségü homok képes a hullámtér szük parti sávjában felhalmozódni.

\subsection{Az övzátonyok vizsgálatának eredményei}

Az övzátonyok a folyóhátakhoz hasonlóan az árterek legjellegzetesebb formái és a hordalék oldalirányú felhalmozódásnak kitüntetett helyei (Wolman és Leopold 1957), ezért a fejlődésüket befolyásoló bármely tényező megváltozását formálódásuk is tükrözi. Mivel az Alsó-Tiszát különböző típusú, de igen intenzív emberi hatások érték az elmúlt évszázadokban, ezek hatottak az övzátonyok morfológiájára is, és a kezdetben természetes körülmények között ható tényezők hatását az antropogén hatások egyre inkább felülírják. Az övzátonyok fejlődését és alaktani tulajdonságait meghatározó tényezők hatása közötti kapcsolatrendszer nem minden esetben teljesen egyértelmü. Ennek oka, hogy minden kanyarulat eltérő görbületi sugárral rendelkezik, különböző kanyarulat-fejlödési típusba tartoznak, a meder szélessége változó, és a partok kötöttsége is helyröl-helyre változik. Az övzátony-épülés folyamatát továbbá befolyásolja az is, hogy adott kanyarulat alatt vagy felett történt-e kanyarulat-átvágás, ráadásul a külső íven található partbiztosításokat is különböző időpontokban építették, tehát azok eltérő időben kezdték az adott kanyarulat fejlődését módosítani.

Az egyes kanyarulatokban kialakult övzátony-sorokat alkotó tagok magasságának meder irányában történő változása alapján három övzátony-fejlödési típust különböztettem meg: a meder felé haladva alacsonyodó, magasodó és változatlan magasságú övzátony-sorokat. Véleményem szerint ezen típusok összefüggnek a meder morfológiában, a kanyarulatvándorlás sebességében, és/vagy a fenék- és lebegtetett hordalékhozamban bekövetkezett változásokkal. Eredményeim alapján úgy vélem, hogy az övzátony-tagok magasságának csökkenése utalhat a meder helyi bevágódására, a kanyarulatvándorlás sebességének növekedésére, illetve az övzátonyt felépítő fenék- és lebegtetett hordalék hozamának csökkenésére is. Ezzel szemben az övzátony-tagok magasságának növekedése utalhat a kanyarulatvándorlás lassuló ütemére, illetve adott ponton az övzátonyt felépítő fenék- és lebegtetett hordalék hozamának növekedésére is. Mivel az alacsonyodó, magasodó és változatlan magasságú övzátony-sorok egymás szomszédságában fordulnak elö, a hordalékhozam általános változása az Alsó-Tiszán nem lehet kialakulásuk oka, hiszen az a formák magasságának változását egységesen eredményezné. Tehát az övzátonyfejlődési típusok létrejötte helyi befolyásoló tényezők szerepére hívja fel a figyelmet. Például az 
övzátony-fejlödési típusok létrejöttére és térbeli elhelyezkedésére jelentős hatással van a mederanyag kötöttsége, illetve az, hogy a nyugati oldalon az árvízvédelmi töltés jóval közelebb fut a mederhez, mint a folyó keleti oldalán, így a partbiztosítások is elsősorban a nyugati oldalon helyezkednek el. Ennek eredményeképpen az alacsonyodó övzátonyok-sorok többsége a hullámtér baloldalán, míg a magasodó övzátonyok a hullámtér jobb oldalán találhatók.

A kanyarulatok fejlödési (vándorlási) típusa jelentős hatással van az övzátonyok fejlődésére és morfológiai tulajdonságaira emberi beavatkozásoktól mentes környezetben (Hickin 1974, Hickin és Nanson 1975, Nanson és Hickin 1983, Russell et al. 2018, Strick et al. 2018), de pontos hatásával csupán Strick et al. (2018) foglalkoztak részletesen. Ezért fontosnak tartottam ezen befolyásoló tényező vizsgálatát, ráadásul az Alsó-Tiszán a kanyarulatok és az övzátonyok fejlődését is módosíthatták a mederrendezési munkák. Az Alsó-Tisza mentén összesen három kanyarulatfejlödési típust különböztettem meg. A kanyarulatok többségének $(70 \%)$ vándorlása megnyúló jellegü, 27\%-át az elforduló mozgás jellemzi, míg az áthelyeződő típusba csupán egy kanyarulat tartozik (22. számú Ányási-kanyarulat). A különböző típusok jelenléte összefüggésben áll egyrészt a meder-szabályozási munkálatokkal, mivel a megnyúló kanyarulatok elsősorban a mederrendezés során kiegyenesített szakaszokon találhatók. Másrészt jelentős szerepe van a felszínt felépítö üledékek (mederanyag) kötöttségének is, amely az Alsó-Tisza mentén igen változatos (Hernesz 2015). Ennek eredményeképpen a kanyarulatok külső ívének egyes szakaszai intenzívebben pusztulnak, amely a kanyarulat tengelyének elfordulását eredményezi. Véleményem szerint az üledékek változatos kötöttsége miatt a jóval fiatalabb megnyúló kanyarulatok fejlődésük előrehaladtával elforduló jellegüvé válhatnak.

A különböző típusok övzátony-morfológiára gyakorolt hatásával a hazai szakirodalom egyáltalán nem, a külföldi kutatások pedig alig foglalkoztak. Strick et al. (2018) szerint az elforduló kanyarulatok mentén magasabb és szélesebb övzátonyok alakulnak ki, mint a többi kanyarulatvándorlási típus esetén. Eredményeim szerint azonban kizárólag a fejlődés típusa nem eredményezi a formák magasabb és szélesebb voltát, hiszen a megnyúló és elforduló kanyarulatok mentén is hasonló a formák átlagos magassága (2,3 m illetve $2 \mathrm{~m}$ ) és szélessége is ( $33 \mathrm{~m}$ és $27 \mathrm{~m}$ ). A típusok közötti különbségek azonban kapcsolatban állnak a kanyarulatok görbületi sugarával is, viszont az övzátonyok alaktani tulajdonságai és a görbületi sugár között kapcsolatot csak az elforduló típusú kanyarulat esetén találtam. Ennek oka, hogy az elforduló kanyarulatok többsége kis görbületi sugárral rendelkezik $\left(\mathrm{R}_{\mathrm{c}}<750 \mathrm{~m}\right)$, így a sodorvonal közelebb helyezkedik el a külsö ívhez, ezért a kanyarulat belső ívén gyorsabb a hordalék felhalmozódása. Hasonló jelenséget figyelt meg Nanson és Hickin (1983) a Beatton folyón. A belső íven a nagy mennyiségü hordalék lerakódását tovább fokozza a kanyarulat fejlődési típusa, mivel az elforduló jelleg miatt az övzátonyok saját magukra fordulnak vissza, amely növeli a formák magasságát és szélességét (Strick et al. 2018). Ezt bizonyítják az övzátonyok magassági és szélességi viszonyai is, hiszen a legkisebb görbület sugarú $\left(R_{c}=150-230 \mathrm{~m}\right)$ kanyarulatok mentén 4-4,4 magas és $31 \mathrm{~m}$ széles, míg az elforduló típusba tartozó legnagyobb görbületi sugárral $\left(\mathrm{R}_{\mathrm{c}}=1380 \mathrm{~m}\right)$ rendelkező kanyarulat belső ívén 2,8 m magas és 11,5 m széles övzátony formálódott. Tehát ebben az esetben igaz Strick et al. (2018) megállapítása, miszerint az elforduló kanyarulatok mentén magasabb és szélesebb övzátonyok formálódnak, mint a megnyúló típusú esetén, de ez nem kizárólag a kanyarulatvándorlási típus függvénye, hanem eredményeim szerint jelentős szerepe van a kanyarulatok görbületi sugarának is.

Az övzátonyok épülését alapvetően a külső íven zajló medererózió és az ezzel együtt járó kanyarulatvándorlás szabályozza, amelyet számos kutatás is kiemel (Hickin 1974, Hickin és Nanson 1975, Strick et al. 2018), így az ezekben bekövetkező változások befolyásolják a formák épülését is. Az Alsó-Tisza mentén a 19. századi kanyarulat-átvágások, majd a 20. század során a partbiztosítások kiépítése alapvetően módosította a kanyarulatok vándorlásának ütemét, ezáltal az övzátonyok fejlődését is. A kanyarulat-átvágások hatására nőtt az esés, így a meder bevágódott (Kiss et al. 2008). A meder mélyülését az övzátony-sorokat alkotó tagok magasságának folyamatos csökkenése jelezte, ezt bizonyítja az egyes övzátony-sorok tagjainak meder irányában csökkenő magassága is. A szabályozásokat követően a nagyobb esés okozta munkavégzö- 
képességnövekedés átmenetileg a meder kiszélesedését is eredményezte, hiszen míg a meder átlagszélessége az 1861. évi felmérésen 175 m volt, addig 1890-ig átlagosan 192 m-re szélesedett. A 20. század során azonban a meder folyamatos szükülése tapasztalható, amelyben nagy szerepe van a kanyarulatok külső ívén megépített partbiztosításoknak, amelyek kiépítése legintenzívebben az 1930-as és 1960-as évek között zajlott (Kiss et al. 2008). A kőrakatok miatt a külső ív elmozdulása már az 1976. évi felmérés idejére is jelentősen lelassult (átl. 0,3 m/évre), míg a belső ív kétszer ilyen gyorsan (átl. 0,7 m/év) vándorolt. Mára azonban már mindkét part elmozdulása gyakorlatilag megállt, amely eredményeképpen a meder átlagszélessége 159 m-re csökkent. A meder szélességének változását az övzátonyok szélessége is tükrözi, hiszen míg az 1783. évi felmérésen létezö övzátonyok átlagosan 68 m szélesek voltak, addig a 2014. évi felmérésen már csak $19 \mathrm{~m}$ volt az átlagszélességük. A partbiztosítások hatása azonban nem csak a formák szélességén, de magasságukon is nyomon érhető. A kőrakatok kiépítése következtében megállt partelmozdulás az övzátonyok oldalirányú fejlődésének megállását is eredményezte. A hordalék felhalmozódása azonban a formák felszínén tovább folytatódik, de horizontális jellegét felváltotta a vertikális hordalék-akkumuláció, amely az övzátony-sorokat alkotó legutolsó tagok magasságának jelentős megnövekedését eredményezte, amely a 2,3-3,4 m-t is elérheti. Ez a magasságnövekedés a kanyarulatok 70\%-ánál tapasztalható. A folyamat eredményeképpen romlott a nagyvízi meder vízszállító-képessége is. A magas övzátonyformák jelenléte miatt manapság a formákat a korábban 1,2-1,8 évente visszatérö árvizek helyett már csak a 2-4,8 évente visszatérő árvizek öntik el és építik tovább.

Tehát a külső íven megépített partbiztosítások kiépítése következtében lelassuló, illetve megálló partelmozdulás miatt a belső íven is megindult a hordalék vertikális felhalmozódása, amely a part menti területek magasodását eredményezi, amihez a másik oldalon hozzájárul a folyóhátak magasodása is, illetve a meder bevágódása (Kiss et al. 2008). A partok magasságának növekedése egyes kutatások szerint kanyarulatvándorlás ütemének további csökkenését okozhatják (Ten Brinke et al. 1998, Wyżga 2001), ami elöre vetíti, hogy az övzátonyok klasszikus oldalirányú fejlődése előbb-utóbb leáll, és a vertikális feltöltődés révén egyre inkább a folyóhátakhoz válnak hasonlatossá.

Eredményeim szerint a belsö ivven zajló folyamatok hatással vannak a külső íven épülö folyóhátak fejlödésére is. A folyóhátak magassági és szélességi viszonyai kanyarulatfejlődési típusonként eltérnek, de különbségek fedezhetők fel az alacsonyodó és magasodó övzátonysorokkal szemben is. Az elforduló mozgással jellemezhető kanyarulatok mentén 0,7-1,2 m-rel magasabb és 229 m-rel szélesebb folyóhátak formálódtak, mint a megnyúló kanyarulatok mentén, amely véleményem szerint a kanyarulatok görbületi sugarával áll szoros kapcsolatban. Mivel az elforduló kanyarulatok jellemzően kis görbületi sugárral rendelkeznek, az ebből adódó nagyobb centrifugális erő magasabb és szélesebb folyóhátak kialakulását eredményezi.

Az övzátony-sorok fejlődési típusa tekintetében megállapítottam, hogy az alacsonyodó övzátonysorokkal szemben rendszerint magasabb és szélesebb folyóhátak fejlődnek, míg a magasodókkal szemben alacsonyabbak és keskenyebbek a formák. A folyóhátak ezen morfometriai különbségei a meder keresztszelvény-méretével, illetve a hullámtér szélességével hozhatók kapcsolatba. Az alacsonyodó övzátony-sorokkal rendelkező szakaszokon a meder rendre nagyobb szelvényterülettel rendelkezik, amely azt eredményezi, hogy az árvíz a többi területhez képest később boríthatja el a folyóhátat, az áradás tetőzéshez közeli időszakában, így a folyóhátak felszínén nagy mennyiségü hordalék halmozódhat fel. A magasodó övzátony-sorokkal szemben fejlődő alacsony és keskeny folyóhátak kialakulásának oka azonban a szük hullámtér, hiszen ezen kanyarulatok többsége esetében a hullámtér 200 m-nél szükebb a folyóhát felőli oldalán. Ez azt eredményezi, hogy árvizekkor a gát lábánál a vízáramlás felgyorsul (Sándor 2011), amely a szük hullámtéren megakadályozza a nagyobb mennyiségü hordalék lerakódását, azaz széles folyóhátak nem alakulhatnak ki. 


\section{Köszönetnyilvánítás}

Hálás köszönetet mondok témavezetőmnek, Dr. Kiss Tímeának az elmúlt években nyújtott szakmai támogatásáért és folyamatos bátorításáért. Tanácsaival sokat segített jelen dolgozat létrejöttében.

Köszönettel tartozom az ATIVIZIG munkatársainak a rendelkezésemre bocsátott adatokért.

Köszönöm az SZTE Természeti Földrajzi és Geoinformatikai tanszék dolgozóinak, illetve doktorandusz hallgatóinak a dolgozat megírásához adott szakmai tanácsaikat, továbbá köszönöm azon egyetemi hallgatók munkáját, akik a terepi mérések során a segítségemre voltak.

Végezetül köszönöm Páromnak, aki bátorítása mellett rengeteg szakmai tanáccsal is ellátott, illetve köszönettel tartozom Szüleimnek a folyamatos bíztatásukért. 


\section{Irodalomjegyzék}

Adams, P.N., Slingerland, R.L., Smith, N.D. 2004: Variations in natural levee morphology in anastomosed channel flood plain complexes. Geomorphology 61, 127-142.

Allen, J.R.L. 1965: A review of the origin and characteristic of recent alluvial sediments. Sedimentology 5/2, 89-191.

Álvarez-Iglesias, P., Quintana, B., Rubio, B., Pérez-Arlucea, M. 2007: Sedimentation rates and trace metal input history in intertidal sediments from San Simón Bay (Ría de Vigo, NW Spain) derived from ${ }^{210} \mathrm{~Pb}$ and ${ }^{137} \mathrm{Cs}$ chronology. Journal of Environmental Radioactivity 98/3, 229-250.

Amissah, G.J., Kiss, T., Fiala, K. 2017: Centurial changes in the depth conditions of a regulated river: case study of the Lower Tisza River, Hungary. Journal of Environmental Geography, 10/1-2, 41-51.

Andó M. 2002: A Tisza vízrendszer hidrogeográfiája. Szegedi Tudományegyetem Természeti Földrajzi Tanszék, Szeged, p. 186.

Antonarakis, A.S., Richards, K.S., Brasington, J., Muller, E. 2010: Determining leaf area index and leafy tree roughness using terrestrial laser scanning. Water Resources Research 46, W06510.

Arnold, E., Toran, L. 2018: Effects of bank vegetation and incision on erosion rates in an urban stream. Water 10, 482.

Asselman, N.E.M., Middelkoop, H., 1995: Floodplain sedimentation: quantities, patterns and processes. Earth Surface Processes and Landforms 20, 481- 499.

Asselman, N.E.M., Middelkoop, H., 1998: Temporal variability of contemporary floodplain sedimentation in the Rhine-Meuse Delta, the Netherlands. Earth Surface Processes and Landforms 23/7, 595-609.

Babák K. 2006: A Hármas-Körös hullámterének feltöltődése a szabályozások óta, Földrajzi Értesítő 55/3-4, 393-399.

Bain, D.J., Brush, G.S. 2005: Early chromite mining and agricultural clearance: opportunities for the investigation of agricultural sediment dynamics in the eastern Piedmont (USA). American Journal of Science 305/9, 957-981.

Baker, R.G., Schwert, D.P., Bettis, E.A., Chumbley, C.A. 1993: Impact of Euro-American settlement on a riparian landscape in northeast Iowa, Midwestern USA: an integrated approach based on historical evidence, floodplain sediments, fossil pollen, plant macrofossils and insects. The Holocene 3/4, 314-323.

Balogh J., Nagy I., Schweitzer F. 2005: A Közép-Tisza mente geomorfológiai adottságainak és a hullámterek feliszapolódásának vizsgálata mintaterületeken, Földrajzi Értesítő 54/1-2, 34-64.

Balogh K. 1991: Szedimentológia I. Akadémiai Kiadó, Budapest, 546 p.

Bathurst, J.C., Benson, I.A., Valentine, E.M., Nalluri, C. 2002: Overbank sediment deposition patterns for straight and meandering flume channels. Earth Surface Processes and Landforms 27/6, 659-665.

Beach, T. 1994: The fate of eroded soil: sediment sinks and sediment budgets of agrarian landscapes in southern Minnesota, 1851-1988. Annals of the Association of American Geographers 84/1, 5-28.

Berg, J.H. van Den, Gelder, A. van 1993: A New bedform stability diagram, with emphasis on the transition of ripples to plane bed in flows over fine sand and silt. Special Publications of the International Association of Sedimentologists 17, 11-21.

Biedenharn, D.S., Thorne, C.R., Watson, C.C. 2000: Recent morphological evolution of the Lower Mississippi River. Geomorphology 34, 227-249.

Bogárdi J. 1955: A hordalékmozgás elmélete. Akadémia Kiadó, Budapest, p. 543.

Bogárdi J. 1971: Vízfolyások hordalékszállítása. Akadémiai Kiadó, Budapest, p. 838. 
Bogdánfy Ö. 1901: Hidrológia. Pátria Irodalmi Vállalat és Nyomdai Részvénytársaság, Budapest, p. 165.

Borsy Z. 1972: Üledék- és morfológiai vizsgálatok a Szatmári-síkságon az 1970. évi árvíz után. Földrajzi Közlemények 96/1, 38-58.

Botár I., Károlyi Zs. 1971: A Tisza szabályozása. Vízügyi Történeti Füzetek 3, p. 78.

Braun M., Papp I., Korponai J., Lukács V., Gyulai I., Forró L., Hubay K., Szalóki I. 2010: A Tisza vízjárásának nyomai a Marótzugi-Holt-Tisza üledékében. Hidrológiai Közlöny 90/6, 20-22.

Braun M., Szalóki I., Posta J., Dezső Z. 2003: Üledék felhalmozódás sebességének becslése a Tisza hullámterében. MHT XXI. Vándorgyülésén elhangzott elöadások (CD kiadvány), 2/2, 1-11.

Brierley, G., Ferguson, R., Woolfe, K. 1997. What is a fluvial levee? Sedimentary Geology 114, 1-9.

Bristow, C.S., Skelly, R.L., Ethridge, F.G. 1999: Crevasse splays from the rapidly aggrading, sand-bed, braided Niobrara River, Nebraska: effect of base-level rise. Sedimentology 46, 1029-1047.

Brooks G.R. 2005: Overbank deposition along the concave side of the Red River meanders, Manitoba, and its geomorphic significance. Earth Surface Processes and Landforms 30, 1617-1632.

Burkham, D.E. 1976: Hydraulic effects of changes in bottom-land vegetation on three major floods, Gila River in south-eastern Arizona. Geological Survey Professional Paper 655-J, p. 17.

Catford, J.A., Jansson, R. 2014: Drowned, buried and carried away: effects of plant traits on the distribution of native and alien species in riparian ecosystems. New Pythologist 204/1, 19-36.

Cazanacli, D., Smith, N. 1998: A study of morphology and texture of natural levees Cumberland Marshes, Saskatchewan, Canada. Geomorphology 25, 43-55.

Challinor, J. 1946: Two contrasted types of alluvial deposits: with an illustration from the Rheidol Valley, Cardiganshire. Geological Magazine 83, 162-164.

Chorley R.J., Schumm S.A., Sugden D.E. 1985: Geomorphology. Methuen, London, p. 607.

Chow, V.T. 1959: Open channel hydraulics, McGraw-Hill, New York, United States, p. 364.

Chudaničová, M., Hutchinson, S.M. 2016: Magnetic signature of overbank sediment in industry impacted floodplains identified by data mining methods. Geophysical Journal International 207, 1106-1121.

Ciszewski, D., Grygar, T.M. 2016: A review of flood-related storage and remobilization of heavy metal pollutants in river systems. Water, Air, and Soil Pollution 227/7, 239.

Citterio, A., Piégay, H., 2009: Overbank sedimentation rates in former channel lakes: characterization and control factors. Sedimentology 56, 461-482.

Clark R.L. 1986: Pollen as a chronometer and sediment tracer, Burrinjuck Reservoir, Australia. Hydrobiologia 143, 63-69.

Colby, B.R. 1963: Fluvial sediments - a summary of source, transportation deposition, and measurement of sediment discharge. United States Geological Survey Bulletin, 1181A. p. 47.

Coleman, J.M. 1969: Brahmaputra River: Channel processes and sedimentation. Sedimentary Geology 3, 129-239.

Constantine, J.A., Pasternac, G.B., Johnson, M.L. 2005: Logging effects on sediment flux observed in a pollen-based record of overbank deposition in a northern California catchment. Earth Surface Processes and Landforms 30/7, 813-821.

Coon, W.F. 1998: Estimation of roughness coefficients for natural stream channels with vegetated banks. United States Geological Survey, Water-Supply Paper 2441. 
Corenblit, D., Tabacchi, E., Steiger, J., Gurnell, A.M. 2007: Reciprocal interactions and adjustments between fluvial landforms and vegetation dynamics in river corridors: A review of complementary approaches. Earth-Science Reviews 84, 56-86.

Costa, J.E. 1975: Effects of agriculture on erosion and sedimentation in the Piedmont Province, Maryland. Bulletin of the Geological Society of America 86/9, 1281-1286.

Csépes E., Bancsi I., Végvári P.. Aranyné Rózsavári A. 2003: Hordalékviszonyok vizsgálata a Tisza középső (Kisköre-Szolnok közötti) szakaszán. MHT XXI. Vándorgyülésén elhangzott előadások (CD kiadvány), 2/3. 1-10.

Daniel, J.F. 1971: Channel movement of meandering Indiana streams. USGS professional paper 732, 1-18.

Daniels, M.D., Rhoads, B.L. 2004: Effect of large woody debris configuration on threedimensional flow structure in two low-energy meander bends at varying stages. Water Resources Research 40, W11302.

Dawson, E.J. 1997: The dispersal, storage and remobilisation of heavy metals in the River Aire contaminated by urban and industrial wastes. Doktori $(\mathrm{PhD})$ értekezés, School of Geography, University of Leeds.

Dégen I. 1969: A szegedi árvíz - fordulópont a Tisza-völgy ármentesítésének történetében. In: A szegedi árvíz 1879. Vízügyi Történeti Füzetek 1., 7-18.

Delai, F., Kiss, T., Nagy, J. 2018: Field-based estimates of floodplain roughness along the Tisza River (Hungary): The role of invasive Amorpha fruticosa. Applied Geography, 90, 96-105.

Devi, T.B., Kumar, B. 2016: Flow characteristics in an alluvial channel covered partially with submerged vegetation. Ecological Engineering 94, 478-492.

Dezső Z., Szabó Sz., Bihari Á. 2009: Tiszai hullámtér feltöltődésének időbeli alakulása a ${ }^{137}$ Cs-izotóp gamma-spektrometriai vizsgálata alapján. In: Mócsy I., Szacsvai K., Urák I., Zsigmond A. (szerk): Proc. V. Kárpát-medencei Környezettudományi Konferencia, Sapientia, Kolozsvár, 443-438.

Didham, R.K., Tylianakis, J.M., Hutchison, M.A., Ewers, R.M., Gemmell, N.J. 2005: Are invasive species the drivers of ecological change? Trends in Ecology \& Evolution 20/9, 470-474.

Dietrich, W. E., Smith, J. D. 1983: Influence of the point bar on flow through curved channels. Water Resources Research 19, 1173-1192.

Dóka K. 1997: A Körös és a Berettyó vízrendszer szabályozása a 18-19. században (Egy táj átalakulása). Közlemények Békés megye és környéke történetéből 7., Gyula, p. 375.

Dumitraşcu, M., Grigorescu, I., Kucsicsa, G., Dragota, C., Năstase, M. 2014: Non-native and native invasive terrestrial plant species in Comana Natural Park. Case-studies: Amorpha fruticosa and Crataegus monogyna. Romanian Journal of Geography 55, 81-89.

Dunka S., Fejér L., Vágás I. 1996: A verítékes honfoglalás - A Tisza-szabályozás története. Vízügyi Múzeum, Levéltár és Könyvgyüjtemény, p. 215.

Erskine, W., McFadden, C., Bishop, P., 1992: Alluvial cutoffs as indicators of former channel conditions. Earth Surface Processes and Landforms 17, 23-37.

Eyles, R.J. 1977: Changes in drainage networks since 1820, Southern Tablelands, N.S.W. Australian Geographer 13/6, 377-386.

Faulkner, D.J., 1998: Spatially variable historical alluviation and channel incision in WestCentral Wisconsin. Annals of the Association of American Geographers 88/4, 666-685.

Félegyházi E. 2008: Ártéri lapályok elhagyott meder- és morotvatavainak feltöltődési sebessége. In: Kiss T.,Mezősi G. (szerk.): Recens geomorfológiai folyamatok sebessége Magyarországon. Földrajzi Tanulmányok 2, Szeged, 55-65.

Félegyházi P. 1929: A Tisza folyó jellegzetes szakaszainak és az egész Tiszának átlagosszelvény adataiban a szabályozás kezdete óta 1922. évig beállott változások és azok összehasonlítása. Vízügyi Közlemények 11/1, 93-102. 
Ferguson, R. J., Brierley, G. J. 1999: Levee morphology and sedimentology along the lower Tuross River, south-eastern Australia. Sedimentology 46/4, 627-648.

Fiala K. 2002: A Tisza felszínformáló tevékenységének vizsgálata Mindszentnél. Diplomamunka, Természeti Földrajzi és Geoinformatikai Tanszék, Szegedi Tudományegyetem, p. 49.

Fiala K., Kiss T. 2005: A középvízi meder változásai az 1890-es évektől az Alsó-Tiszán. Hidrológiai Közlöny, 85/3, 60-65.

Fiala K., Kiss T. 2006: A középvízi meder változásai az 1890-es évektől az Alsó-Tiszán II. Hidrológiai Közlöny, 86/5, 13-17.

Fiala K., Sipos Gy., Kiss T., Lázár M. 2007: Morfológiai változások és a vízvezető-képesség alakulása a Tisza algyői és a Maros makói szelvényében a 2000. évi árvíz kapcsán. Hidrológiai Közlöny, 87/5, 37-45.

Fisk, H.N. 1947: Fine grained alluvial deposits and their effects on the Mississippi River activity. Mississippi River Commission. Vicksburg, MS, p. 82.

Florsheim, J.L., Mount, J.F. 2003: Changes in lowland floodplain sedimentation processes: pre-disturbance to post-rehabilitation, Cosumnes River, CA. Geomorphology 56/3-4, 305323.

Freeman G.E., Rahmeyer W.H., Copeland R.R. 2000: Determination of resistance due to shrubs and woody vegetation. Technical Report, ERDC/CHL TR-00-25, US Army Engineer Research and Development Center, Vicksburg, MS.

Gábris Gy. 2016: A Körös-medence folyóvízi formavilága. Acta Climatologica et Chronologica, 50/B, 47-53.

Gábris Gy., Telbisz T., Nagy B. 2002: A tiszai hullámtér feltöltődésének vizsgálata DDM segítségével. In: Kiss T., Mezősi G. (szerk): Recens geomorfológiai folyamatok sebessége Magyarországon. Földrajzi Tanulmányok II., Szeged, 65-72.

Gagliano, S.M., Howard, P.G., 1984: The neck cutoff oxbow lake cycle along the Lower Mississippi River. In: Elliot, E.C.M. (szerk.): River Meandering. American Society of Civil Engineers, New York, 147-158.

Galema, A. 2009: Evaluation of vegetation resistance descriptors for floodplain management. Mater Thesis, University of Twente, Hollandia, p. 114.

Garcia Agudo, E. 1998: Global distribution of ${ }^{137} \mathrm{Cs}$ inputs for soil erosion and sedimentation studies. Use of ${ }^{137} \mathrm{Cs}$ in the study of soil erosion and sedimentation. International Atomic Energy Agency Publication IAEA-TECDOC-1028. IAEA, Vienna, 117 - 121.

Garcia, M.L., Basile, P.A., Riccardi, G.A., Rodriguez, J.F. 2015: Modeling extraordinary floods and sedimentological processes in a large channel-floodplain system of the Lower Paraná River (Argentina). International Journal of Sediment Research 30/2, 150-159.

Garssen, A.G., Baattrup-Pedersen, A., Voesenek, L.A.C.J., Verhoeven, J.T.A., Soons, M.B. 2015: Riparian plant community responses to increased flooding: a meta-analysis. Global Change Biology 21, 2881-2890.

Geerling, G.W., Kater, E., van den Brink, C., Baptsit, M.J., Ragas, A.M.J., Smits, A.J.M. 2008: Nature rehabilitation by floodplain excavation: The hydraulic effect of 16 years of sedimentation and vegetation succession along the Waal River, NL. Geomorphology 99/14, 317-328.

Gell, P., Fluin, J., Tibby, J., Hancock, G., Harrison, J., Zawadzki, A., Haynes, D., Khanum, S., Little, F., Walsh, B. 2009: Anthropogenic acceleration of sediment accretion in lowland floodplain wetlands, Murray-Darling Basin, Australia. Geomorphology 108/1-2, 122-126.

Ghimire, S.K., Higaki, D., Bhattarai, T.P. 2013: Estimation of soil erosion rates and eroded sediment in a degraded catchment of the Siwalik Hills, Nepal. Land 2, 370-391.

Gomez, B., Eden, D.N., Hicks, D.N., Trustrum, N.A., Peacock, D.H., Wilmshurst, J. 1999: Contribution of floodplain sequestration to the sediment budget of the Waipaoa River, New Zealand. In: Marriott, S.B., Alexander, J. (szerk.): Floodplains: Interdisciplinary Approaches. Geological Society, London, Special Publications 163, 69-88. 
Gönczy S., Molnár J. 2004: A Tiszai vízjárás változások valószínű okai. Müszaki Szemle 25, 9-15.

Gretener, B., Strömquist, L. 1987: Overbank sedimentation rates of fine grained sediments. A study of the recent deposition in the Lower River Fyrisån. Geografiska Annaler, Series A, Physical Geography 69/1, 139-146.

Gupta, A. 2007: Large Rivers: Geomorphology and management. Wiley, p. 713.

Gurnell, A.M., Gregory, K.J. 1995: Interactions between semi-natural vegetation and hydrogeomorphological processes. Geomorphology 13, 49-69.

Happ, S.C., Rittenhouse, G., Dobson, G.C. 1940: Some principles of accelerated stream and valley sedimentation. United States Department of Agriculture Technical Bulletin 695, p.188.

He, Q.,Walling, D.E. 1996: Use of fallout ${ }^{210} \mathrm{~Pb}$ measurements to investigate long-term rates and patterns of overbank sedimentation on the floodplain of lowland rivers. Earth Surface Processes and Landforms 21, 141-154.

Heller, F., Strzyszcz, Z., Mageira, T. 1998: Magnetic record of industrial pollution in forest soils of Upper Silesia, Poland. Journal of Geophysical Research: Solid Earth 103, 1776717774.

Henning, M. Hentschel, B. 2013: Sedimentation and flow patterns induced by regular and modified groynes on the River Elbe, Germany. Ecohydrology 6/4, 598-610.

Hernesz P. 2015: Késő-pleisztocén és holocén ártérfejlődés az Alsó-Tisza mentén. Doktori értekezés, Szegedi Tudományegyetem, Természeti Földrajzi és Geoinformatikai Tanszék. p. 118.

Hernesz P., Kiss T., Sipos Gy. 2015: Ártéri szintek és paleo-medrek: ártérfejlődés az AlsóTisza mentén. Földtani Közlöny 145/3, 273-286.

Hickin, E.J. 1969: A newly-identified process of point-bar formation in natural streams. American Journal of Science 267, 999-1010.

Hickin, E.J. 1974: The development of meanders in natural river-channels. American Journal of Science 274, 414-442.

Hickin, E.J. 1984: Vegetation and river channel dynamics. The Canadian Geographer 28/2, 111-126.

Hickin, E.J., Nanson, G.C. 1975: The character of channel migration on the Beatton River, Northeast British Columbia, Canada. Geological Society of America Bulletin 86/4, 487494.

Hindel, R., Schalich, J., De Vos, W., Ebbing, J., Swennen, R., Van Keer, I. 1996: Vertical distribution of elements in overbank sediment profiles from Belgium, Germany and The Netherlands. Journal of Geochemical Exploration 56/2, 105-122.

Hobo, N., Makaske, B., Middlekoop, H., Wallinga, J. 2010: Reconstruction of floodplain sedimentation rates: a combination of methods to optimize estimates. Earth Surface Processes and Landforms 35, 1499-1515.

Hooke, J.M. 2004: Cutoffs galore!: occurrence and causes of multiple cutoffs on a meandering river. Geomorphology 61, 225-238.

Hooke, J.M. 2007: Complexity, self-organisation and variation in behaviour in meandering rivers. Geomorphology 91/3, 236-258.

Hooke, J.M. 2016: Geomorphological impacts of an extreme flood in SE Spain. Geomorphology 263, 19-38.

Hooke, J.M., Harvey, A.M. 1983: Meander changes in relation to bend morphology and secondary flows. In: Collinson, J., Lewin, J. (szerk.): Modern and Ancient Fluvial Systems. International Association of Sediment Special Publication, 121-132.

Hooke, R.B. 1975: Distribution of sediment transport and shear stress in a meander bend. Journal of Geology 83/5, 543-565. 
Hudson, P., Heitmuller, F. 2003: Local- and watershed-scale controls on the spatial variability of natural levee deposits in a large fine-grained floodplain: Lower Pánuco Basin, Mexico. Geomorphology 56, 255-269.

Hudson, P.F., Kesel, R.H. 2000: Channel migration and meander-bend curvature in the lower Mississippi River prior to major human modification. Geology 28, 531-534.

Hudson, P.F., Middlekoop, H., Stouthamer, E. 2008: Flood management along the Lower Mississippi and Rhine Rivers (The Netherlands) and the continuum of geomorphic adjustment. Geomorphology 101, 209-236.

Hudson-Edwards, K.A., Macklin, M.G., Taylor, M.P. 1999: 2000 years of sediment-borne heavy metal storage in the Yorkshire Ouse Basin, NE England, UK. Hydrological Processes 13/7, 1087-1102.

Hughes, A.O., Croke, J.C., Pietsch, T.J., Olley, J.M. 2010: Changes in the rates of floodplain and in-channel bench accretion in response to catchment disturbance, central Queensland, Australia. Geomorphology 114, 338-347.

Hupp C.R., Noe G.B., Schenk E.R. 2010: Floodplains, equilibrium, and fluvial geomorphic impacts of human alterations. $2^{\text {nd }}$ Joint Federal Interagency Conference, Las Vegas, NV, 112.

Hupp, C.R., Bornette, G., 2003: Vegetation as a tool in the interpretation of fluvial geomorphic processes and landforms in humid temperate areas. In: Kondolf, M., Piegay, H. (szerk.): Tools in Geomorphology. John Wiley and Sons, UK, 269-288.

Hupp, C.R., Demas, C.R., Kroes, D.E., Day, R.H., Doyle, T.W. 2008: Recent sedimentation patterns within the central Atchafalaya Basin, Louisiana. Wetlands 28/1, 125-140.

Hupp, C.R., Schenk, E.R., Kores, D.E., Willard, D.A., Townsand, P.A., Peet, R.K. 2015: Patterns of floodplain sediment deposition along the regulated lower Roanoke River, North Carolina: Annual, decadal, centennial scales. Geomorphology 228, 666-680.

Ihrig D. 1973: A magyar vízszabályozás története. Országos Vízügyi Hivatal, Budapest, p. 398.

Ishii, Y., Hori, K. 2016: Formation and infilling of oxbow lakes in the Ishikari lowland, northern Japan. Quaternary International 397, 136-146.

Iványi B. 1948: A Tisza kisvízi szabályozása. Vízügyi Közlemények 30/2, 131-159.

Jackson, R.G. 1976: Depositional model of point bars in the lower Wabash River. Journal of Sedimentary Research 46/3, 579-594.

Jahns, R.H. 1947: Geologic Features of the Connecticut Valley, Massachusetts, as related to recent floods. U.S. Geological Survey, Water Supply Paper 996, p. 158.

Jakucs L. 1982: Az árvizek gyakoriságának okai és annak tényezői a Tisza vízrendszerében. Földrajzi Közlemények 30, 212-236.

James, C.S. 1985: Sediment transfer to overbank sections. Journal of Hydraulic Research $23 / 5,435-452$.

Järvelä, J. 2004: Determination of flow resistance caused by non-submerged woody vegetation. International Journal of River Basin Management 2/1, 61-70.

Johannesson, H., Parker G. 1985: Computer simulated migration of meandering rivers in Minnesota. St. Anthony Falls Laboratory Project Reports 242, University of Minnesota. p. 89.

Kaase, C.T., Kupfer, J.A. 2016: Sedimentation patterns across a Coastal Plain floodplain: The importance of hydrogeomorphic influences and cross-floodplain connectivity. Geomorphology 269, 43-55.

Károlyi Z. 1960: A Tisza mederváltozásai, különös tekintettel az árvízvédelemre. Vízgazdálkodási Tudományos Kutató Intézet, Tanulmányok és Kutatási Eredmények 8. szám, Budapest, p. 102.

Kaushik, A., Jain, S., Dawra, J., Sahu, R., Kaushik, C.P. 2001: Heavy metal pollution of River Yamuna in the industrially developing state of Haryna. Indian Journal of Environmental Health 43/4, 164-168. 
Keller P., Marsovszki G. 1992: Az ATIVIZIG kezelésébe tartozó Tisza szakasz általános szabályozási terve és annak megvalósulását elősegítő tudományos vizsgálatok eredményei. MHT X. Országos Vándorgyülése, Szeged, 152-170.

Kenyon, C., Rutherfurd, I.D. 1999: Preliminary evidence for pollen as an indicator of recent floodplain accumulation rates and vegetation changes: the Barmah-Millewa Forest. Environmental Management 24/3, 359-367.

Kesel, R.H. 2003: Human modifications to the sediment regime of the Lower Mississippi River flood plain. Geomorphology 56/3-4, 325-334.

Kesel, R.H., Dunne, K.C., McDonald, R.C., Allison, K.R., Spicer, B.E. 1974: Lateral erosion and overbank deposition on the Mississippi River in Louisiana caused by 1973 flooding. Geology 2/9, 461-464.

Kim, H.S., Nabi, M., Kimura, I., Shimizu, Y. 2015: Computational modelling of flow and morphodynamics through rigid-emergent vegetation. Advances in Water Resources 84, 6486.

Kiss T. 2014: Fluviális folyamatok antropogén hatásra megváltozó dinamikája: egyensúly és érzékenység vizsgálata folyóvízi környezetben. Akadémiai doktori értekezés, Szeged, p. 163.

Kiss T., Balogh M., Fiala K., Sipos Gy. 2018b: Morphology of fluvial levee series along a river under human influence, Maros River, Hungary. Geomorphology 303, 309-321.

Kiss T., Fejes A. 2000: Flood caused sedimentation on the foreshore of the River Tisza. ACTA Geographica Szegediensis 37, 51-54.

Kiss T., Fiala K., Sipos Gy. 2008: Alterations of channel parameters in response to river regulation works since 1840 on the Lower Tisza River (Hungary). Geomorphology, 98, 96110 .

Kiss T., Hajdu I.Z. 2015: Morfológiai változások vizsgálata a Felső-Tisza ukrán-magyar szakaszán. Hidrológiai Közlöny, 95/2, 49-54.

Kiss T., Horváth R., Fiala K. 2018a: Szabályozások hatására megváltozó medermintázat az Alsó-Tiszán: El fognak tünni az övzátonyok? In: Fazekas I., Kiss E., Lázár I. (szerk.): Földrajzi Tanulmányok 2018, Debrecen, 259-262.

Kiss T., Nagy J., Fehérváry I., Vaszkó Cs. 2019c: (Mis)management of floodplain vegetation: The effect of invasive species on vegetation roughness and flood levels. Science of The Total Environment 686, 931-945.

Kiss T., Oroszi V., Sipos Gy., Fiala K., Benyhe B. 2011: Accelerated overbank sedimentation after nineteenth century river regulation works: A case study on the Maros River, Hungary. Geomorphology 135, 191-202.

Kiss T., Sipos Gy. 2009: Dendrológia alkalmazása a geomorfológiai kutatások során: a szigetvándorlás vizsgálata a Maros magyarországi szakaszán. Földrajzi Közlemények 133/1, 13-21.

Kiss T., Sipos Gy., Fiala K. 2002: Recens üledék-felhalmozódás sebességének vizsgálata az Alsó-Tiszán, Vízügyi Közlemények 84/3, 456-472.

Kiss T.; Fiala K.; Sipos Gy.; Szatmári G. 2019a: Long-term hydrological changes after various river regulation measures: are we responsible for flow extremes? Hydrology Research, 50/2, 417-430.

Kiss, T., Amissah, G.J., Fiala, K. 2019b: Bank processes and revetment erosion of a large lowland river: Case study of the Lower Tisza River, Hungary. Water 11/6, 1313.

Klasz, G., Reckendorfer, W., Gabriel, H., Baumgartner, C., Schmalfuss, R., Gutknecht, D. 2014: Natural levee formation along a large and regulated river: The Danube in the National Park Donau-Auen, Austria. Geomorphology 215, 20-33.

Knighton D. 1998: Fluvial forms and processes. Arnold Publ., Oxford, p. 383.

Knox, J.C. 1987: Historical valley floor sedimentation in the Upper Mississippi Valley. Annals of the Association of American Geographers 77, 224-244. 
Knox, J.C. 2006: Floodplain sedimentation in the Upper Mississippi Valley: natural versus human accelerated. Geomorphology 79/3-4, 286-310.

Koncsos L., Kozma Zs. 2007: A hullámtéri feltöltődés becslése a Tisza magyarországi szakaszán. Hidrológiai Közlöny 87/5, 59-63.

Konecsny K. 2000: Az országhatáron túli tájátalakítás hatása az Alföld vízviszonyaira. In: Pálfai I. (szerk.): A víz szerepe és jelentősége az Alföldön. A Nagyalföld Alapítvány Kötetei 6, 27-45.

Konrad, C.P. 2012: Reoccupation of floodplains by rivers and its relation to the age structure of floodplain vegetation. Journal of Geophysical Research 117/G4.

Konsoer, K.M., Richards, D., Edwards, B. 2016: Planform evolution of neck cutoffs on elongate meander loops, White River, Arkansas, USA. River Flow 2016: Iowa City, USA, July 11-14, 1730-1735.

Kozák M., Rátky I. 1999: Hullámtér szélességének és beépítettségének hatása az árvízszintekre. Vízügyi Közlemények 81, 311-317.

Kroes D.E., Hupp C.R. 2010: The effect of channelization on floodplain sediment deposition and subsidence along the Pocomoke River, Maryland. Journal of the American Water Resources Association 46/4, 686-699.

Kvassay J. 1902: A szabályozások hatása a folyók vízjárására Magyarországon, Vízügyi Közlemények 15, 7-27.

Laczay I. 1982: A folyószabályozások tervezésének morfológiai alapjai, Vízügyi Közlemények, 64/2, 235-254.

Lageweg, W.I. van de, Dijk, W.M. van, Baar A.W., Rutten, J., Kleinhans, M. G. 2014: Bank pull or bar push: what drives scroll-bar formation in meandering rivers?. Geology 5/ 42, 319-322.

Lambert, C.P., Walling, D.E. 1987: Floodplain sedimentation: A preliminary investigation of contemporary sedimentation within the lower reaches of the River Culm, Devon, UK. Geografiska Annaler, Series A, Physical Geography 69/3-4, 393-404.

Lang, A. 2008: Recent advances in dating and source tracing of fluvial deposits. IAHS Puplications 325, 3-12.

Lászlóffy W. 1982: A Tisza. Vízi munkálatok és vízgazdálkodás a Tisza vízrendszerében. Akadémiai Kiadó, Budapest, 610 p.

Lecce, S.A. 1997: Spatial patterns of historical overbank sedimentation and floodplain evolution, Blue River, Wisconsin. Geomorphology 18, 265-277.

Leopold, L.B., Wolman, M.G., Miller, J.P., 1964: Fluvial Processes in Geomorphology. Freeman, San Francisco, p. 522.

Lewin, J. 1978: Floodplain geomorphology. Progress in Physical Geography 2/3, 408-437.

Lewin, J., Ashworth, P.J. 2014: The negative relief of large river floodplains. Earth-Science Reviews 129, 1-23.

Lewis, G.W., Lewin, J., 1983: Alluvial cutoffs in Wales and the Borderlands. In: Collinson, J.D., Lewin, J. (szerk.): Modern and Ancient Fluvial Systems, Special Publications of the International Association of Sedimentologists 6, 145-154.

Lóczy D., Kis É., Schweitzer F. 2009: Local flood hazards assessed from channel morphometry along the Tisza River in Hungary. Geomorphology, 113, 200-209.

Lóczy D., Veress M. 2005: Geomorfológia I. Földfelszíni folyamatok és formák. Dialóg Campus Kiadó, Budapest-Pécs. 93-94.

Lóki J., Szabó J., Konecsny K., Szabó G., Szabó Sz. 2004: Az erdősültség és az árhullámok kapcsolata a Felső-Tisza-vidéken. II. Magyar Földrajzi Konferencia (CD kiadvány), Szeged, 1-21.

Lopez, F., Garcia, M.H. 2001: Mean flow and turbulence structure of open-channel flow through non-emergent vegetation. Journal of Hydraulic Engineering 127/5, 392-402.

Magilligan, F.J. 1985: Historical floodplain sedimentation in the Galena River Basin, Wisconsin and Illinois. Annals of the Association of American Geographers 75/4, 583-594. 
Magilligan, F.J. 1992: Sedimentology of a fine-grained aggrading floodplain. Geomorphology 4/6, 393-408.

Magilligan, F.J., Nislow, K.H. 2005: Changes in hydrologic regime by dams. Geomorphology 71/1-2, 61-78.

Magilligan, F.J., Phillips, J.D., James, L.A., Gomez, B. 1998: Geomorphic an sedimentological controls on the effectiveness of an extreme flood. Journal of Geology 106, 87-95.

Marosi S., Somogyi S. 1990: Magyarország kistájainak katasztere I. MTA Földrajztudományi Kutató Intézet, Budapest, p. 479.

Marren, P.M., Grove, J.R., Webb, J.A., Stewardson, M.J. 2014: The potential for dams to impact lowland meandering river floodplain geomorphology. The Scientific World Journal 2014/6, 24.

Marriott, S. 1992: Textural analysis and modelling of a flood deposit: River Severn, U.K. Earth Surface Processes and Landforms 17/7, 687-697.

Marron, D.C. 1992: Floodplain storage of mine tailings in the Belle Fourche River System: A sediment budget approach. Earth Surface Processes and Landforms 17/7, 675-685.

Martin, C.W. 2000: Heavy metal trends in floodplain sediments and valley fill, River Lahn, Germany. Catena 39/1, 53-68.

Matisoff, G. 2014: ${ }^{210} \mathrm{~Pb}$ as a tracer for soil erosion, sediment source area identification and particle transport in the terrestrial environment. Journal of Environmental Radioactivity 138, 343-354.

Mertes, L.A.K. 1994: Rates of flood-plain sedimentation on the central Amazon River. Geology 22, 171-174.

Micheli, E.R., Kirchner, J.W. 2002: Effects of wet meadow riparian vegetation on streambank erosion. 1. Remote sensing measurements of stream bank migration and erodibility. Earth Surface Processes and Landforms 27/6, 627-639.

Micheli, E.R., Kirchner, J.W., Larsen, E.W. 2004: Quantifying the effects of riparian forest versus agricultural vegetation on river meander migration rates, central Sacramento River, California, USA. River Research and Applications 20/5, 537-548.

Mihály B., Botta-Dukát Z. 2004: Özönnövények I., Természet BÚVÁR Alapítvány Kiadó, Budapest, p. 366.

Mike K. 1991: Magyarország ősvízrajza és felszíni vizeinek története. Aqua Kiadó, Budapest, p. 698.

Mizugaki, S., Nakamura, F., Araya, T. 2006: Using geomorphology and ${ }^{137} \mathrm{Cs}$ and ${ }^{210} \mathrm{~Pb}$ radiochronology to estimate recent changes in sedimentation rates in Kushiro Mire, Northern Japan, resulting from land use change and river channelization. Catena 68/1, 2540.

Motta, D., Langendoen, E.J., Abad, J.D., García M.H. 2014: Modification of meander migration by bank failures. Journal of Geophysical Research: Earth Surface 119, 10261042.

Mücher, H.J., Slotboom, R.T., ten Veen, W.J. 1990: Palynology and micromorphology of a manmade soil. A reconstruction of the agricultural history since late-medieval times of the Posteles in the Netherlands. Catena 17, 55-67.

Mullins, C.E. 1977: Magnetic susceptibility of the soil and its significance in soil science review. European Journal of Soil Science 28/2, 223-246.

Nagy I., Schweitzer F., Alföldi L. 2001: A hullámtéri hordalék-lerakódás (övzátony). Vúzügyi Közlemények 83/4, 539-564.

Nanson, G.C., Croke, J.C. 1992: A genetic classification of floodplains. Geomorphology 4, 459-486.

Nanson, G.C., Hickin, E.J. 1983: Channel migration and incision on the Beatton River. Journal of Hydraulic Engineering 109, 327-337. 
Nepf, H.M., Vivoni, E.R. 2000: Flow structure in depth-limited, vegetated flow. Journal of Geophysical Research 105, 28527-28546.

Omengo, F.O., Alleman, T., Geeraert, N., Bouillon, S., Govers, G. 2016: Sediment deposition patterns in a tropical floodplain, Tana River, Kenya. Catena 143, 57-69.

Opperman, J.J., Luster, R., McKenney, B.A., Roberts, M., Meadows, A.W., 2010: Ecologically functional floodplains: connectivity, flow regime, and scale. Journal of the American Water Resources Association 46/2, 211-226.

Oroszi V. 2008: Egy árvíz okozta ártérfeltöltődés: a Maros 2006. évi áradása által lerakott hullámtéri üledék vizsgálata. In: Kiss T., Mezősi G. (szerk.): Recens geomorfológiai folyamatok sebessége Magyarországon. Szeged, 73-83.

Oroszi V. 2009: Hullámtér-fejlődés vizsgálata a Maros magyarországi szakaszán. Doktori értekezés, Szegedi Tudományegyetem, Természeti Földrajzi és Geoinformatikai Tanszék. p. 127.

Oroszi V., Kiss T. 2004: Folyószabályozás hatására felgyorsult hullámtér-feltöltődés vizsgálata a Maros magyarországi szakaszán. II. Magyar Földrajzi Konferencia (CD kiadvány), Szeged, 1-20.

Oroszi V., Kiss T., Botlik A. 2006b: A 2005. évi tavaszi áradás üledékfelhalmozó hatása a Maros hullámterén. III. Magyar Földrajzi Konferencia (CD kiadvány), Budapest, 1-10.

Oroszi V., Sándor A., Kiss T. 2006a: A 2005. tavaszi árvíz által okozott ártérfeltöltődés a Maros és a Közép-Tisza egy rövid szakasza mentén. In: Kiss A., Mezősi G.,Sümegi Z. (szerk.): Táj, környezet és társadalom. Ünnepi tanulmányok Keveiné Bárány Ilona professzor asszony tiszteletére. Szeged, 551-561.

Osterkamp, W.R., Hupp, C.R. 2010: Fluvial processes and vegetation - Glimpses of the past, the present, and perhaps the future. Geomorphology 116, 274-285.

Pease, P., Lecce, S., Gares, P., Rigsby, C. 2007: Heavy metal concentrations in sediment deposits on the Tar River floodplain following Hurricane Floyd. Environmental Geology 51/7, 1103-1111.

Pécsi M. 1969: A tiszai Alföld. Akadémiai Kiadó, Budapest, p. 382.

Pennington, W., 1979: The origin of pollen in lake sediments: an enclosed lake compared with one receiving inflow streams. New Phytologist 83/1, 189-213.

Petrovský, E., Kapička, A., Jordanova, N., Knab, M., Hoffmann, V. 2000: Low-field magnetic susceptibility: a proxy method of estimating increased pollution of different environmental systems. Environmental Geology 39, 312-318.

Pierce, A.R., King, S.L. 2008: Spatial dynamics of overbank sedimentation in floodplain systems. Geomorphology 100, 256-268.

Pizzuto, J.E. 1987: Sediment diffusion during overbank flows. Sedimentology 34/2, 301-317.

Pizzuto, J.E, Skalak, K., Person, A., Benthem, A. 2016: Active overbank sedimentation during the last century, South River, Virginia. Geomorphology 257, 164-178.

Planty-Tabacchi, A.M., Tabacchi, E., Naimann, R.J., Deferrari, C., Decamps, H. 1996: Invasibility of species-rich communities in riparian zones. Conservation Biology 10/2, 598-607.

Provansal, M., Villiet, J., Eyrolle, F., Raccasi, G., Gurriaran, R., Antonelli, C. 2010: Highresolution evaluation of recent bank accretion rate of the managed Rhone: A case study by multi-proxy approach. Geomorphology 117/3-4, 287-297.

Pyšek, P., Prach, K. 1993: Plant invasions and the role of riparian habitats: a comparison of four species alien to Central Europe. Journal of Biogeography 20, 413-420.

Pyšek, P., Prach, K. 1994. How important are rivers for supporting plant invasion? Ecology and Management of Invasive Riverside Plants 19, 19-26.

Rácz L. 1999: Climate history of Hungary since 16th century: past, present and future. KRTK Institute for Regional Studies, Discussion Papers, 28, 5-158.

Rakonczai J, Kozák P. 2009: Az Alsó-Tisza-vidék és a Tisza. Földrajzi Közlemények 133/4, 385-395. 
Rátky I., Farkas P. 2003: A növényzet hatása a hullámtér vízszállító képességére. Vízügyi Közlemények 85/2, 246-264.

Rátky I., Rátky É. 2009: Lehetőséges a Tisza vízszállító-képességének javítására. Hidrológiai Közlöny 89/1, 35-44.

Ree, W.O., Crow, F. 1977: Friction factors for vegetated waterways of small slope. Technical Report Publication S-151, US Department of Agriculture, Agricultural Research Service.

Renshaw, C.E., Abengoza, K., Magilligan, F.J., Dade, W.B., Landis, J.D. 2014: Impact of flow regulation on near-channel floodplain sedimentation. Geomorphology 205, 120-127.

Ritchie, J.C., Finney, V.L., Oster, K.J., Ritchie, C.A. 2004: Sediment deposition in the flood plain of Stemple Creek Watershed, northern California. Geomorphology 61/3-4, 347-360.

Ross, K.M., Hupp, C.R., Howard, A.D. 2004: Sedimentation in floodplains of selected tributaries of the Chesapeake Bay. American Geophysical Union, Water Science and Application 8, 187-208.

Russell, C.E., Mountney, N.P., Hodgson, D.M., Colombera, L. 2018: A novel approach for prediction of lithological heterogeneity in fluvial point-bar deposits from analysis of meander morphology and scroll-bar pattern. In: Ghinassi, M., Colombera, L., Mountney, N.P. and Reesink, A.J.H., (szerk.): Fluvial Meanders and Their Sedimentary Products in the Rock Record. International Association of Sedimentologists Series Special Publication, 385-418.

Rustomji, P., Pietsch, T. 2007: Alluvial sedimentation rates from southeastern Australia indicate post-settlement landscape recovery. Geomorphology 90/1-2, 73-90.

Samuels, P.G., Bramley, M.E., Evans, E.P., 2002: A new conveyance estimation system. 37th Annual Conference of River and Coastal Engineers, July 2002, University of Keele, UK. 1-11.

Sándor A. 2011: A hullámtér feltöltődés folyamatának vizsgálata a Tisza középső és alsó szakaszán. Doktori értekezés. Szegedi Tudományegyetem, Természeti Földrajzi és Geoinformatikai Tanszék, p. 121.

Sándor A., Kiss T. 2006a: A hullámtéri üledék-felhalmozódás mértékének vizsgálata a Közép- és az Alsó-Tiszán. Hidrológiai Közlöny, 86/2, 58-62.

Sándor A., Kiss T. 2006b: A hullámtéri akkumuláció meghatározása mágneses szuszceptibilitás és röntgensugaras mérések segítségével, közép-tiszai mintaterületeken. III. Magyar Földrajzi Konferencia (CD kiadvány), 1-10.

Sándor A., Kiss T. 2007: A 2006. tavaszi árvíz okozta feltöltődés mértéke és az azt befolyásoló tényezők vizsgálata a Közép-Tiszán, Szolnoknál. Hidrológiai Közlöny, 87/4, 19-24.

Sándor A., Kiss T. 2008: A területhasználat-változás hatása az üledék-felhalmozódásra, közép-tiszai vizsgálatok alapján. IV. Magyar Földrajzi Konferencia (CD kiadvány), 1-6.

Schenk, E.R., Hupp, C.R., Gellis, A., Noe, G. 2013: Developing a new stream metric for comparing stream function using a bank-floodplain sediment budget: a case study of three Piedmont streams. Earth Surface Processes and Landforms 38, 771-784.

Schnitzler, A., Hale, B. W., Alsum, E. M. 2007: Examining native and exotic species diversity in European riparian forests. Biological Conservation 138, 146-156.

Schweitzer F. 2001a: A magyarországi folyószabályozások geomorfológiai vonatkozásai. Folyóink hullámtereinek fejlődése, kapcsolatuk az árvizekkel és az árvízvédelmi töltésekkel. Földrajzi Értesítő 50/1-4, 63-72.

Schweitzer, F., 2001b. Társadalom és környezet: gátépítés vagy hullámtérbővítés: folyóink hullámtereinek fejlődése, kapcsolatuk az árvizekkel és az árvízvédelmi töltésekkel. In: Ilyés Z., Keményfi R. (szerk.): A táj megértése felé: tanulmányok a 75 éves Pinczés Zoltán professzor tiszteletére. Debrecen-Eger, 95-103.

Schweitzer F., Nagy I., Alföldi L. 2002: Jelenkori övzátony (parti gát) képződés és hullámtéri lerakódás a Közép-Tisza térségében. Földrajzi értesítő 51/3-4, 257-278. 
Sedláček, J., Bábek, O., Kielar, O. 2016: Sediment accumulation rates and high-resolution stratigraphy of recent fluvial suspension deposits in various fluvial settings, Morava River catchment area, Czech Republic. Geomorphology 254, 73-87.

Sharpe, R.G., James, C.S. 2007: Deposition of sediment from suspension in emergent vegetation. Water 32/2, 211-218.

Sipos Gy., Kiss T., Fiala K. 2007: Morphological alterations due to channelization along the Lower Tisza and Maros Rivers (Hungary). Geographica Fisica e Dinamica Quaternaria, 30, 239-247.

Smith, L.M. 1996: Fluvial geomorphic features of the Lower Mississippi alluvial valley. Engineering Geology 45/1-4, 139-165.

Somogyi S. 2000: A XIX. századi folyószabályozások és ármentesítések földrajzi és ökológiai hatásai. MTA Földrajztudományi Kutató Intézet, Budapest, p. 302.

Steiger, J., Gurnell, A.M. 2003: Spatial hydrogeomorphological influences on sediment and nutrient deposition in riparian zones: observations from the Garonne River, France. Geomorphology 49, 1-23.

Steiger, J., Gurnell, A.M., Ergenzinger, P., Snelder, D. 2001: Sedimentation in the riparian zone of an incising river. Earth Surface Processes and Landforms 26, 91-108.

Steiger, J., Gurnell, A.M., Goodson, J.M. 2003: Quantifying and characterizing contemporary riparian sedimentation. River Research and Applications 19, 335-352.

Strick, R.J.P., Ashworth, P.J., Awcock, G., Lewin, J. 2018: Morphology and spacing of meander scrolls. Geomorphology 310, 57-68.

Strunk, H. 1997: Dating of geomorphological processes using dendrogeomorphological methods. Catena 31, 137-151.

Sümeghy B. 2014: A Maros hordalékkúp fejlődéstörténeti rekonstrukciója. Doktori értekezés, Szegedi Tudományegyetem, Természeti Földrajzi és Geoinformatikai Tanszék. p. 98.

Sümeghy B., Kiss T., Sipos Gy., Tóth O. 2013: A Maros hordalékkúp felső-pleisztocénholocén fluviális képződményei. Földtani Közlöny 143/3, 265-278.

Sun, T., Meakin, P., Jøssang, T., Schwarz, K. 1996: A simulation model for meandering rivers. Water Resources Research 32, 2937-2954.

Svingor É. 2012: A C-14 kormeghatározás alapjai és problémái. Archeometriai Műhely 3, 135-146.

Szabó Sz., Molnár L.Sz., Gosztonyi Gy., Posta J., Prokisch J. 2008: A nehézfémszennyezettség vizsgálata egy felső-tiszai holtmeder környezetében. In: Demeter G. (szerk.): Geographia Generalis et specialis. Debrecen, 255-260.

Szigetvári Cs., Tóth T. 2012: Cserjés gyalogakác. In: Csiszár, Á. (szerk.) Inváziós növényfajok Magyarországon, Nyugat-magyarországi Egyetem Kiadó, 121-126.

Szlávik L. 2000: Az Alföld árvízi veszélyeztetettsége. In: Pálfai I.(szerk.): A víz szerepe és jelentősége az Alföldön. A Nagyalföld Alapítvány Kötetei 6, 64-84.

Szlávik L. 2001: A Tisza-völgy árvízvédelme és fejlesztése. I. Magyar Földrajzi Konferencia (CD kiadvány), Szeged, 1-52.

Takuya, U., Keiichi, K., Kohji, M. 2014: Experimental and numerical study on hydrodynamics of riparian vegetation. Journal of Hydrodynamics 26/5, 796-806.

Tamás E.A., Kalocsa B. 2003: A Rezéti-Duna feltöltődésének vizsgálata. In: Somogyvári O. (szerk.): Élet a Duna-ártéren - természetvédelemröl sokszemközt. Pécs, 43-49.

Tang, Q., Bao, Y., He, X., Zhou, H., Cao, Z., Gao, P., Zhong, R., Hu, Y., Zhang, X. 2014: Sedimentation and associated trace metal enrichment in the riparian zone of the Three Gorges Reservoir, China. Science of the Total Environment 479-480, 258-266.

Taylor, K., Owens, P.N. 2009: Sediments in urban river basins: A review of sedimentcontaminant dynamics in an environmental system conditioned by human activities. Journal of Soils and Sediments 9, 281-303. 
Ten Brinke, W.B.M., Schoor, M.M., Sorber, A.M., Berendsen, H.J.A. 1998: Overbank sand deposition in relation to transport volumes during large-magnitude floods in the Dutch sand-bed Rhine river system. Earth Surface Processes and Landforms 23/9, 809-824.

Terasmae, J. 1984: Radiocarbon dating: Some problems and potential developments. Developments in Palaeontology and Stratigraphy 7, 1-15.

Thompson, R., Morton, D.J. 1979: Magnetic susceptibility and particle-size distribution in recent sediments of the Loch Lomond drainage basin, Scotland. Journal of Sedimentary Research 49/3, 801-811.

Thonon, I., Middlekoop, H., van der Perk, M. 2007: The influence of floodplain morphology and river works on spatial patterns of overbank deposition. Netherlands Journal of Geosciences 86/1, 63-75.

Thorne, C.R. 1991: Bank erosion and meander migration of the Red and Mississippi Rivers, USA. In: Van-de-Ven, F.H.M., Gutknecht, D., Loucks, D.P., Salewicz, K.A. (szerk.): Hydrology for the Water Management of Large River Basins (Proceedings of the Vienna Symposium, August 1991). International Association of Hydrological Sciences, 301-313.

Tiron, L.J., Le Coz, J., Provansal, M., Panin, N., Raccasi, G., Dramais, G., Dussouillez, P. 2009: Flow and sediment processes in a cutoff meander of the Danube Delta during episodic flooding. Geomorphology 106/3-4, 186-197.

Toonen, W.H.J., Kleinhans, M.G., Cohen, K.M., 2012: Sedimentary architecture of abandoned channel fills. Earth Surface Processes and Landforms 37, 459-472.

Török I.Gy. 2000: Az alföldi folyók hullámterének szerepe és hasznosítása. In: Pálfai I. (szerk.): A víz szerepe és jelentősége az Alföldön. A Nagyalföld Alapítvány Kötetei 6, 125-132.

Uddin, M., Rahman, M. 2012: Flow and erosion at a bend in the braided Jamuna River. International Journal of Sediment Research 27/4, 498-509.

Vágás I. 1982: A Tisza árvizei. Vízügyi Dokumentációs és Továbbképző Intézet, Budapest, $283 \mathrm{p}$.

Vágás I. 2001: Az ezredforduló árhullámai a Tiszán. Magyar Tudomány, 48/8, 958-966.

Vágás I. 2003: Az 1998. novemberi árhullám hidrológiai értékelése a Tisza-völgyi árvizek sorában. In: Szlávik L. (szerk.): Az 1998. évi árvíz. Vízügyi Közlemények különszám 1, 85-91.

Vágás I., Bezdán M. 2015: A Tisza és árvizei. Szeged, p. 189.

Vargas-Luna, A., Crosato, A., Uijttewaal, W.S.J. 2015: Effects of vegetation on flow and sediment transport: comparative analyses and validation of predicting models. Earth Surface Processes and Landforms 40, 157-176.

Vass R. 2007: Adalékok a mentett ártéri és hullámtéri feltöltődéshez a Beregi-síkon a 2001. évi tiszai árvíz tükrében. Acta geographica ac geologica et meteorologica Debrecina. Geológia, geomorfológia, természetföldrajz sorozat, 2. kötet, 229-235.

Vass R., Szabó G., Szabó J. 2009a: Hullámtéri feltöltődés vizsgálata geoinformatikai módszerekkel a Felső-Tisza vidéken. A HunDEM 2009 és a GeoInfo 2009 konferencia és kerekasztal válogatott tanulmányai. 1-10.

Vass R., Szabó J., Tóth Cs. 2009b: Ártéri morfológia és akkumuláció kapcsolata felső-tiszai mintaterületeken. In: Kiss T. (szerk): Természetföldrajzi folyamatok és formák, 1-11.

Végh Zs. 2016: Recens ártérfeltöltődés és a növényzet kapcsolatának vizsgálata az Alsó-Tisza mindszenti szakaszán. Diplomamunka, Szegedi Tudományegyetem, Természeti Földrajzi és Geoinformatikai Tanszék. p. 55.

Walling, D.E., Bradley, S.B. 1989: Rates and patterns of contemporary floodplain sedimentation: a case study of the River Culm, Devon, UK. Geojournal 19, 53-62.

Walling, D.E., Bradley, S.B., Lambert, C.P. 1986: Conveyance losses of suspended sediment within a floodplain system. IAHS Publications 159, 119- 131. 
Walling, D.E., Collins, A.E., Sichingabula, H.M. 2003: Using unsupported lead-210 measurements to investigate soil erosion and sediment delivery in a small Zambian catchment. Geomorphology 52/3-4, 193-213.

Walling, D.E., He, Q. 1994: Rates of overbank sedimentation on the flood plains of several British rivers during the past 100 years. Variability in Stream Erosion and Sediment Transport (Proceedings of the Canberra Symposium, December 1994), IAHS Publ. no. 224, 203-210.

Walling, D.E., He, Q., 1998: The spatial variability of overbank sedimentation on river floodplains. Geomorphology 24/2-3, 209-223.

Walling, D.E., He, Q. 1999: Using fallout lead-210 measurements to estimate soil erosion on cultivated land. Soil Science Society of American Journal 63/5, 1404-1412.

Walling, D.E., Owens, P.N., Leeks, G.J.L. 1997: The characteristics of overbank deposits associated with a major flood event in the catchment of the River Ouse, Yorkshire, UK. CATENA 31/1-2, 53-75.

Wallinga, J., 2002: Optically stimulated luminescence dating of fluvial deposits: a review. Boreas 31, 303-322.

Wallinga, J., Hobo, N., Cunningham, A.C., Versendaal, A.J., Makaske, B., Middlekoop, H. 2010: Sedimentation rates on embanked floodplains determined through quartz optical dating. Quaternary Geochronology 5/2-3, 170-175.

Wang, C., Zheng, S., Wang, P., Hou, J. 2015: Interactions between vegetation, water flow and sediment transport: A review. Journal of Hydrodynamics 27/1, 24-37.

Warmink, J.J. 2007: Vegetation Density Measurements using Parallel Photography and Terrestrial Laser Scanning. Master thesis, Utrecht University, Utrecht, The Netherlands, p. 83.

Wasson, R.J., Mazari, R.K., Starr, B., Clifton, G. 1998: The recent history of erosion and sedimentation on the Southern Tablelands of southeastern Australia: sediment flux dominated by channel incision. Geomorphology 24/4, 291-308.

Waythomas, C.F. 1991: Magnetic susceptibility of fluvial sediment, Lower Fox River, Northeastern Illinois, and implications for determining sediment source area. U.S. Geological Survey, Water Resources Investigation Report, 91-4013.

Williams, G.P., Wolman, M.G. 1984: Downstream effects of dams on alluvial rivers. Professional Paper 1286, United States Geological Survey.

Wolman, M.G, Leopold, L.B. 1957: River floodplains: some observations on their formation. U.S. Geological Survey Professional Paper, 282-C, 87-107.

Wyżga, B. 1999: Estimating mean flow velocity in channel and floodplain areas and its use for explaining the pattern of overbank sedimentation and flood retention. Geomorphology 28, 281-297.

Wyżga, B. 2001: Impact of the channelization-induced incision of the Skawa and Wisłoka Rivers, Southern Poland, on the conditions of overbank sedimentation. Regulated Rivers /Research \& Management 17/1, 85-100.

$\mathrm{Xu}$, J. 2003: Sedimentation rates in the lower Yellow River over the past 2300 years as influenced by human activities and climate change. Hydrological Processes 17/16, 33593371.

Zinger, J.A., Rhoads, B.L., Best, J.L. 2011: Extreme sediment pulses generated by bend cutoffs along a large meandering river. Nature Geoscience 4, 675-678.

Zinger, J.A., Rhoads, B.L., Best, J.L., Johnson, K.K. 2013: Flow structure and channel morphodynamics of meander bend chute cutoffs: A case study of the Wabash River, USA. Journal of Geophysical Research: Earth Surface 118, 2468-2487.

Zwoliński, Z. 1992: Sedimentology and geomorphology of overbank flows on meandering river floodplains. Geomorphology 4, 367-379. 


\section{9. Összefoglaló}

\section{Elózmények, célkitüzések}

A 19. századi ármentesítési és mederszabályozási munkálatok jelentősen megbontották a folyók természetes egyensúlyi állapotát. A Tisza vízrendszerében az árvízvédelmi töltések kiépítése következtében a korábban 5-10 km széles ártérre kiöntő árvizek az 1-4 km szélességüre lecsökkentett hullámtéren vonulhatnak le. A folyó által szállított hordalékmennyiség a jóval szükebb hullámtéri területen halmozódik fel, ami a felszín fokozatos magasodását eredményezi. A hordalék intenzív felhalmozódása árvízvédelmi szempontból jelentős problémát okozhat, hiszen az árvizek levezetésére rendelkezésre álló hullámtéri térfogat csökken. A hullámtér vízszállító képességét jelentősen befolyásolhatják a vertikális és horizontális feltöltődés kitüntetett helyeinek számító folyóhátak és övzátonyok is. Ezek átmeneti formának tekinthetők a meder és a hullámtér között, és intenzív feltöltődésük révén jelentősen befolyásolhatják a hullámtérre kilépő árhullám áramlási viszonyait.

A hazai kutatások meglehetősen részletesen foglalkoztak a magyarországi folyók mentén zajló hosszú- és rövidtávú hullámtéri feltöltődés vizsgálatával, amelyhez különböző módszereket alkalmaztak. Ezek a kutatások azonban többnyire pontszerü méréseken alapultak, illetve csak egy-egy rövidebb szakaszon vizsgálták a feltöltődést, és ezeket az eredményeket általánosították hosszabb folyószakaszokra. Ráadásul leginkább a hordalék felhalmozódásának térbeli mintázatával foglalkoztak, és csupán néhány kutatás érintette a felhalmozódást befolyásoló tényezők vizsgálatát. Emellett a folyóhátak és övzátonyok hosszú távú fejlődéséről, a formálódásukat befolyásoló tényezőkről, illetve arról, hogy milyen mértékben tükrözik a vízrendszerben bekövetkezett változásokat csak kevés adat áll rendelkezésre, ugyanakkor ezen ismeretek alapvetően hozzájárulhatnak a folyórendszerek átalakulásának megértéséhez.

Kutatásom alapvető célja az árvízvédelmi töltések megépítése óta felhalmozódott hordalék mennyiségének meghatározása a teljes Alsó-Tisza mentén, azaz a feltöltődés mértékének megadása nem pontszerü mérési adatokon alapulva. Mivel a feltöltődés mértékét nagyobb területen értékelem, célom annak vizsgálata is, hogy a hordalék-felhalmozódást az adott folyószakaszon milyen tényezők befolyásolják. Mivel a feltöltődés kitüntetett helyei a folyóhátak és az övzátonyok, ezért ezen formák fejlődését kiemelten vizsgálom. A kutatás során a következő föbb célokat tüztem ki.

A hullámtér egészén felhalmozódott hordalék mennyiségének és az azt befolyásoló tényezöknek a vizsgálata:

- Mi jellemzi a hullámtér $90 \mathrm{~km}$ hosszú szakaszán a feltöltődés vastagságát és térfogatát? Milyen hatása van a hullámtér feltöltődésre a hullámtér-szélességének, a beömlő mellékfolyóknak és a növényzetnek?

- A felhalmozódott hordalék mennyivel csökkentette az árvizek levezetésére szolgáló hullámtéri térfogatot, és mely szakaszokon a legjelentősebb a hullámtér vízvezetőképességének csökkenése?

- A 18. század óta hogyan változott az Alsó-Tisza hullámterén a felszínborítás és a növényzeti érdesség? Az invazív gyalogakác milyen mértékben terjedt el az egyes felszínborítási kategóriákban, és jelenléte milyen mértékben növeli a hullámtéri növényzet sürüségét?

A folyóhátakon és az övzátonyokon történő hordalék felhalmozódást befolyásoló tényezök vizsgálata:

- A folyóhátak magasságát, szélességét és épülésük ütemét mely főbb tényezők határozzák meg?

- A kanyarulatok vándorlási típusa és üteme hogyan és milyen mértékben befolyásolja az egyes övzátonyok morfológiai jellemzőit (magasság és szélesség)?

- Az övzátony-sorokat alkotó tagok magasságának meder irányában történő változása és szélességük alapján milyen övzátony-fejlödési típusok különíthetők el? Ezeket milyen tényezők befolyásolják és milyen folyamatokra utalnak? 


\section{Anyag és módszer}

Kutatásomat az Alsó-Tisza menti hullámtéren végeztem Csongrád és szerb országhatár közötti szakaszon. A feltöltődés mértékének és az azt befolyásoló tényezők hatásának meghatározásához különböző módszereket alkalmaztam.

A 19. századi árvízvédelmi töltések kiépítése óta zajló feltöltődést a jelenlegi aktív hullámtér és a gátak mögötti mentett ártéri területek abszolút magasságkülönbsége alapján határoztam meg. Az aktív hullámtéri területekről rendelkezésemre állt egy nagy felbontású (0,5x0,5 m; vertikális pontosság: $\pm 10 \mathrm{~cm}), 2014$-ben készült LiDAR felvételezés alapján készült domborzatmodell. A töltések mögötti területek esetében az 1979-1985 között készült topográfiai térképezés alapján létrehozott, $5 \times 5 \mathrm{~m}$-es felbontású digitális domborzatmodellt használtam fel (vertikális pontossága $\pm 45 \mathrm{~cm}$ ).

A felhalmozódott hordalék vastagságát és térfogatát elöre meghatározott, a folyó középvonalára meröleges vonalakkal határolt, 1 km hosszú területegységekben számszerüsítettem a folyó jobb és bal partján egyaránt.

A hullámtér és a mentett ártéri területek közötti magasságkülönbség alapján kapott, a feltöltődés térfogatára vonatkozó adatok alapján kiszámítottam, hogy a hullámtér vízszállítóképessége mennyivel csökkent (\%) az adott területegységben.

A folyóhátak méreteit (magasság és szélesség) szintén a 2014-es LiDAR felvétel alapján elkészült DDM-en vizsgáltam. A formák legnagyobb relatív magasságát a mentett ártéri területek átlagmagasságához viszonyítva határoztam meg. Ugyanezen pontokban megmértem a folyóhátak szélességét is a felszínről készített keresztmetszet alapján. A folyóhát peremét a partél és azon pont között határoztam meg, ahol a folyóhát az ártérbe simul, azaz ahol a felszín lejtése $\leq 1^{\circ}$. Kiszámítottam a hordalék lerakódásának ütemét ( $\mathrm{mm} / \mathrm{e} v)$ is, amelyet a forma épülésének kezdete és 2014 (LiDAR felmérés) közötti időszakra számítottam ki a forma legnagyobb magassága alapján.

A folyóhátak anyagát szemcseösszetételi vizsgálatok céljából megmintáztuk, amely alapján következtetni lehet a hordalék-felhalmozódás körülményeinek térbeli és időbeli trendjére.

Az övzátonyokat is a LiDAR felmérés (2014) alapján elkészített DDM-en azonosítottam és ezen adatforrás alapján meghatároztam az egyes kanyarulatok övzátony-sorait alkotó tagok számát, illetve keresztmetszetek segítségével lemértem a formák magasságát és szélességét is. Az övzátonyok legnagyobb relatív magasságát a folyóhátakhoz hasonlóan a mentett ártéri területek átlagmagasságához viszonyítva határoztam meg, míg szélességét az adott formát két oldalról határoló mélyedés (sarlólapos) legmélyebb pontjai közötti távolságaként adtam meg.

A feltöltődést befolyásoló tényezők vizsgálatához az egyes területegységekben megmértem a hullámtér jobb és baloldali, illetve teljes átlagszélességét, továbbá a meder átlagos szélességét is meghatároztam a különböző időpontokban (1784, 1861, 1890, 1929, 1976, 2014). Ezen kívül megnéztem, hogy van-e az adott szakaszon partbiztosítás és azt mikor építették.

Az Alsó-Tisza vizsgált szakaszán lévő 39 kanyarulatnak lemértem a morfometriai paramétereit a 2014-es LiDAR-alapú DDM alapján. A kanyarulatoknak megmértem a görbületi sugarát, valamint az ív- és húrhosszát, illetve a sodorvonal parttól való távolságát is, amelyet az 1976. évi felmérés VO-szelvényei alapján határoztam meg, és amit a 2017-es mederfelmérés alapján pontosítottam. A kanyarulatok ív- és húrhosszának hányadosa alapján meghatároztam az egyes kanyarulatok fejlettségét is.

A kanyarulatvándorlás sebességét (m/év) a 18. század vége óta rendelkezésre álló katonai felmérések (1783, 1861) és vízrajzi térképek (1890, 1929 és 1976), továbbá a LiDAR felmérés (2014) alapján számítottam ki.

A mintaterület hosszútávú felszínborítás-változásának vizsgálatához az 18. század végétől rendelkezésre álló térképeket $(1784,1861,1881,1985)$ és egy GoogleEarth müholdfelvételt (2017) használtam fel. Mindegyik felmérés alapján 8 felszínborítási kategóriát határoztam meg. A felvételezések időpontjára kiszámítottam a hullámtér növényzeti érdességét (n) is: a 
szakirodalomban meghatározott átlagos érdességi értékeket (Chow 1959) súlyoztam az egyes időszakokban a felszínborítási kategóriák területi arányával.

A gyalogakác növényzetsürüség-növekedésben játszott szerepének meghatározására egy fénykép alapú módszert alkalmaztam (Warmink 2007), amellyel meghatározható egy adott térfogaton belül a növényzet által elfoglalt terület aránya, ezáltal sürüsége a folyásiránnyal szembeni felületen. Ezt a növényzetsürüség számítást elvégeztem a jelenlegi állapotokra (2017/2018 tele) 15 ponton Szegedtől északra. A fényképeket 3 felszínborítási kategóriában készítettem: ültetett erdőkben, ártéri erdőkben és olyan müvelés alól kivett szántókon, felhagyott réteken és legelőkön, ahol a gyalogakác erőteljes terjedésnek indult. A fényképeket téli időszakban készítettem, amikor a növényzeten nem volt levélzet. Ahhoz, hogy kiszámítsam, milyen mértékben járul hozzá a gyalogakác maga a növényzeti érdességéhez, az elkészített képekröl letörtöltem a gyalogakácot.

\section{Az eredmények összefoglalása}

\subsection{A hullámtér feltöltódésének jellemzöi és a folyamatot befolyásoló tényezök}

Az Alsó-Tisza vizsgált szakaszán átlagosan 1,2 m vastagságú hordalék halmozódott fel az árvízvédelmi töltések kiépítése óta, amely 90 millió $\mathrm{m}^{3}$ hordaléknak felel meg. A hordalék vastagsága és térfogata azonban eltér a hullámtér jobb és bal oldalán, illetve területegységenként is. A felhalmozódott hordalék átlagos vastagsága a hullámtér jobb és bal oldalán egyaránt $1,2 \mathrm{~m}$, területegységenként azonban 0,4-2,6 m között változik. Az üledék térfogata a jobb oldali hullámtéren átlagosan 0,35 millió $\mathrm{m}^{3}$, míg a bal oldalon ennek kétszerese, átlagosan 0,75 millió $\mathrm{m}^{3}$, területegységenként pedig 0,02-6,2 millió $\mathrm{m}^{3}$ között van.

A feltöltődés legfontosabb következménye a hullámtér vízszállító-képességének csökkenése, amely az árvízvédelmi töltések kiépítése óta átlagosan 22,6\%-kal romlott. A legnagyobb vízszállító-képesség csökkenéssel jellemezhető szakaszokon a csökkenés mértéke több, mint 40\%, tehát az árvizek levezetésére közel fele akkora hely áll rendelkezésre, mint a töltések kiépítését megelőzően. Ezek az árvizek szempontjából kritikusnak tekinthető pontok Csongrád, Mindszent-Mártély térségében, Algyőnél, illetve Szegedtől délre találhatók, ahol 1-7 km hosszú szakaszokat érintenek.

A hullámtér változó szélessége jelentősen meghatározza a felhalmozódott hordalék térfogatát $\left(\mathrm{R}^{2}=0,87\right)$. A szük hullámtéri szakaszokon $(<700 \mathrm{~m})$, a felhalmozódás térfogata legfeljebb 1,45 millió $\mathrm{m}^{3}$. A folyásirányban lefelé táguló, de még mindig szük szakaszokon (700$1000 \mathrm{~m}$ ) legfeljebb 1,5 millió $\mathrm{m}^{3}$ hordalék halmozódott fel. A tág szakaszokon $(>1000 \mathrm{~m}) \mathrm{az}$ előbbi két csoporthoz képest 4-szeres mennyiségü hordalék akkumulálódott (max: 6,14 millió $\mathrm{m}^{3}$ ), míg a folyásirányban szükülő, de még tág hullámtéri területegységekben a felhalmozódás maximális térfogata feleakkora $\left(3,4\right.$ millió $\left.\mathrm{m}^{3}\right)$, mint a tág szakaszok esetében, de még mindig közel kétszerese a szük hullámtéri szakaszokon vagy a táguló szakaszon mértnek. A felhalmozódott hordalék vastagsága azonban nem mutat egyértelmü kapcsolatot a hullámtér szélességével, amely a helyi befolyásoló tényezők fontosságát jelzi, illetve azt, hogy az adott helyen kialakuló mederélhez kötődő ártéri forma (folyóhát vagy övzátony) is alapvetően befolyásolhatja a feltöltődés vastagságát.

Az Alsó-Tiszába ömlő mellékfolyók (Hármas-Körös, Maros) eltérő hatást gyakorolnak a Tisza menti hullámtér feltöltődésére, amely összefüggésben van a két mellékfolyó eltérő esésével, hidrológiai tulajdonságaival és a lebegtetve szállított hordalék mennyiségével. A Hármas-Körös torkolata alatt 0,6-1,1 m-rel vékonyabb, térfogatát tekintve pedig feleannyi hordalék akkumulálódott, mint a torkolattól felvízi irányban. Ennek oka a Hármas-Körösön a torkolathoz közel megépített két duzzasztó miatt lecsökkent a hordalékhozam. Ez a torkolat alatti szakaszon a Tisza munkavégző-képességének növekedését eredményezi, amely a hordalékszállítás felé tolhatja el a szakasz hordalékegyensúlyát az akkumuláció irányából. Ez a hatás alvízi irányban a torkolattól számított $5 \mathrm{~km}$-es távolságig érvényesül. Ezt a folyóhátak szemcseösszetétele is alátámasztja, hiszen a torkolat alatti $5 \mathrm{~km}$ hosszú szakaszon belül a folyóhátak felső 5-10 cm mély 
rétegében nem fordult elő homokos hordalék, csupán iszap (átl. 69\%) és agyag (átl. 31\%). Ugyanakkor a Maros esetében 0,6 m-rel vastagabb felhalmozódás figyelhető meg a torkolat alatti szakaszokon, bár attól egy kissé távolabb, Szegedtöl közvetlenül délre indul meg a hordalék intenzívebb felhalmozódása. A torkolat és az intenzívebb feltöltődéssel jellemezhető szakasz között az akkumuláció mértékének csökkenését a rendkívül szük hullámtér okozza, amely a torkolat alatti szakaszon átlagosan mindössze $470 \mathrm{~m}$. A szük hullámtér és a Maros nagy esése miatt megnövekedő fajlagos munkavégző képesség eredményeképpen a hordalék felhalmozódása helyett annak elszállítása jellemző a torkolattól számított $3 \mathrm{~km}$-en belül. Ezt követően a hullámtér kitágul (átlagosan 750 m-re), így a vízáramlás kissé lelassul és megindul a hordalék intenzívebb akkumulációja, amihez a Maros többlet hordaléka is hozzájárul.

Az Alsó-Tisza felszínborítása jelentős változásokon ment keresztül a 18. század vége óta, és vele együtt a hullámtéri felszín növényzeti érdessége közel megötszöröződött. Az árvízvédelmi töltések kiépítése előtt a jelenlegi hullámtér területének 83\%-a állandó, vagy időszakos vízborítás alatt állt, míg a töltések kiépítése után arányuk hirtelen lecsökkent, és a mocsaras területeket kezdetben fokozatosan felváltották a rétek és legelők, amelyek később beerdősülésnek indultak. Az 1800-as évek végén a rétek és legelők a mintaterület 76\%-át alkották, amelyek felén ekkor már megjelent a fásszárú növényzet. Ezzel párhuzamosan a felszín növényzeti érdessége a kétszeresére nőtt ( $\mathrm{n}=0,023$-ról $\mathrm{n}=0,048-\mathrm{ra})$. Az 1900-as évek végén azonban az erdőtelepítések hatására a mintaterület legnagyobb részét (61\%) már erdők borították, amely a rétek és legelők csökkenését eredményezte. Ez a következő évtizedekben tovább folytatódott, így 2017-re az erdők kiterjedése 73\%-ra nőtt, a rétek és legelök aránya pedig 11\%-ra csökkent. Ezt a változást követte a növényzeti érdesség is, hiszen értéke a 2017. évi légifelvétel alapján meghatározott felszínborítás szerint $n=0,09$ volt. Terepi méréseim azonban jóval nagyobb növényzeti érdességet mutatnak $(n=0,11)$, amelynek oka a 20 . század közepén intenzív terjedésnek indult gyalogakác (Amorpha fruticosa) nagy arányú jelenléte.

Az invazív gyalogakác különböző mértékben fertőzte meg az egyes felszínborítási kategóriákat, legjelentősebb állományaik az ültetett nyarasokban és a parlagokon alakultak ki. A gyalogakác legkisebb mértékben a természetközeli ártéri erdőkben terjedt el, ahol átlagosan csupán 3\%-kal növeli a növényzetsürüséget. Ennek oka, hogy az idősebb fák árnyékoló hatása miatt a gyalogakác kevésbé tudja megfertőzni ezen erdőfoltok belsőbb területeit. Ennél nagyobb mértékben fertőzte meg az ültetett nyárerdőket, ahol a gyalogakác hatására a növényzet sürüsége átlagosan 23\%-kal növekedett, amely mértéke erdőfoltonként függ az aljnövényzet gondozásának mértékétől. A gyalogakác a legnagyobb mértékben a parlagon hagyott szántókon, réteken és legelökön terjedt el, ahol átlagosan 76\%-kal növeli a növényzetsürüséget, de ez egyes helyeken a $100 \%$-ot is elérheti.

A feltöltődés vastagságának és a növényzeti érdesség adatai alapján az $n=0,08$ érdesség egy küszöbértéket jelent a hordalék-felhalmozódás szempontjából. Eszerint a part menti növényzet sürüsödésével a hullámtérre kilépő víz sebessége egyre nagyobb mértékben mérséklődik, tehát a part menti növényzet egyre nagyobb mennyiségü hordalék felhalmozódását eredményezi. A felszínérdesség további növekedésével $(\mathrm{n}>0,08)$ azonban csökkenni kezd a feltöltödés vastagsága, ugyanis a partokon helyenként áthatolhatatlanul sủrü növényzet nő, ami árvizekkor szürőként vagy szivacsként viselkedhet és megakadályozza a hordalék továbbszállitását az ártér távolabbi területei felé.

\subsection{A hordalék felhalmozódását a part menti sávban befolyásoló tényezők vizsgálata}

A folyóhátak magasságát elsősorban a kanyarulatok görbületi sugara és a hullámtér szélessége határozza meg, de a partbiztosítások gyenge hatása is kimutatható. A kanyarulatok görbületi sugara és a hullámtér szélességének hatása azonban eltérő a különböző fejlettségü kanyarulatok mentén. Az ál- és fejletlen kanyarulatok esetén a görbületi sugár folyóhátak magasságára gyakorolt hatása gyengébb $\left(\mathrm{R}^{2}=0,16\right)$, amely kapcsolatban áll a nagy görbületi sugárból adódó kisebb centrifugális erővel, illetve az ezen kanyarulatok mentén jellemző szük hullámtéri szakaszokkal $(<200 \mathrm{~m})$, amely megakadályozza a görbületi sugár hatásának 
érvényesülését. Így az ál- és fejletlen kanyarulati csoporton belül a formák magasságát elsősorban a hullámtér szélessége határozza meg.

A fejlett és érett kanyarulatok mentén a görbületi sugár már erőteljesen befolyásolja a folyóhátak magasságát $\left(\mathrm{R}^{2}=0,86\right)$. Ez a kanyarulatok közel felénél tapasztalható, ahol a hullámtér elég széles ( $\geq 200 \mathrm{~m}$ ) ahhoz, hogy a görbületi sugár hatása érvényesülni tudjon. A kanyarulatok másik fele mentén, ahol a hullámtér szük, a hullámtér-szélesség határozza meg a folyóhátak magasságát. A görbületi sugár és a hullámtér-szélesség mellett a partbiztosítások is meghatározzák, habár csupán kis mértékben a formák magasságát. A partbiztosított szakaszokon 0,2-0,3 m-rel magasabb folyóhátak fejlödtek, mint a szabadon fejlödő kanyarulatok mentén.

A folyóhátak szélessége mind az ál- és fejletlen, mind pedig a fejlett és érett kanyarulatok mentén a hullámtér szélességével mutat kapcsolatot $\left(\mathrm{R}^{2}=0,65\right)$. A fejlett és érett kanyarulatok mentén azonban, ahol a széles $(\geq 200 \mathrm{~m}$ ) hullámtéri szakaszok lehetővé teszik, a kanyarulatok görbületi sugara is meghatározó $\left(\mathrm{R}^{2}=0,5\right)$, hiszen ezek a kanyarulatok rendszerint kis görbületi sugárral rendelkeznek, így az ebböl adódó nagy centrifugális erő lehetővé teszi, hogy a hordalék nagyobb távolságra eljusson a hullámtéren.

A folyóhátak épülésének üteme mindkét kanyarulati csoport esetében szoros kapcsolatot mutat a formák korával, így az idősebb formák lassabban, addig a fiatalabb formák gyorsan fejlődnek. Eredményeim szerint a legidősebb (> 180 év) folyóhátak átlagosan 21-22 mm/év ütemben épülnek, míg a legfiatalabb (legfeljebb 40 éves) formák felszínén átlagosan 83-115 $\mathrm{mm} /$ év ütemmel zajlik az akkumuláció. Mindez a hordalék-felhalmozódás ütemének gyorsulását mutatja, amelynek legföbb oka az egyre sürübbé váló part menti növényzet, a meder szükülése és a partélek magasodása miatt az árhullámok munkavégző képességének növekedése lehet. A folyóhátak felszínén a hordalék-felhalmozódás üteme kis mértékben mérséklödhet a kanyarulat külső ívéhez közel helyezkedő sodorvonal miatt. Úgy vélem, hogy árvizekkor a sodorvonal közelsége a víz nagyobb munkavégző-képességét eredményezi, amely megakadályozza, hogy nagyobb mennyiségü hordalék akkumulálódjon a szük part menti sávban, illetve a folyóhátak anyaga erodálódhat is, amely a formák átlagos épülési sebességének csökkenését eredményezi.

Az Alsó-Tisza mentén, a belső íven fejlődő övzátonyok magassági és szélességi viszonyai az elforduló kanyarulatok esetén a görbületi sugárral arányosak. Az Alsó-Tisza mentén vizsgált kanyarulatoknak fejlődésük módja alapján három típusa alakult ki: a kanyarulatok 70\%-a megnyúló, amelyek 750 m-nél nagyobb görbületi sugárral rendelkeznek, 23\%-a 750 m-nél kisebb görbületi sugárral rendelkező elforduló típusú, míg áthelyeződő vándorlást csupán egy kanyarulat mutat. Eredményeim szerint az elforduló típusú kanyarulatok mentén a legkisebb görbületi sugárral rendelkezők belső ívén 1,6 m-rel magasabb és 20 m-rel szélesebb övzátonyok alakultak ki, mint a megnyúló típusba tartozó kanyarulatok mentén.

A partelmozdulás ütemének hatása a meder szélességének változásán keresztül befolyásolja az övzátonyok szélességét, míg az övzátonyok magasságának változása összefügg a kanyarulatok külső ívén épített partbiztosítások miatt lelassult partelmozdulással. Az 1890-as felmérés óta az Alsó-Tisza medrének átlagos szélessége 17,2\%-kal csökkent (192 m-ről 159 m-re), amellyel együtt az övzátonyok átlagos szélessége is lecsökkent 68 m-ről 19 m-re. Az 1930-as és 1960-as évek között zajló intenzív partbiztosítás-építések miatt a partelmozdulás üteme eröteljesen lelassult, számos szakaszon meg is állt, hiszen míg az 1890 és 1929 közötti időszakban a külső ív elmozdulása átlagosan $0,5 \mathrm{~m} / \mathrm{év}$, a belső ívé pedig $1,1 \mathrm{~m} / \mathrm{e} v$ volt, addig ez a 2014. évi felmérés idejére $0 \mathrm{~m} /$ év -re lassult. Ennek hatására megállt az övzátonyok oldalirányú épülése, amelyet felváltott a hordalék vertikális felhalmozódása, amelynek eredményeként a kanyarulatok 70\%ánál megfigyelhető az övzátony-sorokat alkotó legutolsó övzátony-tag magasságának jelentős megemelkedése, amely a 2,3-3,4 m-t is elérheti.

Az övzátony-sorok utolsó tagjának megemelkedése miatt egyre nagyobb visszatérési idejü árvizek képesek csak az aktív övzátony magasítására. Míg korábban az övzátonyokat 1,2-1,8 évente visszatérö árvizek is elöntötték, napjainkban az aktív övzátonyt már csak a 2-4,8 évente visszatérö árvizek öntik el és építik tovább. 
Az Alsó-Tisza mentén az egyes kanyarulatokban kialakult övzátony-soroknak az ezeket alkotó tagok magasságának meder irányában történő változása alapján három típusát különböztettem meg: a meder irányában alacsonyodó, magasodó és változatlan magasságú övzátony-sorokat. Ezek a típusok összefüggnek a meder változásaival (pl. bevágódás), a kanyarulatvándorlás sebességében, és/vagy a fenék- és lebegtetett hordalékhozamban bekövetkezett változásokkal. A meder felé alacsonyodó övzátonyok utalhatnak (i) a meder bevágódására, hiszen ezt követve az övzátonyoknak alacsonyodniuk kell, (ii) a kanyarulatvándorlás sebességének növekedésére, tehát változatlan hordalékmennyiség mellett a formák épülésére egyre kevesebb idő állrendelkezésre, illetve (iii) az övzátonyt felépítő hordalék hozamának csökkenésére is, hiszen ebben az esetben változatlan partelmozdulást feltételezve az övzátonyok felszínén egyre kevesebb hordalék halmozódhat fel, így magasságuk csökken.

A meder irányában magasodó övzátonyok utalhatnak (i) a kanyarulatvándorlás ütemének csökkenésére, hiszen változatlan hordalékhozamot feltételezve egyre hosszabb idő áll rendelkezésre a formák épülésére, így egyre magasabbá válnak, (ii) az övzátonyt felépítő fenék-és lebegtetett hordalék hozamának növekedésére, mivel ha a forma kialakulásához rendelkezésre álló idő változatlan, a forma felszínén egyre nagyobb mennyiségü hordalék rakódik le, ami az övzátonyok egyre magasabbá válását eredményezi.

Mivel az alacsonyodó, magasodó és változatlan magasságú övzátony-sorok egymás szomszédságában fordulnak elő, a hordalékhozam általános változása az Alsó-Tiszán nem lehet kialakulásuk oka, hiszen az a formák magasságának változását egységesen eredményezné. Tehát az övzátony-fejlődési típusok létrejötte helyi befolyásoló tényezők szerepére hívja fel a figyelmet. Véleményem szerint az övzátony-fejlődési típusok létrejöttére és térbeli elhelyezkedésére jelentős hatással van a mederanyag kötöttsége, illetve az, hogy a nyugati oldalon az árvízvédelmi töltés jóval közelebb fut a mederhez, mint a folyó keleti oldalán, így a partbiztosítások is elsősorban a nyugati oldalon helyezkednek el. Ennek eredményeképpen az alacsonyodó övzátonyok-sorok többsége a hullámtér baloldalán, míg a magasodó övzátonyok a hullámtér jobb oldalán találhatók. 


\section{Summary}

\section{Introduction, aims}

The nineteenth-century river regulation works and artificial levee constructions disrupted significantly the natural equilibrium of alluvial rivers. As a result of levee constructions, the original 5-10 km wide floodplain has been reduced to 1-4 km, thus in the Tisza river floods can occur only in this narrow floodplain. The amount of sediment transported by the river accumulates in this much narrower floodplain, which results in the gradual rising of the floodplain surface. Intensive overbank sedimentation can be a major problem from the point of view of flood protection, since as a result of sedimentation processes; the floodplain area available for flood conveyance is reduced. Flood conveyance is also affected by natural levees and point-bars, which are the most characteristic depositional features of vertical and horizontal sedimentation. These can be considered as transitory forms between the channel and the floodplain, and through their intensive sedimentation, these forms significantly influence the flow conditions in the floodplain.

In Hungary many detailed research have been conducted on the long and short-term aggradation of the floodplains of Hungarian rivers, using different methods. These researches, however, were based on point measurements, or investigated overbank sedimentation in shorter river section, then generalized these result on longer river reaches. Moreover, the spatial pattern of sedimentation has been the focus of these studies, and only a few have studied the influencing factors of overbank sedimentation processes. Besides, there is little data available on the longterm development of natural levees and point-bars, on the factors influencing their formation, and on the rate that they reflect the changes in the river system. However, the knowledge of these data could contribute significantly to the understanding of changes in river systems.

The primary aim of this research is to determine the amount of sediment accumulated on the floodplain of the Lower Tisza River since the artificial levee constructions, i.e. to determine the rate of overbank sedimentation based on non-point measurements. Since the rate of sedimentation is estimated in a longer floodplain section, my aim is to investigate the factors affecting the process of overbank sedimentation in the Lower Tisza River as well. Since natural levees and point-bars are the most characteristic features of the floodplain, thus the investigation of the development of these forms is of high priority in this dissertation. During the research the following aims have been set.

Estimation of the amount of sediment accumulated throughout the floodplain and its influencing factors:

- What characterizes the thickness and volume of accumulated sediment in the analyzed 90km-long floodplain section? How floodplain width, tributaries and vegetation affect overbank sedimentation?

- To what extent has the accumulated sediment reduced the flood conveyance capacity of the floodplain, and in which floodplain sections this reduction is the most significant?

- How the land-cover and vegetation roughness of the floodplain of the Lower Tisza River have been changed since the eighteenth century? To what extent has the invasive Amorpha fruticosa has invaded the different land-cover categories, and to what extent has the presence of this species increased the vegetation roughness of the floodplain surface?

Investigation of factors influencing the accumulation of sediments on natural levees and pointbars:

- Which main factors determine the height, width, and rate of development of natural levees?

- How and to what extent do the type and rate of meander migration affect the morphological characteristics (height and width) of each point-bar?

- What types of point-bar development can be distinguished based on the changes in pointbar height in each point-bar complex in the direction of the channel? What are the primary factors influencing the formation of these types and what processes do they refer to? 


\section{Material and methods}

The study area of this research is the Lower Tisza River between Csongrád and the Serbian border. Different methods were used to determine the rate of overbank sedimentation and the effects if the influencing factors.

The rate of overbank sedimentation since the nineteenth-century artificial levee constructions was determined based on the height difference between the active floodplain and the flood-protected areas. On the active floodplain areas a high-resolution DTM $(0.5 \times 0.5 \mathrm{~m}$, vertical accuracy: $\pm 10 \mathrm{~cm}$ ) was used based on a 2014 LiDAR survey, while on the flood-protected areas a $5 \times 5$ m DTM was used which was created based on a 1979-1985 topographic mapping (vertical accuracy: $\pm 45 \mathrm{~cm})$.

The thickness and volume of the accumulated sediment were determined on both the right and left bank of the river, in 1-km-long floodplain units bordered by lines perpendicular to the centreline of the channel.

The volume of sediment was determined also based on the height difference between the floodplain and the flood-protected areas, and these values were used to calculate the rate of reduction in flood conveyance capacity $(\%)$ in each floodplain unit.

Dimensions of natural levees (height and width) were determined also based on the DTM created from the 2014 LiDAR survey. The maximum height of the forms was determined relative to the average height of the flood-protected areas. At the same points, the width of the natural levees was also measured based on floodplain cross-sections. The edge of the forms was determined between the river bank and the point where the levee merges into the floodplain, i.e. where the slope of the surface is less than $1^{\circ}$. The rate of sediment accumulation $(\mathrm{mm} / \mathrm{y})$ was also determined, which was calculated for the period between the beginning of the formation of the natural levees and 2014 (LiDAR survey) based on the maximum height of the forms.

Natural levees were sampled to study grain composition, which can be used to infer spatial and temporal changes in the conditions of sediment accumulation.

Point-bars were identified based on the DTM created from the 2014 LiDAR survey, then the number of point-bars forming each point-bar complex was determined based on crosssections, besides the height and width of the forms were measured as well. Similarly to natural levees, the maximum height of the point-bars was determined relative to the average height of the flood protected areas, while their width was defined as the distance between the deepest points of the swales bordering the point-bars on two sides.

To analyse the impact of different factors on overbank sedimentation, average, right and left-side floodplain width, and average channel width were measured in different years (1784, $1861,1890,1929,1976,2014)$ based on channel, military, and topographic surveys. Besides the presence of revetments and their year of construction were also checked.

In the Lower Tisza River, the morphometric parameters of 39 bends were measured based on the 2014 LiDAR survey. Radius of curvature, length of arch, length of chord of meanders, and the distance of thalweg from the riverbanks were also measured based on the 1976 channel mapping, and these data were specified based on a 2017 mapping. The state of development of meanders was also determined based on the ratio of arch and chord-length of the bends.

Rate of meander development $(\mathrm{m} / \mathrm{y})$ was calculated based on military surveys (1783 and 1861), hydrographic maps (1890, 1929 and 1976), and 2014 LiDAR survey.

To study the long-term changes in floodplain land-cover, different mappings $(1784,1861$, 1881, and 1985) available from the end of the eighteenth century, and a 2017 GoogleEarth image were used. For each year the vegetation roughness (n) of the floodplain was also calculated: the mean roughness values determined in the literature (Chow 1959) were weighted by the area of the land-cover categories.

To determine the role of Amorpha fruticosa in decreasing vegetation density in the floodplain, a photograph based method was used, which is suitable to calculate the area occupied by vegetation in a given volume, thus its density on a surface in downstream direction. The 
calculation of vegetation density was carried out for current conditions (winter of 2017/2018) in 15 plots, north of Szeged. The photographs were taken in 3 woody land-cover categories: in poplar plantations, in riparian forests, and in abandoned arable lands, meadows and pastures where $A$. fruticosa has started to spread aggressively. The photographs were taken in winter when there was no foliage on the vegetation. In order to calculate the contribution of $A$. fruticosa to vegetation roughness, it was erased from each image.

\section{Results}

\subsection{Characteristics of overbank sedimentation and its influencing factors}

Since the artificial levee construction, in the studied floodplain section of the Lower Tisza River an average of $1.2 \mathrm{~m}$ thick sediment layer has accumulated, which corresponds to 90 million $\mathrm{m}^{3}$ of sediment. The thickness and volume of deposited sediment, however, vary on the right and left side of the floodplain, and also in each floodplain unit. The average thickness of sediment is $1.2 \mathrm{~m}$ both on the right and left side of the floodplain; however it varies between 0.4-2.6 m. The average volume of sediment is 0.35 million $\mathrm{m}^{3}$ on the right side of the floodplain, while on the left side twice as much $\left(0.75\right.$ million $\left.\mathrm{m}^{3}\right)$ sediment has accumulated. The volume of sediment varies between 0.02-6.2 million $\mathrm{m}^{3}$ by floodplain units.

The most important result of overbank sedimentation is the gradual reduction in the flood conveyance capacity of the floodplain, which has decreased by $22.6 \%$ on average since the artificial levee constructions. In floodplain sections characterized by the greatest loss of flood conveyance capacity, the rate of reduction is more than $40 \%$, i.e. half as much space is available for flood conveyance than before levee constructions. These critical points are located near Csongrád. Mindszent-Mártély, Algyő, and south of Szeged, where the greatest reduction in flood conveyance affects 1-7-km-long floodplain reaches.

The varying width of the floodplain determines significantly the volume of accumulated sediment $\left(\mathrm{R}^{2}=0.87\right)$. In narrow $(<700 \mathrm{~m})$ floodplain sections, the maximum volume of sediment is 1.45 million $\mathrm{m}^{3}$. A maximum of 1.5 million $\mathrm{m}^{3}$ of sediment has been accumulated in widening but still narrow floodplain sections (700-1000 m). In broad sections (> $1000 \mathrm{~m})$ 4-fold amount of sediment (max: 6.14 million $\mathrm{m}^{3}$ ) has been accumulated than in the former two groups, while in narrowing but still wide floodplain units the maximum volume of sediment is half as much (3.4 million $\mathrm{m}^{3}$ ) than in the broadest sections, but still nearly twice as much than in the narrowest and widening sections. The thickness of accumulated sediment, however, does not show a clear relationship with floodplain width, indicating the importance of local influencing factors, and that forms (natural levees and point-bars) associated with the river bank may have a significant influence on sediment thickness.

Tributaries (Hármas-Körös and Maros River) flowing into the Lower Tisza River have different impacts on overbank sedimentation in the Tisza River floodplain, which is related to the varying slope, hydrological characteristics, and the amount of transported suspended sediment of the two tributaries. Downstream of the mouth of the Hármas-Körös River, 0.6-1.1 m thinner and half the volume of sediment has accumulated in the floodplain than in the upstream sections. This is due to the two dams built in the Hármas-Körös River close to its mouth, which have reduced the sediment yield of the river. Decreased sediment yield results in the increased stream power of the Tisza River, which may shift the sediment balance from accumulation to transportation. This effect of the Hármas-Körös River occurs up to $5 \mathrm{~km}$ from the river mouth. Besides, this effect is also reflected in the grain size composition of natural levees along the Tisza River, since no sandy sediment occurred in the upper 5-10 cm deep layer of the natural levees, only silt $(69 \%$ on average) and clay ( $31 \%$ on average) were found. In contrast, a $0.6 \mathrm{~m}$ thicker sediment layer has deposited downstream of the river mouth of the Maros River, and more intensive sedimentation occurs slightly further from the river mouth, south of Szeged. The decrease in overbank sedimentation in the floodplain reach between the river mouth of the Maros River and the section 
with intensive overbank accumulation is caused by the narrow floodplain, which is merely $470 \mathrm{~m}$ wide downstream of the river mouth.

This narrow floodplain and the great slope of the Maros River results in increased stream power, thus instead of accumulation sediment transportation occurs in a 3-km-long section. The floodplain widens in downstream direction (up to $750 \mathrm{~m}$ ), causing the water flow to slow down on the floodplain and resulting in more intensive overbank sedimentation, which is contributed by the greatest sediment yield of the Maros River.

Land-cover of the floodplain of the Lower Tisza River has changed significantly since the end of the eighteenth century, and simultaneously the vegetation roughness of the surface has increased nearly fivefold. Before the artificial levee constructions, $83 \%$ of the present-day floodplain area was periodically or permanently covered by water. After the construction works the area of wetlands suddenly decreased, and they were gradually replaced by meadows and pastures, on which later trees started to grow. At the end of the 1800s, meadows and pastures occupied $76 \%$ of the study area, and nearly half of them were covered by sparse trees and bushes. Simultaneously, vegetation roughness doubled (from $n=0.023$ to $n=0.048$ ). At the end of the 1900 s, however, most of the study area (61\%) was covered by forests as a result of intensive forestation, thus the area of meadows and pastures significantly decreased. This process continued in the subsequent decades, and as a result the area of forest increased up to $73 \%$, and the area of meadows and pastures decreased to $11 \%$ by 2017 . Vegetation roughness followed these landcover changes, as its value was $n=0.09$ estimated based on the 2017 GoogleEarth image. Field measurements, however, suggest a much greater vegetation roughness $(n=0.11)$ due to the presence of the invasive Amorpha fruticosa, which started to spread aggressively in the midtwentieth century.

The invasive Amorpha fruticosa invaded the different land-cover categories by varying degrees, with the most significant populations occurring in poplar plantations and fallow lands. $A$. fruticosa has invaded riparian forests to the lowest degree, where it increases vegetation density only by $3 \%$. It is due to the fact that because of the shading effect of older trees, A. fruticosa is less able to invade the inner areas of riparian forest patches. In poplar plantations vegetation density is increased by $23 \%$ on average due to the presence of $A$. fruticosa, and the degree of invasion is dependent on the degree of undergrowth tending. A. fruticosa has invaded fallow lands (arable lands, meadows and pastures) to the highest degree, since it contributes to vegetation density by $76 \%$ on average, but at some places it can reach $100 \%$.

Based on the relationship between the thickness of accumulated sediment and vegetation roughness the $n=0.08$ roughness represents as a threshold value for overbank sedimentation. As riparian vegetation becomes denser, the velocity of overbank flow increasingly decelerates, thus a greater amount of sediment accumulates near the river bank. As vegetation roughness increases $(n>0.08)$, however, the thickness of deposited sediment begins to decrease, since at some sections of the bankline a very dense, impenetrable shrubbery grows, which acts as a filter or sponge against floods and prevents sediment to be transported to distal areas of the floodplain.

\subsection{Factors influencing overbank sedimentation in the riparian zone}

The height of natural levees is determined by the radius of curvature of meanders and floodplain width, although the slight effect of revetments can also be demonstrated. The effects of radius of curvature and floodplain width vary by stages of meander development. Along pseudo and undeveloped meanders, the impact of radius of curvature on the height of the natural levees is slighter $\left(\mathrm{R}^{2}=0.16\right)$, which is related to the smaller centrifugal force resulting from the great curvature, and to the narrow floodplain sections $(<200 \mathrm{~m})$ along these meanders, which prevents the radius of curvature to be effective. Thus, along pseudo and undeveloped meanders the height of natural levees is primarily determined by floodplain width.

Along developed and mature meanders the height of natural levees is strongly affected by the radius of curvature $\left(\mathrm{R}^{2}=0.86\right)$. This occurs along nearly half of the meanders, where the floodplain is broad enough $(\geq 200 \mathrm{~m}$ ) to allow the effect of the radius of curvature to prevail. Along the other 
half of the meanders, where the floodplain is narrow, the height of natural levees is affected by floodplain width. The height of the forms is also affected by revetment, although to a slighter degree. Along floodplain sections with revetments 0.2-0.3 $\mathrm{m}$ higher natural levees have formed than along freely developing meanders.

The width of natural levees is related to floodplain width $\left(\mathrm{R}^{2}=0.65\right)$ along both pseudoundeveloped meanders and developed-mature meanders. However, along the former group, where the floodplain is broad enough $(\geq 200 \mathrm{~m})$ the effect of radius of curvature also prevails $\left(\mathrm{R}^{2}=0.5\right)$, since these meanders have small radius of curvature, thus the centrifugal force allows the sediment to be transported to distal areas of the floodplain.

The rate of sediment accumulation on the surface of natural levees is closely related to the age of the forms, thus older natural levees develop slower while younger ones develop faster. According to my results, older natural levees (> 180 years old) develop at an average rate of 21-22 $\mathrm{mm} / \mathrm{y}$, while on the surface of the youngest forms (max. 40 years old) sediment accumulation has an average rate of 83-115 mm/y. This difference suggests an acceleration in sediment accumulation, which is a primarily due to the increasing density of riparian vegetation, channel narrowing, and increased stream power of floods. The rate of sediment accumulation may be slightly reduced by thalweg being closer to the outer bankline. During floods, in my opinion, the proximity of the thalweg results in a greater stream power, and this prevents a greater amount of sediment to accumulate along the bankline. Besides, natural levees can be also eroded away, which results in a decrease of average rate of sediment accumulation on the surface of the forms.

The height and width of point-bars is in direct proportion to the radius of curvature in the case of rotating meanders. Three groups of the studied meanders along the Lower Tisza River can be distinguished: $70 \%$ of the meanders are expanding, and have a radius of curvature of greater than $750 \mathrm{~m} ; 23 \%$ of the meanders are rotating, and a have radius of curvature of smaller than 750 $\mathrm{m}$; while only one meander is characterized by transition. According to my results, $1.6 \mathrm{~m}$ higher and $20 \mathrm{~m}$ wider point-bars were formed along rotating meanders with the smallest radius of curvature than along expanding meanders.

The width of point-bars is affected by the rate of meander migration through its impact on channel width, while the height of point-bars is related to decelerating meander migration due to revetments built on the outer banks. Since the 1890 channel survey, the average channel width of the Lower Tisza River has decreased by $17.2 \%$ (from $192 \mathrm{~m}$ to $159 \mathrm{~m}$ ), and simultaneously the average width of the point-bars has decreased from $68 \mathrm{~m}$ to $19 \mathrm{~m}$. Due to the intensive revetment constructions between 1930 and 1960, the rate of meander migration decreased significantly, and at many channel sections it ceased, as while the average rate of migration of the outer bank was $0.5 \mathrm{~m} / \mathrm{y}$ and of the inner bank was $1.1 \mathrm{~m} / \mathrm{y}$ between 1890 and 1929 , it decreased to $0 \mathrm{~m} / \mathrm{y}$ by 2014. As a result the lateral formation of point-bars ceased, which has been replaced by the vertical accumulation of sediment resulting in a significant increase in the height of the youngest point-bars. This increase can reach 2.3-3.4 m and is observed along 70\% of the studied meanders.

Due to the increasing height of point-bars, sediment can accumulate on the surface of the forms during only floods with increasing return period. While earlier the point-bars were covered by floods with a return period of 1.2-1.8 years, nowadays the forms are only flooded and built by floods with a return period of 2-4.8 years.

Along the Lower Tisza River, three main types of point-bar development can be distinguished based on the height changes of point-bars towards the channel: descending, ascending, and constant. These types are related to changes in the channel (e.g. incision), the rate of bend migration, and/or bedload and suspended sediment yield. The decrease in the height of point-bars in a given point-bar series may indicate (i) channel incision, as the point-bars have to decrease if the conditions and the time available for development do not change; (ii) accelerating meander migration, as in this case there is less time available for the formation of the point-bars, and (iii), it may indicate a decrease in sediment yield, as it would take a longer time for the pointbars to form, while no more time is available with the same rate of erosion on the concave bank. 
The increase in the height of point-bars may indicate (i) decrease in the rate of meander migration, as more time is available for the formation of the point-bars; thus they became increasingly higher. Higher point-bars could also indicate (ii) an increase in bedload and suspended sediment yield, as, if the time available for point-bar formation is constant; more sediment accumulates on the surface of the point-bars, significantly increasing their height.

As descending, ascending, and constant point-bars occur adjacent to each other, the general variation in sediment yield of the Lower Tisza River cannot be the cause of their formation, since it would result in uniform changes in the height of point-bars. Thus, different types of point-bar development draw the attention to the influence of local influencing factors. 


\section{Függelék}

Jobb oldali hullámtéri területegységek főbb jellemzői

\begin{tabular}{|c|c|c|c|c|c|}
\hline $\begin{array}{l}\text { Terület- } \\
\text { egység } \\
\text { száma }\end{array}$ & $\begin{array}{c}\text { Terület } \\
\left(\mathbf{m}^{2}\right)\end{array}$ & $\begin{array}{c}\text { Hordalék } \\
\text { vastagsága } \\
(\mathbf{m})\end{array}$ & $\begin{array}{c}\text { Hordalék } \\
\text { térfogata } \\
\left(\text { millió } \mathbf{m}^{3}\right)\end{array}$ & $\begin{array}{c}\text { Vízszállító- } \\
\text { képesség } \\
\text { csökkenése } \\
(\%)\end{array}$ & $\begin{array}{l}\text { Növényzeti } \\
\text { érdesség } \\
\text { 2017-ben (n) }\end{array}$ \\
\hline 1 & 2700000 & 1,2 & 3,13 & 23 & 0,12 \\
\hline 2 & 2060000 & 0,9 & 1,90 & 18 & 0,13 \\
\hline 3 & 250000 & 0,7 & 0,17 & 13 & 0,12 \\
\hline 4 & 50000 & 0,4 & 0,02 & 9 & 0,13 \\
\hline 5 & 400000 & 1,4 & 0,55 & 27 & 0,13 \\
\hline 6 & 20000 & 1,5 & 0,03 & 30 & 0,13 \\
\hline 7 & 130000 & 1,8 & 0,23 & 36 & 0,13 \\
\hline 8 & 260000 & 1,4 & 0,35 & 27 & 0,12 \\
\hline 9 & 490000 & 1,6 & 0,77 & 31 & 0,12 \\
\hline 10 & 210000 & 1,2 & 0,24 & 23 & 0,10 \\
\hline 11 & 30000 & 2,2 & 0,07 & 45 & 0,07 \\
\hline 12 & 10000 & 1,8 & 0,02 & 37 & 0,04 \\
\hline 13 & 110000 & 1,5 & 0,17 & 30 & 0,02 \\
\hline 14 & 210000 & 1,1 & 0,24 & 22 & 0,06 \\
\hline 15 & 170000 & 0,8 & 0,13 & 16 & 0,12 \\
\hline 16 & 100000 & 0,7 & 0,07 & 15 & 0,13 \\
\hline 17 & 100000 & 0,4 & 0,04 & 7 & 0,12 \\
\hline 18 & 110000 & 1,1 & 0,12 & 22 & 0,13 \\
\hline 19 & 150000 & 1,5 & 0,22 & 29 & 0,09 \\
\hline 20 & 370000 & 1,5 & 0,54 & 29 & 0,11 \\
\hline 21 & 140000 & 1,3 & 0,19 & 27 & 0,09 \\
\hline 22 & 30000 & 1,8 & 0,06 & 37 & 0,12 \\
\hline 23 & 90000 & 2,4 & 0,21 & 48 & 0,12 \\
\hline 24 & 160000 & 1,2 & 0,20 & 25 & 0,12 \\
\hline 25 & 690000 & 1,7 & 1,19 & 34 & 0,11 \\
\hline 26 & 820000 & 1,3 & 1,04 & 25 & 0,12 \\
\hline 27 & 1240000 & 0,8 & 0,94 & 15 & 0,12 \\
\hline 28 & 780000 & 0,9 & 0,73 & 19 & 0,11 \\
\hline 29 & 950000 & 1,4 & 1,36 & 29 & 0,13 \\
\hline 30 & 600000 & 1,4 & 0,86 & 29 & 0,12 \\
\hline 31 & 410000 & 0,9 & 0,39 & 19 & 0,13 \\
\hline 32 & 100000 & 1,2 & 0,12 & 24 & 0,12 \\
\hline 33 & 310000 & 0,8 & 0,25 & 16 & 0,11 \\
\hline 34 & 270000 & 0,7 & 0,18 & 13 & 0,12 \\
\hline 35 & 250000 & 1,7 & 0,42 & 34 & 0,13 \\
\hline 36 & 470000 & 0,9 & 0,40 & 17 & 0,13 \\
\hline 37 & 560000 & 2,6 & 1,44 & 52 & 0,12 \\
\hline 38 & 200000 & 0,6 & 0,13 & 13 & 0,07 \\
\hline 39 & 30000 & 2,2 & 0,07 & 43 & 0,13 \\
\hline 40 & 40000 & 2,1 & 0,08 & 41 & 0,13 \\
\hline 41 & 220000 & 1,3 & 0,29 & 26 & 0,12 \\
\hline 42 & 340000 & 1,0 & 0,32 & 19 & 0,11 \\
\hline
\end{tabular}




\begin{tabular}{|c|c|c|c|c|c|}
\hline 43 & 360000 & 1,7 & 0,63 & 35 & 0,12 \\
\hline 44 & 200000 & 1,0 & 0,20 & 20 & 0,12 \\
\hline 45 & 120000 & 1,5 & 0,18 & 31 & 0,12 \\
\hline 46 & 160000 & 1,4 & 0,22 & 27 & 0,13 \\
\hline 47 & 240000 & 1,9 & 0,45 & 37 & 0,13 \\
\hline 48 & 200000 & 0,6 & 0,11 & 11 & 0,13 \\
\hline 49 & 270000 & 0,9 & 0,23 & 17 & 0,12 \\
\hline 50 & 280000 & 1,0 & 0,28 & 20 & 0,11 \\
\hline 51 & 190000 & 1,3 & 0,24 & 25 & 0,11 \\
\hline 52 & 220000 & 1,4 & 0,31 & 28 & 0,13 \\
\hline 53 & 170000 & 0,6 & 0,09 & 11 & 0,13 \\
\hline 54 & 870000 & 1,2 & 1,06 & 24 & 0,12 \\
\hline 55 & 750000 & 0,4 & 0,30 & 8 & 0,13 \\
\hline 56 & 460000 & 0,9 & 0,42 & 18 & 0,12 \\
\hline 57 & 230000 & 1,4 & 0,31 & 27 & 0,12 \\
\hline 58 & 180000 & 1,18 & 0,21 & 24 & 0,13 \\
\hline 59 & 130000 & 1,3 & 0,17 & 26 & 0,12 \\
\hline 60 & 190000 & 1,6 & 0,30 & 32 & 0,12 \\
\hline 61 & 460000 & 0,6 & 0,25 & 11 & 0,12 \\
\hline 62 & 260000 & 1,5 & 0,40 & 31 & 0,12 \\
\hline 63 & 80000 & 2,0 & 0,16 & 40 & 0,13 \\
\hline 64 & 70000 & 0,7 & 0,05 & 14 & 0,13 \\
\hline 65 & 20000 & 1,2 & 0,02 & 24 & 0,13 \\
\hline 66 & 260000 & 1,1 & 0,28 & 21 & 0,13 \\
\hline 67 & 460000 & 0,7 & 0,33 & 14 & 0,13 \\
\hline 68 & 240000 & 0,5 & 0,11 & 9 & 0,12 \\
\hline 69 & 300000 & n.a. & n.a. & n.a. & 0,11 \\
\hline 70 & 150000 & 0,9 & 0,14 & 18 & 0,07 \\
\hline 71 & 60000 & 1,9 & 0,12 & 39 & 0,12 \\
\hline 72 & 130000 & 1,1 & 0,14 & 21 & 0,10 \\
\hline 73 & 30000 & 1,1 & 0,03 & 22 & 0,09 \\
\hline 74 & 30000 & 0,7 & 0,02 & 14 & 0,05 \\
\hline 75 & 120000 & n.a. & n.a. & n.a. & 0,05 \\
\hline 76 & 140000 & n.a. & n.a. & n.a. & 0,10 \\
\hline 77 & 30000 & n.a. & n.a. & n.a. & 0,08 \\
\hline 78 & n.a. & n.a. & n.a. & n.a. & n.a. \\
\hline 79 & 90000 & 1,2 & 0,10 & 29 & 0,13 \\
\hline 80 & 250000 & 1,0 & 0,26 & 21 & 0,12 \\
\hline 81 & 320000 & 2,0 & 0,62 & 39 & 0,13 \\
\hline 82 & 330000 & 1,6 & 0,51 & 31 & 0,10 \\
\hline 83 & 320000 & 1,2 & 0,37 & 23 & 0,12 \\
\hline 84 & 350000 & 1,3 & 0,47 & 27 & 0,12 \\
\hline 85 & 400000 & 1,6 & 0,63 & 31 & 0,12 \\
\hline 86 & 380000 & 1,3 & 0,48 & 25 & 0,12 \\
\hline
\end{tabular}


Bal oldali hullámtéri területegységek főbb jellemzői

\begin{tabular}{|c|c|c|c|c|c|}
\hline $\begin{array}{l}\text { Terület- } \\
\text { egység } \\
\text { száma }\end{array}$ & $\begin{array}{c}\text { Terület } \\
\left(\mathbf{m}^{2}\right)\end{array}$ & $\begin{array}{c}\text { Hordalék } \\
\text { vastagsága } \\
\text { (m) }\end{array}$ & $\begin{array}{l}\text { Hordalék } \\
\text { térfogata } \\
\left(\mathbf{m i l l i o ́} \mathbf{~ m}^{3}\right)\end{array}$ & $\begin{array}{c}\text { Vízszállító- } \\
\text { képesség } \\
\text { csökkenése } \\
(\%)\end{array}$ & $\begin{array}{l}\text { Növényzeti } \\
\text { érdesség (n) }\end{array}$ \\
\hline 1 & 80000 & 0,7 & 0,06 & 14 & 0,11 \\
\hline 2 & 260000 & 0,61 & 0,16 & 12 & 0,12 \\
\hline 3 & 260000 & 0,82 & 0,21 & 16 & 0,12 \\
\hline 4 & 580000 & 0,46 & 0,27 & 9 & 0,10 \\
\hline 5 & 490000 & 0,43 & 0,21 & 9 & 0,10 \\
\hline 6 & 640000 & 0,05 & 0,03 & 1 & 0,12 \\
\hline 7 & 530000 & 0,01 & 0,01 & 0 & 0,11 \\
\hline 8 & 300000 & 0,6 & 0,18 & 12 & 0,13 \\
\hline 9 & 150000 & 1,1 & 0,16 & 21 & 0,13 \\
\hline 10 & 420000 & 2,0 & 0,83 & 39 & 0,12 \\
\hline 11 & 680000 & 1,3 & 0,86 & 25 & 0,13 \\
\hline 12 & 690000 & 1,0 & 0,68 & 20 & 0,12 \\
\hline 13 & 610000 & 0,9 & 0,56 & 18 & 0,12 \\
\hline 14 & 510000 & n.a. & n.a. & n.a. & n.a. \\
\hline 15 & 560000 & 0,6 & 0,32 & 12 & 0,11 \\
\hline 16 & 600000 & 0,4 & 0,26 & 9 & 0,08 \\
\hline 17 & 550000 & 0,6 & 0,34 & 12 & 0,11 \\
\hline 18 & 560000 & 0,5 & 0,25 & 9 & 0,11 \\
\hline 19 & 360000 & n.a. & n.a. & n.a. & n.a. \\
\hline 20 & 130000 & 0,41 & 0,05 & 8 & 0,12 \\
\hline 21 & 230000 & 1,37 & 0,32 & 27 & 0,11 \\
\hline 22 & 670000 & 1,76 & 1,18 & 35 & 0,09 \\
\hline 23 & 430000 & 0,66 & 0,28 & 13 & 0,12 \\
\hline 24 & 370000 & 0,63 & 0,23 & 13 & 0,13 \\
\hline 25 & 230000 & 0,75 & 0,17 & 15 & 0,12 \\
\hline 26 & 140000 & 1,32 & 0,18 & 26 & 0,13 \\
\hline 27 & 310000 & 0,89 & 0,28 & 18 & 0,13 \\
\hline 28 & 120000 & 1,68 & 0,20 & 34 & 0,13 \\
\hline 29 & 470000 & 1,76 & 0,83 & 35 & 0,13 \\
\hline 30 & 680000 & 1,43 & 0,97 & 29 & 0,10 \\
\hline 31 & 2470000 & 1,2 & 2,96 & 24 & 0,08 \\
\hline 32 & 1700000 & 0,23 & 0,39 & 5 & 0,09 \\
\hline 33 & 900000 & 0,63 & 0,57 & 13 & 0,10 \\
\hline 34 & 700000 & 1,07 & 0,75 & 21 & 0,12 \\
\hline 35 & 330000 & 1,18 & 0,39 & 24 & 0,13 \\
\hline 36 & 130000 & 0,66 & 0,09 & 13 & 0,13 \\
\hline 37 & 110000 & n.a. & n.a. & n.a. & n.a. \\
\hline 38 & 350000 & 2,2 & 0,77 & 44 & 0,10 \\
\hline 39 & 570000 & 1,66 & 0,95 & 33 & 0,09 \\
\hline 40 & 430000 & 0,12 & 0,05 & 2 & 0,12 \\
\hline 41 & 310000 & 2,03 & 0,63 & 41 & 0,12 \\
\hline 42 & 770000 & 0,51 & 0,39 & 10 & 0,11 \\
\hline 43 & 400000 & 2,11 & 0,84 & 42 & 0,09 \\
\hline 44 & 1060000 & 1 & 1,06 & 20 & 0,10 \\
\hline
\end{tabular}




\begin{tabular}{|c|c|c|c|c|c|}
\hline 45 & 1660000 & 1,4 & 2,32 & 28 & 0,11 \\
\hline 46 & 1530000 & 1,57 & 2,40 & 31 & 0,10 \\
\hline 47 & 1280000 & 2,64 & 3,38 & 53 & 0,09 \\
\hline 48 & 1510000 & 0,75 & 1,13 & 15 & 0,11 \\
\hline 49 & 2130000 & 1,19 & 2,53 & 24 & 0,12 \\
\hline 50 & 2940000 & 1,16 & 3,41 & 23 & 0,09 \\
\hline 51 & 3900000 & 1,58 & 6,16 & 32 & 0,10 \\
\hline 52 & 3130000 & 1,3 & 4,07 & 26 & 0,09 \\
\hline 53 & 2610000 & 0,8 & 2,09 & 16 & 0,10 \\
\hline 54 & 810000 & 0,59 & 0,48 & 12 & 0,12 \\
\hline 55 & 270000 & 1,12 & 0,30 & 22 & 0,13 \\
\hline 56 & 190000 & 1,42 & 0,27 & 28 & 0,12 \\
\hline 57 & 110000 & 1,82 & 0,20 & 36 & 0,13 \\
\hline 58 & 210000 & 1,68 & 0,35 & 34 & 0,13 \\
\hline 59 & 460000 & 1,22 & 0,56 & 24 & 0,12 \\
\hline 60 & 230000 & 1,12 & 0,26 & 22 & 0,12 \\
\hline 61 & 980000 & 1,42 & 1,39 & 28 & 0,13 \\
\hline 62 & 280000 & 1,53 & 0,43 & 31 & 0,13 \\
\hline 63 & 400000 & 1,78 & 0,71 & 36 & 0,13 \\
\hline 64 & 480000 & 2,13 & 1,02 & 43 & 0,12 \\
\hline 65 & 530000 & 1,63 & 0,86 & 33 & 0,12 \\
\hline 66 & 320000 & 1,05 & 0,34 & 21 & 0,12 \\
\hline 67 & 500000 & 0,78 & 0,39 & 16 & 0,11 \\
\hline 68 & 290000 & 0,81 & 0,23 & 16 & 0,12 \\
\hline 69 & 250000 & 0,73 & 0,18 & 15 & 0,13 \\
\hline 70 & 470000 & 1,1 & 0,54 & 23 & 0,12 \\
\hline 71 & 580000 & 1,3 & 0,74 & 25 & 0,12 \\
\hline 72 & 490000 & 0,9 & 0,42 & 17 & 0,13 \\
\hline 73 & 500000 & 0,5 & 0,27 & 11 & 0,12 \\
\hline 74 & 240000 & 0,8 & 0,18 & 15 & 0,11 \\
\hline 75 & 160000 & 1,27 & 0,20 & 25 & 0,13 \\
\hline 76 & 70000 & n.a. & n.a. & n.a. & 0,13 \\
\hline 77 & 160000 & n.a. & n.a. & n.a. & 0,06 \\
\hline 78 & 150000 & n.a. & n.a. & n.a. & 0,12 \\
\hline 79 & 30000 & 1,5 & 0,04 & 30 & 0,12 \\
\hline 80 & n.a. & n.a. & n.a. & n.a. & n.a. \\
\hline 81 & 52877,25 & 2,0 & 0,11 & 40 & 0,07 \\
\hline 82 & 100000 & 2,1 & 0,21 & 41 & 0,09 \\
\hline 83 & 200000 & 1,45 & 0,29 & 29 & 0,12 \\
\hline 84 & 160000 & 1,43 & 0,23 & 29 & 0,13 \\
\hline 85 & 69924,5 & 2,21 & 0,15 & 44 & 0,13 \\
\hline 86 & 130000 & 1,99 & 0,26 & 40 & 0,12 \\
\hline
\end{tabular}

